Florida International University FIU Digital Commons

6-15-2009

\title{
Paleoenvironmental Reconstruction of Florida Bay, South Florida, Using Benthic Foraminifera
}

Jie Cheng

Florida International University, jchen010@fiu.edu

DOI: $10.25148 /$ etd.FI10041605

Follow this and additional works at: https://digitalcommons.fiu.edu/etd

Part of the Physical and Environmental Geography Commons

\section{Recommended Citation}

Cheng, Jie, "Paleoenvironmental Reconstruction of Florida Bay, South Florida, Using Benthic Foraminifera" (2009). FIU Electronic Theses and Dissertations. 179.

https://digitalcommons.fiu.edu/etd/179

This work is brought to you for free and open access by the University Graduate School at FIU Digital Commons. It has been accepted for inclusion in FIU Electronic Theses and Dissertations by an authorized administrator of FIU Digital Commons. For more information, please contact dcc@fiu.edu. 


\section{FLORIDA INTERNATIONAL UNIVERSITY}

Miami, Florida

\section{PALEOENVIRONMENTAL RECONSTRUCTION OF FLORIDA BAY, SOUTH FLORIDA, USING BENTHIC FORAMINIFERA}

A dissertation submitted in partial fulfillment of the

requirements for the degree of

DOCTOR OF PHILOSOPHY

in

GEOSCIENCES

by

Jie Cheng

2010 
To: Dean Kenneth Furton

College of Arts and Sciences

This dissertation, written by Jie Cheng, and entitled Paleoenvironmental Reconstruction of Florida Bay, South Florida, Using Benthic Foraminifera, having been approved in respect to style and intellectual content, is referred to you for judgment.

We have read this dissertation and recommend that it be approved.

$\begin{array}{r}\text { William Anderson } \\ \hline \text { Evelyn Gaiser } \\ \hline \text { Rene Price } \\ \hline \text { Laurel Collins, Major Professor }\end{array}$

Date of Defense: June 15, 2009

The dissertation of Jie Cheng is approved.

Dean Kenneth Furton

College of Arts and Sciences

Interim Dean Kevin O'Shea

University Graduate School

Florida International University, 2010 


\section{ACKNOWLEDGMENTS}

Many people contributed to this study. I especially thank my advisor, Dr. Laurel Collins, for her unyielding support and encouragement through this process, as well as my committee members Dr. Evelyn Gaiser, Dr. Rene Price and Dr. William Anderson, whose advice and flexibility will not be forgotten. I also give thanks to Charles Holmes, U.S. Geological Survey, St. Petersburg, Florida, for directing collection of the cores and the ${ }^{210} \mathrm{~Pb}$ dating. Jim Fourqurean, Department of Biological Sciences, was helpful in discussions of the seagrasses of Florida Bay. NSF grant no. EAR-0126024 to L. Collins and others supported the core collection, dating of samples, and my graduate student support. Finally, I would like to thank the University Graduate School, which provides me the Dissertation Year Fellowship to support my research. 


\title{
ABSTRACT OF THE DISSERTATION \\ PALEOENVIRONMENTAL RECONSTRUCTION OF FLORIDA BAY, SOUTH FLORIDA, USING BENTHIC FORAMINIFERA
}

\author{
by
}

\section{Jie Cheng}

Florida International University, 2009

Miami, Florida

\section{Professor Laurel Collins, Major Professor}

Efforts that are underway to rehabilitate the Florida Bay ecosystem to a more natural state are best guided by a comprehensive understanding of the natural versus humaninduced variability that has existed within the ecosystem. Benthic foraminifera, which are well-known paleoenvironmental indicators, were identified in 203 sediment samples from six sediment cores taken from Florida Bay, and analyzed to understand the environmental variability through anthropogenically unaltered and altered periods. In this research, taxa serving as indicators of (1) seagrass abundance (which is correlated with water quality), (2) salinity, and (3) general habitat change, were studied in detail over the past 120 years, and more generally over the past $\sim 4000$ years. Historical seagrass abundance was reconstructed with the proportions of species that prefer living attached to seagrass blades over other substrates. Historical salinity trends were determined by analyzing brackish versus marine faunas, which were defined based on species' salinity preferences. Statistical methods including cluster analysis, discriminant analysis, analysis of variance and Fisher's $\alpha$ were used to analyze trends in the data. The changes in seagrass abundance and salinity over the last $\sim 120$ years are attributed to anthropogenic activities 
such as construction of the Flagler Railroad from the mainland to the Florida Keys, the Tamiami Trail that stretches from the east to west coast, and canals and levees in south Florida, as well as natural events such as droughts and increased rainfall from hurricanes. Longer term changes (over $\sim 4000$ years) in seagrass abundance and salinity are mostly related to sea level changes. Since seawater entered the Florida Bay area around $\sim 4000$ years ago, only one probable sea level drop occurring around $\sim 3000$ years was identified. 


\section{TABLE OF CONTENTS}

CHAPTER

PAGE

1. INTRODUCTION

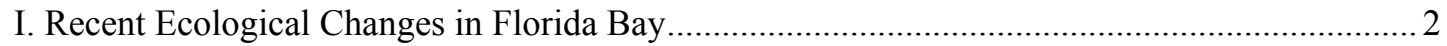

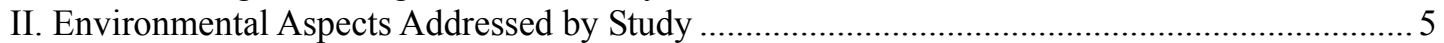

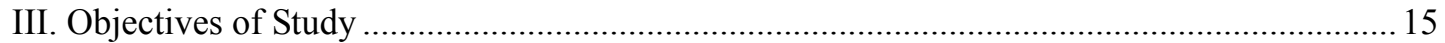

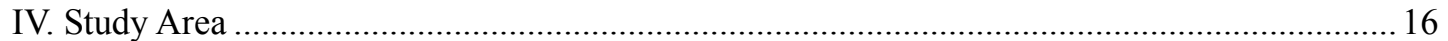

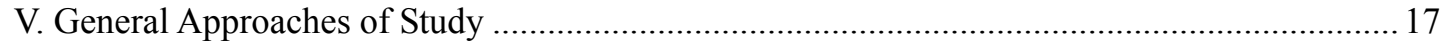

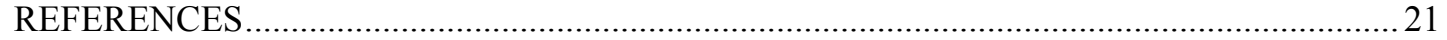

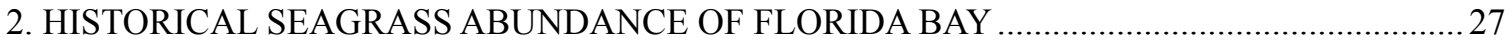

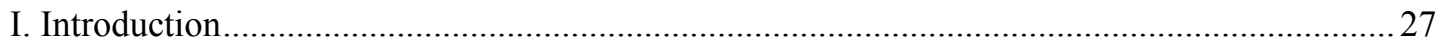

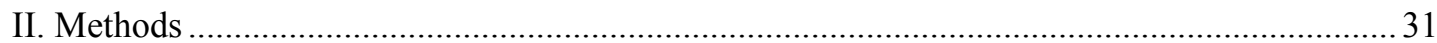

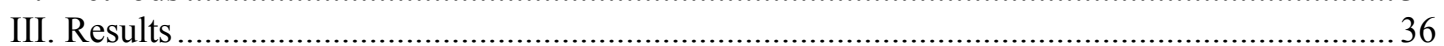

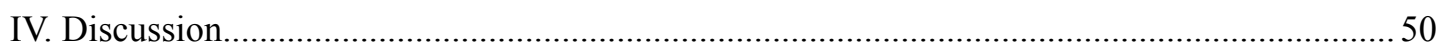

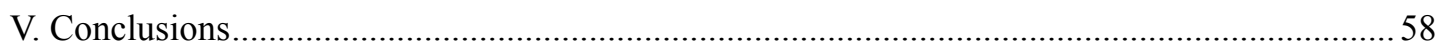

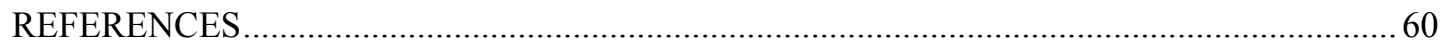

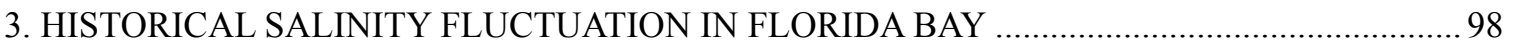

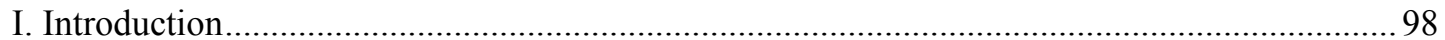

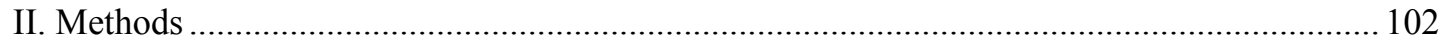

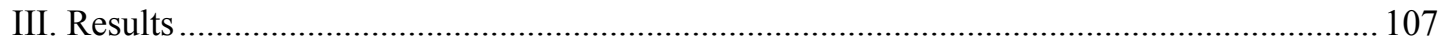

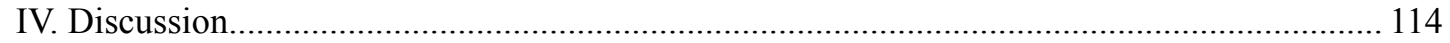

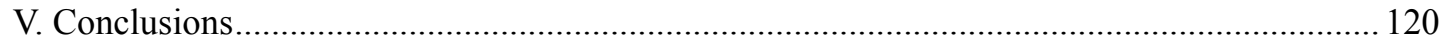

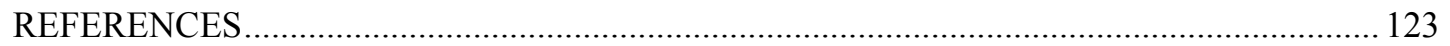

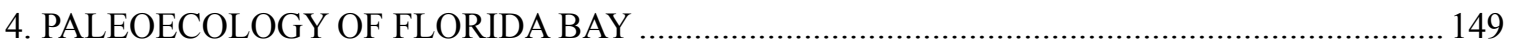

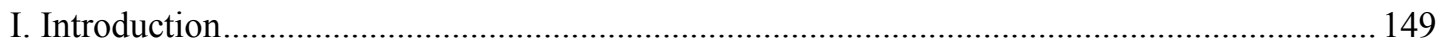

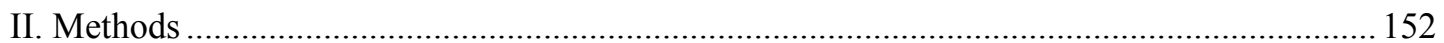

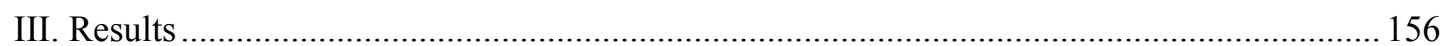

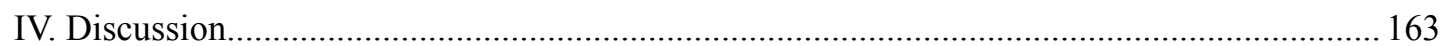

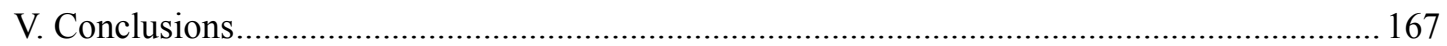

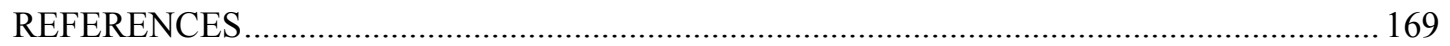

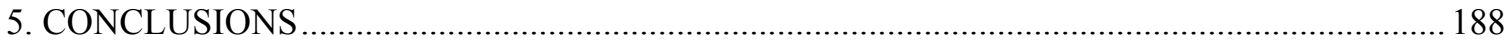

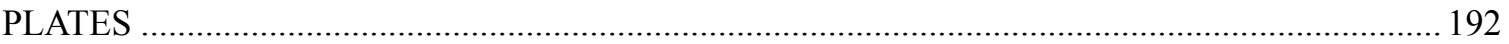

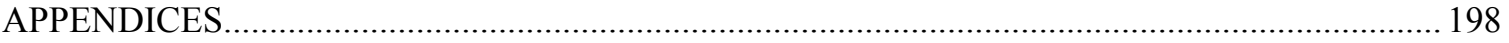

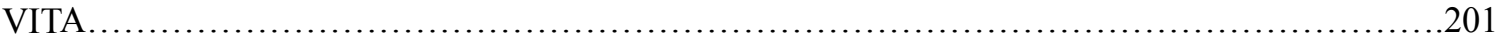




\section{LIST OF TABLES}

TABLE

PAGE

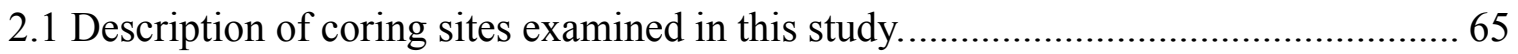

2.2 Radiocarbon dates for Trout Cove and Ninemile Bank ........................................ 66

2.3 Anthropogenic and environmental events affecting freshwater flow in South Florida

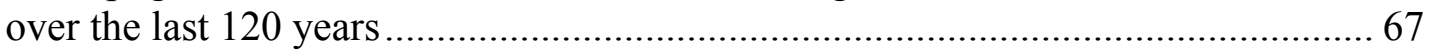

2.4 Time intervals defined by land-use activities and the recent seagrass dieoff............. 68

2.5 Sedimentation accumulation rates and maximum extent downcore of ${ }^{210} \mathrm{~Pb}$ ages for the six studied cores 69

2.6 General ecology of predominantly seagrass-associated benthic foraminifera 70

3.1 Description of coring sites examined in this study........................................ 128

3.2 Radiocarbon dates for Trout Cove and Ninemile Bank. ....................................... 129

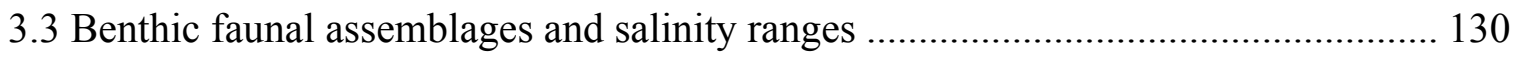

3.4 Time intervals defined by land-use activities and documented environmental changes. 131

4.1 Description of coring sites examined in this study.......................................... 174

4.2 Radiocarbon dates for Trout Cove and Ninemile Bank. ..................................... 175

4.3 Two ecologically defined foraminiferal associations and their habitats ................. 176

4.4 General ecology of common species found in Florida Bay ................................. 177 


\section{LIST OF FIGURES}

FIGURE

PAGE

2.1 Map of Florida Bay showing four coring sites................................................. 72

2.2 Percentages of seagrass-associated benthic foraminifera in Bob Allen Bank Core \#0206122, after 1970, and CONISS clustering................................................ 73

2.3 Percentages of seagrass-associated benthic foraminifera in Bob Allen Bank Core \#0206124, after 1970, and CONISS clustering.................................................. 74

2.4 Percentages of seagrass-associated benthic foraminifera in Russell Key Core \#0206125, after 1970, and CONISS clustering.............................................. 75

2.5 Percentages of seagrass-associated benthic foraminifera in Russell Key Core \#0206127, after 1970, and CONISS clustering................................................ 76

2.6 Percentages of seagrass-associated benthic foraminifera in Ninemile Bank Core \#0208134, after 1970, and CONISS clustering.............................................. 77

2.7 Percentages of seagrass-associated benthic foraminifera in Trout Cove Core \#02061211, after 1970, and CONISS clustering .............................................. 78

2.8 Trends in percentages of seagrass-associated benthic foraminifera between 1970 and 2001, all examined cores. 79

2.9 Discriminant analysis showing three separate intervals, Bob Allen Bank and Russell Key cores.

2.10 Percentages of seagrass-associated foraminifera in Bob Allen Bank Core \#0206122, 1880-2001, and CONISS clustering............................................................ 81

2.11 ANOVA of Bob Allen core \#0206122, last 120 years......................................... 82

2.12 Percentages of seagrass-associated foraminifera in Bob Allen Bank Core \#0206124,

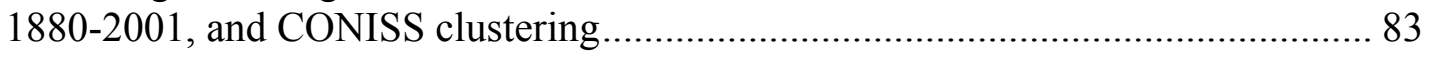

2.13 ANOVA of Bob Allen Core \#0206124, last 120 years......................................... 84

2.14 Percentages of seagrass-associated foraminifera in Russell Key Core \#0206125,

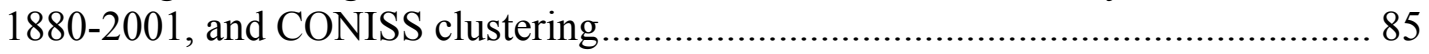

2.15 ANOVA of Russell Key Core \#0206125, last 120 years...................................... 86 
2.16 Percentages of seagrass-associated foraminifera in Russell Key Core \#0206127, 1938-2001, and CONISS clustering. 87

2.17 ANOVA of Russell Key Core \#0205127, last 120 years.......................................... 88

2.18 Percentages of seagrass-associated foraminifera in Ninemile Bank Core \#0208134,

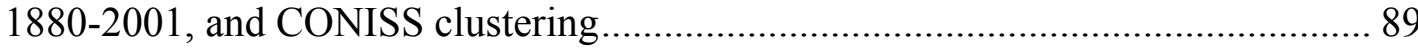

2.19 ANOVA of Ninemile Bank Core \#0208134, last 120 years..................................... 90

2.20 Percentages of seagrass-associated foraminifera in Trout Cove Core \#02061211, 1880-1994, and CONISS clustering.

2.21 ANOVA of Trout Cove Core \#02061211, last 120 years. ........................................ 92

2.22 Total percentages of seagrass-associated foraminifera in all cores for $1880-2001 \ldots . .92$

2.23 Discriminant Analysis on all cores for the two time intervals. 94

2.24 Percentages of seagrass-associated foraminifera in Ninemile Bank Core \#0208134. 95

2.25 Percentages of seagrass-associated foraminifera in Ninemile Bank Core \#0208134,

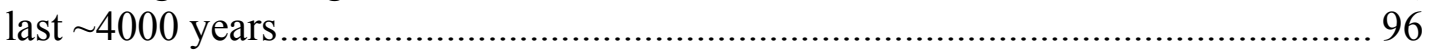

2.26 ANOVA on all studied samples from Ninemile Bank Core \#0208134 .................... 97

3.1 Map of Florida Bay showing the four coring sites.............................................. 132

3.2 Percentages of most abundant benthic foraminifera in Bob Allen Bank Core \#0206122 132

3.3 ANOVA for Bob Allen Bank Core \#0206122 ..................................133

3.4 Percentages of the most abundant benthic foraminifera in Bob Allen Bank Core $\# 0206124$ 134

3.5 ANOVA for Bob Allen Bank Core \#0206124...................................135

3.6 Percentages of the marine and brackish faunas, last 120 years............................... 137

3.7 Percentages of the most abundant benthic foraminifera in Russell Key Core $\# 0206125$ 
3.9 Percentages of the most abundant benthic foraminifera in Russell Key Core \#0206127

3.10 ANOVA for Russell Key Core \#0206127.................................. 140

3.11 Percentages of the most abundant benthic foraminifera in Ninemile Bank Core \#0208134 141

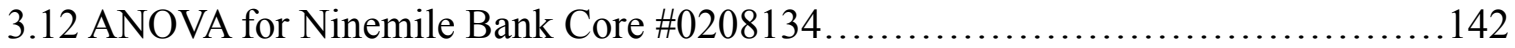

3.13 Percentages of the most abundant benthic foraminiferal in Trout Cove Core \#02061211

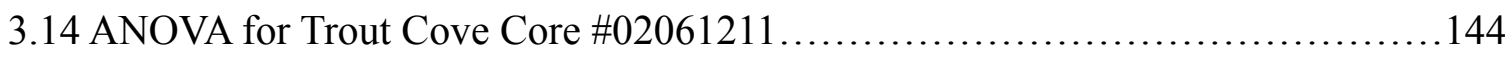

3.15 Discriminant analysis of samples from the four areas .................................. 146

3.16 Percentages of the most abundant brackish and marine taxa in Ninemile Bank Core $\# 0208134$

3.17 Percentages of marine fauna in Ninemile Bank core over the last $\sim 4,000$ years .... 148

4.1 Map of Florida Bay showing the four coring sites......................................... 178

4.2 Percentages of common benthic foraminifera from Bob Allen Bank Core \#0206122,

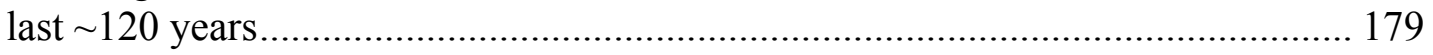

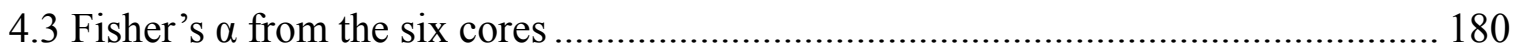

4.4 Percentages of common benthic foraminifera from Bob Allen Bank Core \#0206124,

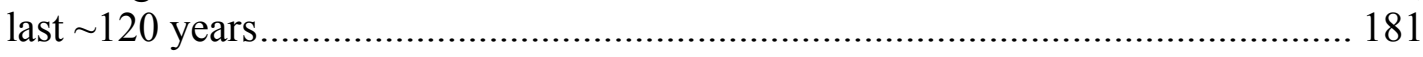

4.5 Percentages of common benthic foraminifera from Russell Key Core \#0206125, last $\sim 120$ years 182

4.6 Percentages of common benthic foraminifera from Russell Key Core \#0206127, last $\sim 80$ years 183

4.7 Percentages of common benthic foraminifera from Trout Cove Core \#02061211, last 1200 years 184

4.8 Percentages of common benthic foraminifera from Ninemile Bank Core \#0208134, last $\sim 4000$ years. 185

4.9 Fisher's $\alpha$ from Ninemile Bank, last $\sim 4000$ years 186 
4.10 Cluster analysis of all studied samples from Ninemile Bank and Trout Cove........ 187 


\section{LIST OF PLATES}

PLATE

PAGE

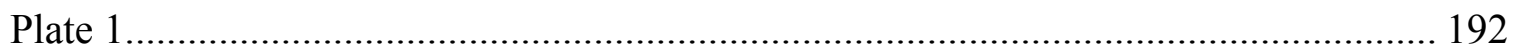

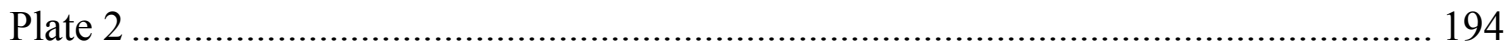

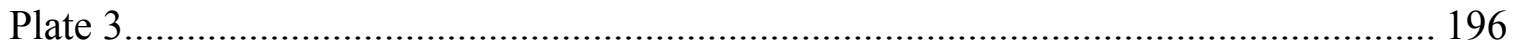




\section{LIST OF APPENDICES}

APPENDICES

PAGE

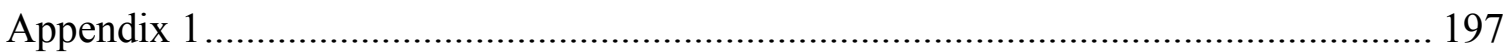

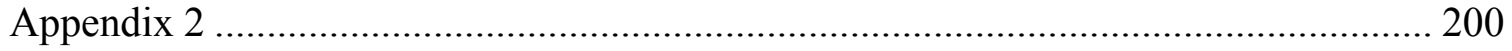




\section{CHAPTER 1}

\section{INTRODUCTION}

Dramatic ecological changes occurring in Florida Bay starting in 1987 focused the attention of the public on the contributing factors (Boyer and Fourqurean, 1997). These changes included seagrass die-off, algal blooms and increased turbidity. Since then, scientists have been trying to restore Florida Bay to its historic condition, but what is not clear is what an anthropogenically unaltered Florida Bay would look like (Fourqurean and Robblee, 1999). This study examines three paleoenvironmental aspects of Florida Bay: seagrass abundance, salinity and habitat change. One of the primary purposes of this research is to trace historic seagrass abundances, an excellent water quality indicator (Durako et al., 2002), over the past 4,000 years, to assess its natural variability. The relative abundances of benthic foraminifera, well-known paleoecologic indicators that are contained in marine-influenced sediments, are used to identify these and other environmental changes.

Seagrass abundance is also affected by salinity. Another main purpose of this research is to study salinity fluctuation through the past 4,000 years. Construction of levees and canals in the past century to divert freshwater to the Atlantic Ocean and Gulf of Mexico to prevent flooding greatly reduced the water flow into the Everglades and its adjacent Florida Bay, and led to great changes in salinity in Florida Bay. Therefore, documenting historical trends in salinity variations that occurred before anthropogenic influences may help us understand what the natural conditions were. 
Besides these concerns about more recent ecological changes, scientists are interested in long-term changes in the habitat, including sea level, over the past 4000 years. Located on a relative stable platform, Florida Bay has long been regarded as a good location to study sea level fluctuation, which controls in part larger habitat changes. The third main purpose of this research is to study the paleohabitats of Florida Bay.

\section{Recent Ecological Changes in Florida Bay}

The ecosystem of Florida Bay includes marginal freshwater and saltwater wetlands and intertidal and offshore marine communities (Lidz and Rose, 1989). The water column is generally oligotrophic with low phytoplankton biomass (Fourqurean et al., 1993). The hard-bottom areas of Florida Bay are partially occupied by seagrass, corals and sponges. Other wildlife, including dolphins, manatees, American crocodiles, bald eagles, ospreys, roseate spoonbills, and many wading birds also select the Bay as a home (Fourqurean and Robblee, 1999).

Until recently, Florida Bay was known for its clear water, lush seagrass beds and outstanding fishing. Beginning in the 1980s, dramatic ecological changes have happened to the bay and the adjacent Everglades, including sustained algal blooms, widespread death of seagrass beds and a declining number of shellfish and sponges (Boyer and Fourqurean, 1997). Osprey populations, for instance, have declined about $50 \%$ across Florida Bay because of low food supply and poor habitat quality (McIvor et al., 1994; Fourqurean and Robblee, 1999). Algal blooms (Philips and Badylak, 1996) and increased sediment resuspension may have led to an increase in light attenuation, resulting in less light reaching the bottom, which eventually had a negative impact on the benthic flora 
and fauna. Blooms of cyanobacteria and algae have been cited as the causes for a mass mortality of sponges (Butler et al., 1995; Zieman et al., 1999), which provide the primary habitat for the juvenile spiny lobster, Panulirus argus, one of the most valuable fisheries species in the Florida Keys. The pink shrimp fishery, the largest commercial fishery in Florida (Fourqurean and Robblee, 1999), declined to historic lows at the end of the 1980's, roughly coincident with the seagrass die-off in Florida Bay (Fourqurean and Robblee, 1999). The number of wading birds as well as some endangered species such as bald eagles, manatees, crocodiles, and sea turtles also declined as a result of the die-off in seagrass, which plays an important role as a shelter for numerous species (Hall et al., 1999).

Recognizing these perturbations to the natural system, the Everglades Forever Act was passed in 1994. The Florida and federal governments are currently faced with water- and land-use management decisions related to the restoration, mediation and monitoring of South Florida ecosystems (Ishman et al., 1997). In response to this, several organizations such as the U.S. Geological Survey, National Oceanic and Atmospheric Administration, and National Park Service, united to try to restore the ecosystems of Southern Florida. Currently, efforts are underway to rehabilitate the Florida Bay ecosystem to its natural state, but this should be guided by a comprehensive understanding of the natural versus human-induced variability that has existed within the ecosystem.

Anthropogenic effects on Florida Bay include human-induced pollution and freshwater management. Nutrient enrichment of nearshore waters has been a major issue worldwide, and in South Florida, nutrients produced by humans enter Florida Bay from marine sources and from the canals. The annual loading of nitrogen and phosphorous is variable 
and largely controlled by the volume of water flowing into the bay. Water input from the Everglades to Florida Bay generally contains a high ratio of total nitrogen (TN) to total phosphorus (TP) (Rudnick et al., 1999). Because Everglades National Park (ENP) is phosphorus-deficient, TP and dissolved inorganic nitrogen are rapidly removed from the water by organisms in the Everglades. In contrast, TN, which is generally $95 \%$ organic $\mathrm{N}$, remains relatively constant as it passes through the Everglades. The TN concentration can only be lowered in areas with relatively high phosphorus availability, such as the wetlands in the north part of ENP and in the mangrove streams of western ENP. It was estimated that increasing the freshwater flow into the Everglades and Florida Bay would also increase TN concentration. However, from the data on the nutrient budget for Florida Bay, the nutrient (TN and TP) inputs from Gulf of Mexico greatly exceed inputs from ENP, as well as inputs from the atmosphere and the Florida Keys (Rudnick et al., 1999). It has been estimated that less than $3 \%$ of phosphorus and less than $12 \%$ of nitrogen are contributed by freshwater from the Everglades (Rudnick et al., 1999).

Freshwater flow into the Everglades and adjacent Florida Bay has been greatly altered by its diversion for agriculture and urban use, and the construction of an extensive system of canals and levees for flood control (Light and Dineen, 1994). During the early nineteenth century, a major perturbation to the Everglades was the construction of the Tamiami Trail, now a highway stretching across the entire southern tip of the peninsula, which blocked most freshwater flow into the southern Everglades except the Shark River Slough (McIvor et al., 1994). Canals and levee systems were built as protection from flooding, but it was not until the 1940's when several hurricanes struck Florida and claimed over thousands of lives that the state government initiated a program of building 
the canal network for water management (Light and Dineen, 1994). Water flow originally passing through Shark River Slough and Taylor Slough, primary freshwater sources for Florida Bay, was then diverted to the Gulf of Mexico and the Atlantic Ocean.

Modification has since been made by water management control agencies to try to increase water flow into the bay to improve the habitat for commercially important fish and other organisms such as wading birds (Montague and Ley, 1993).

In addition to anthropogenic influences, climatic change has also played a role. Precipitation varies by almost $40 \%$ in Florida during the Atlantic Multidecadal Oscillation (AMO) warm phases and AMO cool phases (Enfield et al., 2001). More numerous El Niño (ENSO) years have been related to increased precipitation in southern Florida (Winkler et al., 1999). More frequent visiting hurricanes during the first half of the $20^{\text {th }}$ century were also reported to have had some impact on the environments of Florida Bay (Cronin et al., 2001).

\section{Environmental Aspects Addressed by Study}

\section{Seagrass Abundance of Florida Bay}

Seagrasses are characteristic of shallow coastal waters worldwide. They help stabilize the seafloor sediment and provide shelter for a variety of marine animals. Few areas contain meadows as well developed as those found in Florida Bay, which contains one of the world's most extensive seagrass beds (ca. $1800 \mathrm{~km}^{2}$; Zieman et al., 1989). Three species of seagrasses, Syringodium filiforme (manatee grass), Halodule wrightii (shoal grass) and Thalassia testudinum (turtle grass), covered over $80 \%$ of the bottom of Florida Bay prior to the seagrass die-off that began in 1987 (Zieman et al., 1989) and ended 1994. 
Among them, T. testudinum is by far the most widespread and abundant seagrass species in Florida Bay and its distribution has changed little over the last decade (Hall et al., 1999). Two surveys made in 1984 and 1994 showed that over that time T. testudinum density and biomass declined significantly and its mean shoot density dropped by $22 \%$ (Hall et al., 1999). The two other seagrass species S. filiforme and H. wrightii suffered a similar decline of $93 \%$ and $92 \%$, respectively (Hall et al., 1999). Scientists estimated that over $40 \mathrm{~km}^{2}$ of seagrass beds were denuded, and an additional $230 \mathrm{~km}^{2}$ were affected to a lesser degree (Boyer et al., 1999; Zieman et al., 1999). Besides Florida Bay, other estuaries in Florida, such as Tampa Bay and Charlotte Harbor, also lost over 20\% of their seagrasses compared to previous levels (Zieman et al., 1989; Tomasko et al., 1996).

The causes of seagrass mortality are still not well understood ( Zieman et al., 1999), but stresses induced by hypersalinity, elevated temperature, sulfide toxicity and hypoxia are believed to play important roles. The studies of Montague and Ley (1993) and Lirman and Cropper (2003) concluded the following: $H$. wrightii is broadly euryhaline; $S$. filiforme is the most susceptible seagrass species and maximum growth rates occurred at 25 psu (pratical salinity units) and dropped dramatically at higher or lower values; and $T$. testudinum prefers to live in the nearshore with the salinity range between 30 psu and 40 psu. McMillan and Moseley (1967) also reported that S. filiforme and T. testudinum stopped growing when salinity was around 45-60 psu. Unlike the other two types, $H$. wrightii has a high tolerance to salinity variation (Montague and Ley, 1993). It has the ability to survive near the canal where salinity may be greatly affected by freshwater inputs (Montague and Ley, 1993), and be able to continue to grow in the environment with extremely high values of salinity up to $72 \mathrm{psu}$ (McMillan and Moseley, 1967). 
Apparently, the hypersalinity caused by a multiyear drought during the late 1980's and also long-term water management have stressed T. testudinum and S. filiforme, but the effects on $H$. wrightii have not been large. Salinity variation cannot account for the entire pattern of initial seagrass die-off and the subsequent environmental changes in Florida Bay. Other evidence shows that sulfide toxicity and hypoxia played vital roles as well in the initiation of the seagrass die-off (Carlson et al., 1994). Besides these factors, extremely high temperatures, imbalance in the ratio of photosynthesis to respiration, eutrophication of the water and lowered water clarity may further stress seagrasses (Zieman et al., 1999).

As a result of the 1980's seagrass die-off, the Florida Bay ecosystem was changed substantially in the 1990s. The water that had been clear in western and central Florida Bay became turbid when the nutrients were released from decaying seagrass biomass, which may have led to decreased light attenuation in the bottom water and two related consequences: algal blooms and sediment resuspension (Zieman et al., 1999; Hall et al., 1999). This situation may, in turn, have caused more seagrass to die. As the shelter for a great many species in Florida Bay, future declines in seagrass habitat or changes in the species composition of seagrasses within Florida Bay could have serious consequences for the economy and ecology of South Florida (Hall et al., 1999).

Seagrass has long been regarded as an excellent water quality indicator because of its sensitivity to salinity variation and eutrophication (Lirman and Cropper, 2003). Thus, indications of seagrass abundance can be used as a measure of water clarity and quality in the past. In this study, because seagrass is rarely fossilized, benthic foraminifera associated with seagrass are used to reconstruct the history of variation in seagrass 
abundance. Although the co-evolution between seagrass and benthic foraminifera is still poorly understood (Sen Gupta, 1999), their associations are widely reported in the literature. The best known associations of foraminifera with seagrass are those of the Soritidae (Bock, 1967), porcellaneous foraminifera that generally have dinoflagellate or chlorophyte endosymbionts (Sen Gupta, 1999). For example, some large soritid species such as Archaias compressus, Articulina mucronata, Sorites marginalis, S. orbiculus and Parasorites orbitoloides, which prefer to live on seagrass more than in the sediments (Bock, 1967), should be good indicators for seagrass abundance. Over $95 \%$ of foraminiferal species living in seagrass or macroalgal substrates are permanently or temporarily motile (Langer, 1993).

\section{Salinity Fluctuation}

Salinity varies from western to eastern Florida Bay, ranging from fresh to brackish close to the Everglades-Florida Bay interface, to normal marine values close to the western and southern boundaries where water is exchanged with the Gulf of Mexico and the Atlantic Ocean (Lidz and Rose, 1989). In eastern Florida Bay, salinity has the greatest variation because it is very sensitive to the operations of the South Florida Water Management District, a state governmental body which determines the timing and distribution of freshwater flows through canal systems to the eastern bay (McIvor et al., 1994). Therefore, depending on precipitation and seasonal variations in freshwater runoff into the bay, salinity ranges from 6 to $70 \mathrm{psu}$, the highest fluctuations happening in the northeastern part of the bay (Lidz and Rose, 1989). Central Florida Bay has a long history of hypersaline conditions because direct fresh water flow from the Everglades to this area 
is limited. A salinity value of 70 psu was once recorded in the 1950's (Light and Dineen, 1994) and again in the late 1980's (Fourqurean and Robblee, 1999). Restriction of water circulation and high evaporation rates may also account for the high value (Price et al., 2008). Near the northern coastline, the water is frequently turbid and appears to be influenced by runoff from rivers along the southwest coast of Florida (Boyer et al., 1999). Southern Florida Bay is historically clearer than it is now (Fourqurean et al., 1993), and salinity in this region is similar to normal seawater (Fourqurean et al., 1993). Generally, in most of the bay, salinity is between 35 and 40 psu (Enos and Perkins, 1979). Also, large quantities of freshwater have been input to the bay with a widespread lowering of salinity levels immediately following hurricane events (Kelble et al., 2007).

Historically, salinity fluctuated throughout the whole $20^{\text {th }}$ century. Changes in salinity patterns during the last century are believed to be related to several anthropogenic activities: construction of the Flagler Railroad from 1905 to 1912; Tamiami Trail construction and the early canal and levee system between 1915 and 1928; water management practices starting around the 1940's (Brewster-Wingard and Ishman, 1999; Swart et al., 1999); and a multi-year drought from 1987 (Fourqurean and Robblee, 1999). In Florida Bay, the distribution of benthic foraminifera is primarily affected by salinity and temperature, and secondarily by waves and currents (Lidz and Rose, 1989). Approximately 50 foraminiferal species belonging to 32 genera and 20 families (Bock et al., 1971; Rose and Lidz, 1977; Steinker, 1977) have been reported to be common in Florida Bay. Numerous previous papers (Rose and Lidz, 1977; Lidz and Rose, 1989; Ishman et al., 1997; Hill et al., 2003) divided benthic foraminifera into three major ecological categories: brackish fauna (low salinity), marine fauna (normal marine salinity) 
and hypersaline fauna (above $45 \mathrm{psu}$ ). In general, the genera Ammonia, Elphidium and some agglutinated taxa such as Ammotium belong to the brackish fauna; and the genera such as Amphisteria, Archaias, Quinqueloculina and Triloculina prefer to live in an environment with higher salinity (Lidz and Rose, 1989). Normally, the composition of benthic foraminiferal assemblages changes with increasing salinity (Hill et al., 2003). For example, miliolids such as Quinqueloculina and Triloculina may reach their greatest diversity where the environment changes from normal estuarine to open ocean. For hypersaline environments, in most cases, only the miliolids are dominant so their appearance may also be an indicator for dry periods in this case (Hill et al., 2003). Like many other foraminiferal researchers, Ishman divided the Florida Bay foraminiferal assemblages into two ecological groups: brackish taxa, mainly Ammonia, Elphidium and Ammotium sp.; and the normal marine taxa Miliolinella, Quinqueloculina and Peneroplis (Brewster-Wingard and Ishman, 1999).

\section{Larger Scale Habitat Change}

The habitats of Florida Bay have been consistently changing for the past 4,000 years, since its initial flooding. The sequence proceeded through a freshwater and Evergladeslike environment, to a mangrove swamp and finally a shallow bay (Davies and Cohen, 1989). Sedimentologic evidence has indicated that with the rise of sea level, Florida Bay was gradually inundated until about 1500 years ago (Wanless and Tagett, 1989) when the eastern bay was finally covered by marine water. As a result of continuing changes in sea level and other environmental factors, the habitats of Florida Bay have been altered over time. Habitat changes are studied by analyzing the sedimentary record of benthic 
foraminiferal assemblages, which respond to changes in salinity, substratum types, temperatures and food supply. The results from six sediment cores taken in Florida Bay in this research are applied to an analysis of habitat changes, including sea level change, over the past 4000 years.

Before the Holocene sea-level transgression, the area that Florida Bay now occupies was an extension of the freshwater Everglades (Davies and Cohen, 1989). Around 4,000 years before present, sea level began to rise and inundate the area, and it was not until about 1,500 years ago that eastern Florida Bay was totally covered by marine water (Wanless and Tagett, 1989), which can be approved by the age of basal peats that accumulated in freshwater on the hard, limestone substratum. As seen in sediment cores, the basal peat consists of several subdivisions: (1) freshwater peat at the base, overlain by (2) transitional or brackish-water peat formed by buttonwood or red mangrove, and in turn overlain by (3) marginal marine peat formed only of mangroves (Enos, 1989). Carbon-14 dating has revealed that these freshwater peats were deposited around 3,500 to 5,000 years ago (Wanless and Tagett, 1989).

How sea level changed through the Holocene is still debated. Two different late Holocene sea level curves have been proposed by Shepard (1963) and Fairbridge (1976). Shepard (1963) proposed that sea level steadily rose throughout the Holocene. This theory is supported by several studies (Scholl et al., 1969; Wanless and Tagett, 1989; Gleason and Stone, 1994) of southwest Florida which focused on the age of mangrove peat deposits. In contrast, Fairbridge (1974) and others (Missimer, 1980; Walker et al., 1995; Froede, 2002) believed that the position of late Holocene sea level was higher than present based on evidence from beach ridges, barrier islands and archeological sites. 
Evidence from coral reefs (which only grow to just below the level of mean low tide) also suggested that sea level has varied since 6,000 years BP (Fairbridge, 1974). Four major regressions and transgressions were proposed (Fairbridge, 1974) leading to major changes in the geography of coastal Florida and the Everglades.

For distinguishing habitat change, two major foraminiferal associations are used: an Ammonia beccarii association for the mangrove environment, and a Quinqueloculina spp. association for the marine environment (Phleger, 1966; Lidz and Rose, 1989; Murray, 1991). Larger changes in the dominance of one of these associations indicate changes in habitat.

Generally, there are two types of vegetation in intertidal zones of wet coastal areas (Sen Gupta, 1999): salt marshes in temperate regions and mangrove swamps in the tropics. Marsh foraminifera, in particular, are relatively accurate sea level indicators since they have narrow ecological tolerances and narrow vertical ranges in the intertidal zone (Woodroffe et al., 2005). Scott et al. (2001) were the first to identify the limits and ranges of foraminiferal zones in salt marshes. A group of widespread agglutinated taxa is generally regarded as typical of coastal salt marshes. This group includes Ammotium, Miliammina, Trochammina, Arenoparrella and Tipotrocha (Sen Gupta, 1999). Most of these well-known marsh foraminifera also occur in mangrove swamps. Ammotium and Arenoparrella, in particular, also dominate mangrove assemblages in diverse areas, such as Trinidad (Saunders, 1958) and Florida (Brewster-Wingard and Ishman, 1999). Moreover, there may be remarkable similarity between mangrove foraminiferal assemblages from very different longitudes (Sen Gupta, 1999). Therefore, studies focusing on mangrove swamps and salt marshes in other temperate or tropic locations 
(Halfar and Ingle, 2003; Barbosa et al., 2005; Vance et al, 2006) are references for this study. Besides agglutinated species, other taxa such as Ammonia and Elphidium may constitute up to $80 \%$ of the total population in mangrove swamps (Lidz and Rose, 1989). Furthermore, large foraminifera like soritids are sparse or completely absent, and of the miliolids, only small amounts of Quinqueloculina, Miliolinella and Triloculina are occasionally present (usually less than $10 \%$; Lidz and Rose, 1989), probably due to the brackish environment of mangrove swamps. According to a recent study on modern mangrove swamps of Florida Bay, salinity varies from a median value of $7 \mathrm{psu}$ in the inner mangrove fringe to $15 \mathrm{psu}$ in the outer mangrove fringe (Boyer and Fourqurean, 1997).

Vertical zonations of modern foraminifera combined with plant communities have been used for reconstruction of ancient sea levels. For instance, Cann et al. (2002) separated foraminifera into four groups representing different vertical facies of the shoreline: shallow subtidal seagrass, intertidal environment, mangrove, and backstorm ridge and coastal lagoon environments. According to the changes in foraminiferal assemblage, Cann et al. (2002) determined how sea level fluctuated though time. Similar to this method, Horton et al. (2003) divided intertidal foraminiferal assemblages into three elevational zones: Zones I and II are dominated by agglutinated species, and Zone III is dominated by common calcareous species such as Ammonia and Elphidium. Furthermore, they also developed a functional model to calculate former sea levels based on the relationship between foraminiferal assemblage and elevation. Other studies (Halfar and Ingle, 2003; Gehrels et al., 2005; Woodroffe et al., 2005; Barbosa et al., 2005; Vance et al., 2006) also adopted similar ways of reconstructing sea level. When sea level 
transgression occurred, the mangrove swamp gradually disappeared and the foraminiferal assemblages slowly changed from the mangrove swamp fauna to the normal marine fauna. With the oscillation of sea level during the past 4000 years, the assemblage's composition also varied.

However, there are three major problems to determining past sea levels. (1) small-scale changes in sea level may be difficult to observe using foraminiferal assemblages because the small-scale changes may not significantly affect the foraminiferal assemblage composition. (2) Poor preservation of the foraminifera in mangrove swamps may alter the assemblage composition. Taphonomic processes (test transport, test dissolution, mechanical test breakage) may damage or even destroy foraminiferal tests (Culver, 1990). Mangrove swamps are generally considered to have low preservation potential in tropical areas (Sen Gupta, 1999) because the low- $\mathrm{pH}$ environment is not favorable for the preservation of calcareous foraminifera (Saunders, 1958). Some agglutinated foraminifera with thin walls, such as Miliammina obliqua, can rapidly dissolve upon burial (Saunders, 1958). (3) Information on vertical zonation trends in tropical environments is limited. Marsh foraminifera have been precisely and widely used to reconstruct sea level in temperate regions (Barbosa et al., 2005; Horton et al., 2005; Vance et al., 2006), and Scott and others (2001) even suggest that the same 8-10 species of marsh foraminifera are ubiquitous worldwide in the upper part of the intertidal zone. However, the distribution of foraminifera in tropical environments may be affected more strongly by other factors such as salinity and vegetation type. 


\section{Objectives of Study}

In order to investigate variability in the previous, natural state of Florida Bay, multiproxy methods such as diatoms (Huvane and Cooper, 2001), stable isotopes of oxygen and carbon (Swart et al., 1999) and foraminifera (Ishman et al., 1997) have been applied to sediment cores. In this study, benthic foraminifera are used. One advantage of selecting benthic foraminifera over most other microorganisms is their hard, outer calcareous test, which enables them to be preserved in the subsurface sedimentary record. Thus, benthic foraminifera are abundantly present in modern and ancient marine sediments, including those of Florida Bay. Although taphonomic processes may affect their preservation in the fossil record (see previous section), they are one of the best microfaunal groups for providing a proxy record of past marine and marginal marine environments (Murray, 2000).

There are three major objectives in this study, all using the sedimentary record of benthic foraminifera through the past $\sim 4000$ years:

(1) To understand how seagrass abundance has changed in the last 4,000 years. Some species of benthic foraminifera are more strongly associated with seagrass than with sediments. The higher the seagrass abundance is, the higher the percentage of these seagrass-associated foraminifera should be. This is the subject of Chapter 2, Historical Seagrass Abundance of Florida Bay.

(2) To determine how salinity fluctuated over the past 4,000 years. Based on modern salinity preferences, benthic foraminifera are categorized into two faunas: brackish and marine and faunas, and the proportions of these categories are tracked though time. This part of the study forms Chapter 3, Historical Salinity Fluctuation in Florida Bay. 
(3) To understand how overall habitats have varied in the past 4,000 years. As the habitat changed over geological time, the species composition of the foraminiferal assemblages in a particular place changed, e.g., from a marine to mangrove fauna. This is the subject of Chapter 4, Paleoecology of Florida Bay.

\section{Study Area}

Florida Bay is a shallow, triangular, subtropical bay located at the south end of the Florida peninsula and part of Everglades National Park (ENP), one of the largest wetland ecosystems in the world. It is bordered by coastal levees and mangrove swamps of the Everglades to the north and by the Florida Keys, a Pleistocene reef, to the south and east (McIvor et al., 1994). Its bathymetry is characterized by many small, shallow, interconnected basins separated by mud banks, with an average water depth of only 1-2 meters (Wanless and Tagett, 1989). It is about $2200 \mathrm{~km}^{2}$ in total area, with $1800 \mathrm{~km}^{2}$ included within ENP (Lidz and Rose, 1989). As a semi-closed bay, it receives freshwater from the Everglades and salty water from the Atlantic Ocean and Gulf of Mexico. Because of the existence of the mud banks, Florida Bay can be divided into four zones: (1) small, discontinuous, erosional mud banks in the inner Destructional Zone in eastern Florida Bay, generally considered as sediment starved; (2) an anastomosing maze of narrow, continuous banks in the Central Migration Zone of central Floridal Bay, receiving a sufficient sediment supply to maintain its banks; (3) broad, numerous mudbanks in the Western Constructional Zone in western Florida Bay, usually receiving an excess sediment supply; and (4) scattered, erosional bank remnants in the Outer Destructional Zone in southern Florida Bay (Enos, 1989; Wanless and Tagett, 1989). 
Circulation in the bay is partially restricted by these mud banks. The tides are semidiurnal and have an average range of $60 \mathrm{~cm}$ on the Atlantic side of the Florida Keys (Wanless and Tagett, 1989). However, they are dampened to less than $15 \mathrm{~cm}$ amplitude inside the bay, since tidal energy can be quickly attenuated by the mud banks, such that there is barely any lunar tide over most of central and northeastern Florida Bay (Wanless and Tagett, 1989). Strong, prolonged winds may cause greater changes in water level than lunar tides. Tropical storms or hurricanes, for instance, may override tides throughout the whole bay (Wanless and Tagett, 1989). Water depth varies seasonally, usually with the greatest depth from August to November and the shallowest from February to May (Fourqurean and Robblee, 1999). Annual evaporation is more than precipitation, with about three-quarters received during the wet season (Price et al., 2008). The mean annual temperature is about $24.5^{\circ} \mathrm{C}$, with a relative low mean monthly temperature in January and high values in August (Fourqurean and Robblee, 1999).

\section{General Approaches of Study}

\section{Coring sites}

Eight cores were taken from Bob Allen Bank (BA), Ninemile Bank (NB), Trout Cove (TC) and Russell Key (RK) in Florida Bay by Collins and others in June and August, 2002. Two adjacent cores (around $100 \mathrm{~m}$ apart) plus side- by-side replicates were taken from each site. They were selected from a transect which crosses the whole bay from Trout Cove in the northeast to Ninemile Bank in the southwest. These sites were selected for the following reasons: 
1. Ninemile Bank was thought to have a sedimentary record over 5000 years old (Enos, 1989). Because it is contiguous with the Gulf of Mexico, a relatively stable salinity history and a continuous seagrass record were expected at this site.

2. Bob Allen Key is near the center of Florida Bay. Previous studies from this area (Halley and Rouler, 1999; Brewster-Wingard and Ishman, 1999) documented a relatively continuous sedimentary record and salinity changes during the last two decades.

3. Russell Key is much closer to the Everglades mainland than the above two sites and hence, may have been more affected by human activities. Schmidt (1979) pointed out that there had been a large change in seagrass communities since the 1960's.

4. Trout Cove is located in a small, enclosed lagoon of the eastern bay and also very close the mainland, and thus, was expected to have recorded the largest salinity changes. The average length of each core was $2 \mathrm{~m}$. Of these four sites, two of them (Bob Allen Key and Ninemile Bank) contained peat at the base. The cores were sliced every $2 \mathrm{~cm}$ into samples that were then divided among researchers for analysis of age, diatoms, foraminifera, stable isotopes and biomarkers. Foraminiferal samples were around 1/8 of each 2-cm slice.

\section{Ages of Samples}

The radioactive isotope ${ }^{210} \mathrm{~Pb}$ was measured by Charles Holmes, U.S. Geological Survey, to date shells from the core sediments less than 120 years old. ${ }^{14} \mathrm{C}$ dating by Beta Analytic Inc., Miami, was used to date the core sediments back to about 4000 years ago. Twenty-one ${ }^{14} \mathrm{C}$ ages for the four cores were obtained by Collins. 


\section{Preparation and Identification of Foraminifera}

Two hundred and three samples were soaked in freshwater to facilitate disaggregation and were sieved to obtain sediments of grain size $>63 \mu \mathrm{m}$. The sample residues were split using a microsplitter until 300-400 specimens could be picked from each sample. The foraminifera were picked, sorted onto cardboard slides and identified to species under the light microscope.

\section{Statistical Analysis}

Four statistical methods were used to analyze the results: cluster analysis, discriminant analysis, analysis of variance (ANOVA) and Fisher's $\alpha$. Counts of species in any sample were transformed from percentage data using the relationship $2 \arcsin p^{1 / 2}$, where $p=$ percentage datum (Collins, 1993). Cluster analysis (unconstrained by stratigraphic position), a multivariate procedure for detecting natural groupings in data, was performed using Ward's method, one of the best available hierarchical clustering algorithms (Milligan, 1980), to calculate the distance between two clusters as the sum of squares between the two clusters added up over all the species (Wilkinson et al., 2004). Analysis of variance (ANOVA), a statistical method for determining whether significant differences exist between two or more groups, was used to examine variations in the composition of the foraminiferal assemblages among defined intervals. Discriminant analysis, a technique that examines the set of variables or predictors associated with a given subject and uses similarities and differences to assign the subject to a group or class, was used to see how well the intervals of time could be distinguished on the basis of the foraminiferal assemblages, and which species contributed most to the discrimination. 
Fisher's $\alpha$, a mathematical model defined by the formula: $S=\alpha x \ln (1+n / \alpha)$ where $S$ is the number if species, $\mathrm{n}$ is the number of individuals, and $\alpha$ is the diversity index (Hayek and Buzas, 1997), was used to measure diversity of the assemblages. 


\section{REFERENCES}

Barbosa, C. F., Scott, D. B., Seoane, J. C. S., and Turcq, B. J., 2005, Foraminiferal zonations as base lines for quaternary sea-level fluctuations in south-southeast Brazilian mangroves and marshes: Journal of Foraminiferal Research, v. 35, p. 22-43.

Bock, W. D., 1967, Monthly variation in the foraminiferal biofacies on Thalassia and sediment in the Big Pine Key area, Florida.

Bock, W. D., Lynts, G. W., Smith, S., Wright, R., Hay, W. W., and Jones, J. I., 1971, A symposium of recent south Florida Foraminifera: Miami Gelogical Society, Memoir I.

Boyer, J. N., and Fourqurean, J. W., 1997, Spatial characterization of water quality in Florida Bay and Whitewater Bay by multivariate analyses: zones of similar influence: Estuaries, v. 20, p. 743-758.

Boyer, J. N., Fourqurean, J. W., and Jones, R. D., 1999, Seasonal and long-term trends in the water quality of Florida Bay (1989-1997): Estuaries, v. 22, p. 417-430.

Brewster-Wingard, G. L., and Ishman, S. E., 1999, Historical trends in salinity and substrate in central Florida Bay: a paleoecological reconstruction using modern analogue data: Estuaries, v. 22, p. 369-383.

Butler, M. J., Hunt, J. H., Herrnkind, W. F., Childress, M. J., Bertelsen, R., Sharp, W., Matthews, T., Field, J. M., and Marshall, H. G., 1995, Cascading disturbances in Florida Bay, USA: Cyanobacterial blooms, sponge mortality, and implications for juvenile spiny lobsters panulirus argus: Marine Ecology Porgress Series, v. 129, p. 119-125.

Cann J. H., Harvey, N., Barnet, E. J., Belperio, A. P., and Bourman, R. P., 2002, Foraminiferal biofacies eco-succession and Holocene sealevels, Port Piries, South Australia: Marine Micropaleontology, v. 44, p. 31-55.

Carlson, P. R., Yarbro, L. A., and Barber, T. A., 1994, Relationship of sediment sulfide to mortality of Thalassia testudinum in Florida Bay: Bulletin of Marine Science, v. 54, p. 733-746.

Collins, Laurel S., 1993, Neogene paleoenvironments of the Bocas Del Toro Basin, Panama: Journal of Paleontology, v. 67, p. 699-710.

Cronin, T. M., Holmes, C. W., Wingard, G., Ishman, S., Dowsett, H., and Waibel, N., 2001, Historical trends in epiphytal ostracodes from Florida Bay: Implications for seagrass and macro-benthic algal variability: Bulletins of American Paleontology, v. 361, p. $159-197$. 
Culver, S. J., 1990, Benthic foraminifera of Puerto Rican mangrove-lagoon systems: potential for paleoenvironmental interpretations: Palaios, v. 5, p. 34-51.

Davies, T. D., and Cohen, A. D., 1989, Composition and significance of the peat deposits of Florida Bay: Bulletin of Marine Science, v. 44, p. 387-398.

Durako, M. J., Hall, M. O., and Merello, M., 2002, Patterns of change in the seagrass dominated Florida Bay hydroscape: The Everglades, Florida Bay, and Coral Reefs of the Florida Keys: An Ecosystem Sourcebook, (eds. Porter, J. W., and Porter, K. G.), CRC Press, Boca Raton, Florida, pp. 523-537.

Enfield, D. B., Mestas-Nunez, A. M., and Trimble, P. J., 2001, The Atlantic multidecadal oscillation and its relation to rainfall and river flows in the continental U. S.: Geophysical Research Letters, v. 28, p. 2077-2080.

Enos, P., 1989, Islands in the bay — a key habitat of Florida Bay: Bulletin of Marine Science, v. 44, p. 365-386.

Enos, P., and Perkins, R. D., 1979, Evolution of Florida Bay from island stratigraphy: The Geological Society of American Bulletin, v. 90, p. 59-83.

Fairbridge, R. W., 1974, The Holocene sea-level record in south Florida, in Environments of south Florida: present and past, in Gleason P. J., ed., Miami Geological Society, Memoir 2. pp. 223-232.

Fairbridge, R. W., 1976, Shellfish-eating preceramic Indians in coastal Brazil: Science, v. 191, p. 353-399.

Froede, C. R., 2002, Rhizolith evidence in support of a late Holocene sea-level highstand at least 0.5m higher than present at Key Biscayne, Florida: Geology, v. 30, p. 203-206.

Fourqurean, J.W., Jones, R.D., and Zieman, J.C., 1993, Processes influencing water column nutrient characteristics and phosphorus limitation of phytoplankton biomass in Florida Bay, FL, USA: Inference from spatial distributions: Estuarine Coastal and Shelf Science, v. 35, p. 295-314.

Fourqurean, J. W., and Robblee, M. B., 1999, Florida Bay: a history of recent ecological changes: Estuaries, v. 22, p. 345-357.

Gehrels, W. R., Kirby, J. R., Prokop, A., Newnham, R. M., Achterberg, E. P., Evans, H., Black, S., and Scott, D. B., 2005, Onset of recent rapid sea-level rise in the western Atlantic Ocean: Quaternary Science Reviews, v. 24, p. 2083-2100. 
Gleason, P. J., and Stone, P., 1994, Age, origin, and landscape evolution of the Everglades peatland, in Davis, S. M., and Ogden, J. C., eds., Everglades: its ecosystem and its restoration: Delary Beach, Florida, St. Lucie Press, p. 149-197.

Halfar, J., and Ingle, J. C., 2003, Modern warm-temperate and subtropical shallow-water benthic foraminifera of the southern gulf of California, Mexico: Journal of Foraminiferal Research, v. 33, p. 309-329.

Hall, M. O., Durako, M. J., Fourqurean, J. W., and Zieman, J. C., 1999, Decadal changes in seagrass distribution and abundance in Florida Bay: Estuaries, v. 22, p. 445-459.

Halley, R. B., and Rouler, L. M., 1999, Reconstructing the history of eastern and central Florida Bay using mollusk-shell isotope records: Estuaries, v. 22, p. 358-368.

Hayer, Lee-Ann C., and Buzas, M. A., 1997, Serveying Nautral Populations: New York, Columbia University Press, 563 p.

Hill, T., Brooks, G.R., Duncan, D. S., and Medioli, F. S., 2003, Benthic foraminifera of the Holocene transgressive west-central Florida inner shelf: paleoenvironmental implications: Marine Geology, v. 200, p. 263-272.

Horton, B. P., Larcombe, P., Woodroffe, S. A., Whittaker, J. E., Wright, M. R., and Wynn, C., 2003, Contemporary foraminiferal distribution of a mangrove environment, Great Barrier Reef coastline, Australia: implications for se-level reconstructions: Marine Geology, v. 198, p. 225-243.

Horton, B. P., Whittaker, J. E., Thomson, K. H., Hardbattle, M. I. J., Kemp, A., Woodroffe, S. A., and Wright, M. R., 2005, The development of a modern foraminiferal data set for sea-level reconstructions, Wakatobi Marine National Park, Southeast Sulawest, Indonesia: Journal of Foraminiferal Research, v. 35, p. 1-14.

Huvane, J. K., and Cooper, S. R., 2001, Diatoms as indicators of environmental change in sediment cores from northeastern Florida Bay: Bulletin of American Paleontology, number 361, p. 145-158.'

Ishman, E. S., Graham, I., and Ambrosio, J., 1997, Modern benthic foraminifer distributions in Biscayne Bay: Analogs for historical reconstructions: open file report 9734, U.S. Geological Survey.

Kelble, C. R., Johns, E. M., Nuttle, W. K., Lee, T. N., Smith, R. H., and Ortner, P. B., 2007, Salinity patterns of Florida Bay: Estuarine, Coastal and Shelf Science, v. 71, p. 318-334.

Langer, M. R., 1993, Epiphytic foraminifera: Marine Micropaleontology, v. 20, p. 235265. 
Lidz, B. H., and Rose, P. R., 1989, Diagnostic foraminiferal assemblages of Florida Bay and adjacent shallow waters: a comparison: Bulletin of Marine Sciences, v. 44, p. 399418.

Light, S. S., and Dineen, J. W., 1994, Water control in the Everglades: a historical perspective, in Everglades: the ecosystem and its restoration, (eds S. M. Davis and J. C. Ogden), St. Lucie Press, pp. 47-84.

Lirman, D., and Cropper, W. P., 2003, The influence of salinity on seagrass growth, survivorship and distribution within Biscayne Bay, Florida: field, experimental, and modeling studies: Estuaries, v. 26, p. 131-141.

McIvor, C. C., Ley, J. A., and Bjork, R. D., 1994, Changes in freshwater inflow from the Everglades to Florida Bay, in Everglades: the ecosystem and its restoration, (eds S. M. Davis and J. C. Ogden), St. Lucie Press, pp. 117-146.

McMillan, C. and Moseley, F. N., 1967, Salinity tolerance of five marine spermatophytes of redfish Bay, Texas: Ecology, v. 48, p. 503-506.

Milligan, G. W., 1980, An examination of the effect of six types of error perturbation on fifteen clustering algorithms: Psychometrika, v. 45, p. 325-342.

Missimer, T. M., 1980, Holocene sea level changes in the Gulf of Mexico: An unresolved controversy, in Upchurch, S. B., ed., Holocene geology and man in Pinellas and Hillsborough Counties, Florida: Tallahassee, Florida, Southeastern Geological Society, Southeastern Geological Society Guidebook, v. 22, p. 19-23.

Montague, C. L., and Ley, J. A., 1993, A possible effect of salinity fluctuation on abundance of benthic vegetation and associated fauna in northeastern Florida Bay: Estuaries, v. 16, p. 703-717.

Murray, J. W., 1991, Ecology and Palaeoecology of Benthic Foraminifera: Palaeontological Association, 397 pp.

Murray, J. W., 2000, When does environmental variability become environmental change? The proxy record of benthic foraminifera, in Environmental Micropaleontology: the application of microfossils to environmental geology, (ed R. E. Martin), Kluwer Academic Publishers, pp. 9-11.

Phleger, F. B., 1966, Patterns of living marsh foraminifera in south Texas coastal lagoons: Boletin de la Sociedad Geologica Mexiana, v. 28, p. 1-44.

Philips, E. J., and Badylak, S., 1996, Spatial variability in phytoplankton standing stock and composition in a shallow inner-shelf lagoon, Florida Bay, Florida: Bulletin of Marine Science, v. 58, p. 203-216. 
Price, R. M., Nuttle, W. K., Cosby, B. J., and Swart, P. K., 2008, Variation and Uncertainty in evaporation from a subtropical esturary: Florida Bay: Estuaries and Coasts, v. 30, p. 497-506.

Rose, R. P., and Lidz, B. H., 1977, Diagnostic foraminiferal assemblages of shallowwater modern environments: south Florida and the Bahams: Sedimenta VI.

Rudnick, D.T., Childers, D. L., and Fontaine, T. D., 1999, Phosphorous and nitrogen input to Florida Bay: the importance of the Everglades watershed: Estuaries, v. 22, p. 398-416.

Saunders, J. B., 1958, Recent foraminifera of mangrove swampls and river esturaries and their fossil counterparts in Trinidad: Micropaleontology, v. 4, p. 79-92.

Schmidt, T. W., 1979, Ecological study of fishes and water quality characteristics of Florida bay, ENP, FL. US NPS RSP-EVER N-36.

Scholl, D. W., Craighead, F. C., and Suiver, M., 1969, Florida submergence curve revisited: its relation to coastal sedimentation rates: Science, v. 163, p. 562-564.

Scott, D. B., Medioli, F. S., and Schafer, C. T., 2001, Monitoring in coastal environments using foraminifera and thecamoebian indicators: Cambridge University Press, p. 28-93.

Sen Gupta, B. K., 1999, Foraminifera in marginal marine environments, in Modern Foraminifera, (ed B. K. Sen Gupta), Kluwer Academic Publishers, The Netherlands, pp. 157-159.

Shepard, F. P., 1963, Thrity-five thousand years of sea level, in Clements, T., ed., Essays in marine geology: Los Angeles, University of California Press, p. 1-10.

Steinker, D. C., 1977, Foraminiferal studies in tropical carbonate environments: south Florida and Bahamas: Earth and Planetary Sciences, v. 40, p. 46-61.

Swart, P. K., Healy, G., Greer, L., Saied A., Anderegg, D., Dodge, R. E., 1999, The use of proxy chemical records in coral skeletons to ascertain past environmental conditions in Florida Bay: Estuaries, v. 22, p. 384-397.

Tomasko, D. A., Dawes, C. J., and Hall M. O., 1996, The effect of anthropogenic nutrent enrichment on Turtle Grass (Thalassia testudinum) in Sarasota Bay, Floirda: Estuaries, v. 19 , p. 448-456.

Vance, D. J., Culver, S. J., Corbett, D. R., and Buzas, M. A., 2006, Foraminifera in the albemarile estuarine system, north Carolina: distribution and recent environmental change: Journal of Foraminiferal Research, v. 36, p. 15-33. 
Walker, K. J., Stapor, F. W., and Marquardt, W. H., 1995, Archaeological evidence for a 1750-1450 BP higher-than-present sea level along Florida's Gulf Coast, in Finkl, C. W., ed., Holocene cycles: Climate, sea levels, and sedimentation: Journal of Coastal Research, Special Issue 17, p. 205-218.

Wanless, H. R., and Tagett, M. G., 1989, Origin, growth and evolution of carbonate mudbanks in Florida Bay: Bulletin of Marine Science, v. 44, p. 454-489.

Wilkinson, L., Engelman, L., Corter, J., and Coward, M., 2004, Cluster analysis: SYSTAT 11, Statistics I, p.57-91.

Winkler, M. G., Sanford, P. R., and Kaplan, S., 1999, Americas lake-level database. Program and Abstract of the $14^{\text {th }}$ Biennial Meeting of the American Quaternary Association. Flagstaff, Arizona, $191 \mathrm{pp}$.

Woodroffe, S. A., Horton, B. P., Larcombe, P. L., and Whittaker, J. E., 2005, Intertidal mangrove foraminifera from the central great barrier reef shelf, Australia: implications for sea-level reconstruction: Journal of Foraminiferal Research, v. 35, p. 259-270.

Zieman, J. C., Fourqurean, W. J., and Iverson, R. L., 1989, Distribution, abundance and productivity of seagrasses and macroalgae in Florida Bay: Bulletin of Marine Science, $\mathrm{v}$. 44, p. 292-311.

Zieman, J. C., Fourqurean, J. W., and Frankovich, T. A., 1999, Seagrass die-off in Florida Bay: long-term trends in abundance and growth of turtle grass, Thalassia testudinum: Estuaries, v. 22, p. 460-470. 


\section{CHAPTER 2}

\section{HISTORICAL SEAGRASS ABUNDANCE OF FLORIDA BAY}

\section{Introduction}

A large seagrass die-off in Florida Bay from 1987 to 1994 drew the attention of the public to the link between seagrass abundance and water quality (Zieman et al., 1989; Fourqurean et al., 1993; Montague and Ley, 1993; Tomasko et al., 1996; Fourqurean and Robblee, 1999; Boyer et al., 1999). Seagrasses are subject to continual stresses and disturbances that are related to changes in environment. They are fairly sensitive to salinity variation, eutrophication and light availability (Lirman and Cropper, 2003). These characteristics make them good indicators of water quality (Durako et al., 2002). Rehabilitation of the ecosystem to an anthropogenically unaltered state has been considered since the seagrass dieoff, but this should be guided by a comprehensive understanding of the natural- versus human-induced variability that has existed over the past $\sim 100$ years (Fourqurean and Robblee, 1999).

Studies (Braiser, 1975; Martin and Wright, 1988; Richardson, 2000; Steinker and Steinker, 1976) suggest some benthic foraminieral species prefer to living on seagrass blades than in the sediments. These species are termed 'seagrass-associated benthic foraminifera' in this research. Preliminary research (Collins et al., 2004) has suggested that seagrass-associated benthic foraminifera are good indicators of seagrass abundance, so they should be useful in reconstructing seagrass abundance from the fossil record, which rarely preserves seagrass itself. The major purpose of this research is to study the historical abundance of seagrasses using benthic foraminifera as a proxy to understand 
natural and anthropogenic environmental changes of the past that are related to water quality.

As in other coastal ecosystems throughout the world, seagrass beds are vitally important components in Florida Bay. Few areas contain meadows as well developed as those found in Florida Bay, which contains one of the world's most extensive seagrass beds (ca. $1800 \mathrm{~km}^{2}$; Zieman et al., 1999). Seagrass beds are important to the health of coastal ecosystems because they contribute to productivity and the carbon budget, and help stabilize seafloor sediments (Lirman and Cropper, 2003). They also provide critical habitat for commercially and economically useful fisheries species (Durako et al., 2002).

Three species of seagrasses, Syringodium filiforme (manatee grass), Halodule wrightii (shoal grass) and Thalassia testudinum (turtle grass), covered over $80 \%$ of the bottom of Florida Bay prior to the seagrass die-off that began in 1987 (Zieman et al., 1989). Among them, T. testudinum is by far the most widespread and abundant species in Florida Bay and its distribution has changed little over the last decade (Hall et al., 1999). Several studies (McMillan and Moseley, 1967; Montague and Ley, 1993; Lirman and Cropper, 2003) focusing on seagrasses concluded the following: $H$. wrightii is broadly euryhaline; S. filiforme is the most susceptible seagrass species and maximum growth rates occurred at 25 psu salinity and dropped dramatically at higher or lower values; and T. testudinum prefers to live in the nearshore with the salinity range between $30 \mathrm{psu}$ and $40 \mathrm{psu}$. According to McMillan and Moseley (1967), S. filiforme and T. testudinum stopped growing when salinity was around 45-60 psu. Unlike the other two types, $H$. wrightii has a high tolerance to salinity variation (Montague and Ley, 1993) and the ability to survive near the canal where salinity may be greatly affected by freshwater inputs (Montague and 
Ley, 1993). Furthermore, it can continue to grow with extremely high values of salinity, up to $72 \mathrm{psu}$ (McMillan and Moseley, 1967). The broad blades of Thalassia make them a better habitat for benthic foraminifera than other types of seagrass and local algae (Fujita and Hallock, 1999), and 66 foraminiferal species have been found living on the Thalassia blades (Bock, 1969).

In the 1987-1994 seagrass dieoff, two phases of seagrass loss were found (Durako et al., 2002). The first phase was characterized by the initial die-off of seagrasses from 1987 to early 1991 (Fourqurean and Robblee, 1999). During this period, only T. testudinum experienced significant decline. In 1991, over ca. $40 \mathrm{~km}^{2}$ of seagrasses were completely lost and another $240 \mathrm{~km}^{2}$ were affected (Fourqurean and Robblee, 1999). Following the initial seagrass die-off, the water column gradually became turbid and microalgae began to thrive, leading to a sponge die-off (Butler et al., 1995) and further decline of seagrass beds which had survived through the initial seagrass die-off (Hall et al., 1999). Unlike the first phase, this second phase (1991-1994) affected all seagrass species. The total seagrass die-off led to pronounced ecological changes such as sediment resuspension and the decline of water clarity, a sponge die-off, phytoplankton blooms and a decline in fishery harvests (Fourqurean et al., 2002).

Although many papers have been published since 1989 regarding this seagrass die-off, no exact causes or ultimate mechanisms can completely explain it (Fourqurean and Robblee, 1999). Anthropogenic nutrient enrichment is considered to be the most plausible cause of seagrass die-off throughout the world (Tomasko et al., 1996). Other important environmental factors such as salinity, water clarity and algal abundance also play important roles in controlling seagrass distribution. However, unlike other documented 
seagrass loss in the world, the 1987 initial seagrass die-off was believed to be unrelated to water turbidity or algal blooms since no pronounced decreases in water clarity or increases in algal abundance had been observed before this event (Fourqurean and Robblee, 1999). Carlson et al. (1994) suggested that the early die-off could be the result of hypoxia and sulfide toxicity of the water. Lirman and Cropper (2003) believed that the hypersalinity caused by a multiyear drought during the late 1980s and long-term water management contributed to the stress on T. testudinum. Other hypotheses include overdevelopment of seagrass beds, infilling of the bay due to less severe storms (Fourqurean and Robblee, 1999), eutrophication (Lapointe and Clark, 1992), and pathogens (Durako and Kuss, 1994). The loss of seagrasses then resulted in sediment resuspension and algal blooms, leading to extensive and persistent water turbidity in the Bay and great light attenuation (Fourqurean and Robblee, 1999), which in turn threatened more seagrass habitats. Besides these factors, extremely high temperatures and an imbalance in the ratio of photosynthesis to respiration may also have stressed the seagrasses (Zieman et al., 1999).

This study addresses three questions: (1) Are the presumed seagrass-associated foraminifera good indicators for trends in seagrass abundance? (2) How has seagrass abundance changed on a decadal scale in the last 120 years? (3) How has seagrass abundance fluctuated through time on a centennial to millennial scale over the last 4000 years? In order to answer the above questions, the results will be separated into three parts, respectively: (1) The abundance of the presumed seagrass-associated foraminifera covering 1970-2001 are compared with the documented seagrass dieoff period between 1987 and 1994 to test its use as a proxy for seagrass abundance. (2) More recent 
historical trends of seagrass abundance from $1880-2001$, dated with the ${ }^{210} \mathrm{~Pb}$ method, are compared to the timing of known human-induced events to examine whether anthropogenic vs. natural variability had more effect. (3) Long-term variability in seagrass abundance, with samples dated using ${ }^{14} \mathrm{C}$, are examined over the past $\sim 4,000$ years.

\section{Methods}

\section{Core sites and Sampling}

Eight cores were collected by the U.S. Geological Survey with a piston-coring device at Bob Allen Bank, Ninemile Bank, Trout Cove and Russell Key in Florida Bay (Figure 2.1, Table 2.1). Two cores (around $100 \mathrm{~m}$ apart) were taken from each site. These sites were selected because they receive different sources of freshwater runoff and seawater. Trout Cove is close to the mainland and is more likely to be affected by the freshwater runoff; Ninemile Bank is furthest from the mainland and the Florida Keys, so it is projected to be minimally affected by human activity, and it is mostly influenced by the Gulf of Mexico; and Bob Allen Bank and Russell Key are located in the central bay and are hypothesized to be more affected by processes on both the mainland and the Keys. All cores were taken through calcareous muds to the limestone substratum and had an average length of $1.5 \mathrm{~m}$. Of these four sites, two (Bob Allen and Ninemile Bank) contained peat at the base. In order to determine the presence of bedding and to evaluate the extent of mixing, each core was x-rayed before sampling. Examination showed that all cores were well bioturbated with little visible bedding. Of these eight cores, only six (two cores each from Bob Allen Bank and Russell Key, and one each from Ninemile Bank and Trout Cove) 
were analyzed in the study because of time constraints. The details of the selection of the four sites are as follows:

1) Ninemile Bank has a sedimentary record of over 4,000 years (Enos, $1989 ;{ }^{14} \mathrm{C}$ ages of this project). Because it is contiguous with the Gulf of Mexico, it should have had a relatively stable salinity history, less likely to be affected by evaporation and runoff from the mainland, and continuous record of seagrass abundance because it is furthest from the mainland and thus, anthropogenic activity. Therefore, only one core from Ninemile Bank was analyzed as an end member in the bay transect.

2) Bob Allen Bank is near the center of Florida Bay, which could be expected to have more intra- and inter-annual variation in environmental conditions and related seagrass abundance fluctuation. Previous studies (Halley and Rouler, 1999; Brewster-Wingard and Ishman, 1999) documented a fairly continuous sedimentary record and salinity changes during the last two decades. Two cores from this area were taken and analyzed for benthic foraminifera.

3) Russell Key, also in central Florida Bay, is a few hundred meters across and about $1 \mathrm{~km}$ long (Cronin et al., 2001). Russell Key accreted in a southward direction (Wanless and Tagett, 1989), and lies much closer to the Everglades mainland than the above two sites. Two cores were taken and analyzed from this area.

Both Bob Allen Bank and Russell Key are strategically situated in the central part of Florida Bay, where the greatest loss of seagrass and water turbulence was experienced during the late 1980s to early 1990s (Fourqurean and Robblee, 1999). Schmidt (1979) pointed out that there had been a large change in seagrass communities in the central bay 
since the 1960s. Therefore, historical records from these cores are good candidates for detecting water quality changes related to seagrass abundance in the past.

4) The sampling site near Trout Cove is located very close to the mainland in the northeastern bay, and therefore is more likely to have been affected by freshwater runoff from the Everglades. The seagrass abundance has been consistently low in this area (personal communication, 2008, James Fourqurean) because of low salinity. Therefore, only one core was analyzed as the other end member of a SW to NE bay transect.

The cores were sliced completely into 2-cm-thick samples, which were divided among researchers for anlysis. Each sample was divided into several parts for different research groups: $1 / 2$ was used to determine ages, $1 / 4$ was reserved for nutrient and stable isotope studies, $1 / 8$ was used for diatom research, and 1/8 was for foraminiferal research (this study).

\section{Age Determinations.}

The method of ${ }^{210} \mathrm{~Pb}$ dating has been used primarily on lake sediments within the time range of 1-120 years. This method is based on the escape of radon gas from the earth into the atmosphere, and the radioactive disequilibrium between ${ }^{210} \mathrm{~Pb}$ and its parent, ${ }^{226} \mathrm{Ra}$ (Holmes et al., 2001). An assumption of this method is that the radium distribution is constant and equal to the value where the total ${ }^{210} \mathrm{~Pb}$ activity is constant with depth (Holmes et al., 2001).

The ${ }^{210} \mathrm{~Pb}$ method of age determination was described by Holmes et al. (2001), who ran the analyses at the U.S. Geological Survey, St. Petersburg, Florida, for this project and contributed ages based on a model for each core. Of the two models that have usually 
been used to calculate the age, the constant rate of supply model and the constant initial concentration model, the first model is used in this study. The constant rate of supply model assumes that the flux of ${ }^{210} \mathrm{~Pb}$ is constant over time regardless of how the sediment flux might vary, while the constant initial concentration model assumes that the concentration of ${ }^{210} \mathrm{~Pb}$ at time zero (when the sediment was deposited) has been constant over time.

The limitations of ${ }^{210} \mathrm{~Pb}$ dating preclude precise inter-site comparisons of interannual trends, especially during the late $19^{\text {th }}$ to early $20^{\text {th }}$ centuries when the precision of ${ }^{210} \mathrm{~Pb}$ dating is diminished to about \pm 5 years (Holmes, written communication, 2006). Therefore, in this research, only periods between 1880 and 2001 (a span of $\sim 120$ yearsthe outside limit of the method applied to these cores) are considered.

Materials measured by the radiometric technique were analyzed by synthesizing sample carbon to benzene $(92 \% \mathrm{C})$, measuring for ${ }^{14} \mathrm{C}$ content in one of 53 scintillation spectrometers, and then calculating for radiocarbon age. Marine carbonate samples were corrected for ${ }^{13} \mathrm{C} /{ }^{12} \mathrm{C}$, and both global and local geographic reservoir effects (Stuiver, et al., 1998). The calibations were calculated using the latest (1998) calibration database (Stuiver, et al., 1998; Talma and Vogel, 1993). Ages (Table 2.2) have the units "B.P." (Before Present), where "Present" is defined as A.D. 1950 for the purposes of radiocarbon dating.

\section{Preparation and Identification of Benthic Foraminifera}

Two hundred and three sediment samples were soaked in freshwater to disaggregate sediments, then sieved to obtain grain sizes $>63 \mu \mathrm{m}$, which includes all adult and nearly 
all juvenile foraminifera. The sample residues were split until 300-400 specimens (a statistically significant sample) could be picked from a sample split (Murray, 1991). The foraminifera were picked, sorted onto cardboard slides and identified to species under the light microscope.

Foraminifera were identified to the species level and classified as seagrass-associated or non-seagrass-associated. Seagrass-associated foraminifera are defined as foraminifera which have been found to be more abundant on seagrass than in the surrounding sediments.

There is considerable taxonomic and ecologic data on benthic foraminiferal populations collected from bays and estuaries along the Atlantic and Gulf of Mexico coasts. Species were identified following the taxonomy of Bock (1969), Bock et al. (1971), Rose and Lidz (1977), Wantland (1967), and Buzas and Severin (1982). The online identifications in many cases were checked against type specimens at the U.S. National Museum of Natural History. The Catalogue of Foraminifera (Ellis and Messina, 1941-2009) was used for the original descriptions of species. The full names of taxa are listed in Appenidx 1.

\section{Data Analysis}

Three statistical methods were used to analyze the results, as follows. Counts of species in any sample were transformed from percentage data using the relationship 2 $\arcsin p^{1 / 2}$, where $p=$ percentage datum (Collins, 1993). The stratigraphically constrained cluster analysis CONISS (Grimm, 1987), a multivariate method for quantitative definition of stratigraphic zones, was performed to determine the associations between the foraminiferal distributions. As opposed to the standard, unconstrained cluster analysis, 
only stratigraphically adjacent clusters are considered for merging. The method of incremental sum of squares has been used widely for unconstrained cluster analyses. Analyses of variance (ANOVA) were used to test the variations in percentages of seagrass-associated foraminifera among independent intervals defined by human-induced events (Tables 2.3 and 2.4) to identify statistically significant trends through time.

Discriminant analysis was used to see how well the intervals of time could be distinguished on the basis of the foraminiferal assemblages, and which species contributed most to the discrimination. This type of analysis is related to both multivariate analysis of variance and multiple regression. The sample values are grouped in cells as in a one-way multivariate analysis of variance, and the variables form an equation similar to that for multiple regression. In discriminant analysis, Wilks' lamba, the same test used in the multivariate ANOVAs, is used to test multivariate differences among groups (Engelman, 2004).

\section{Results}

\section{Age Determinations}

Sediment accumulation rates from six cores were calculated based on the ${ }^{210} \mathrm{~Pb}$ data provided (Table 2.5). The results show that sediment accumulation rates varied considerably between cores, even those from the same site. ${ }^{210} \mathrm{~Pb}$-derived ages between about 1970 and 2001 have a range of less than \pm 2 years, and older samples can generally vary up to \pm 5 years (C. Holmes, written communications, 2004, 2008). Therefore, restricted by the limitations of the ${ }^{210} \mathrm{~Pb}$ dating method, the maximum depth with measurable excess ${ }^{210} \mathrm{~Pb}$ activity was determined for each core (Table 2.5). However, this 
study goes slightly further back, to 1880 , since the model can be extended a bit beyond the exact limits of the excess ${ }^{210} \mathrm{~Pb}$ to compare a similar period of time among the six cores (C. Holmes, written communication, 2008). Two cores from Bob Allen Bank have linear sediment accumulation rates of 0.36 and $0.68 \mathrm{~cm} \mathrm{yr}^{-1}$. The period of the last 120 years was represented by the $86-\mathrm{cm}$ core and $40-\mathrm{cm}$ core from this area. At Russell Bank, rates were remarkably higher, 1.18 and $1.82 \mathrm{~cm} \mathrm{yr}^{-1}$, and the $140-\mathrm{cm}$ core and $148-\mathrm{cm}$ core representing the last 120 and 80 years, respectively. The 92-cm core from Ninemile Bank covers a period of approximately 120 years with an average accumulation rate of about $0.82 \mathrm{~cm} \mathrm{yr}^{-1}$. The Trout Cove core, closest to the mainland, has the lowest sediment accumulation rate of $0.38 \mathrm{~cm} \mathrm{yr}^{-1}$ and the last 120 years were represented by only a 46cm core.

\section{Seagrass-Associated Foraminifera}

The general ecologies of foraminiferal species were compiled from the literature on Florida Bay, Gulf of Mexico, Belize and the West Indies. Benthic foraminifera that have been found to have a closer association with seagrass than with the surrounding sediments are listed in Table 2.6. Variations in the percent abundance of these seagrassassociated foraminifera through time were then used to reconstruct the historic fluctuations of seagrass abundance. 


\section{Recent Seagrass Dieoff Period, $1970 \sim 2001$}

For this time period, all samples were prepared from the six cores. The error in ${ }^{210} \mathrm{~Pb}$ ages for this period is \pm 2 years, and is considered in the following results. Only the most abundant taxa are discussed below.

(1) Bob Allen Bank Core \#0206122. Among seagrass-associated foraminiferal species, Biloculina eburnea, Quinqueloculina subpoeyana, Triloculina rotunda and Paeteoris dilatata, but especially the first three, show higher percent abundances than the others during this period (Figure 2.2). Biloculina eburnea shows the largest changes in abundance (Figure 2.2). This species was more common and steadily abundant during the 1970s with great fluctuations in the 1980s -1990s. A great loss in percent abundance of $B$. eburnea is observed during the late $1980 \mathrm{~s}$ and early $1990 \mathrm{~s}$, when $P$. dilatata and $T$. rotunda also show decreases to nearly $0 \%$ (Figure 2.2 ). All three species show relatively high percent abundances during the 1970s. Quinqueloculina subpoeyana appears to have been an important component between 1970 and 2001 except for 1998, with maximum abundance between 1984 and 1993. The percent abundances of $Q$. polygona are stable in the 1980s and does not show decreases until the early 1990s. Although the times when this species show decreases in percent abundance do not match exactly, nearly all the species show relatively high abundances during the 1970s and early 1980s, and a gradual increase after $\sim 1990$ towards 2001 .

The cluster analysis (Figure 2.2) shows that the largest change in foraminiferal assemblages occurred between $12 \mathrm{~cm}$ (1987) and $10 \mathrm{~cm}$ (1990). Two clusters are identified: 22-12 cm (1972-1987) and 10-2 cm (1990-2001). 
Comparing the timing of the seagrass dieoff with three of the four most abundant seagrass-associated species, $T$. rotunda, B. eburnea and P. dilatata, they show a decline in percent abundance from 1987-1994, coinciding with the seagrass dieoff that began in 1987. The abundance of $Q$. subpoeyana also shows a decline from 1987 to 1998 and increases afterwards.

(2) Bob Allen Bank Core \#0206124. The age of the top $2 \mathrm{~cm}$ of the core is about 1987. Therefore, no information about how seagrass-associated foraminifera behaved during the documented seagrass dieoff period (1987-1994) can be obtained from this core. Similar to core $\# 0206122$ from the same site, the most abundant seagrass-associated foraminifera are B. eburnea, $P$. dilatata, Q. polygona, Q. subpoeyana and T. rotunda (Figure 2.3). Biloculina eburnea remained relatively stable in abundance throughout this period with the lowest value in 1987. Quinqueloculina subpoeyana had a maximum abundance in 1982 and decreased afterwards. Quinqueloculina polygona remained stable with a slight increase in 1987 , and $T$. rotunda and $P$. dilatata were fairly stable throughout this period.

The cluster analysis (Figure 2.3) shows samples that were successively joined one at a time, from oldest to youngest, so no large changes can be identified within that period. However, the results agree with those from the other Bob Allen Bank core. Core \#0206122 separates the samples between 1972 and 1987 as one group, and in Core $\# 0206124$, samples from this same time period are grouped together.

(3) Russell Key Core \#0206125. The most abundant seagrass-associated foraminiferal species are B. eburnea, P. dilatata, Q. polygona, Q. subpoeyana and T. rotunda (Figure 2.4), similar to the Bob Allen Bank cores. Biloculina eburnea, the most abundant species, 
was less abundant in 1984 and 1989. Although P. dilatata overall was sparse, it was lowest in 1989-1996 with a relatively great increase after that. Quinqueloculina polygona, Q. subpoeyana and T. rotunda have mostly corresponding pulses of increased abundance during the interval 1988-2001, with concurrent declines in 1991 and 1994. After 1998, $Q$. subpoeyana and T. rotunda reached their maximum abundance while Q. polygona remained low.

The cluster analysis (Figure 2.4) divides the samples into two main clusters: $38-6 \mathrm{~cm}$ (1971-1998) and 4-0 cm (2000-2001). Thus, the largest change occurs between 6 and 4 cm, corresponding to the late 1990s.

(4) Russell Key Core \#0206127. The most abundant seagrass-associated foraminiferal species are (as for the other Russell Key core) B. eburnea, Q. polygona, Q. subpoeyana, P. dilatata and T. rotunda (Figure 2.5). Biloculina eburnea and Q. subpoeyana have similar patterns of change in percent abundances. Both of them had relatively low abundances during the 1970s, increased to their maximum abundance during the early 1980 s, and declined in the late 1980s to early 1990s. Quinqueloculina polygona and T. rotunda behaved similarly during most of the 1968-2001 period. Their abundances peaked in the late 1970s, and declined during the 1980s -1990s, although $T$. rotunda shows a single peak in 1993. Except for a dip in 1977, P. dilatata had its lowest values from 1989-1996.

The cluster analysis (Figure 2.5) shows that the largest difference in seagrass-associated foraminiferal assemblages occurs between 38-34 cm (1981-1983). Three main clusters that are identified are: $60-38 \mathrm{~cm}(1968-1981), 34-26 \mathrm{~cm}$ (1983-1988) and 24-2 $\mathrm{cm}$ (19892001). 
For the two Russell Key cores, the principal clustering of assemblages is fairly different. However, pre-1983 assemblages are differentiated from 1984-1988 assemblages, which are differentiated from later ones. Assemblages that occurred during the recent seagrass dieoff (1987-1994) are not clustered as a group, although 1989-1991 assemblages are differentiated. A post-dieoff cluster, assuming \pm 2 years, can be seen in both cores: 2000 2001 in $\# 0206125$, and 1997-2001 in \#0206127.

(5) Ninemile Bank Core \#0208134. The percent abundances of seagrass-associated foraminifera show few changes throughout this time period (Figure 2.6). The most abundant taxa, similar to those of the other cores, are B. eburnea, $Q$. polygona, $Q$. subpoeyana, $P$. dilatata and $T$. rotunda. The changes are slight, except perhaps for the increase in Q. subpoeyana in 1993 onward. However, all species show an obvious increase in percent abundance between 1993 and 2001. The cluster analysis (Figure 2.6) separates the samples into three distinct groups: 28-24 cm (1966-1972), 18-6 cm (19801996) and 4-2 cm (1999-2001).

(6) Trout Cove Core \#02061211. The most abundant seagrass-associated foraminifera are $Q$. subpoeyana, $P$. proteus and $T$. rotunda, but only $T$. rotunda is present in sufficient numbers to interpret, and it remains stable throughout the period (Figure 2.7). The cluster analysis (Figure 2.7) shows the assemblages at $12 \mathrm{~cm}(1969)$ as different from the other, later ones, and the 10-8 cm (1974-1979) and 4-2 cm (1989-1994) assemblages are clustered separately.

(7) Trends in Seagrass-Associated Foraminifera. Total percentages of seagrassassociated benthic foraminifera were plotted against time for all cores (Figure 2.8). In Russell Key core \#0206127, the total percentage of seagrass-associated benthic 
foraminifera increased to its maximum value at $1983 \pm 2$ years, dropped to a low in 1992 \pm 2 years, and then fluctuated at relatively low values until 2001. In contrast, Russell Key core \#0206125 shows a fluctuating, gradual decrease until $1992 \pm 2$ years, then a fluctuating increase. The Bob Allen Bank cores show gradually decreasing trends with minor oscillations (although sediments after 1987 are missing for one). No large changes in total percentages of seagrass-associated benthic foraminifera are observed in the Ninemile Bank Core during this period, except for a small increase after 1996. In Trout Cove, values remained relatively constant until 1994, after which sediments are missing. The overall trends of the percent abundance of all seagrass-associated foraminifera show different patterns during the recent seagrass dieoff period (Figure 2.8), although all cores show a decrease between 1983 and $1986 \pm 2$ years, and the central bay cores (Bob Allen Bank, Russell Key) show relatively low values around 1991-1992 \pm 2 years. The changes do suggest the influence of the seagrass dieoff, especially in the central bay, on the seagrass-associated foraminiferal fauna, which indicates that these seagrassassociated foraminifera are good seagrass abundance indicators. The seagrass dieoff had less effect on the seagrass-associated foraminiferal fauna at Ninemile Bank and Trout Cove. Trout Cove, the closest site to the mainland, contains sparse seagrass beds due to its long-term, low-salinity environment (J. Fourqurean, oral communication, 2008). Ninemile Bank, strongly influenced by the Gulf of Mexico, had a greatly damped pattern of decrease followed by a small increase. This agrees with Fourqurean's observation (oral communication, 2008) that no great loss in seagrass abundance was observed at Ninemile Bank between 1987 and 1994. Thus, it is reasonable that great changes in seagrassassociated foraminiferal percentages in these two areas were not recorded. 
The seagrass-associated benthic foraminiferal species with relative high percentages overall are Q. polygona, Q. subpoeyana, T. rotunda, B. eburnea and P. dilatata, which all showed great changes in percent abundance during the late 1980s and early 1990s in the Bob Allen Bank and Russell Key cores. Of these species, $P$. dilatata seems to be the best species at distinguishing the seagrass dieoff in these cores. If the bioturbation effect and

its related error of ${ }^{210} \mathrm{~Pb}$ dating of \pm 2 years is considered, the percentages of the seagrassassociated foraminiferal patterns are fairly similar. Furthermore, the cluster analyses (Figs. 2.2-2.7) of these data generally divided the samples into three successive groups: 1970 to the early 1980s, the middle 1980s to early 1990s (seagrass dieoff) and the late 1990s (seagrass recovery). A discriminant analysis $(\mathrm{p}<0.0001)$ of these data can also distinguish these three periods (Figure 2.9). Therefore, these species are potentially good seagrass abundance indicators. They have been applied to interpreting Florida Bay's seagrass history over the last 120 years at a decadal scale and over the last 4,000 years at a centennial - millennial scale.

\section{Historical Seagrass Abundance, 1880-2001}

Analyses of variance are used to test whether seagrass-associated foraminiferal percentages changed significantly in accordance with documented anthropogenic and environmental events (Table 2.4), such as agricultural activity, canal and railway construction, south Florida water management and the 1987-1994 seagrass dieoff. All of the studied samples within each core were assigned to six main intervals (Table 2.4) based on the events that occurred between 1880 and 2001. Note that on this longer time 
scale, ${ }^{210} \mathrm{~Pb}$ ages have an approximate error of \pm 5 years (email communication, Charles Holmes, 2008).

(1) Bob Allen Bank Core \#0206122. As with the study of the seagrass dieoff period (above), the most abundant seagrass-associated foraminiferal species are B. eburnea, $P$. dilatata, Q. subpoeyana and T. rotunda (Figure 2.10). The percent abundance of $B$. eburnea fluctuated through this period and had a maximum at 1948. The abundance of $T$. rotunda remained fairly steady over the past century except for a short period between 1987 and 1996, the lowest values. A large decrease in the percent abundance of $Q$. subpoeyana dated between 1901 and 1919, after which it remained relatively steady. The abundance of $P$. dilatata was mostly steady until 1987-2001, when it had its lowest values. Qinqueloculina polygona, Q. subpoeyana and $P$. dilatata experienced a concurrent minimum around 1913.

The cluster analysis (Figure 2.10) groups the samples into two main intervals: $78-38 \mathrm{~cm}$ (1889-1948), and 34-2 cm (1954-2001). The ANOVA (Figure 2.11) results indicate that Interval 2 is significantly different from others, and that the changes between intervals are not significant overall $(\mathrm{p}=0.36)$.

(2) Bob Allen Core \#0206124. The most abundant seagrass-associated foraminiferal species are B. eburnea, T. rotunda, Q. polygona, Q. subpoeyana and P. dilatata (Figure 2.12). Following a relatively low abundance before 1900, B. eburnea increases to a maximum at 1910-1915, and has lower values until 1965, when it has its highest values. Triloculina rotunda and $Q$. polygona experienced less extreme fluctuations. The percent abundance of $Q$. subpoeyana peaked about every 30 years. Paeteoris dilatata shows its largest declines at 1905 and 1949. The cluster analysis (Figure 2.12) separates the 
samples into two major groups: 40-32 cm (1883-1905), and 30-2 cm (1910-1987). The ANOVA (Figure 2.13) results no significant difference overall between intervals $(p=0.31$ ).

(3) Russell Key Core \#0206125. The most abundant seagrass-associated foraminiferal species are B. eburnea, Q. polygona, Q. subpoeyana, P. dilatata and T. rotunda (Figure 2.14). The abundance of B. eburnea is greatest between 1884 and 1964, after which it occurs at about half the percentage. Triloculina rotunda and $P$. dilatata are mostly absent until around 1915-1918, after which they fluctuate with minor amplitude. The percent abundances of $Q$. polygona and $Q$. subpoeyana fluctuate with low amplitude without any obvious large changes.

The cluster analysis (Figure 2.14) divides the samples into two major groups: 140-46 cm (1884-1964) and 42-2 cm (1967-2001). Within the lower cluster, there are two groups: 140-104 cm (1884-1915) and 100-46 cm (1918-1964). Analysis of Variance (Figure 2.15) results indicate that that the changes in percent abundances of seagrass-associated foraminifera are not significant overall $(\mathrm{p}=0.334)$. However, Intervals $1-3$ are significantly different from Interval $5(\mathrm{p}=0.04)$, but not significantly different from Interval $6(\mathrm{p}=0.18)$

(4) Russell Key Core \#0206127. The most abundant seagrass-associated foraminiferal species are B. eburnea, Q. polygona, Q. subpoeyana, $P$. dilatata and T. rotunda (Figure 2.16). The percent abundances of B. eburnea and $Q$. subpoeyana remained high during the 1940s and early 1950s, declined during the 1960s and 1970s, increased again during the early 1980s, and dramatically decreased around 1989. The percent abundances of $T$. rotunda and Q. polygona were relatively low between 1938 and 1953, gradually increased to their maximum values between 1977 and 1981, and then dropped to a period 
low levels 1988-2001. Paeteoris dilatata occurred at relatively low values except during the years 1955-1974.

The cluster analysis (Figure 2.16) clearly divides the samples into two main groups: 148-124 cm (1919-1932) and 112-2 cm (1938-2001). The upper cluster further groups samples into two subclusters: $112-26 \mathrm{~cm}(1938-1988)$ and $24-2 \mathrm{~cm}$ (1989-2001).

An ANOVA (Figure 2.17) shows that the percent abundances of seagrass-associated foraminifera are significantly different between intervals overall $(p<0.0001)$. In particular, Intervals 3-4 are significantly different from Intervals 5-6 $(\mathrm{p}=0.001)$.

There are similar patterns in these Russell Key cores if the approximate error of age dating of \pm 2 years for the past 30 years and \pm 5 years before that are considered. Both cluster analyses (Figs. 2.14 and 2.16) show a lower cluster of the early 1940's to around 1960 , a middle cluster of the 1960 's to early 1980 's, and an upper cluster of the mid1980 s to 2001 , with the late 1980 's to early 1990 's as a subgroup.

The ANOVAs (Figs. 2.15 and 2.17) show different results in the two cores, but with some similar patterns. In core $\# 0206125$, no significant changes between any two adjacent intervals and the fact that Intervals 1, 2 and 3 are significantly different from Interval 5, with Interval 4 having an intermediate value, suggest a gradual change. In core $\# 0206127$, the difference between Intervals 3-4 and 5-6 is more extreme ( $<<0.00001)$. In both cores, Intervals 3 and 4 are significantly higher than Intervals 5 and 6 .

(5) Ninemile Bank Core \#0208134. The most abundant seagrass-associated foraminiferal species are B. eburnea, T. rotunda, Q. subpoeyana and P. dilatata (Figure 2.18). Biloculina eburnea and $P$. dilatata have similar trends; values were relatively high between 1885 and 1919, less 1927-1956, and lowest thereafter. The percent abundances 
of $T$. rotunda and $Q$. subpoeyana were relatively low until 1940, after which they show similar fluctuations.

The cluster analysis (Figure 2.18) divides the samples into two major groups: $90-64 \mathrm{~cm}$ (1885-1919), and 58-2 cm (1927-2001). Within the first cluster, there are two subclusters: 90-86 cm (1885-1890) and 82-64 cm (1895-1919). The second cluster contains two subclusters: 58-36 cm (1927-1956) and 32-2 cm (1962-2001).

An ANOVA (Figure 2.19) shows that the percent abundances of seagrass-associated foraminifera between intervals are significantly different overall $(\mathrm{p}=0.004)$. This is because Intervals 1 and 2 are much higher than Intervals 3, 4, 5 and 6.

(6) Trout Cove Core \#02061211. The only abundant seagrass-associated foraminiferal species at this site were T. rotunda and Peneroplis proteus (Figure 2.20), although $P$. proteus was absent before the 1930s and its average percent abundance was generally low. Following a period of relatively low abundance between 1880 and 1922, T. rotunda increased to a maximum at 1969 and remained abundant until 1994 (the age of the core top).

The cluster analysis (Figure 2.20) separates the samples into two major groups: 46-20 cm (1880-1948) and 18-2 cm (1953-1994). An ANOVA (Figure 2.21) shows no significant difference overall in the percent abundances of seagrass-associated foraminifera between intervals $(\mathrm{p}=0.68)$. Changes between any two intervals are also not significant $(\mathrm{p}>0.05)$.

(7) Trends in Seagrass-Associated Foraminifera. Trends in species' abundances and the total percentages of seagrass-associated foraminifera against time (Figure 2.22) are discussed below. The percentages of seagrass-associated benthic foraminiferal patterns 
(Figure 2.22) from both cores at Bob Allen Bank show similar fluctuations except for the value at 1948 (when core \#0206122 has an anomalously high peak). They both show relatively low abundances around 1905, 1940, and 1987-2001.

The curves of the percentages of seagrass-associated foraminifera for Russell Key (Figure 2.22) show a large drop around 1938 in both cores. Furthermore, the overall pattern of fluctuations is similar: high values during 1919-1935, a low at 1938, recovery to a high around 1948, and a similar pattern at a finer scale from 1972-2001 if an error of age dating of \pm 2 years is considered.

At Ninemile Bank (Figure 2.22) the main shift in percentages of seagrass-associated foraminifera was a dramatic drop around 1930. Before this, between 1885 and 1932, the percentages were relatively high with high-amplitude shifts. Afterwards, the values changed to low percentages and low-amplitude fluctuations.

The results for percentages of seagrass-associated benthic foraminifera suggest that oscillations have been minor at Trout Cove relative to the other sites over the last century (Figure 2.22). Trout Cove values are also generally lowest of all sites.

A discriminant analysis was done to distinguish any geographic (site-related) patterns in seagrass foraminifera, and identify any differences in pre-agriculture (1880-1905) versus human-influenced (after 1905) intervals of time. The results (Figure 2.23) show that Ninemile Bank $(\mathrm{N})$ and Trout Cove $(\mathrm{T})$ samples are easily discriminated from a more closely related group of the central bay (Bob Allen Bank and Russell Key) samples. The two time intervals can only be differentiated within the Ninemile Bank and the Trout Cove samples, where N1 samples generally lie to the right of N2 samples, and T1 samples are generally lower than T2 samples. 


\section{Long-term Seagrass Abundance, Over the Past 4000 Years}

In addition to the more recent seagrass changes, the long-term fluctuations were investigated to identify any major ecosystem changes. Around 4000 years ago, when seawater entered the bay, mangroves were gradually replaced by seagrass beds. For this purpose, the longest core that included basal mangrove peat, the Ninemile Bank core, was dated with ${ }^{14} \mathrm{C}$ and analyzed for foraminifera.

The most abundant seagrass-associated foraminifera are B. eburnea, T. rotunda, $Q$. subpoeyana and P. dilatata (Figure 2.24). Biloculina eburnea and P. dilatata have similar patterns with their highest period of abundance between 106 and $56 \mathrm{~cm}$. In constrast, $Q$. subpoeyana shows its highest relative abundances between $186-90 \mathrm{~cm}$. Triloculina rotunda becomes more abundant and less fluctuating in the samples between 136 and 0 $\mathrm{cm}$.

The cluster analysis (Figure 2.24) clearly divides the samples into two major time clusters: 242-94 cm (ca. B.P. 3500 - A.D. 1884) and 90-2 cm (ca. A.D. 1884 - 2001). Within the first cluster, there are two subclusters: $242-182 \mathrm{~cm}$, and $178-94 \mathrm{~cm}$. Within the second cluster, there are also two subclusters: $90-64 \mathrm{~cm}$ and $58-2 \mathrm{~cm}$.

Over the last $\sim 4000$ years, a gradual increase in percentages of seagrass-associated foraminifera between 242 and $64 \mathrm{~cm}$ followed by a sudden decrease between 64 and 54 cm can be observed (Figure 2.25). An ANOVA (Figure 2.26) was used to test for significance of these changes. The five intervals A-E (all ages approximate) were defined based on visual inspection of Figure 25: (A) before B.P. 3800 - B.P. 3530, (B) between B.P. 3800 - B.P. 2920, (C) A.D. 2920 - A.D. 1800, (D) A.D. 1800 -1930, and (E) A.D. 1930 - 2001. The ANOVA shows the changes in seagrass abundance between intervals 
are significantly different overall $(\mathrm{p}<0.001)$, showing an increase to Interval $\mathrm{D}$, then a decline to E.

The percentages of seagrass-associated foraminifera for all studied Ninemile Bank samples (Figure 2.25) indicate that the seagrass abundance is nearly zero for the two bottom samples, which were taken within sediments mixed with the basal mangrove peat. Values increase gradually from ca. B.P. 3500 to B.P. 2300 and faster to around ca. A.D. 180. Following the highest value around 1880-1930, there was an enormous drop around A.D. 1930, after which values remained low until A.D. 2001 (Figure 2.25). Moreover, the pattern also shows a period of low-amplitude shifts between ca. B.P. 3500 and ca. B.P. 2300 that changes to high amplitude between ca. B.P. 2300 and ca. A.D. 1930, then back to low amplitude between ca. A.D. 1930 and ca. A.D. 2001.

\section{Discussion}

The following interpretations are based on the total percentages of seagrass-associated foraminifera and cluster and discriminant analyses of whole assemblages, instead of any one species, because no single taxon behaved similarly in all cores. The switch in abundance of a single taxon may be the result of fairly localized changes in food, salinity, or other environmental factors, while the total percentages of seagrass-associated foraminifera should generally reflect the abundances of seagrass, as tested against the recent seagrass dieoff (section 1, below). 


\section{Recent Seagrass Dieoff, 1970-2001}

The four cores from Bob Allen Bank and Russell Key represent the record from the central bay (Figure 2.8). Most relatively abundant seagrass-associated species in the Bob Allen Bank core \#0206122 show an obvious decrease in abundance in correspondence to the seagrass dieoff, followed by a slight recovery afterwards. This agrees with the fact that the seagrass abundance of Florida Bay dramatically decreased in the central bay between 1987 and 1994 (Hall et al., 1999), and has started to recover since then in the central bay (Fourqurean et al., 2002). Before the seagrass dieoff, Russell Key core \#0206127 increased, and Russell Key core \#0206125 and Bob Allen core \#0206122 fluctuated, although Bob Allen core \#0206124 decreased along with decreasing values of seagrass biomarkers during this time (Xu et al., 2007). This pattern suggests that the total percentage of seagrass-associated foraminifera can be used as an indicator for seagrass abundance at Bob Allen Bank. Since the top 2-cm sample in Core \#0206124 is dated at 1987, presumably due to erosion, no data are available from here on the seagrass dieoff. However, the gradual drop in the total percentages of seagrass-associated foraminifera during the 1980s suggests that environmental stresses on seagrass and its related species increased prior to the dieoff.

At Russell Key during the late 1980s-early 1990s, the dramatic drop in core \#0206125, and to a much lesser extent in core \# 0206127, indicates that these species responded to the seagrass dieoff by declines relative to the total foraminiferal community. After 1995, the percentages of seagrass-associated foraminifera slightly increased, indicating that seagrass abundance gradually recovered. This agrees with the fact that the seagrass dieoff 
ended around 1995 and started to recover since then in the central bay (Durako et al., 2002).

Ninemile Bank is farthest from both the mainland and the Florida Keys and exchanges water directly with the Gulf of Mexico. Therefore, it should have been the least affected by anthropogenic activities. The percent abundances of seagrass-associ ated benthic foraminifera show a slight decrease at the dieoff interval and an increase afterwards, which agrees with the prediction of a damped response. Because of the connectedness of foraminiferal populations across the bay, a dieoff of seagrass in the central bay should affect the outer bay to some extent. This pattern also agrees with the fact that Ninemile Bank experienced little seagrass loss (oral communication, James Fourqurean, 2008). Furthermore, surveys of seagrass abundance at Ninemile Bank between 1984 and 1994 showed that stations had records of stable standing crops of T. testudinum (50-216 g dry weight $/ \mathrm{m}^{2}$ ), except for only a few stations that recorded a slight decrease (from a range of 50-216 to 1-125 g dry weight $/ \mathrm{m}^{2}$; Hall et al., 1999). The increase of abundance of seagrass-associated species is most likely the result of species' migrations from other sites where environmental stress is fairly high, such as Rabbit Key, where a great amount of seagrass died between 1987 and 1994 (Hall et al., 1999).

Trout Cove, the site closest to the mainland, receives much freshwater and is a lowsalinity environment with a currently sparse abundance of seagrass. Therefore, unlike the foraminiferal response in the central bay and the damped response from the outer bay, no large changes in percent abundance of seagrass-associated foraminiferal species were observed in this area. This agrees with the observation of no seagrass dieoff at Duck Key, which is fairly close to Trout Cove (Ziemen et al., 1999), and with a seagrass biomarker 
study (Xu et al., 2007) that suggested less effect of the seagrass dieoff in this area relative to other Florida Bay sites.

In summary, nearly all seagrass-associated foraminifera from the central bay Bob Allen and Russell Key cores show declines during the seagrass dieoff period if the error of age dating of \pm 2 years is incorporated. Moreover, the total percentages of seagrass-associated foraminifera also show a large drop in the cores from the central bay during the seagrass dieoff period. The results of this test of the foraminiferal response against a welldocumented event indicate that these species, taken as a whole in the form of percentage of seagrass-associated foraminifera, are good indicators of seagrass abundance.

\section{Historical Seagrass Abundance, 1880-2001}

As with the study of the seagrass dieoff, the changes in total percent abundances of seagrass-associated foraminifera, including cluster and discrminant analyses, are analyzed instead of individual taxa. At this decadal time scale (using an approximate age error of \pm 5 years), the pattern of percentages of seagrass-associated foraminifera in the Bob Allen Bank cores behaved more similarly than over the $\sim 30$ years from 1970-2001 (section 1, above). The difference between these two cores, which are only $100 \mathrm{~m}$ apart, may be explained by local habitat differences, which can be partly seen in their sediment accumulation rates (Table 2.5) -- one is almost twice as fast as the other.

Below, the historical changes in seagrass abundance will be discussed by the intervals defined in Table 2.4. Florida Bay was a natural ecosystem before 1905 (Interval 1). During this interval, between 1890 and 1895 percentages of seagrass-associated foraminifera peaked at relatively high values in all five cores (Figure 2.22), indicating 
high seagrass abundance. This pattern is supported by the research of Cronin et al. (2001), who found that Malzalla floridana, an ostracode species preferring Thalassia as a habitat, was also more abundant before 1905 than afterwards.

The results (Figure 2.23) of discriminant analysis show that Ninemile Bank and Trout Cove samples are easily discriminated from a more closely related group of the central bay samples. This indicates that the central bay has been much different from the northeast bay next to the mainland and western bay near the Gulf of Mexico. The central bay samples from before and after human settlement show no overall trend with time. However, the two time intervals can be differentiated within the Ninemile Bank samples and within the Trout Cove samples, suggesting somewhat different seagrass abundances before and after humans began agricultural and construction activities.

Between 1910 and 1920, which is within Interval 2 (Table 2.4), the percentages of seagrass-associated foraminifera decreased. The decreases indicate a seagrass decline, which corresponds to the construction of the Flagler Railroad in the Florida Keys between 1905 and 1912. Swart et al. $(1996,1999)$ suggested that the railroad restricted the circulation of water and blocked water exchange with the Gulf of Mexico to central Florida Bay, leading to hypersalinity and the buildup of organic matter. Hypersalinity results in sparse seagrass abundance because it can only tolerate a narrow range, between 30 and 40 psu (Montague and Ley, 1993; Kahn and Durako, 2006). Buildup of organic matter may also result in low values of dissolved oxygen, which in more extreme cases can be lethal to seagrass. Trout Cove is the study site farthest from the Florida Keys and would have been less affected by the interruption of water exchange between the Atlantic Ocean and Florida Bay caused by the construction of the Flagler Railroad (Swart et al., 
2001). Seagrass abundance between the 1910s and the 1920s at Trout Cove remained relatively low and stable, indicating a fairly different environment from any other periods (Figure 2.22), which corresponds to the time of construction of canals and levees for agricultural use, between 1915 and 1929 (Light and Dineen, 1994), when freshwater that originally flowed into Florida Bay was diverted into the Atlantic Ocean. The changes of freshwater flow have led to other environmental changes, which might have affected the seagrass abundance.

The largest change seen in all cores except Trout Cove occurred during the 1930s and 1940s. This corresponds to a multi-year drought (within Interval 3) in the early 1940s in south Florida, resulting in hypersalinity in the bay (Swart et al., 1999). The central bay receives less freshwater input from the Everglades, and therefore the salinity in these parts relates more directly to precipitation (Swart et al., 2001). According to previous studies of salinity proxies, the multiyear drought during this period led to hypersalinity in these parts of the bay (Dwyer and Cronin, 2001, Swart et al., 1999), which may have contributed to the great seagrass loss at Bob Allen Bank and Russell Key. The perceived loss of seagrass during the 1930s at Bob Allen Bank agrees in part with the results of a seagrass biomarker study that suggested a sudden drop from 1932 to 1949 (Xu et al., 2007). The enormous drop in seagrass abundance at Ninemile Bank in southwestern Florida Bay might relate less to the drought because the site is further from sources of freshwater, but is still supported by the results of the biomarker study (Xu et al., 2007). Another sudden drop in seagrass abundance in the 1950s occurred again in all cores except the Trout Cove core. This decrease may have been caused by a multi-year drought in the 1950s which resulted in hypersalinity up to $70 \mathrm{psu}$ (Fourqurean and Robblee, 1999). 
This sudden drop also agrees with previous research (Cronin et al., 2001) which shows a great decrease in Malzella floridana, an ostrocade species preferring living on seagrass, during the 1940s and 1950s. Multiyear droughts in the 1940s - 1950s might ultimately be related to Atlantic Multidecadal Oscillation (AMO) warm phases (Enfield et al., 2001), during which less rainfall is expected.

In any case, the gradual decrease in seagrass abundance between 1970 and 1985 in the cores from Bob Allen Bank, Ninemile Bank and Trout Cove, and Russell Key Core \#0206127, suggest a generally stressful environment for seagrass. The decrease might be attributed to the mass construction of canals, levees and water retention areas (Light and Dineen, 1994), which greatly affected freshwater flow into the bay. Russell Key Core \#0206127 did not show this change and actually peaked, but then rapidly decreased beginning at $\sim 1987$ when the seagrass dieoff began. Despite this decrease, the percentages of seagrass-associated foraminifera remained fairly low at Ninemile Bank and Trout Cove. Ninemile Bank, located in western Florida Bay, would have been much less affected by changes in the freshwater runoff from the mainland. Reasons for the enormous drop at Ninemile Bank from higher levels around 25\% to the low seagrass abundance around 10\% in this area since 1930 are unknown, although perhaps the $\sim 1920$ high outlier is an anomaly for the general area, in which case a decreasing trend since $\sim 1908$ may have been caused by construction of the railroad in the keys. The low seagrass abundance in Trout Cove in this interval was probably due to the continued large freshwater input, which is not suitable for seagrass growth. The percentages of seagrassassociated foraminifera in Intervals 5 and 6 were discussed in section IV.1., above. 


\section{Long-term Seagrass Abundance, Over the Past $\sim 4000$ Years}

Seagrass abundance on the centennial to millennial to scale was examined to assess whether human-induced changes seen at the 120 -year scale were comparable to natural variability. For this purpose, the longest core from Ninemile Bank, which is as old as the mangrove peat at the base, was analyzed. Seawater began to cover the area of Florida Bay around 4000 years ago (Wanless and Tagett, 1989). Before that, Florida Bay was dominated by mangroves and freshwater, similar to the present-day Everglades. This clearly explains the near absence of seagrass in the two bottom samples (Figs. 2.24, 2.25), which included the basal mangrove peat (Holmes, written communication, 2004). During the subsequent sea level rise, Florida Bay gradually became a more hospitable habitat for seagrass, indicated by a gradual increase between ca. B.P. 3800 and ca. A.D. 1930. The CONISS cluster analysis (Figure 2.24) shows that the largest change occurred at $\sim$ A.D. 1880, when seagrass abundance dramatically increased. Another change occurred around B.P. $3360-3200$ (Figure 2.24) when seagrass abundance reached its minimum and began to rise, as indicated by the percentages of seagrass-associated foraminifera.

The ANOVA of Ninemile Bank (Figure 2.26) confirms that the changes in seagrass abundance between the intervals defined on the basis of percentages of seagrassassociated foraminifera are significant through time. These results indicate that mangroves disappeared from Ninemile Bank after seawater entered the bay, and the saline water became gradually suitable for seagrass growth. Values between ca. 38002920 B.P. are around 5\%, similar to present-day values of Trout Cove (Figure 2.22), and thus interpreted to be next to the mainland. The prominent fluctuations in amplitude between ca. A.D. 1884 and ca. A.D. 1930, much greater than before or afterwards, and 
the dramatic drop in values thereafter, suggest that environmental stress was relatively high, with the seagrass assemblages largely dominated by two species (B. eburnea and $P$. dilatata), before returning to the low-amplitude fluctuations that continued until 2001.

\section{Conclusions}

Benthic foraminifera generally are tolerant of short-term perturbations in their environment, although they respond to seasonal and annual changes. The fact that the total percentages of seagrass-associated foraminifera responded well to the seagrass dieoff in the central bay where severe seagrass loss occurred over about six years indicates that these species can be regarded as reliable indicators of larger, longer term changes in seagrass abundance recorded in sediments.

Seagrass abundance fluctuated differently from core to core, even within sites, but some general patterns were observed. As expected, seagrass abundance was historically low and showed few fluctuations at Trout Cove because the salinity has been too low for seagrass to thrive. Ninemile Bank switched in seagrass abundance from relatively high to low levels around 1920 through the 1930s, with the last (2001) values comparable to the central bay. Reasons for this significant drop are unknown, but if one extremely high point is anomalous for the area, it is possibly related to the construction of the Flagler railroad through the Florida Keys. The Bob Allen Bank and Russell Key sites in the central bay behaved similarly. The results show low seagrass abundance during the periods of 1905-1920 and 1940-1960, attributed to the human activities caused by the construction of the Flagler Railroad and canals between 1905 and 1928, and hypersalinity from the multiyear drought during the 1940s, possibly caused by AMO warm phases. 
On a longer time scale, seagrass at Ninemile Bank was seen to appear around 38003530 years ago and gradually increase in abundance until the early 1900s. The reason that seagrass beds became denser as indicated by the data may be attributed to the rising sea level and its related effects, because seagrass prefers a normal marine environment. After the drop in the early 1900s, seagrass abundance fluctuated with more minor amplitude. However, the relatively low levels of seagrass abundance at Ninemile Bank under normal marine conditions since around 1930 suggest long-term environmental stress in Florida Bay. 


\section{REFERENCES}

Bock, W. D., 1969, Thalassia testudinum, a habitat and means of dispersal for shallow water benthonic foraminifera: Gulf Coast Association of Geological Societies

Transactions, v. 19, p. 337-340.

Bock, W. D., Lynts, G. W., Smith, S., Wright, R., Hay, W. W., and Jones, J. I., 1971, A symposium of recent south Florida foraminifera: Miami Geological Society, Memoir I, $245 \mathrm{pp}$.

Boyer, J. N., Fourqurean, J. W., and Jones, R. D., 1999, Seasonal and long-term trends in the water quality of Florida Bay (1989-1997): Estuaries, v. 22, p. 417-430.

Brasier, M. D., 1975, Ecology of recent sediment-dwelling and phytal foraminifera from the lagoons of Barbuda, West Indies: Journal of Foraminiferal Research, v. 5, p. 42-61.

Brewster-Wingard, G. L., and Ishman, S. E., 1999, Historical trends in salinity and substrate in central Florida Bay: a paleoecological reconstruction using modern analogue data: Estuaries, v. 22, p. 369-383.

Butler, M. J., Hunt, J. H., Herrnkind, W. F., Childress, M. J., Bertelsen, R., Sharp, W., Matthews, T., Field, J. M., and Marshall, H. G., 1995, Cascading disturbances in Florida Bay, USA: Cyanobacterial blooms, sponge mortality, and implications for juvenile spiny lobsters Panulirus argus: Marine Ecology Progress Series, v. 129, p. 119-125.

Buzas, M. A., and Severin, K. P., 1982, Distribution and systematics of foraminifera in the Indian River, Florida: Smithsonian Contributions to the Marine Sciences, no. 16, 45 pp.

Carlson, P. R., Yarbro, L. A., and Barber, T. A., 1994, Relationship of sediment sulfide to mortality of Thalassia testudinum in Florida Bay: Bulletins of Marine Science, v. 54, p. 733-746.

Collins, L. S., 1993, Neogene paleoenvironments of the Bocas Del Toro Basin, Panama: Journal of Paleontology, v. 67, p. 699-710.

Collins, L. S., Schultz, S., and Fourqurean, J. W., 2004, Use of seagrass-associated foraminifera as indicators of past water quality: Geological Society of America Annual Meeting, Abstracts with Programs, v. 36, no. 5, p. 382.

Cronin, T. M., Holmes, C. W., Wingard, G., Ishman, S., Dowsett, H., and Waibel, N., 2001, Historical trends in epiphytal ostracodes from Florida Bay: Implications for seagrass and macro-benthic algal variability: Bulletins of American Paleontology, v. 361, p. $159-197$. 
Durako, M. D., and Kuss, K. M., 1994, Effects of Labyrinthula infection on the photosynthetic capacity of Thalassia testudinum: Bulletins of Marine Science, v. 54, p. 727-732.

Durako, M. J., Hall, M. O., and Merello, M., 2002, Patterns of change in the seagrass dominated Florida Bay hydroscape: The Everglades, Florida Bay, and Coral Reefs of the Florida Keys: An Ecosystem Sourcebook, (eds. Porter, J. W., and Porter, K. G.), CRC Press, Boca Raton, Florida, pp. 523-537.

Dwyer, G. S., and Cronin, T. M., 2001, Ostracode shell chemistry as a paleosalinity proxy in Florida Bay: Bulletins of American Paleontology, v. 361, p. 249-276.

Ellis, B. F., and Messina, A. R., 1941-2009, Catalogue of Foraminifera, v. 106, 87,000 pp, online: Micropaleontology Press, N.Y.

Enfield, D. B., Mestas-Nunez, A. M., and Trimble, P. J., 2001, The Atlantic multidecadal oscillation and its relation to rainfall and river flows in the continental U. S.: Geophysical Research Letters, v. 28, p. 2077-2080.

Engelman, L., 2004, Discriminant analysis: SYSTAT 11, Statistics I, p. 301-358.

Enos, P., 1989, Islands in the bay — a key habitat of Florida Bay: Bulletins of Marine Science, v. 44, p. 365-386.

Fourqurean, J.W., Jones, R.D., and Zieman, J.C., 1993, Processes influencing water column nutrient characteristics and phosphorus limitation of phytoplankton biomass in Florida Bay, FL, USA: Inference from spatial distributions: Estuarine Coastal and Shelf Science, v. 35, p. 295-314.

Fourqurean, J. W., and Robblee, M. B., 1999, Florida Bay: a history of recent ecological changes: Estuaries, v. 22, p. 345-357.

Fourqurean, J. W., Durako, M. J., Hall, M. O., and Hefty, L. N., 2002, Seagrass distribution in south Florida: a multi-agency coordinated monitoring program: The Everglades, Florida Bay, and Coral Reefs of the Florida Keys: An Ecosystem Sourcebook, (eds. Porter, J. W., and Porter, K. G.), CRC Press, Boca Raton, Florida, p. 497-522.

Fujita, K., and Hallock, P., 1999, A comparison of phytal substrate preferences of Archaias angulatus and Sorites orbiculus in mixed macroalgal-seagrass beds in Florida Bay: Journal of Foraminifera, v. 2, p. 143-151.

Grimm, E.C., 1987, CONISS: a Fortran 77 program for stratigraphically constrained cluster analysis by the method of incremental sum of squares: Computers and Geoscience, v. 13, p. $13-25$. 
Hall, M. O., Durako, M. J., Fourqurean, J. W., and Zieman, J. C., 1999, Decadal changes in seagrass distribution and abundance in Florida Bay: Estuaries, v. 22, p. 445-459.

Halley, R. B., and Rouler, L. M., 1999, Reconstructing the history of eastern and central Florida Bay using mollusk-shell isotope records: Estuaries, v. 22, p. 358-368.

Holmes, C. W., Robbins, J., Halley, R., and Bothner, M., 2001, Sediment dynamics of Florida Bay mud banks on a decadal time scale: Bulletins of American Paleontology, v. 361, p. 31-40.

Kahn, A. E., and Durako, M. J., 2006, Thalassia testudinum seedling responses to changes in salinity and nitrogen levels: Journal of Experimental Marine Biology and Ecology, v. 335, p. 1-12.

Lapointe, B. E., and Clark, M. W., 1992, Nutrient inputs from the watershed and coastal eutrophication in the Florida Keys: Estuaries, v. 15, p. 465-476.

Light, S. S., and Dineen, W. J., 1994, Water control in the Everglades: a historical perspective, in Everglades: The Ecosystem and Its Restoration, (eds. Davis, S. M., and Ogden, J. C.), St. Lucie Press, Delray Beach, Florida, pp. 47-84.

Lirman, D., and Cropper, W. P., 2003, The influence of salinity on seagrass growth, survivorship and distribution within Biscayne Bay, Florida: field, experimental, and modeling studies: Estuaries, v. 26, p. 131-141.

Martin, R. E., and Wright, R. C., 1988, Information loss in the transition from life to death assemblages of foraminifera in back reef environments, Key Largo, Florida: Journal of Paleontology, v. 62, p. 399-410.

McMillan, C., and Moseley, F. N., 1967, Salinity tolerance of five marine spermatophytes of Redfish Bay, Texas: Ecology, v. 48, p. 503-506.

Montague, C. L., and Ley, J. A., 1993, A possible effect of salinity fluctuation on abundance of benthic vegetation and associated fauna in northeastern Florida Bay: Estuaries, v. 16, p. 703-717.

Murray, J. W., 1991, Ecology and Palaeoecology of Benthic Foraminifera: Palaeontological Association, 397 pp.

Richardson, S. L., 2000, Epiphytic foraminifera of the Pelican Cays, Belize; diversity and distribution, The Natural History of the Pelican Cays: Atoll Research Bulletin, (eds. Macintyre, I. B., and Rutzler, K.), v. 475: 208-228.

Rose, R. P., and Lidz, B. H., 1977, Diagnostic foraminiferal assemblages of shallowwater modern environments: south Florida and the Bahamas: Sedimenta VI, $55 \mathrm{pp}$. 
Schmidt, T. W., 1979, Ecological study of fishes and water quality characteristics of Florida Bay, South Florida Research Center, Everglades National Park, Homestead, Florida, USA, $40 \mathrm{pp}$.

Steinker, P. J., and Steinker, D. C., 1976, Shallow-water foraminifera, Jewfish Cay, Bahamas: Marine Sedimentology Special Publication, v. 1, p. 171-180.

Stuiver, M., Reimer, P. J., Bard, E., Beck, J. W., Burr, G. S., Hughen, K. A., Kromer, B., McCormac, G., Van, D. P. J., Spurk, M., 1998, INTCAL98 radiocarbon age calibration, 24,000-0 cal B.P., Radiocarbon 40, v. 30, p. 1041-1083.

Swart, P. K., Healy, G., Dodge, R. E., Kramer, P., Hudson, H., Halley, R., and Robblee, M., 1996, The stable oxygen and carbon isotopic record from a coral growing in Florida Bay: A 160 years record of climate and anthropogenic influence: Palegeography Paleoclimatology Paleoecology, v. 123, p. 219-237.

Swart, P. K., Healy, G., Greer, L., Saied A., Anderegg, D., Dodge, R. E., 1999, The use of proxy chemical records in coral skeletons to ascertain past environmental conditions in Florida Bay: Estuaries, v. 22, p. 384-397.

Swart P. K., Price, R. M., and Greer, L., 2001, The relationship between stable isotopic variations $(\mathrm{O}, \mathrm{H}$, and $\mathrm{C})$ and salinity in waters and corals from environments in South Floirda: implications for reading the paleoenvironmental record: Bulletins of American Paleontology, v. 361, p. 17-30.

Talma, A. S., and Vogel, J. C., 1993, A simplified approach to calibrating 14C dates, Radiocarbon 35, v. 2, p. 317-322.

Tomasko, D. A., Dawes, C. J., and Hall, M. O., 1996, The effect of anthropogenic nutrient enrichment on turtle grass (Thalassia testudinum) in Sarasota Bay, Florida: Estuaries, v. 19, p. 448-456.

Wanless, H. R., and Tagett, M. G., 1989, Origin, growth and evolution of carbonate mudbanks in Florida Bay: Bulletins of Marine Science, v. 44, p. 454-489.

Wantland, K. F., 1967, Recent Foraminifera of the British Honduras Shelf: unpublished Ph.D. dissertation, Rice University, Houston, Texas, 125 pp.

Xu, Y., Holmes, C. W., and Jaffe, R., 2007, Paleoenvironmental assessment of recent environmental changes in Florida Bay, USA: A biomarker based study: Estuarine, Coastal and Shelf Science, v. 73, p. 201-210.

Zieman, J. C., Fourqurean, W. J., and Iverson, R. L., 1989, Distribution, abundance and productivity of seagrasses and macroalgae in Florida Bay: Bulletins of Marine Science, v. 44, p. 292-311. 
Zieman, J. C., Fourqurean, J. W., and Frankovich, T. A., 1999, Seagrass die-off in Florida Bay: long-term trends in abundance and growth of turtle grass, Thalassia testudinum:

Estuaries, v. 22, p. 460-470. 
Table 2.1 Description of coring sites examined in this study. Cores were split into 2-cm samples.

\begin{tabular}{|c|c|c|c|c|}
\hline Site & $\begin{array}{l}\text { Latitude } \\
\text { (N) }\end{array}$ & $\begin{array}{l}\text { Longtitude } \\
\text { (W) }\end{array}$ & $\begin{array}{l}\text { Core } \\
\text { length }\end{array}$ & $\begin{array}{l}\text { Water } \\
\text { depth }\end{array}$ \\
\hline $\begin{array}{l}\text { Bob Allen } \\
\text { Bank Core } \\
\# 0206122\end{array}$ & $\begin{array}{l}25^{\circ} \\
01.670^{\prime}\end{array}$ & $80^{\circ} 40.871^{\prime}$ & $200 \mathrm{~cm}$ & $48 \mathrm{~cm}$ \\
\hline $\begin{array}{l}\text { Bob Allen } \\
\text { Bank Core } \\
\# 0206124\end{array}$ & $\begin{array}{l}25^{\circ} \\
01.731^{\prime}\end{array}$ & $80^{\circ} 40.795^{\prime}$ & $194 \mathrm{~cm}$ & $48 \mathrm{~cm}$ \\
\hline $\begin{array}{l}\text { Russell Key } \\
\text { Core } \\
\# 0206125\end{array}$ & $\begin{array}{l}25^{\circ} \\
03.871^{\prime}\end{array}$ & $80^{\circ} 37.501^{\prime}$ & $170 \mathrm{~cm}$ & $46 \mathrm{~cm}$ \\
\hline $\begin{array}{l}\text { Russell Key } \\
\text { Core } \\
\# 0206127\end{array}$ & $\begin{array}{l}25^{\circ} \\
03.851^{\prime}\end{array}$ & $80^{\circ} 37.371^{\prime}$ & $170 \mathrm{~cm}$ & $46 \mathrm{~cm}$ \\
\hline $\begin{array}{l}\text { Ninemile } \\
\text { Bank } \\
\text { Core } \\
\# 0208134\end{array}$ & $\begin{array}{l}24^{\circ} \\
57.128^{\prime}\end{array}$ & $80^{\circ} 53.607^{\prime}$ & $244 \mathrm{~cm}$ & $37 \mathrm{~cm}$ \\
\hline $\begin{array}{l}\text { Trout Cove } \\
\text { Core } \\
\# 02061211\end{array}$ & $\begin{array}{l}25^{\circ} \\
12.582^{\prime}\end{array}$ & $80^{\circ} 31.932^{\prime}$ & $96 \mathrm{~cm}$ & $47 \mathrm{~cm}$ \\
\hline
\end{tabular}


Table 2.2 Radiocarbon dates for Ninemile Bank obtained by L. Collins from Beta Analytic Laboratory, Miami, Florida. Ages were corrected for ${ }^{13} \mathrm{C} /{ }^{12} \mathrm{C}$, and global and local geographic reservoir effects (Talma and Vogel, 1993) prior to the calibration $\left({ }^{13} \mathrm{C} /{ }^{12} \mathrm{C}=1.6\right.$; local reservoir effect $=-5 \pm 20$; global reservoir effect $=-200$ to 500$)$. The database of Marine 98 (Stuiver et al., 1998) was used for calibration.

\begin{tabular}{|l|l|l|l|l|l|}
\hline $\begin{array}{l}\text { Core } \\
\text { location }\end{array}$ & $\begin{array}{l}\text { Core } \\
\text { depth } \\
(\mathrm{cm})\end{array}$ & $\begin{array}{l}\text { Type of } \\
\text { material }\end{array}$ & $\begin{array}{l}\text { Measured } \\
\text { radiocarbon } \\
\text { age (B.P.) }\end{array}$ & $\begin{array}{l}\text { Conventional } \\
\text { radiocarbon } \\
\text { age (B.P.) }\end{array}$ & $\begin{array}{l}\text { Two sigma age range } \\
\text { (Cal. Years B.P.) }\end{array}$ \\
\hline $\begin{array}{l}\text { Ninemile } \\
\text { Bank }\end{array}$ & $\begin{array}{l}120- \\
122\end{array}$ & Brachiodontes & $2340 \pm 40$ & $2750 \pm 40$ & $2660 \sim 2340$ \\
\hline 154 & $\begin{array}{l}178- \\
180\end{array}$ & $\begin{array}{l}\text { Three 0.5-cm } \\
\text { bivalves and 1 } \\
\text { Brachiodontes } \\
\text { fragment }\end{array}$ & $3030 \pm 40$ & $3400 \pm 40$ & $3360 \sim 3200$ \\
\hline $208-$ & $\begin{array}{l}\text { One 0.5-cm } \\
\text { broken } \\
\text { gastropod }\end{array}$ & $3210 \pm 40$ & $3590 \pm 40$ & $3580 \sim 3390$ \\
\hline $228-$ & $\begin{array}{l}\text { 2 gastropod } \\
\text { fragments, } 1 \\
\text { topshell and 1 } \\
\text { olive shell }\end{array}$ & $3320 \pm 40$ & $3720 \pm 40$ & $3800 \sim 3530$ \\
\hline
\end{tabular}


Table 2.3 Anthropogenic and environmental events affecting freshwater flow in South Florida over the last 120 years (Montague and Ley, 1993; Light and Dineen, 1994, Enfield et al., 2001).

\begin{tabular}{|c|c|}
\hline Years & Events \\
\hline $1905-1912$ & Construction of Flagler Railroad \\
\hline $1915-1928$ & $\begin{array}{l}\text { Construction of the trans-Everglades } \\
\text { Tamiami Trail roadway linking Miami } \\
\text { with Florida's west coast; high } \\
\text { precipitation during AMO cool phase; } \\
\text { frequent hurricanes with high rainfall }\end{array}$ \\
\hline 1954-1959 & $\begin{array}{l}\text { Construction of Everglades Agriculture } \\
\text { Area partitioning } 700,000 \text { acres of rich } \\
\text { muck lands to the north from the } \\
\text { remainder of the Everglades to the south, } \\
\text { through a series of levees and water- } \\
\text { diversion canals; low rainfall during } \\
\text { AMO warm phase; droughts during the } \\
\text { middle } 1950 \text { s }\end{array}$ \\
\hline $1960-1963$ & $\begin{array}{l}\text { Construction of Water Retention Areas in } \\
\text { the Everglades }\end{array}$ \\
\hline $1965-1970$ & $\begin{array}{l}\text { A series of short-term water management } \\
\text { plans for freshwater flow by south } \\
\text { Florida Water Management District }\end{array}$ \\
\hline 1970-early 1980s & $\begin{array}{l}\text { Congressionally mandated Monthly } \\
\text { Allocation Plan of water delivery to } \\
\text { Taylor Slough, a major freshwater input } \\
\text { to Florida Bay }\end{array}$ \\
\hline Post-early 1980s & $\begin{array}{l}\text { Water delivery to Shark River Slough and } \\
\text { Taylor Slough under the Rainfall Plan of } \\
\text { the South Florida Water Management } \\
\text { District; }\end{array}$ \\
\hline $1987-1994$ & Seagrass dieoff \\
\hline
\end{tabular}


Table 2.4 Time intervals defined by land-use activities and the recent seagrass dieoff. These intervals are used in the ANOVAs.

\begin{tabular}{|l|l|l|}
\hline Interval Number & Event & Time \\
\hline Interval 1 & Pre-agriculture & $1880-1905$ \\
\hline Interval 2 & $\begin{array}{l}\text { Agricultural buildup, and } \\
\text { Flagler Railroad, Tamiami } \\
\text { Trail and canal } \\
\text { construction }\end{array}$ & $1906-1930$ \\
\hline Interval 3 & $\begin{array}{l}\text { Agriculture without } \\
\text { additional construction of } \\
\text { canals }\end{array}$ & $1931-1950$ \\
\hline Interval 4 & $\begin{array}{l}\text { Agriculture intensification } \\
\text { with construction of more } \\
\text { canals, Water Retention } \\
\text { Areas, and a series of water } \\
\text { management plans }\end{array}$ & $1951-1986$ \\
\hline Interval 5 & $\begin{array}{l}\text { Seagrass dieoff } \\
\text { Seagrass recovery }\end{array}$ & $1987-1994$ \\
\hline
\end{tabular}


Table 2.5 Sedimentation accumulation rates and maximum extent downcore of ${ }^{210} \mathrm{~Pb}$ ages for the six studied cores.

\begin{tabular}{|c|c|c|c|c|c|c|}
\hline Site & Bob Alleı & Bank & Russell $\mathrm{F}$ & & Ninemile & Trout \\
\hline Core \# & 0206122 & 0206124 & 0206125 & 0206127 & 0208134 & 02061211 \\
\hline $\begin{array}{l}\text { Sediment } \\
\text { accu. rate } \\
\text { (cm/year) }\end{array}$ & 0.68 & 0.36 & 1.18 & 1.82 & 0.82 & 0.38 \\
\hline $\begin{array}{l}\text { Maximum } \\
\text { depth and year } \\
\text { for excess } \\
{ }^{210} \mathrm{~Pb} \text { activity } \\
(\mathrm{dpm} / \mathrm{g})\end{array}$ & $\begin{array}{l}52 \mathrm{~cm}, \\
1927\end{array}$ & $\begin{array}{l}30 \mathrm{~cm}, \\
1910\end{array}$ & $\begin{array}{l}122 \mathrm{~cm}, \\
1899\end{array}$ & $\begin{array}{l}138 \mathrm{~cm} \\
1925\end{array}$ & $\begin{array}{l}62 \mathrm{~cm}, \\
1922\end{array}$ & $\begin{array}{l}36 \mathrm{~cm} \\
1906\end{array}$ \\
\hline $\begin{array}{l}\text { Maximum } \\
\text { depth and } \\
\text { ages } \\
\text { examined }\end{array}$ & $\begin{array}{l}78 \mathrm{~cm}, \\
1889\end{array}$ & $\begin{array}{l}40 \mathrm{~cm}, \\
1882\end{array}$ & $\begin{array}{l}140 \mathrm{~cm}, \\
1884\end{array}$ & $\begin{array}{l}148 \mathrm{~cm}, \\
1919\end{array}$ & $\begin{array}{l}92 \mathrm{~cm}, \\
1882\end{array}$ & $\begin{array}{l}46 \mathrm{~cm}, \\
1880\end{array}$ \\
\hline
\end{tabular}


Table 2.6 General ecology of predominantly seagrass-associated benthic foraminifera, and references to the literature.

\begin{tabular}{|c|c|c|}
\hline Species & Ecology & Ref. \\
\hline $\begin{array}{l}\text { Archaias compressus } \\
\text { (d'Orbigny ) }\end{array}$ & $\begin{array}{l}\text { Fairly high frequencies; absent from the } \\
\text { more restricted parts of the bay and from } \\
\text { deep water; common on seagrass }\end{array}$ & 2,5 \\
\hline $\begin{array}{l}\text { Articulina mucronata } \\
\text { (d'Orbigny) }\end{array}$ & $\begin{array}{l}\text { High frequency in the area of shallow } \\
\text { mud flats located towards the center of } \\
\text { Florida Bay; abundant on seagrass } \\
\text { through the entire year }\end{array}$ & 2,4 \\
\hline $\begin{array}{l}\text { Cyclogyra involvens } \\
\text { (Reuss) }\end{array}$ & Low frequency, abundant on seagrass & 2 \\
\hline $\begin{array}{l}\text { Discorbis mira Cushman, } \\
\text { D. rosea (d'Orbigny ) }\end{array}$ & $\begin{array}{l}\text { Medium frequency, most common in the } \\
\text { shallow waters adjacent to the lower } \\
\text { Florida Keys; found to be living on } \\
\text { Thalassia in small populations }\end{array}$ & $2,4,5$ \\
\hline $\begin{array}{l}\text { Miliolinella fichtelliana } \\
\text { (d'Orbigny) } \\
\text { M. circularis Bornemann }\end{array}$ & $\begin{array}{l}\text { Random distribution with low to medium } \\
\text { frequency; abundant on seagrass through } \\
\text { entire year }\end{array}$ & $2,4,7$ \\
\hline M. labiosa (d'Orbigny) & $\begin{array}{l}\text { Not found in deep water; random } \\
\text { distribution with low to medium } \\
\text { frequency; more important on weed than } \\
\text { in the sediments; found on seagrass } \\
\text { blades; abundant on seagrass through } \\
\text { entire year }\end{array}$ & $4,5,6$ \\
\hline Pyrgo denticulate Brady & $\begin{array}{l}\text { Low frequency; limited to waters adjacent } \\
\text { to the lower keys; common on seagrass }\end{array}$ & $2,4,5$ \\
\hline $\begin{array}{l}\text { Quinqueloculina } \\
\text { agglutinans (d'Orbigny) }\end{array}$ & $\begin{array}{l}\text { Frequent in Florida Bay; highest } \\
\text { frequencies with coarsest sediment } \\
\text { suggesting sorting by wave action; } \\
\text { disappears in brackish environments and } \\
\text { deeper water }\end{array}$ & 2,4 \\
\hline Q. polygona d'Orbigny & $\begin{array}{l}\text { Limited to carbonate platform and shoal } \\
\text { areas associated with high diversity, } \\
\text { miliolid-dominated environments; } \\
\text { medium frequencies in Florida Bay, } \\
\text { species appears to be mainly restricted to } \\
\text { the shallow waters of Florida Bay }\end{array}$ & 4 \\
\hline $\begin{array}{l}\text { Spirillina vivipara } \\
\text { Ehrenberg }\end{array}$ & Low frequency; common on seagrass & 2 \\
\hline $\begin{array}{l}\text { Triloculina carinata } \\
\text { d'Orbigny }\end{array}$ & $\begin{array}{l}\text { Common on seagrass; rare to common } \\
\text { occurrences }\end{array}$ & 4 \\
\hline
\end{tabular}




\begin{tabular}{|c|c|c|}
\hline T. linneiana d'Orbigny & $\begin{array}{l}\text { Restricted to carbonate platform and shoal } \\
\text { areas associated with high-diversity, } \\
\text { miliolid-dominant assemblages }\end{array}$ & 2 \\
\hline $\begin{array}{l}\text { Rosalina candeiana } \\
\text { d'Orbigny }\end{array}$ & $\begin{array}{l}\text { Prefers living on seagrass; smaller in size; } \\
\text { accumulates on many of the blades; rare } \\
\text { or absent on the blades when near tidal } \\
\text { channels }\end{array}$ & 6 \\
\hline $\begin{array}{l}\text { Cornuspiramia antillarum } \\
\text { (Cushman) } \\
\text { Nubecularia lucifuga } \\
\text { Defrance, } \\
\text { Hemidiscella palabunda } \\
\text { Bock, } \\
\text { Planorbulina acervalis } \\
\text { Brady }\end{array}$ & $\begin{array}{l}\text { Most common on seagrass blades; } \\
\text { attached to seagrass blades; lives on } \\
\text { seagrass and completes production while } \\
\text { still attached }\end{array}$ & 1,6 \\
\hline $\begin{array}{l}\text { Triloculina eburnea } \\
\text { d'Orbigny, } \\
\text { Valvulina oviedoiana } \\
\text { d'Orbigny, } \\
\text { Triloculina rotunda } \\
\text { d'Orbigny, } \\
\text { Rosalina floridana } \\
\text { (Cushman) }\end{array}$ & $\begin{array}{l}\text { Primary weed fauna; more important on } \\
\text { seagrass than in the sediments }\end{array}$ & 7 \\
\hline $\begin{array}{l}\text { Sorites marginalis } \\
\text { (Lamarck) }\end{array}$ & $\begin{array}{l}\text { Commonly adheres flush to the blades of } \\
\text { seagrass }\end{array}$ & 5 \\
\hline \multicolumn{2}{|c|}{$\begin{array}{l}\text { References: } \\
\text { 1. Bock, } 1969 \\
\text { 2. Bock et al., } 1971 \\
\text { 3. Brasier, } 1975 \\
\text { 4. Fujita and Hallock, } 1999 \\
\text { 5. Martin and Wright, } 1988 \\
\text { 6. Richardson, } 2000 \\
\text { 7. Steinker and Steinker, } 1976 \\
\text { 8. Wantland, } 1967\end{array}$} & \\
\hline
\end{tabular}




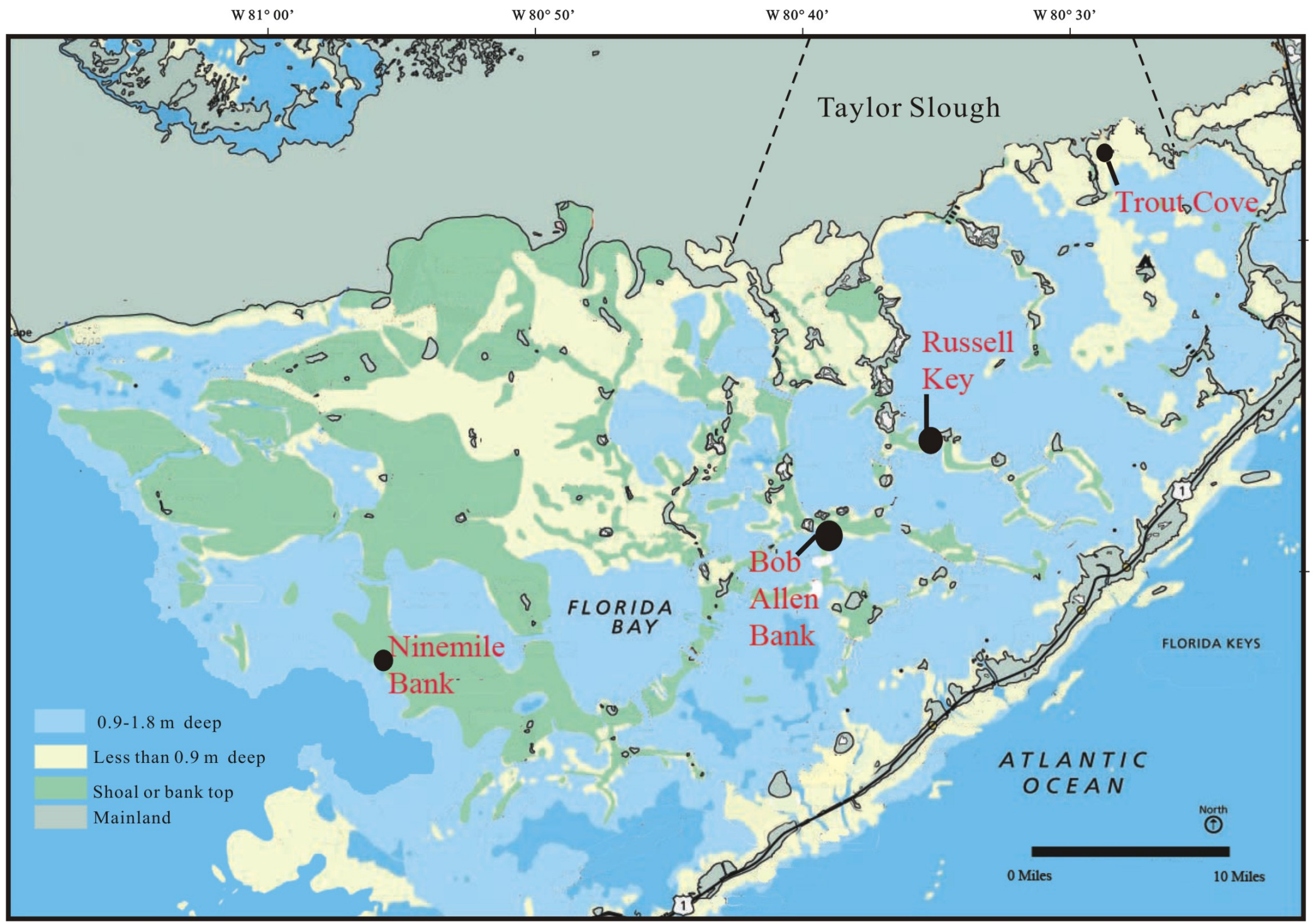

Figure 2.1 Map of Florida Bay showing four coring sites: Ninemile Bank, Bob Allen Bank, Russell Key and Trout Cove. 


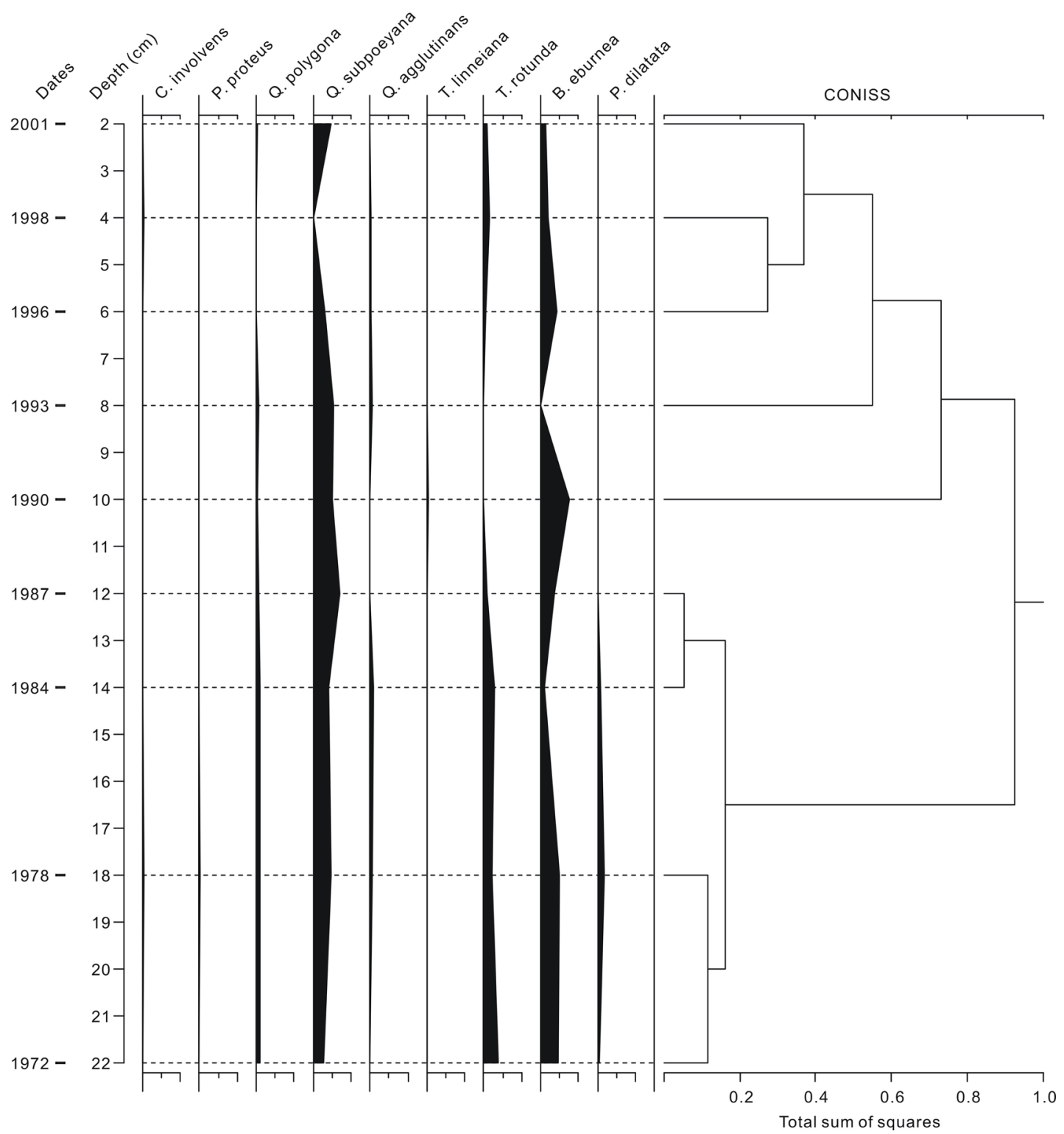

Figure 2.2 Percentages of seagrass-associated benthic foraminifera in Bob Allen Bank Core \#0206122, after $\sim 1970$, and CONISS clustering. 


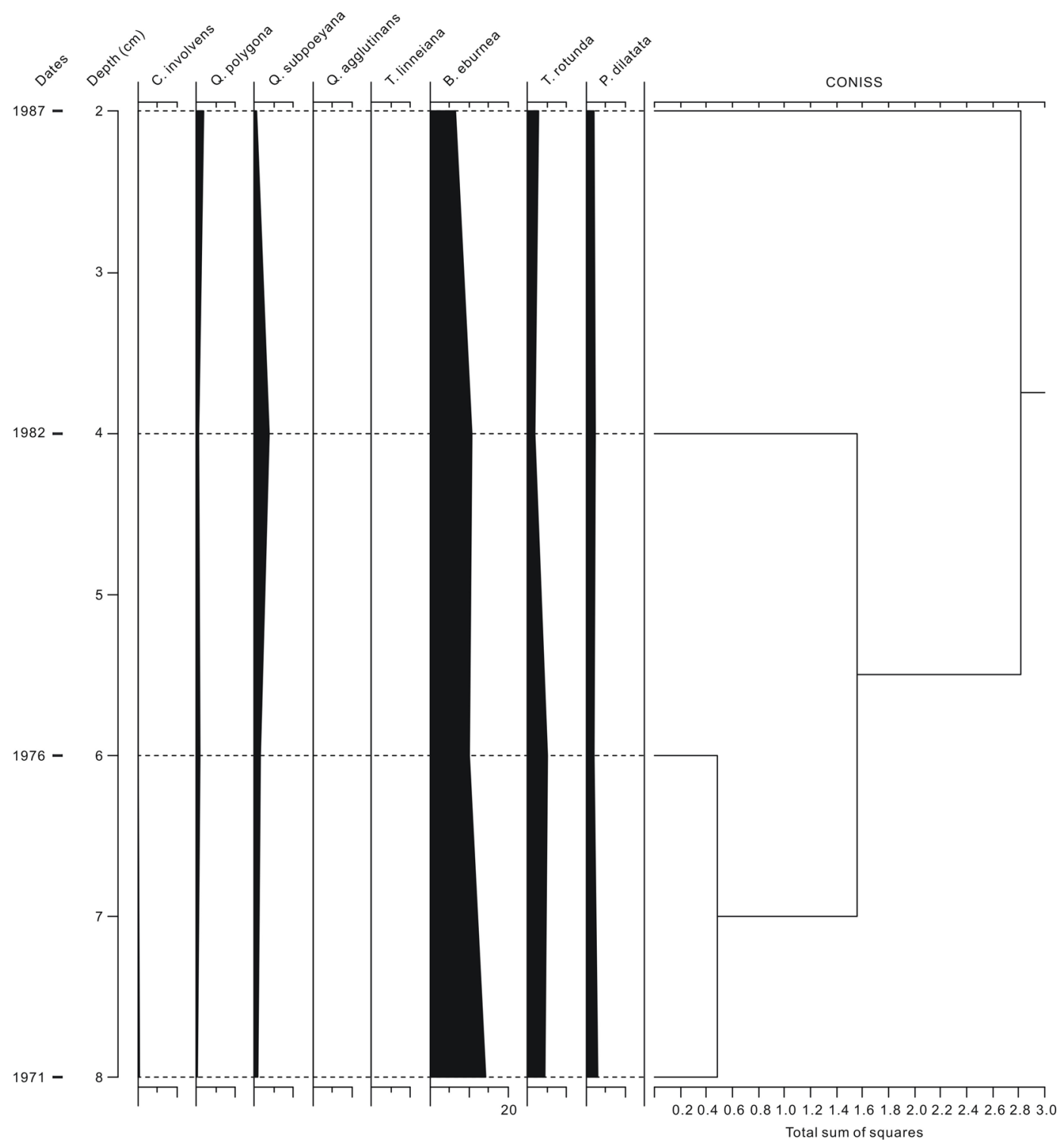

Figure 2.3 Percentages of seagrass-associated benthic foraminifera in Bob Allen Bank Core \#0206124, after 1970, and CONISS clustering. 


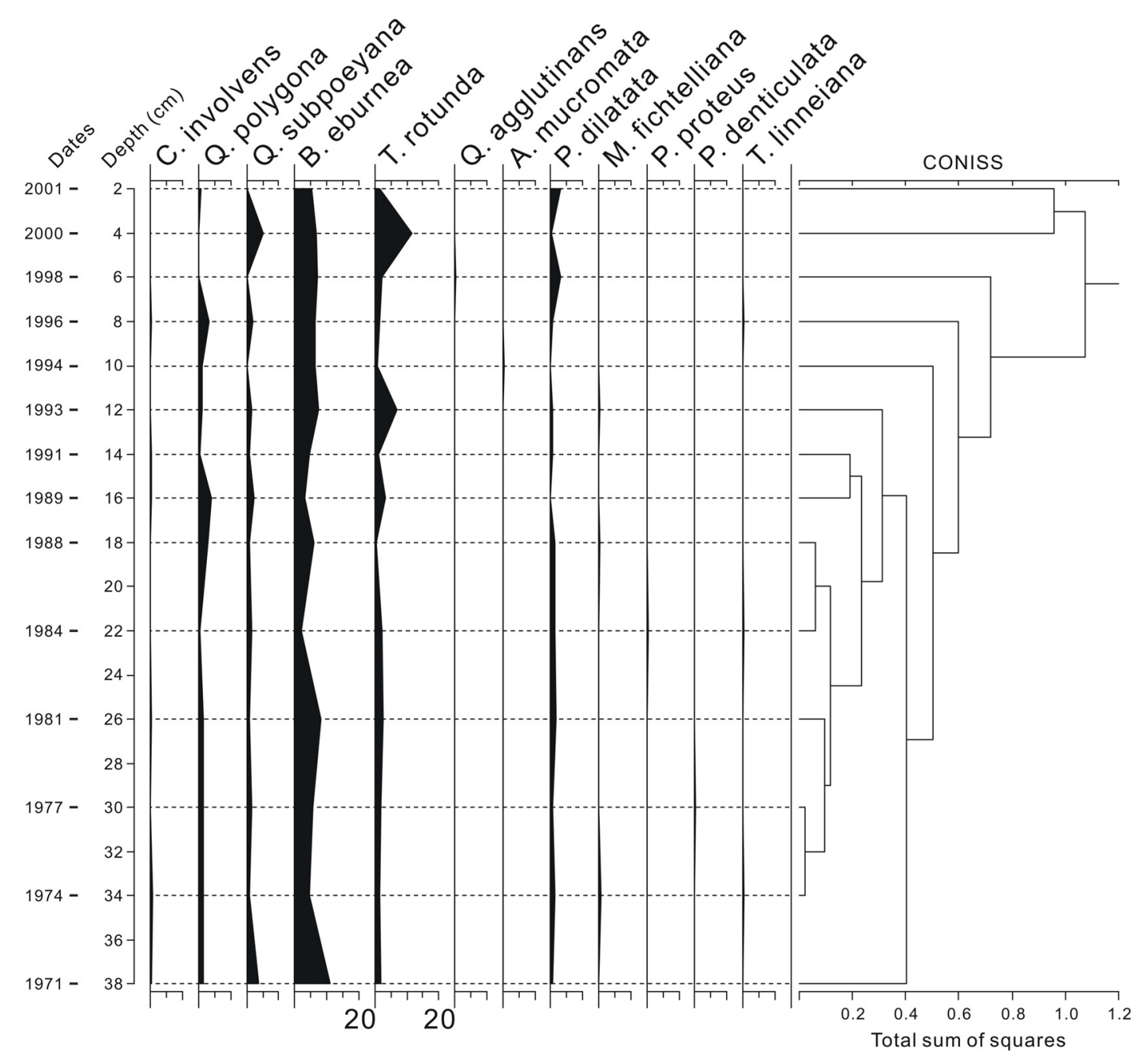

Figure 2.4 Percentages of seagrass-associated benthic foraminifera in Russell Key Core \#0206125, after 1970, and CONISS clustering. 


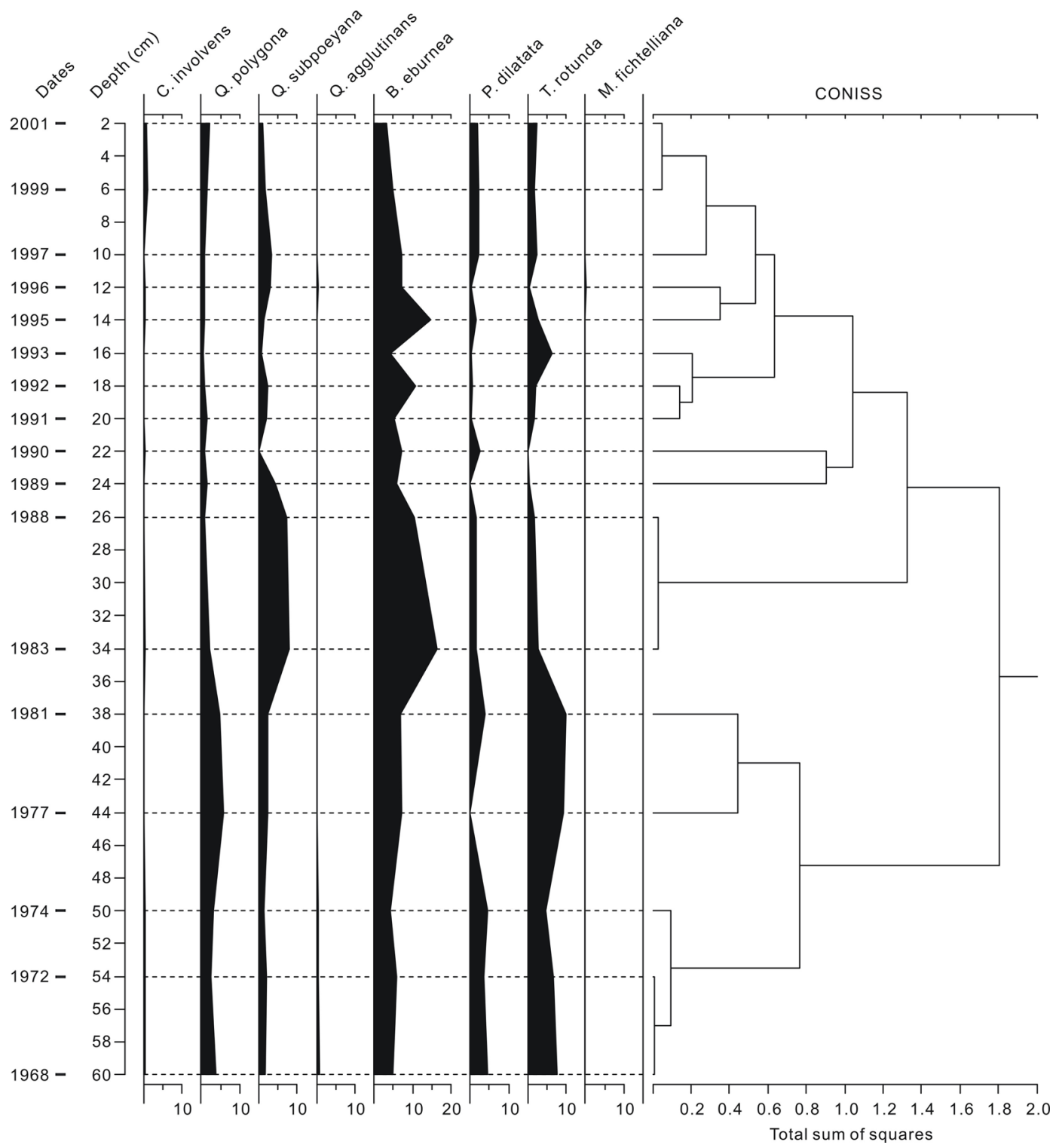

Figure 2.5 Percentages of seagrass-associated benthic foraminifera in Russell Key Core \#0206127, after 1970, and CONISS clustering. 


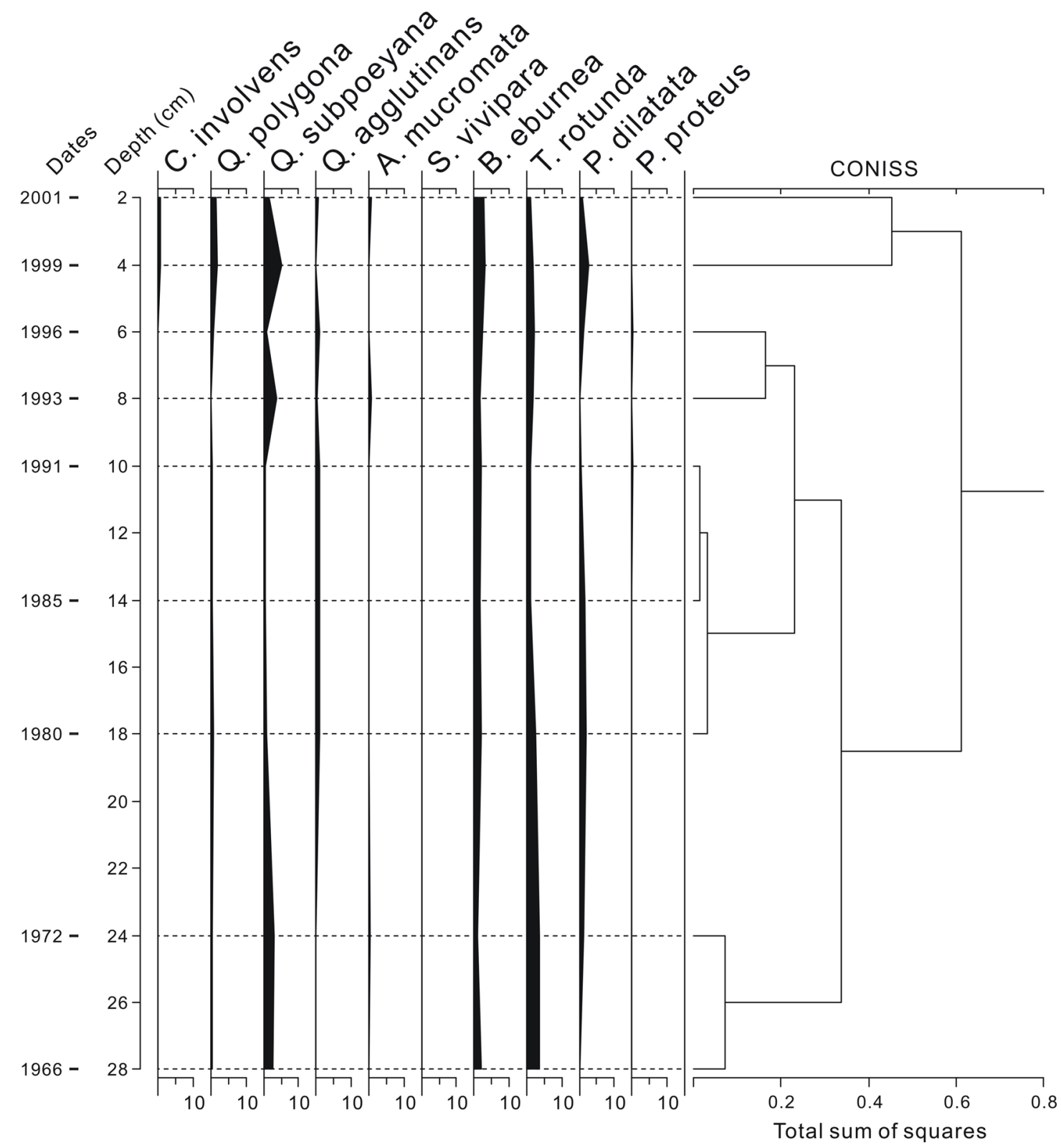

Figure 2.6 Percentages of seagrass-associated benthic foraminifera in Ninemile Bank Core \#0208134, after 1970 , and CONISS clustering. 


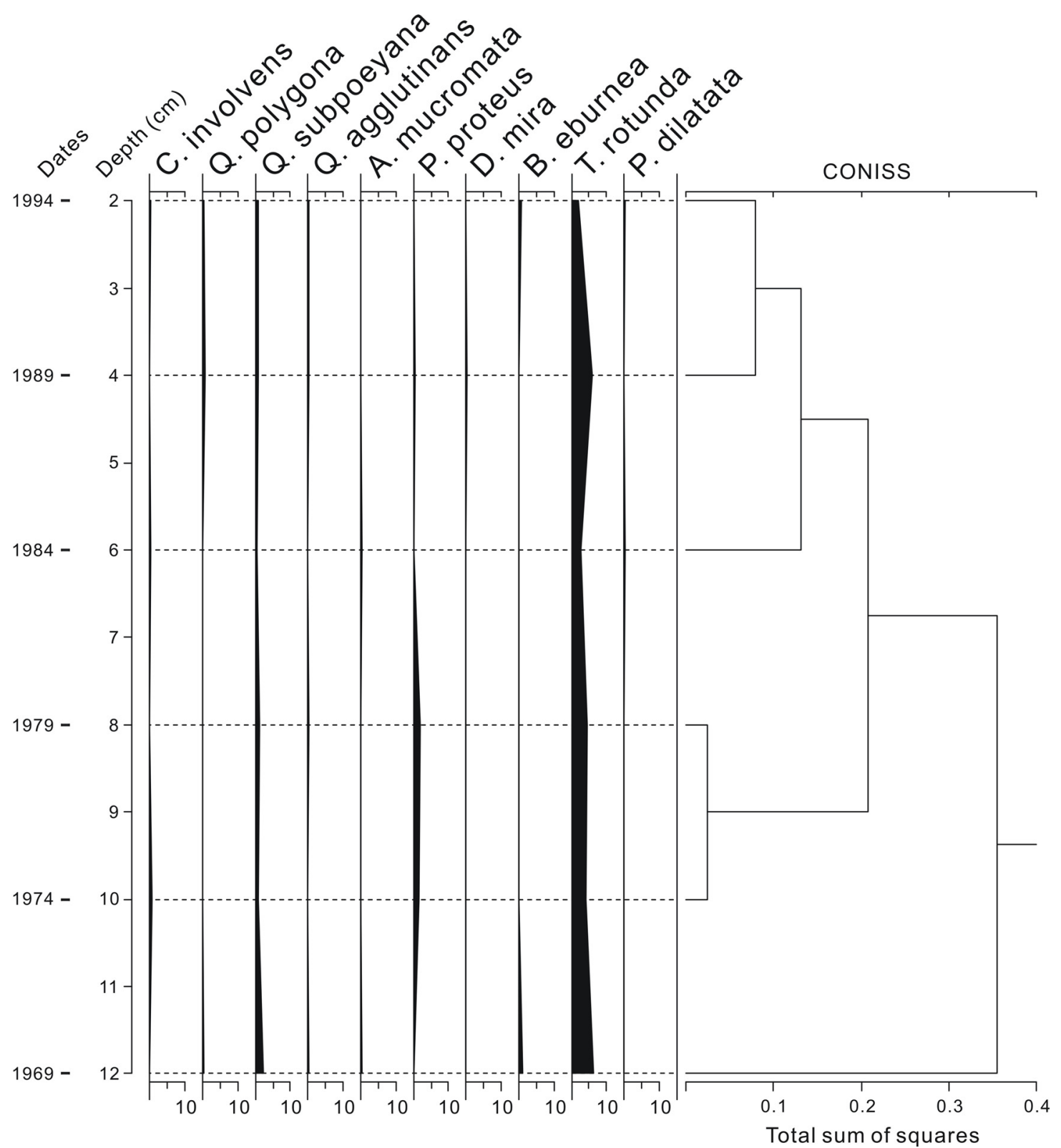

Figure 2.7 Percentages of seagrass-associated benthic foraminifera in Trout Cove Core \#02061211, after 1970, and CONISS clustering. 


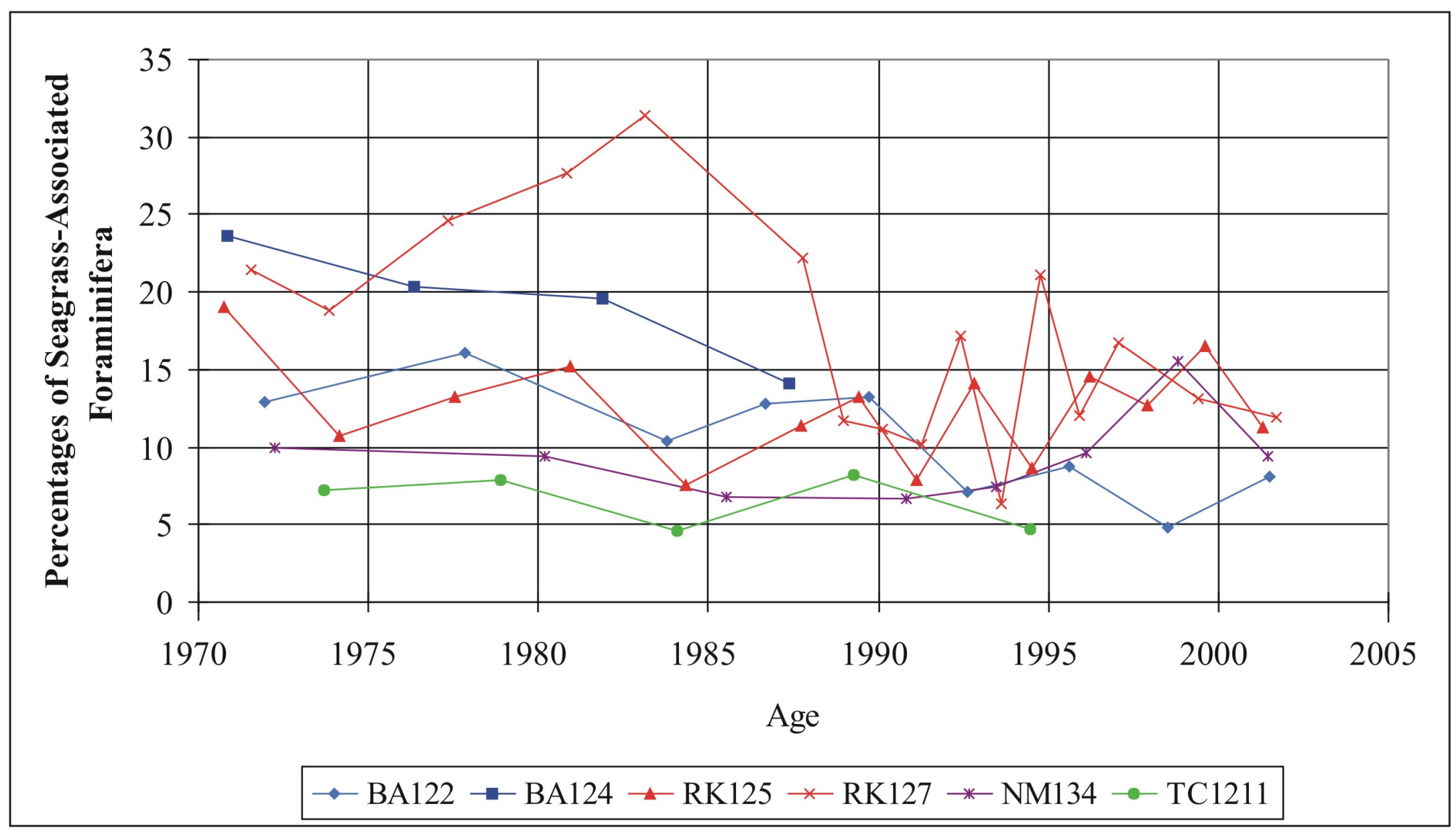

Figure 2.8 Trends in percentages of seagrass-associated benthic foraminifera between 1970 and 2001, all examined cores. BA122 = Bob Allen Core \#0206122, BA124 = Bob Allen Bank Core \#0206124, RK125 = Russell Key Core \#0206125, RK127 = Russell Key Core \#0206127, NM134 = Ninemile Bank Core \#0208134, TC1211 = Trout Cove Core \#02061211. 


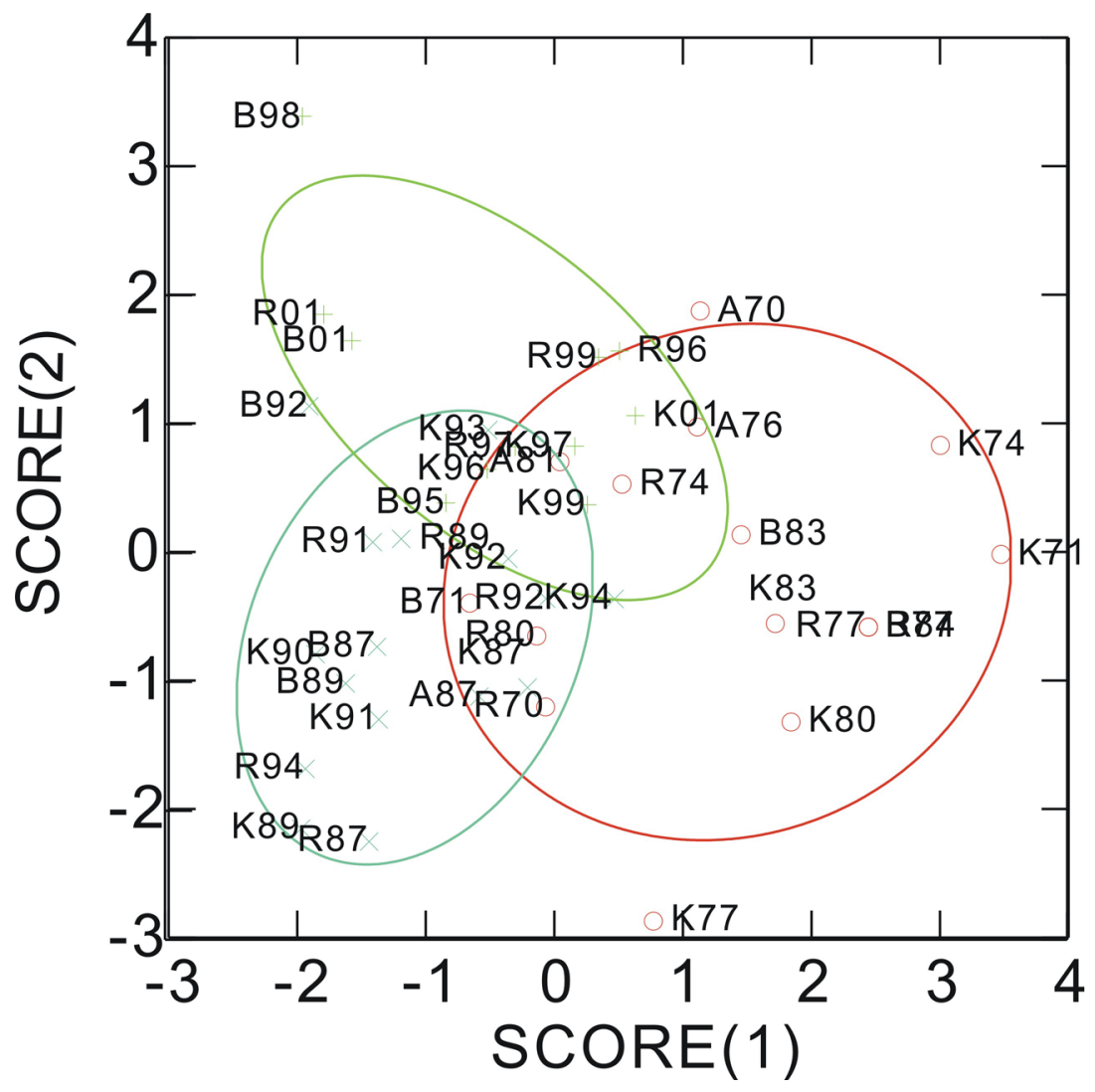

1: $1970-1986$

× 2:1987-1994

$+\quad 3: 1995-2001$

Figure 2.9 Discriminant analysis showing three separate intervals (all samples in this figure are from the Bob Allen Bank cores and Russell Key cores, central Florida Bay. 


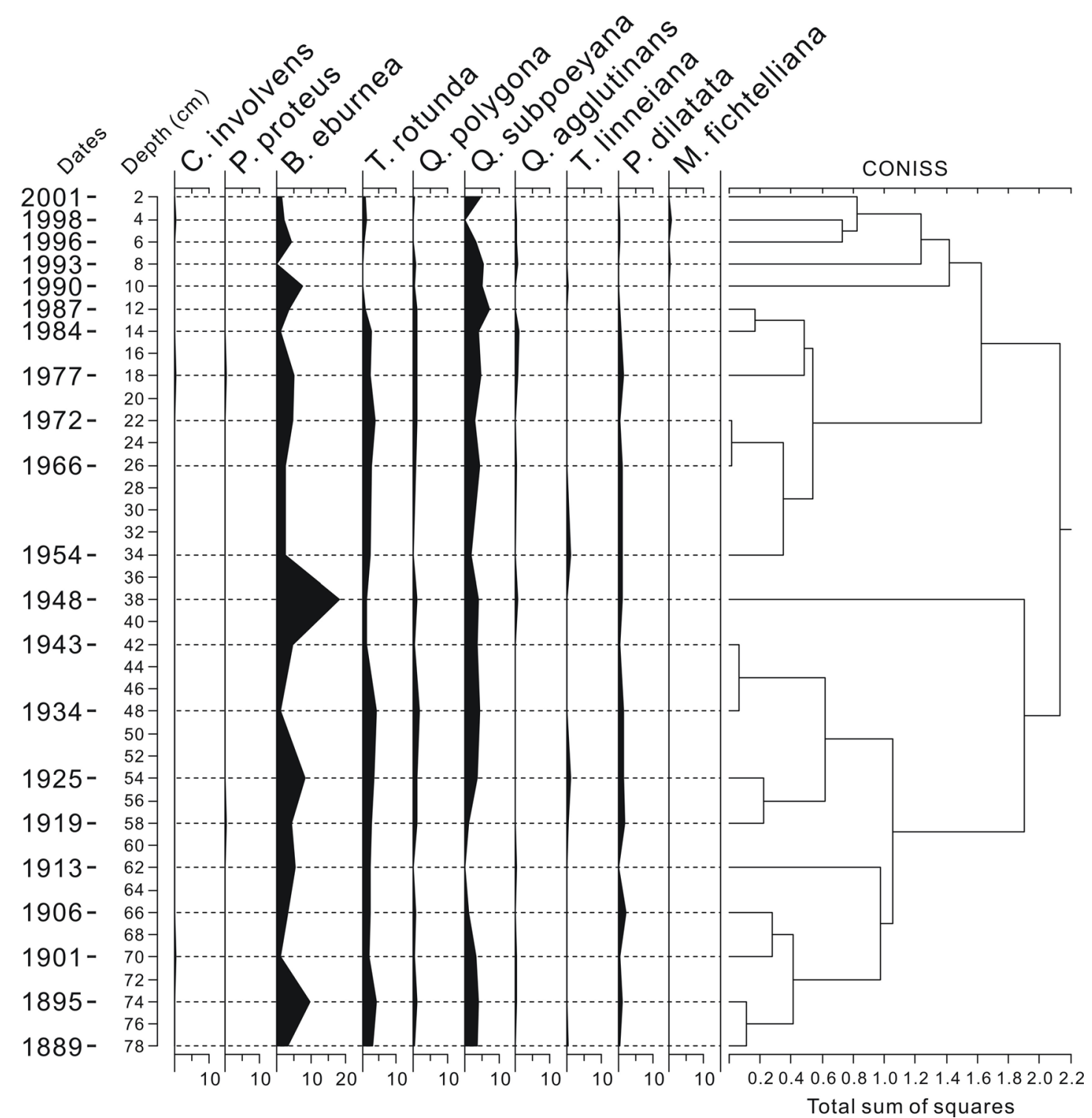

Figure 2.10 Percentages of seagrass-associated foraminifera in Bob Allen Bank Core \#0206122, 1880-2001, and CONISS clustering. 


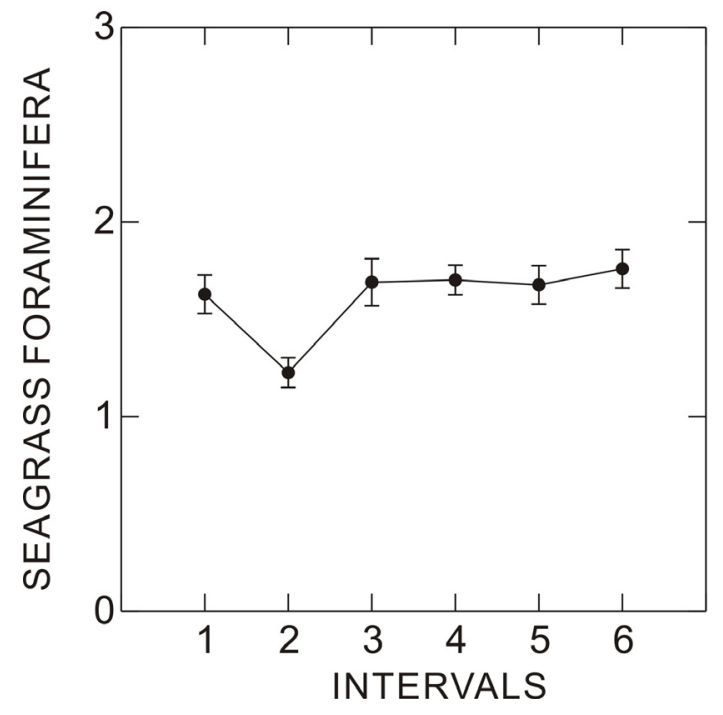

Figure 2.11 ANOVA of Bob Allen Bank Core \#0206122, last 120 years. Intervals 1-6 are defined in Table 2.4. 


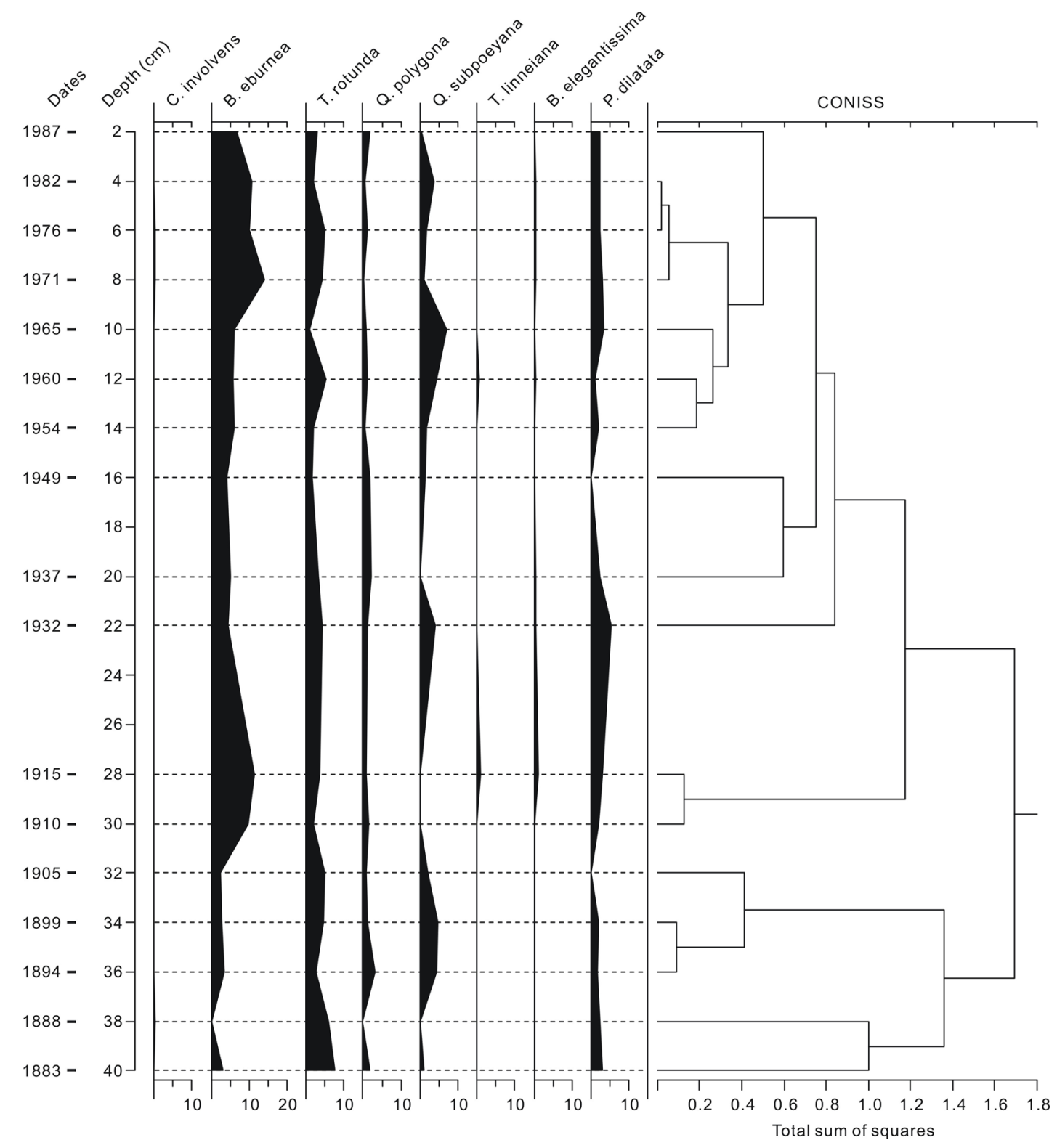

Figure 2.12 Percentages of seagrass-associated foraminifera in Bob Allen Bank Core \#0206124, 1880-2001, and CONISS clustering. 


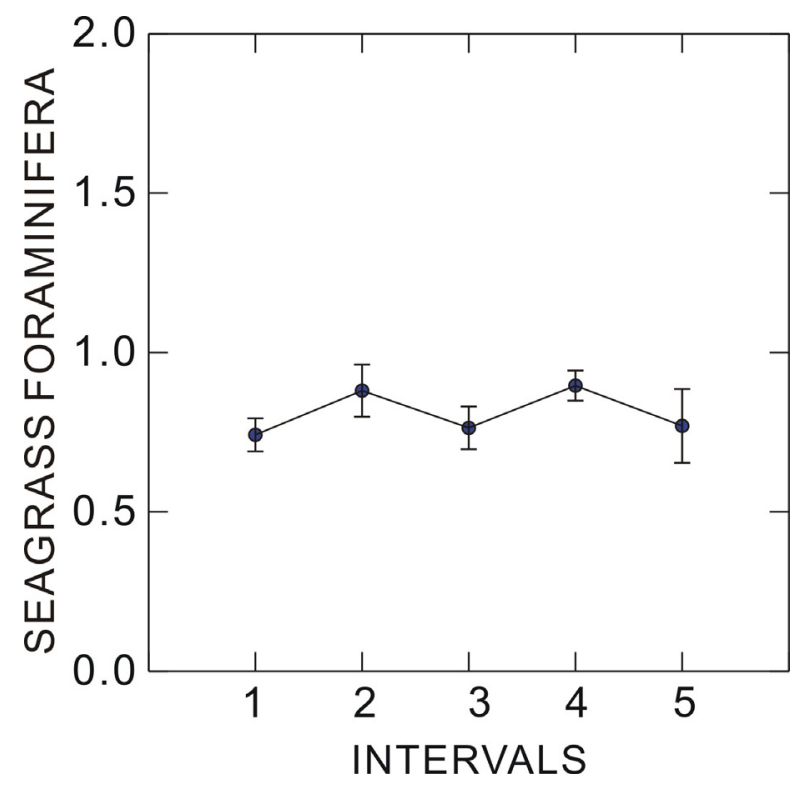

Figure 2.13 ANOVA of Bob Allen Bank Core \#0206124, last 120 years. Intervals 1-5 are defined in the text and in Table 2.4. 


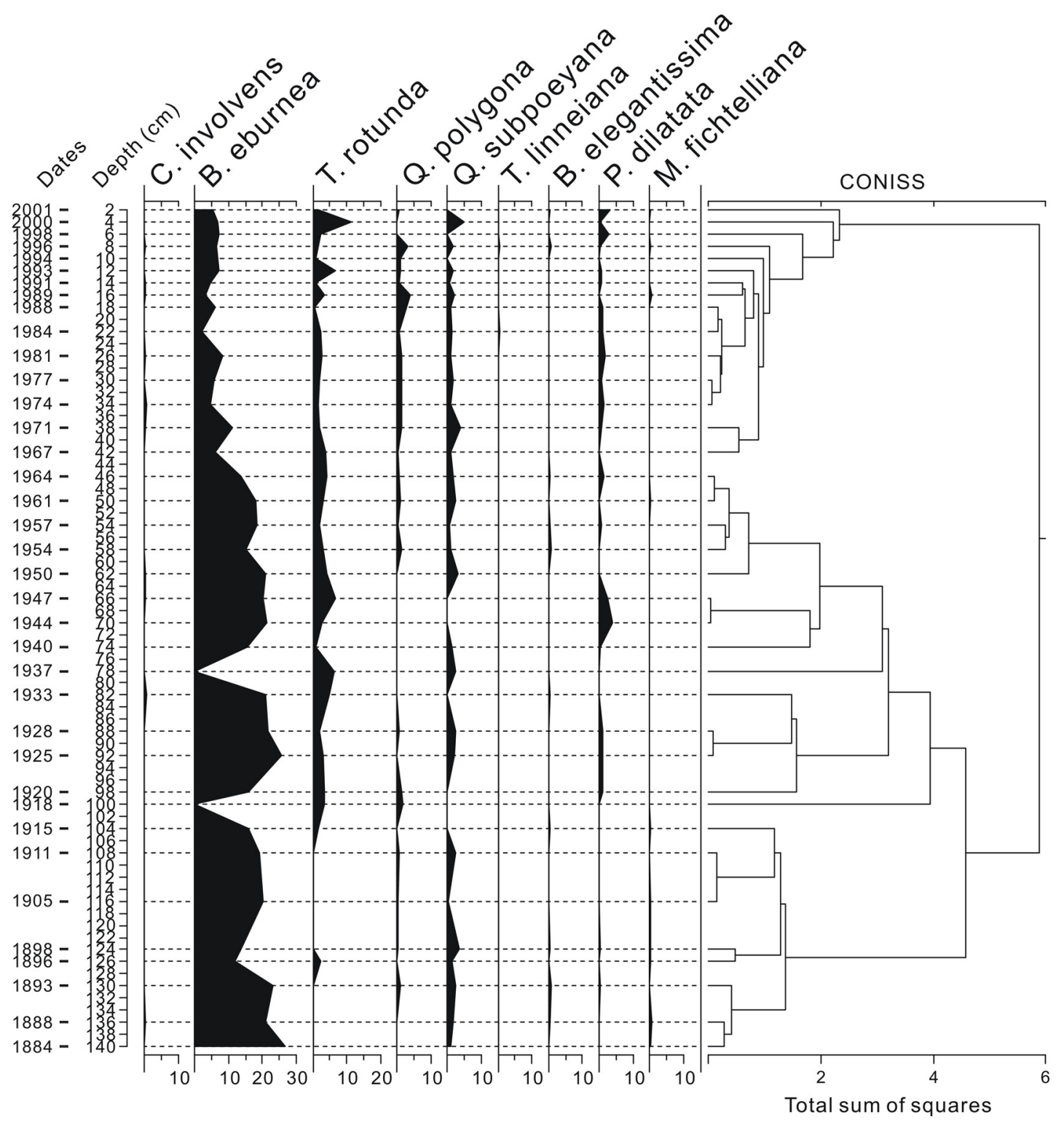

Figure 2.14 Percentages of seagrass-associated foraminifera in Russell Key Core \#0206125, 1880-2001, and CONISS clustering. 


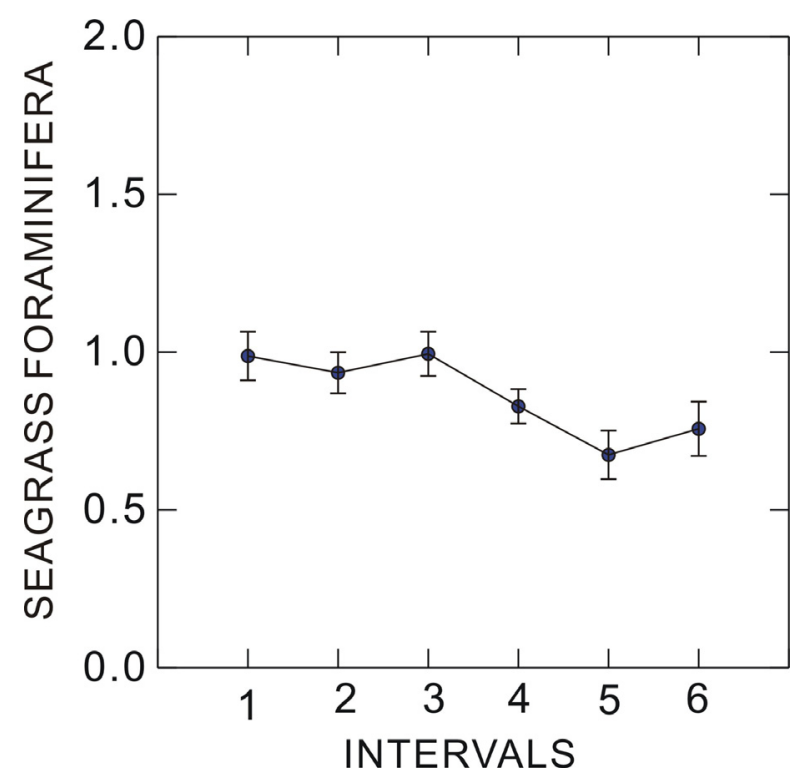

Figure 2.15 ANOVA of Russell Key Core \#0206125, last 120 years. Intervals 1-6 are defined in Table 2.4. 


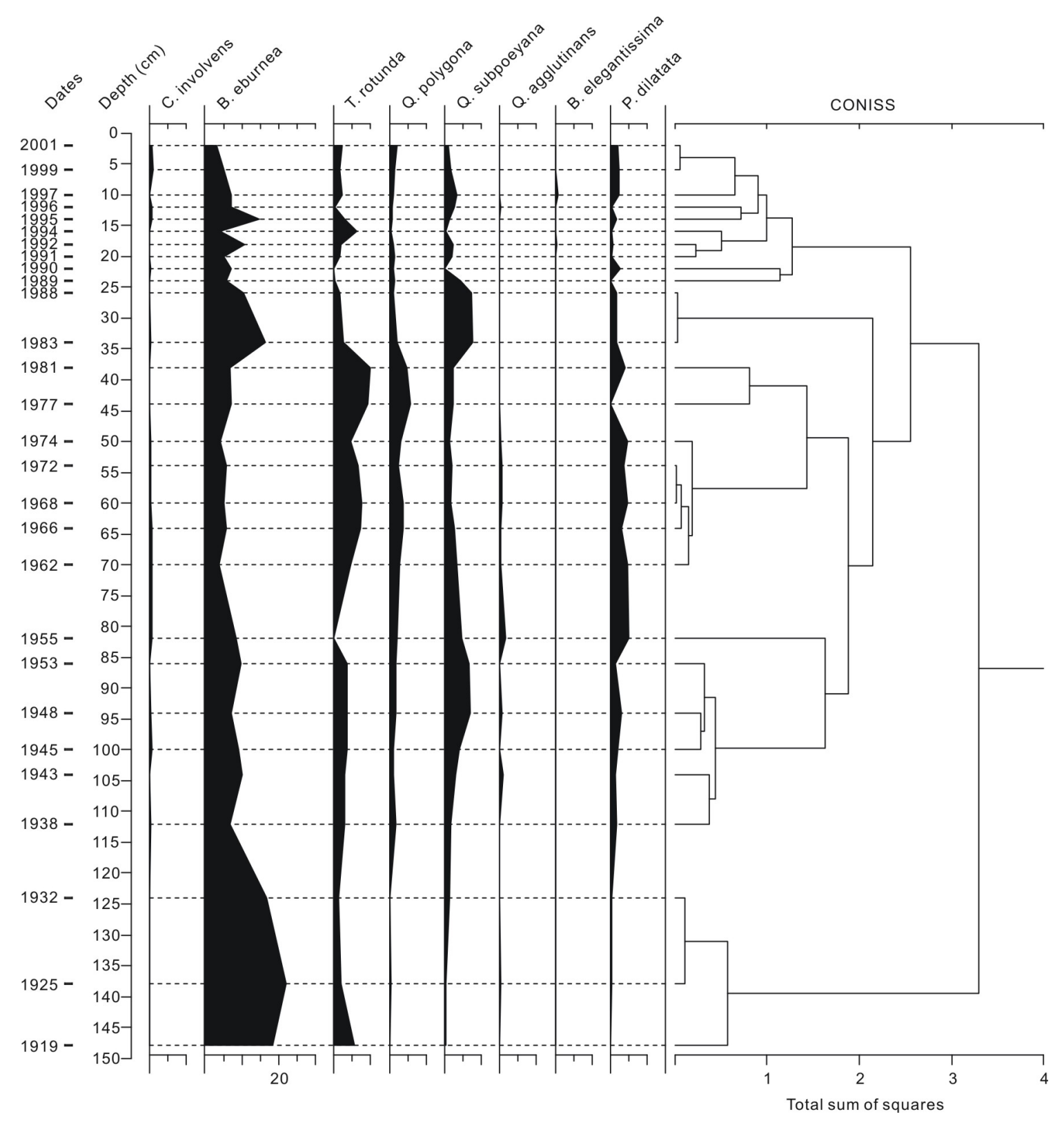

Figure 2.16 Percentages of seagrass-associated foraminifera in Russell Key Core \#0206127, 1938-2001, and CONISS clustering. 


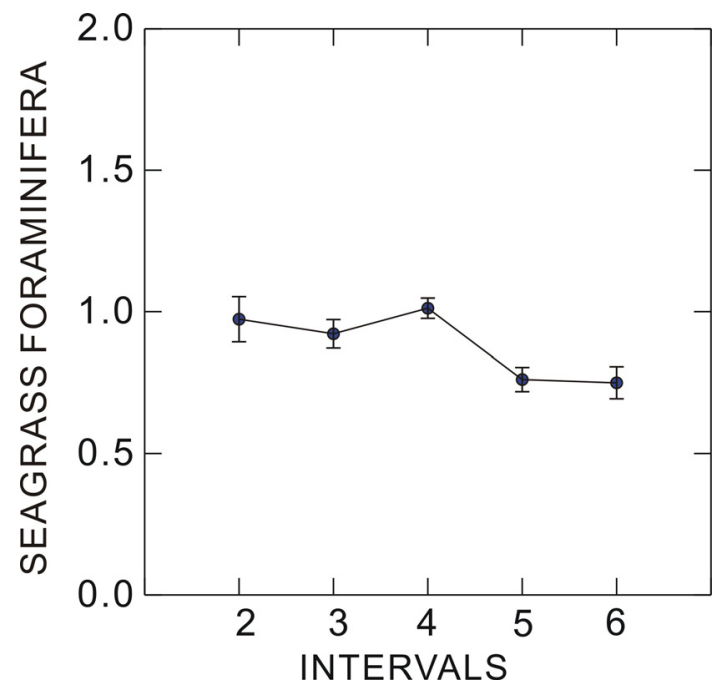

Figure 2.17 ANOVA of Russell Key Core \#0205127, last 120 years. Intervals 1-6 are defined in Table 2.4. 


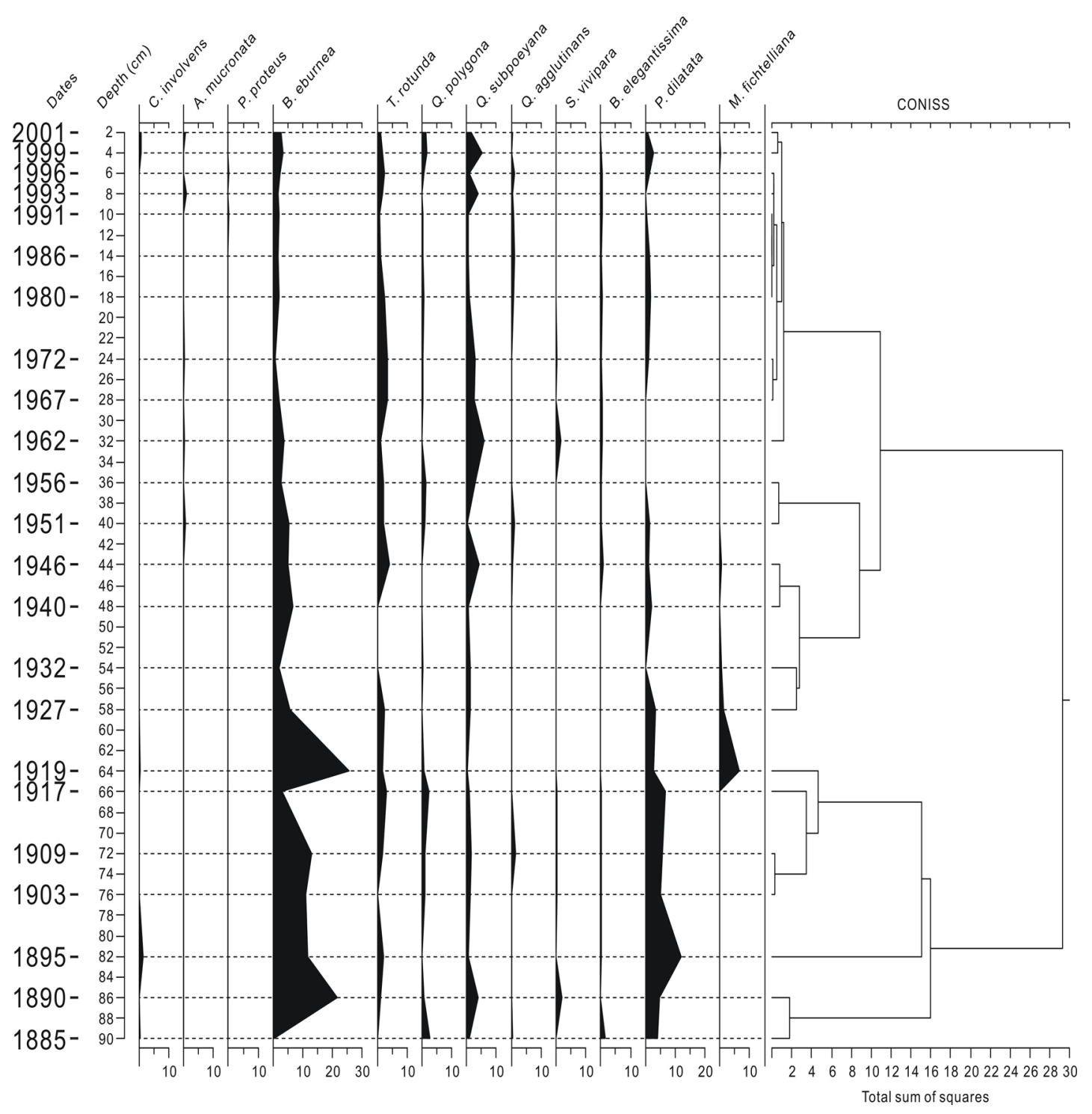

Figure 2.18 Percentages of seagrass-associated foraminifera in Ninemile Bank Core \#0208134, 1880-2001, and CONISS clustering. 


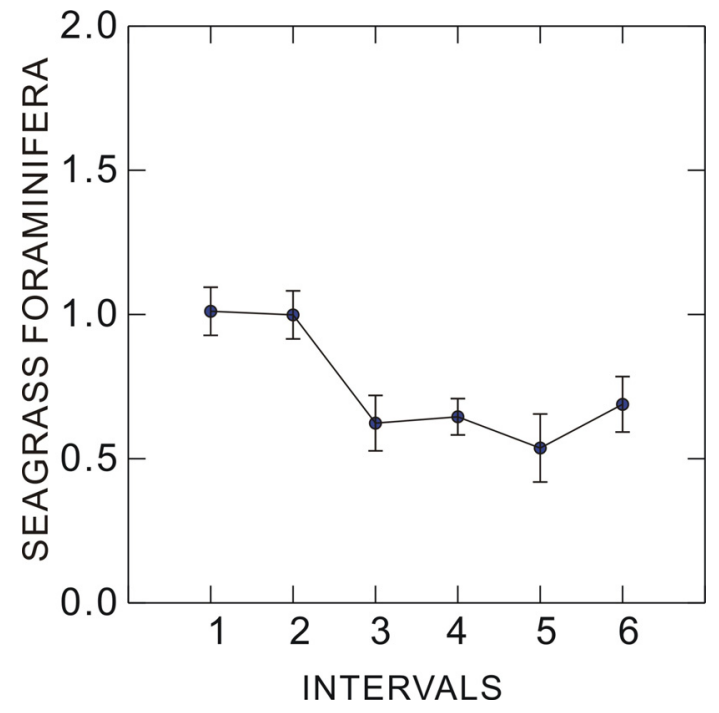

Figure 2.19 ANOVA of Ninemile Bank Core \#0208134, last 120 years. Intervals 1-6 are defined in Table 2.4. 


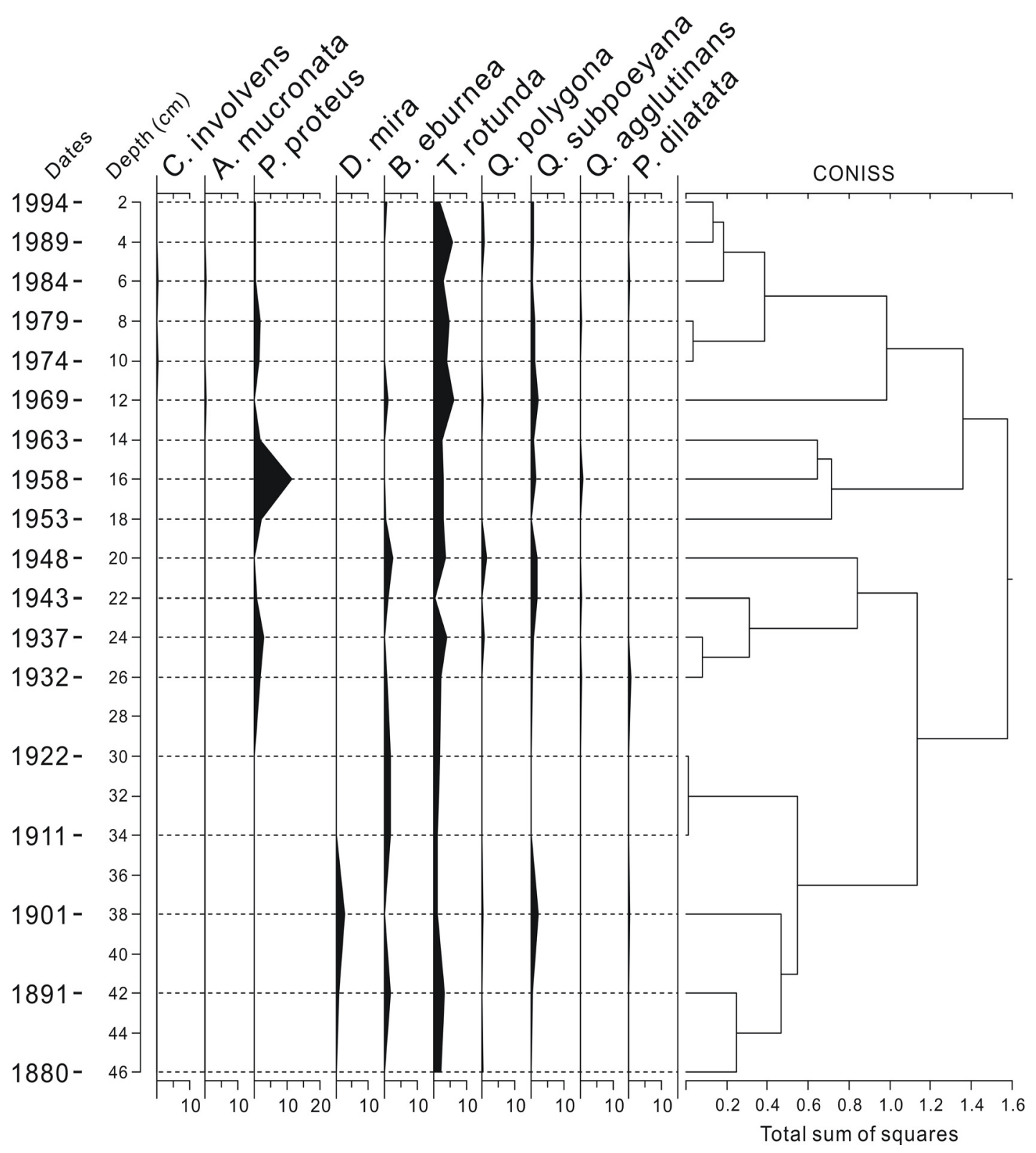

Figure 2.20 Percentages of seagrass-associated foraminifera in Trout Cove Core \#02061211, 1880-1994, and CONISS clustering. 


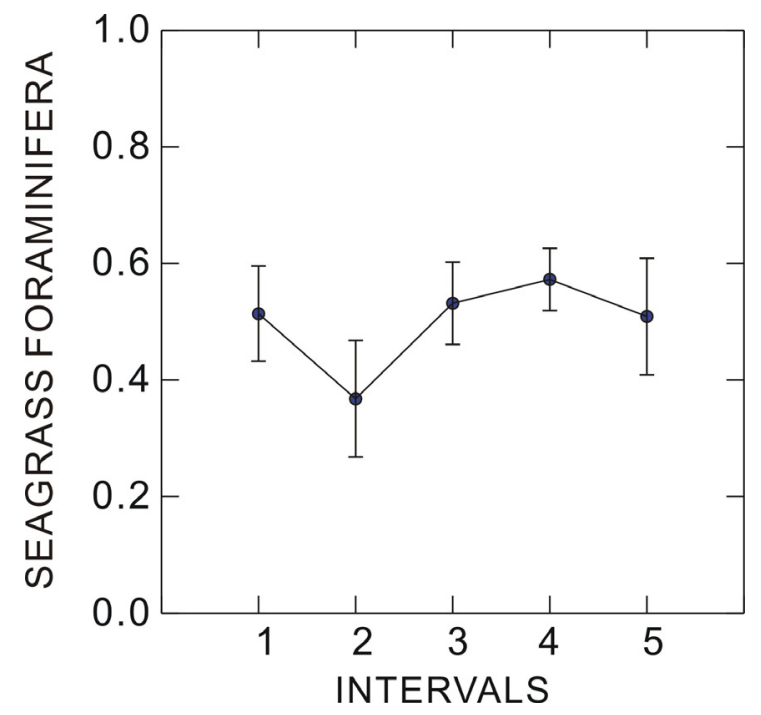

Figure 2.21 ANOVA of Trout Cove Core \#02061211, last 120 years. Intervals 1-5 are defined in Table 2.4 . 


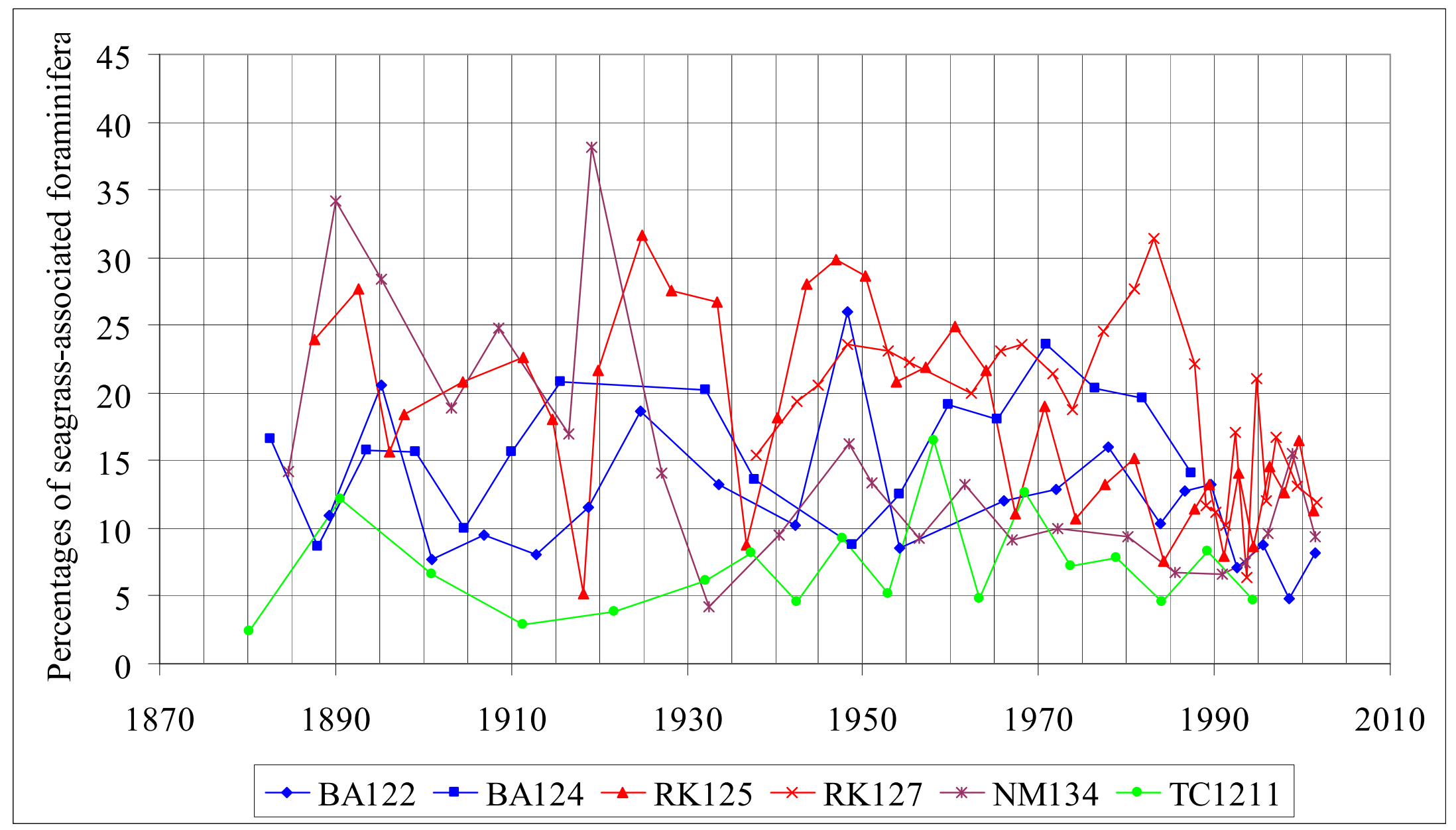

Figure 2.22 Total percentages of seagrass-associated foraminifera in all cores for 1880-2001. Symbols as in Figure 2.8. 


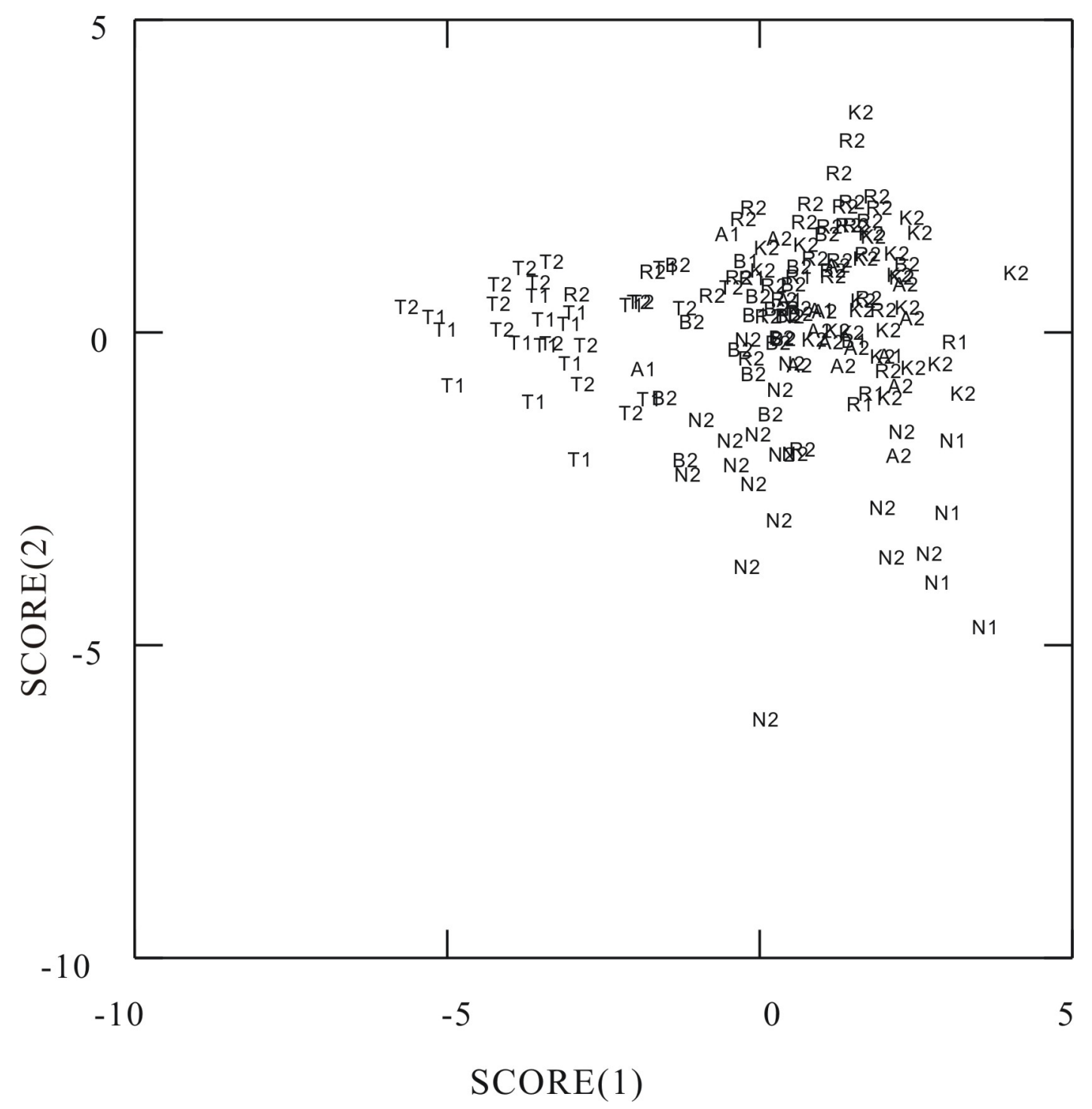

Figure 2.23 Discriminant analysis on all cores for the two time intervals. Symbols for the interval 1880-1905: B1=Bob Allen Core \#0206122, A1=Bob Allen Core \#0206124; R1=Russell Key Core \#0206125, K1=Russell Key Core \#0206127, N1=Ninemile Bank Core \#0208134, T1=Trout Cove Core \#02061211. For the interval 1906-2001: B2=Bob Allen Core \#0206122, A1=Bob Allen Core \#0206124, R1=Russell Key Core \#0206125, K1=Russell Key Core \#0206127, N1=Ninemile Bank Core \#0208134, T1=Trout Cove Core \#02061211. 


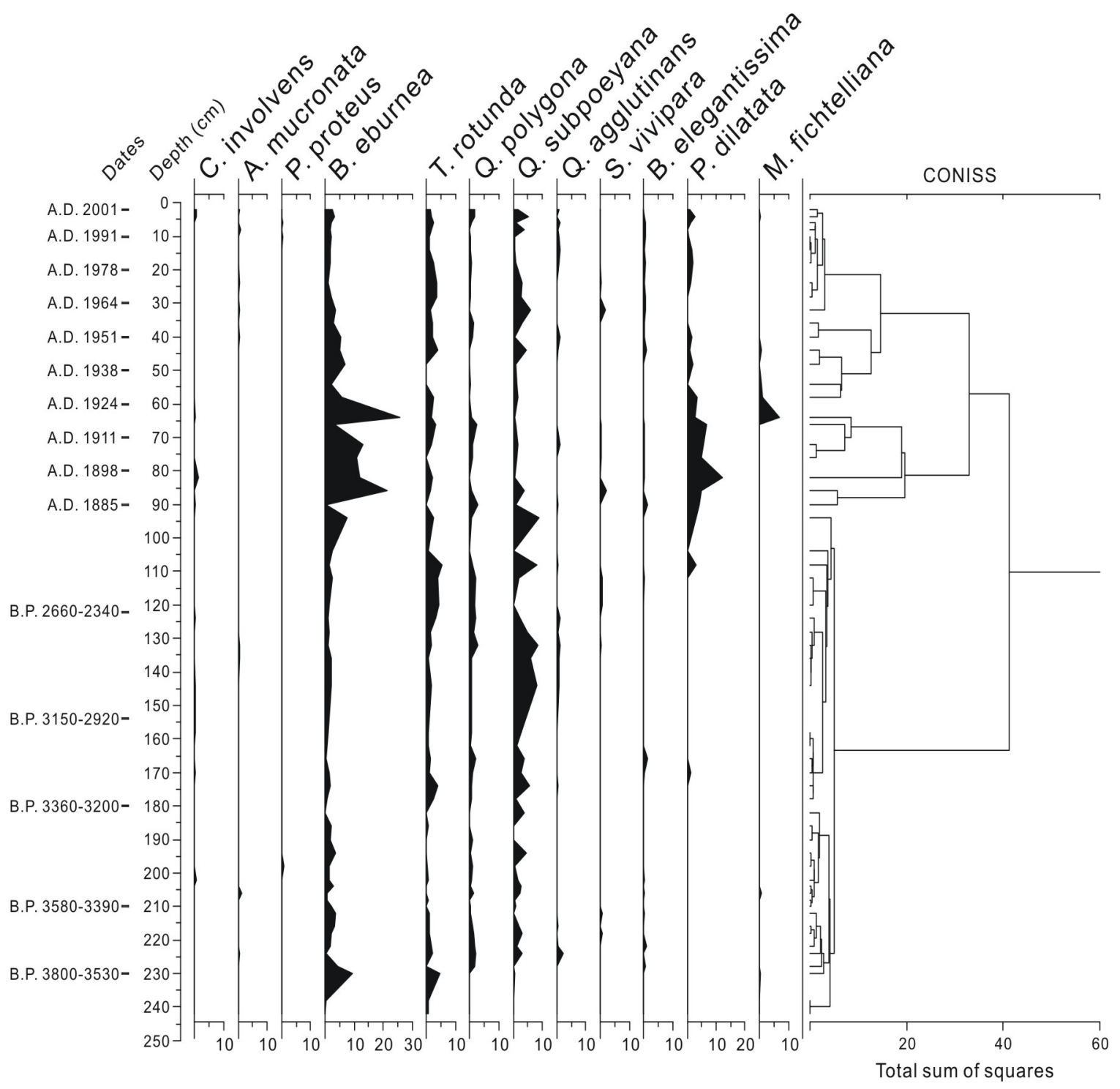

Figure 2.24 Percentages of seagrass-associated foraminifera in Ninemile Bank Core $\# 0208134$. A.D. ages determined with ${ }^{210} \mathrm{~Pb}$ method and B.P. ages determined with ${ }^{14} \mathrm{C}$ dating. Note that the cluster analysis from $90-0 \mathrm{~cm}$ is the same as in Figure 2.18. 


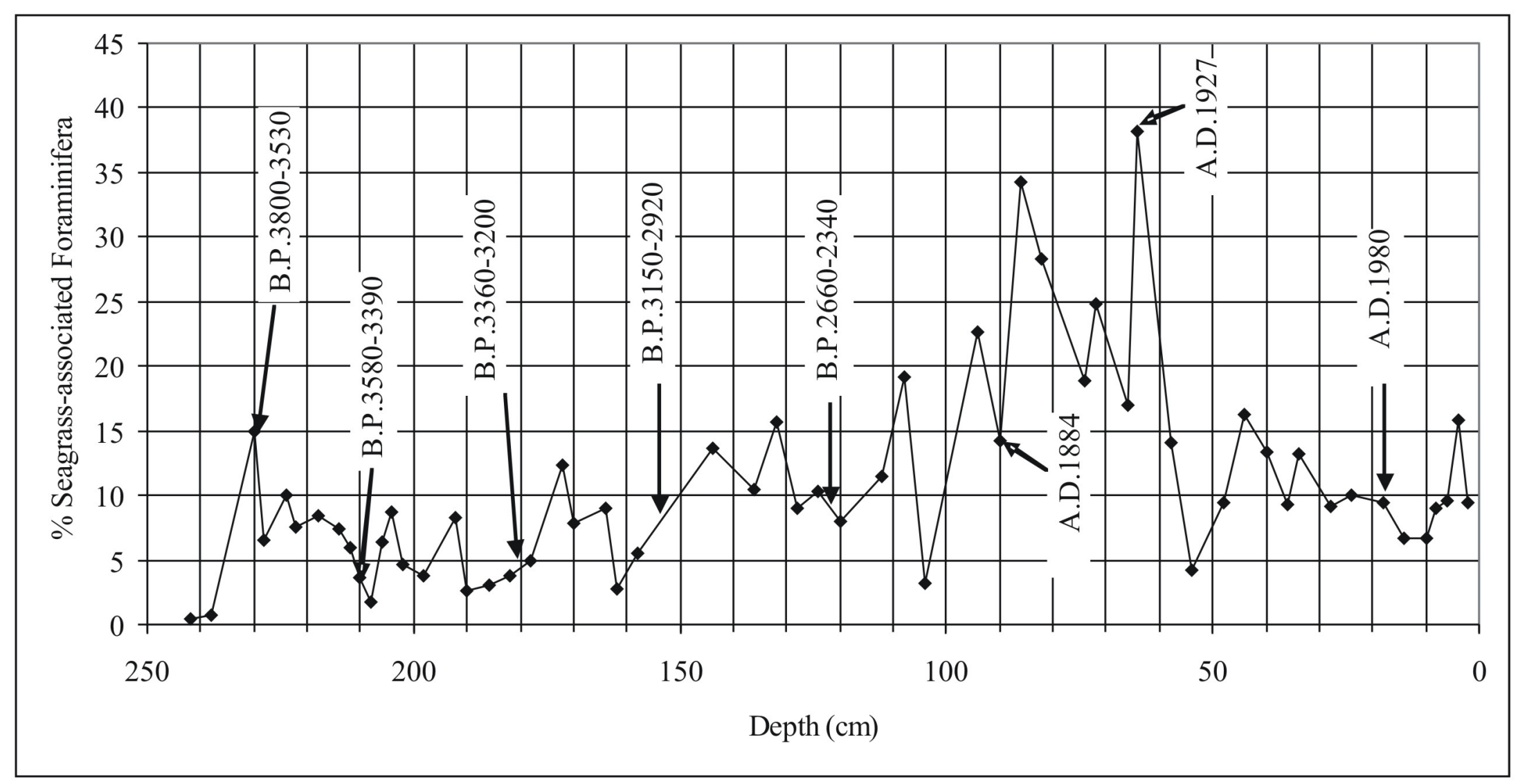

Figure 2.25 Percentages of seagrass-associated foraminifera in Ninemile Bank Core \#0208134, last 4000 years. 


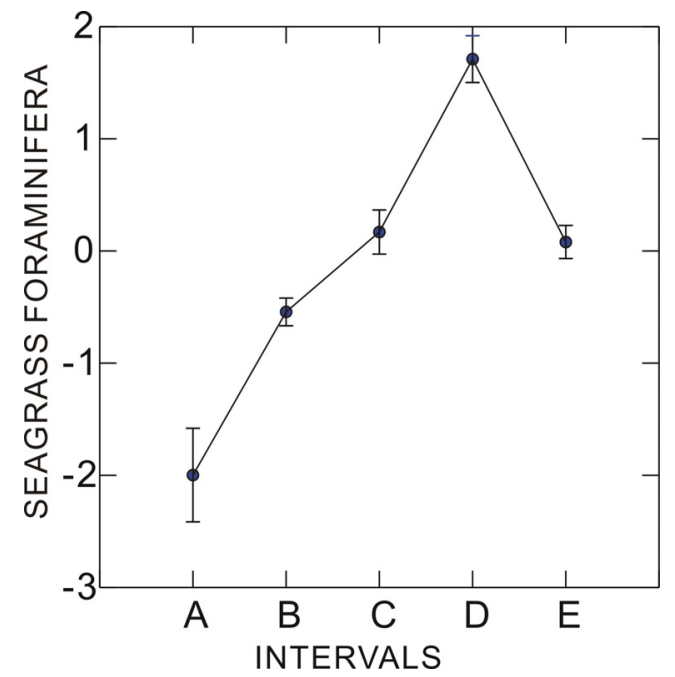

Figure 2.26 ANOVA on all studied samples from Ninemile Bank Core \#0208134, ca. 3800 B.P.-A.D. 2001. Intervals A-E are defined in the text. 


\section{CHAPTER 3}

\section{HISTORICAL SALINITY FLUCTUATION IN FLORIDA BAY}

\section{Introduction}

Rapid ecological changes in Florida Bay from the late 1980s to early 1990s include a seagrass die-off, water turbidity and algal blooms (Fourqurean et al., 1993; Boyer and Fourqurean, 1997). Although the causes of the initial seagrass die-off in 1987 have been related to sulfide toxicity and hypoxia (Carlson et al., 1994), hypersalinity resulting from a multiyear drought starting in 1987 is also believed to have played an important role in this event (Montague and Ley, 1993; Fourqurean et al., 2002; Lirman and Cropper, 2003). Recently, managers have tried to restore the ecosystems in Florida Bay to their anthropogenically unaltered states (Ishman et al., 1997). As an important environmental parameter, salinity records of the past may at least partly illustrate what the original, natural ecosystems were (Brewster-Wingard and Ishman, 1999). The primary purpose of the current research is to trace the historical salinity variations over the past $\sim 120$ years for the purpose of understanding the natural vs. human-induced variability of Florida Bay. Another purpose is to study the long-term salinity variations over the past $\sim 4,000$ years to understand how salinity changed with respect to sea level rise.

Florida Bay is a shallow, triangular, subtropical bay located at the south end of the Florida peninsula (Figure 3.1) and is part of Everglades National Park. It is bordered by coastal levees and mangrove swamps of the Everglades to the north and by the Florida Keys, composed of a Pleistocene reef, to the south and east (Enos and Perkins, 1979). Florida Bay may be divided into four zones by its mud banks (Figure 3.1): eastern, 
central, western and southern Florida Bay (Wanless and Tagett, 1989). Salinity in eastern Florida Bay has varied more than in the other zones because it is closer to the mainland and therefore, more sensitive to the freshwater runoff. Salinity has fluctuated in the eastern bay between 6 and 70 psu, depending on the freshwater input from the Everglades, canal systems and rainfall (Lidz and Rose, 1989). Central Florida Bay has a long history of hypersaline conditions because of limited direct freshwater flow from the Everglades and restricted circulation due to the many mud banks. Values as high as $70 \mathrm{psu}$ were once recorded in the 1950s (Light and Dineen, 1994) and again in the late 1980s (Fourqurean and Robblee, 1999) in the central bay. Salinity in the western bay is relatively stable and normal because of water exchange with the Gulf of Mexico. Southern Florida Bay, north of the keys, has been relatively clear and salinity in this region is normal (Fourqurean et al., 1993).

Historically, freshwater input into the bay was delivered by Taylor Slough (Figure 3.1; McIvor et al., 1994). Natural water circulation may have been first interrupted in 1905 when the Flagler railroad was built from Miami to the Florida Keys (Swart et al., 1996, 1999) and blocked the water exchange between Florida Bay and the Atlantic Ocean. By 1917, four major canals were constructed as part of the Everglades drainage project. Between 1915 and 1928, Tamiami Trail was constructed, linking Miami with Florida's west coast, and cutting off the natural flow of freshwater that had flowed from central Florida southwestward to the bay. Between 1950 and 1985, the Everglades Agriculture Areas, Water Conservation Areas, and more canals and levees were constructed to change the water flow (Light and Dineen, 1994). Around 1985, steps were taken to help restore (or rehabilitate) natural hydrologic conditions within Everglades National Park. 
Previous studies of the historical variability of salinity in Florida Bay have been based on geochemical and paleontological proxies. Swart et al. (1999) used stable isotopes of oxygen from coral reefs of Florida Bay to study salinity variations between 1824 and 1993. They found a generally increasing trend from 1910 to 1993, with the highest salinity between 1950 and 1960. Based on these results, Swart et al. (1999) concluded that prior to 1900 there were large variations in salinity between decades, while in the $20^{\text {th }}$ century the changes were more gradual, with a maximum salinity occurring at about 1955. They related the increasing salinity in the early 1900 s to the construction of the Flagler Railroad from Miami to the Florida Keys between 1905 and 1912, which led to restricted water circulation in the bay (McIvor et al., 1994; Brewster-Wingard and Ishman, 1999). However, the generally increasing trend of salinity after 1930 was attributed to the long-term water management of South Florida (Swart et al., 1996), including canal construction. Besides chemical proxies, the shells of some marine organisms such as mollusks, benthic foraminifera and diatoms, have been used as salinity indicators (Phleger, 1954, 1955; Poag, 1978; Poag, 1981; Lidz and Rose, 1989; Murray, 1991; Ishman et al., 1997; Brewster-Wingard and Ishman, 1999; Ishman, 2000; Huvane and Cooper, 2001; Reinhardt et al., 2003). In this study, historical salinity variations through the past 120 years are reconstructed using the ecology of benthic foraminifera, because certain species are sensitive to environmental parameters such as salinity, substratum, and nutrients.

In general, benthic foraminiferal assemblages of central to south Florida have been divided into three types of faunas based on their salinity preference: brackish fauna, marine fauna and hypersaline fauna (Lidz and Rose, 1989; Brewster-Wingard and Ishman, 
1999; Hill et al., 2003). Increases in species diversity and the proportion of calcareous species generally mark the transition from a brackish environment to a marine environment (Lidz and Rose, 1989). Several studies (Bock, 1969; Rose and Lidz, 1977; Lidz and Rose, 1989) on modern Florida Bay foraminifera reported the distribution of species according to a salinity gradient. The brackish fauna is usually found in mangrove swamps or small bays near the Florida mainland, where there is a large amount of runoff from the Everglades (Lidz and Rose, 1989), and is generally dominated by two species: Ammonia beccarii and Elphidium poeyanum (Hill et al., 2003). Assemblages of the marine fauna are characterized by a high diversity, and species can be divided into two main groups: miliolids and soritids (Lidz and Rose, 1989). The hypersaline fauna is difficult to define because some brackish species can also be found here in small percentages (Murray, 2000). Furthermore, Miliammina fusca, an agglutinated species assumed to mostly appear in the low-salinity environment, may also be found in the hypersaline zone (Murray, 1991). Therefore, the assumption is that the assemblages dominated by miliolids (up to $90 \%$ or $100 \%$ ) indicate a hypersaline environment.

The present study addresses two questions: (1) How has salinity changed on a decadal scale in the last 120 years? (2) How has salinity fluctuated through time on a centennial to millennial scale over the last 4000 years? In order to answer the above questions, the results will be separated into two parts, respectively: (1) More recent historical trends of salinity from $1880-2001$, dated with the ${ }^{210} \mathrm{~Pb}$ method, are compared to the timing of known human-induced events to examine whether anthropogenic vs. natural variability had more effect. (2) Long-term salinity changes, with samples dated using ${ }^{14} \mathrm{C}$, are examined over the past $\sim 4,000$ years. 


\section{Methods}

\section{Coring Sites and Sampling}

Eight sediment cores were collected by the U.S. Geological Survey with a piston-coring device at Bob Allen Bank, Ninemile Bank, Trout Cove and Russell Key in Florida Bay (Figure 3.1, Table 3.1). Two cores (around $100 \mathrm{~m}$ apart) were taken from each site. These sites were selected because they receive different sources of freshwater runoff and seawater. Trout Cove is close to the mainland and is more likely to be affected by the freshwater runoff; Ninemile Bank is furthest from the mainland and the Florida Keys, so it is projected to be minimally affected by human activity, and it is mostly influenced by the Gulf of Mexico; and Bob Allen Bank and Russell Key are located in the central bay and are hypothesized to be more affected by processes on both the mainland and the Keys. All cores were taken through calcareous muds to the limestone substratum and had an average length of $1.5 \mathrm{~m}$. Of these four sites, two (Bob Allen and Ninemile Bank) contained peat at the base. In order to determine the presence of laminations and to evaluate the extent of mixing, each core was x-rayed before sampling. All cores were well bioturbated with few laminations visible. Of these eight cores, only six (two cores each from Bob Allen Bank and Russell Key, and one each from Ninemile Bank and Trout Cove) were analyzed in the study because of time constraints. The details of the selection of the four sites are as follows:

1) Ninemile Bank has a sedimentary record of over 4,000 years (Enos, 1989; Table 3.2). Because it is contiguous with the Gulf of Mexico, it should have had a relatively stable salinity history, less likely to be affected by evaporation and runoff from the mainland, and continuous record of salinity variation because it is furthest from the mainland and 
thus, anthropogenic activity. Therefore, only one core from Ninemile Bank was analyzed as an end member in the bay transect.

2) Bob Allen Bank is near the center of Florida Bay, which could be expected to have more intra- and inter-annual variation in environmental conditions and related salinity fluctuation. Previous studies (Halley and Rouler, 1999; Brewster-Wingard and Ishman, 1999) documented a fairly continuous sedimentary record and salinity changes during the last two decades. Two cores from this area were taken and analyzed for benthic foraminifera.

3) Russell Key, also in central Florida Bay, is a few hundred meters across and about $1 \mathrm{~km}$ long (Cronin et al., 2001). Russell Key accreted in a southward direction (Wanless and Tagett, 1989), and lies much closer to the Everglades mainland than the above two sites. Two cores were taken and analyzed from this area.

Both Bob Allen Bank and Russell Key are strategically situated in the central part of Florida Bay, where the greatest fluctuations in salinity were observed. Salinity up to 70 psu can be expected during the droughts (Fourqurean and Robblee, 1999).

4) The sampling site near Trout Cove is located very close to the mainland in the northeastern bay, so it is more likely to have been affected by freshwater runoff from the Everglades. The salinity might be consistently low in this area because of continuously freshwater input.

The cores were sliced completely into 2-cm-thick samples, which were divided among researchers for anlysis. Each sample was divided into several parts for different research groups: 1/2 was used to determine ages, 1/4 was reserved for nutrient and stable isotope 
studies, $1 / 8$ was used for diatom research, and 1/8 was for foraminiferal research (this study).

\section{Age Determinations}

The method of ${ }^{210} \mathrm{~Pb}$ dating has been used primarily on lake sediments within the time range of 1-150 years. This method is based on the escape of radon gas from the earth into the atmosphere, and the radioactive disequilibrium between ${ }^{210} \mathrm{~Pb}$ and its parent, ${ }^{226} \mathrm{Ra}$ (Holmes et al., 2001). An assumption of the method is that the radium distribution is constant and equal to the value where the total ${ }^{210} \mathrm{~Pb}$ activity is constant with depth. The ${ }^{210} \mathrm{~Pb}$ method of age determination was described by Holmes et al. (2001), who ran the analyses at the U.S. Geological Survey, St. Petersburg, Florida, for this project and contributed ages based on a model for each core. Of the two models that have usually been used to calculate the age, the constant rate of supply model and the constant initial concentration model, the first model is used in this study. The constant rate of supply model assumes that the flux of ${ }^{210} \mathrm{~Pb}$ is constant over time regardless of how the sediment flux might vary, while the constant initial concentration model assumes that the concentration of ${ }^{210} \mathrm{~Pb}$ at time zero (when the sediment was deposited) has been constant over time.

The limitations of ${ }^{210} \mathrm{~Pb}$ dating preclude precise inter-site comparisons of interannual trends, especially during the periods in the late $19^{\text {th }}$ to early $20^{\text {th }}$ centuries when the precision of ${ }^{210} \mathrm{~Pb}$ dating is diminished. Therefore, in this research, only periods between 1880 and 2001 (a span of $\sim 120$ years - the outside limit of the method for these cores) are considered. 
Materials measured by the radiometric technique were analyzed by synthesizing sample carbon to benzene ( $92 \% \mathrm{C})$, measuring for ${ }^{14} \mathrm{C}$ content in one of 53 scintillation spectrometers, and then calculating for radiocarbon age. Marine carbonate samples were corrected for ${ }^{13} \mathrm{C} /{ }^{12} \mathrm{C}$, and both global and local geographic reservoir effects (Stuiver, et al., 1998). The calibations were calculated using the latest (1998) calibration database (Stuiver, et al., 1998; Talma and Vogel, 1993). Ages (Table 3.2) have the units "B.P." (Before Present), where "Present" is defined as A.D. 1950 for the purposes of radiocarbon dating.

\section{Preparation and Identification of Benthic Foraminifera}

Two hundred and three sediment samples were soaked in freshwater to disaggregate sediments, then sieved to obtain grain sizes $>63 \mu \mathrm{m}$, which includes all adult and nearly all juvenile foraminifera. The sample residues were split until 300-400 specimens (a statistically significant sample) could be picked from a sample split (Murray, 1991). The foraminifera were picked, sorted onto cardboard slides and identified to species under the light microscope.

There is considerable taxonomic and ecological data on benthic foraminiferal populations collected from bays and estuaries along the Atlantic and Gulf of Mexico coasts. Species were identified following the taxonomy of Bock et al. (1971), Rose and Lidz (1977), Wantland (1967), and Buzas and Severin (1982). The identifications in many cases were checked against type specimens at the U.S. National Museum of Natural History. The Catalogue of Foraminifera (Ellis and Messina, 1941-2009) was used for the original descriptions of species. The full names of taxa are listed in Appendix 1. 
Two distinct benthic foraminiferal assemblages (Table 3.3), a brackish fauna and a marine fauna, are defined based on previous studies of Florida Bay (Bock, 1971; Rose and Lidz, 1977; Lidz and Rose, 1989; Murray, 1991; Ishman et al., 1997; BrewsterWingard and Ishman, 1999). The brackish fauna, generally dominating the benthic faunal assemblages in polyhaline environments, is mostly represented by highly abundant Ammonia beccarii, which makes up 20\% to 60\%, and Elphidium spp., with frequencies similar to Ammonia beccarii. Within the brackish fauna, some inflated miliolids such as Quinqueloculina tenagos, Heterillina cribrostoma and Triloculina rotunda may be occasionally present in low frequency (Lidz and Rose, 1989). The marine fauna, which normally dominates in euhaline environments, consists of mostly miliolids and only a few soritid species (Table 3.3). Among them, H. cribrostoma and Q. bosciana are the most abundant species. Generally, when a marine fauna is present in a foraminiferal assemblage with the abundance of more than $50 \%$, it will be considered the dominant fauna in this study. Salinity is interpreted as above $30 \mathrm{psu}$ when the marine fauna dominates the assemblages (Lidz and Rose, 1989; Murray, 1991; Brewster-Wingard and Ishman, 1999; Hill et al., 2003).

\section{Data Analysis}

Counts of species in any sample were transformed from percentage data using the relationship $2 \arcsin \mathrm{p}^{1 / 2}$, where $\mathrm{p}=$ percentage datum (Collins, 1993). Three statistical methods were used to analyze the results, as follows: The stratigraphically constrained cluster analysis CONISS (Grimm, 1987) was performed to determine the associations between certain foraminiferal distributions. This is a program that performs cluster analysis by incremental sums of squares, with the constraint that only adjacent core 
samples can be merged. Analysis of variance (ANOVA) was used to test the variations of species' proportions among independent intervals of time (defined in Table 3.4) to identify statistically significant trends through time. The samples of each core were assigned to six different intervals based on the time when well-known natural or anthropogenic events occurred (Table 3.4).

Discriminant analysis, related to both multivariate analysis of variance and multiple regression, was used to investigate how similar the samples from the four areas were. In discriminant analysis, Wilks' lamba, the same test used in the multivariate ANOVAs, is used to test multivariate differences among groups and investigate which groups are most alike and most different (Engelman, 2004).

\section{Results}

\section{Historical Salinity, 1880-2001}

A total of 76 benthic foraminiferal species from 203 samples collected from six cores of Florida Bay were identified. The foraminiferal assemblages are dominated by calcareous forms with agglutinated species constituting a minor component in most of the assemblages $(<1 \%)$. The most abundant taxa are Discorbidae, Rotaliidae, Elphidiidae and Miliolidae. Soritidae such as Archaias angulatus, Articulina mucromata, Peneroplis proteus and Spiroculina exima appear at fairly low frequencies. The generally occurring hyaline species include Ammonia beccarii, Elphidium galvenstonense, Elphidium poeyanum, Elphidium mexicanum and Haynesina depressulum. The common miliolids include Heterillina cribrostoma, Triloculina fitterei, T. rotunda, Biloculina. eburnea, Quinqueloculina akneriana, Q. bosciana, Q. polygona, Q. poeyana, $Q$. subpoeyana and 
Pateoris dilatata. Other miliolids occurring in very low frequency include $Q$. angulatus, Q. agglutinans, Q. bicornis, Q. bidentata, Q. laevigata and Pyrgo elongata. Agglutinated taxa in this core include Ammobaculites exiguus and Clavulina tricarinata.

(1) Bob Allen Bank Core \#0206122: The most abundant species are $A$. beccarii, $B$. eburnea, Elphidium spp., H. cribrostoma, Q. bosciana, Q. poeyana, Q. subpoeyana and $T$. fitterei (Figure 3.2). Ammonia beccarii, whose abundance can have a strongly inverse relationship with salinity (Brewster-Wingard and Ishman, 1999), reached its highest abundance during the late 1900s through the early 1940s. Elphidium spp. show high frequencies from the late 1880 s to the early 1940s. Three typical marine fauna, Heterillina cribrostoma, Q. bosciana and T. fitterei, fluctuated remarkably similarly with relatively higher abundance after 1940 , when $A$. beccarii was much less common, with percent abundances of $5 \%$ or less. Biloculina eburnea fluctuated with minor amplitude except during the early 1950s, when it reached its maximum abundance. Quinqueloculina poeyana and $Q$. subpoeyana show changes in abundance, ranging 1-5\% in lower core samples, and increasing to about $10 \%$ around 1990 .

The cluster analysis (Figure 3.2) clearly divides the samples into three main groups: one large cluster including the two groups from $78-66 \mathrm{~cm}(1889-1906)$ and $62-48 \mathrm{~cm}$ (1913-1934), and another large cluster from 42-2 cm (1943-2001). The first group (78-66 $\mathrm{cm})$ and the third group $(42-2 \mathrm{~cm})$ are characterized by the relatively high abundance of the marine fauna and the second group $(62-48 \mathrm{~cm})$ has a relatively high abundance of $A$. beccarii and Elphidium spp. Results of an ANOVA (Figure 3.3) indicate that the change in salinity is significantly different across intervals (overall $\mathrm{p}=0.03$ ). The salinity in Interval 2 is significantly different from other intervals $(\mathrm{p}=0.001)$. 
(2) Bob Allen Bank Core \#0206124: The most abundant species are A. beccarii, Elphidium spp., B. eburnea, H. cribrostoma and Q. bosciana (Figure 3.4). Both A. beccarii and Elphidium spp. are more abundant in the lower samples which were deposited before the early 1930s. Biloculina eburnea had two peaks in abundance during the 1910s through 1920s and during the 1970s through 1980s, respectively. Heterillina cribrostoma and Q. bosciana show relatively higher abundance after 1932.

The cluster analysis (Figure 3.4) separates the samples into two main groups: $40-22 \mathrm{~cm}$ (1883-1932), and 20-2 cm (1937-1987). Both groups are characterized by a high abundance of the marine fauna, especially H. cribrostoma and Q. bosciana. The older group is characterized by a high abundance of species such as $A$. beccarii and Elphidium spp. which prefer oligohaline conditions. The results of an ANOVA (Figure 3.5) indicate that the salinity is not significantly different overall $(p=0.071)$. However, Intervals 4 and 5 are significantly different from 1 and $2(p=0.04)$.

Trends in the percentages of the marine fauna through time (Figure 3.6) for the two cores from Bob Allen Bank show fluctuations that are similar to the cluster analysis results. From approximately 1880-1905, the marine fauna dominated benthic foraminiferal assemblages. Around the turn of the $20^{\text {th }}$ century, the benthic foraminiferal assemblages shifted to domination by the brackish fauna. After 1940, the fauna was dominated again by the marine fauna.

(3) Russell Key Core \#0206125: The most abundant species include $A$. beccarii, $B$. eburnea, Elphidium spp., H. cribrostoma, Q. bosciana and Triloculina fitterei (Figure 3.7). Ammonia beccarii and Elphidium spp. were low in abundance between 1884 and 1960 except for two short periods during the 1880s and 1928-1937. After 1960, their 
abundance gradually increased towards 2001 . Heterillina cribrostoma was abundant through the whole period with a maximum value around 1910. Biloculina eburnea was more abundant before 1967, while T. fitterei was less abundant during this period. Quinqueloculina bosciana, which was almost always abundant throughout the core, shows a minimum abundance during the 1930s.

Based on the cluster analysis, two groups are identified (Figure 3.7): one cluster from $140-116 \mathrm{~cm}$ (1884-1905) and another cluster from 108-2 cm (1911-2001). The younger cluster contains two subclusters: 108-46 cm (1911-1964), and 42-2 cm (1967-2001). The results of an ANOVA (Figure 3.8) indicate that the salinity trend over the entire studied period is not significant $(\mathrm{p}=0.33)$. However, the Intervals 1 and 2 are significantly different from Intervals 4 and $6(\mathrm{p}=0.04)$.

(4) Russell Key Core \#0206127: The most abundant species include $A$. beccarii, $B$. eburnea, Elphidium spp., H. clribrostoma, Q. bosciana, T. fitterei and T. rotunda (Figure 3.9). Ammonia beccarii shows a gradual increase between 1932 and 2001. Elphidium spp. were more abundant between 1932 and 1980. Heterillina cribrostoma was high in abundance between 1920 and 1955, significantly lower between 1962 and 1980, then slightly increased between 1983 and 2001. Biloculina eburnea and T. fitterei fluctuated similarly. They were less abundant in the middle core between the late 1930s and the early 1980 s.

The cluster analysis (Figure 3.9) separates the samples into two groups: one large cluster from 148-82 cm (1919-1955), and another large cluster from 70-2 cm (1962-2001). The results of an ANOVA (Figure 3.10) indicate that the salinity differences between intervals is not significant $(\mathrm{p}=0.23)$. The change in salinity from Interval 2 to 4 is gradual 
and not significant between adjacent intervals, but it is significant between Intervals 2 and 4.

The trends in percentages of the marine fauna in the two cores from Russell Key, as with Bob Allen Bank, also display remarkably similar changes (Figure 3.6). During the periods of 1880-1920 and 1940-1960, the assemblages were dominated by the marine fauna. Immediately following these two periods, the marine species were slightly less abundant. However, there was a short peak during the late 1980s and the early 1990s.

(5) Ninemile Bank Core \#0208134: The most abundant species are $A$. beccarii, Elphidium spp., B. eburnea, H. cribrostoma, Q. bosciana and Q. poeyana (Figure 3.11). Soritidae are more abundant in this core than they are in the Bob Allen Bank cores and Russell Key cores. Agglutinated species are present at low frequencies in this core. Ammonia beccarii composes around $10 \%$ of the assemblage throughout the core, was more abundant after 1932, and reached its maximum abundance in 1980. Elphidium spp. in this core are much more abundant than $A$. beccarii, with maximum abundance occurring in 1932-1951. Heterillina cribrostoma and B. eburnea were high in abundance in the lower core samples between 1885 and 1919, and then dramatically decreased around 1927. Heterillina cribrostoma increased in abundance around 1986-1993, while $B$. eburnea remained low. Quinqueloculina bosciana was most abundant before the 1930s. Two major clusters can be identified in a cluster analysis (Figure 3.11): 90-64 cm (1885-1919), and 58-2 cm (1927-2001). The oldest cluster, from 1885 to 1919, was dominated by the marine fauna. Between 1932 and 2001, there was a short term (19321951) when the assemblage was dominated by the brackish fauna. ANOVA (Figure 3.12) results indicate that the change in salinity between intervals is overall significant $(p=0.04)$, 
and the salinity in Intervals 1 to 2 is significantly different from that of Intervals 3 to 6 $(p=0.02)$.

The percentages of the marine fauna at Ninemile Bank behave differently from the other cores (Figure 3.6). The marine fauna dominated in the lower core samples between 1880 and 1930. Between 1930 and 2001, the foraminiferal assemblages were composed of the marine fauna $(\sim 35 \%)$, the brackish fauna $(\sim 25 \%)$ and Haynesina depressula $(\sim 25 \%)$ except for a short period around 1991 when the marine fauna dominated. Haynesina depressula is an infaunal species preferring an intertidal-subtidal habitat and is not associated with a specific range of salinities.

(6) Trout Cove Core \#02061211: The most abundant species are $A$. beccarii, Elphidium spp., H. cribrostoma, Q. bosciana and T. rotunda (Figure 3.13). Ammonia beccarii remained fairly steady throughout the whole period. Elphidium spp. were the most dominant group and were stable between 1880 and 1932, after which they fluctuated with a relatively high amplitude and with a higher average value. Heterillina cribrostoma, Quinqueloculina bosciana and T. rotunda were stable but relatively low in abundance when compared to the brackish fauna.

The CONISS cluster analysis (Figure 3.13) separates all the samples into two main clusters: 46-42 (1880-1891), and 38-2 (1901-1994). An ANOVA (Figure 3.14) shows that the change in salinity between intervals is not significant overall $(p=0.23)$. Interval 4 is significantly different from Intervals 3 and $5(\mathrm{p}=0.02)$.

The Trout Cove assemblages display a much different pattern from the other cores (Figure 3.6). The benthic fauna was dominated by a brackish fauna with minor fluctuations throughout the whole period. 
(7) Discriminant Analysis. All samples of foraminifera younger than 1880 were tested with discriminant analysis (Figure 3.15 ) to identify the salinity among cores. The percentages of the marine fauna (transformed with $\arcsin \mathrm{p}^{1 / 2}$ ) comprised the data set. The samples from Ninemile Bank and Trout Cove are clearly distinguished from each other and from those in the central bay. The samples from the central bay cannot be separated from each other by either site or core, indicating the most similar salinities between Bob Allen Bank and Russell Key.

\section{Long-term Salinity Fluctuations, Over the Past 4000 Years}

The core from Ninemile Bank, with ${ }^{14} \mathrm{C}$ ages as old as $\sim 4000$ years B.P., was investigated for long-term trends. The most abundant taxa are A. beccarii, Elphidium spp., B. eburnea, H. cribrostoma, Q. bosciana, Q. poeyana and T. rotunda (Figure 3.16). Ammonia beccarii and Elphidium spp. are extremely abundant in the samples from 242$238 \mathrm{~cm}$ (peat samples), $180-110 \mathrm{~cm}$ and $60-20 \mathrm{~cm}$. Heterillina cribrostoma and $Q$. bosciana behave similarly and have high abundances at $235-180 \mathrm{~cm}, 110-60 \mathrm{~cm}$ and $20-2$ cm. Biloculina eburnea and Q. poeyana are most abundant at 90-60 cm. Triloculina rotunda shows a high abundance in the lower core samples between $230-170 \mathrm{~cm}$.

The cluster analysis (Figure 3.16) clearly separates the samples into five main clusters: (1) $242-238 \mathrm{~cm}$, (2) $230-182 \mathrm{~cm}$, (3) $178-112 \mathrm{~cm}$, (4) $108-58 \mathrm{~cm}$ and (5) $54-2 \mathrm{~cm}$. Cluster 1 is characterized by the extreme high frequencies of $A$. beccarii and Elphidium spp. and the absence of miliolids. Clusters 2 and 4 are marked by the relatively high abundance of the marine fauna, especially H. cribrostoma and Q. bosciana. Within Clusters 3 and 5, 
Ammonia beccarii and Elphidium spp. dominate the benthic foraminiferal assemblage, along with a significant decrease in the marine fauna.

The percentage of the marine fauna (Figure 3.17) was extremely low in abundance (near $0 \%$ ) in the bottom (peat) samples, then dramatically increased around B.P 38003530 to around $60 \%$ and remained high until B.P. $3630-3200$, when it decreased to a lower level, around 40\%. It then fluctuated at these lower levels until about B.P. 26602340 , when it increased to a maximum of $\sim 80 \%$ in A.D. 1919 . After this, it dramatically decreased to a value less than $20 \%$, and then gradually increased with smaller fluctuations to around $40 \%$.

\section{Discussion}

\section{Historical Salinity, 1880-2001}

Below, patterns of salinity as interpreted from benthic foraminiferal assemblages are compared across the four studied areas through the last $\sim 120$ years. The most distinctly different pattern in the percentage of the marine fauna is for Trout Cove (Figs. 3.6 and 3.13). Throughout the whole period, the salinity indicated by the high percentages of the brackish fauna, mostly Ammonia beccarii and Elphidium spp. (Figure 3.13), suggest a consistently brackish environment between 1880 and 1994 (top of core). Salinities measured by the South Florida Water Management District (http://serc.fiu.edu/wqmnetwork/SFWMD-CD/Pages/FB.htm) are available from 1991 and show an average of low salinity around 15 psu at Trout Cove between 1991 and 1994, indicating a brackish environment, which agrees with my data. Trout Cove is the nearest site to the mainland and therefore, more likely to have been affected by freshwater flow 
from the Everglades and canals into the bay. In recent decades, the freshwater discharge from canals has depended upon the operational policies of the South Florida Water Management District, which determines their timing (Light and Dineen, 1994). Through the dry and wet seasons, a range of $35 \mathrm{psu}$ (from freshwater to saltwater) is expected in a normal year (McIvor et al., 1994; Sklar et al., 2002). The fact that the marine fauna never dominated the Trout Cove assemblages indicates a long-term, oligohaline to polyhaline environment. Relatively higher salinities were not recorded by the benthic faunal assemblages, probably because the time periods with a more saline environment are not long enough for benthic foraminifera to finish a life cycle (typically three months). Furthermore, an ANOVA (Figure 3.14) also suggests that the changes of salinity within intervals are not significant $(\mathrm{p}=0.22)$.

Ninemile Bank also showed a different trend in salinity variation from the other cores, suggested by the abundance of the marine and brackish faunas (Figure 3.6). The marine fauna dominated the assemblages and continued to increase from 1880 to 1920 , indicating a euhaline environment. Significant changes in salinity occurred during the 1920 s, indicated by a sudden increase in the brackish fauna. This agrees with the occurrence of frequent hurricanes and their associated higher precipitation during the late 1920s (Table 3.4, Light and Dineen, 1994), which generally reduces the salinity of the bay (Kelble et al., 2007). Furthermore, the low salinity may also be related to higher rainfall associated with the Atlantic Multidecadal Oscillation (AMO) cool phases between 1905 and 1930 (Enfield et al., 2001). Between 1940 and 2001, except for a short period around 1990, the marine fauna (an average of $\sim 35 \%$ ) showed slightly higher abundance than the brackish fauna ( an average of $\sim 25 \%$ ) indicating salinity above 30 
psu. The high abundance of the marine fauna (>50\%) at around 1990 may be the result of a multi-year drought and its related high salinity occurring during the late 1980s, which agrees with the salinity monitored by the stations near Ninemile Bank showing that salinity was highest at $\sim 1989$ to 1990 with an average of 40 psu during a short period of 1989-1991. After 1991, the salinity decreased and fluctuated around $31 \mathrm{psu}$ (http://serc.fiu.edu/wqmnetwork/SFWMD-CD/Pages/FB.htm), which agrees with the results indicating that salinity was above 30 psu between 1991 and 2001. Between 1940 and 2001, the high frequencies of Haynesina depressula, an intertidal-subtidal, infaunal foraminiferal species (Murray, 1991; Scott et al., 2001), may indicate a more organic-rich, lower oxygen environment (Sen Gupta, 1999). This is further confirmed by the relatively high abundance of Bolivina spp., which prefer living in such an environment (Sen Gupta, 1999).

Over the past 120 years, the marine fauna showed larger changes in the central and western bay than in the eastern bay, suggesting greater variations in salinity on a seasonal scale away from the mainland. Salinity would have been affected on this longer time scale by canal construction on the mainland, which caused changes in runoff points along the Everglades boundary (Nuttle et al., 2000). Moreover, the frequency of hurricanes, droughts and phases of the AMO also contributed to changes in the bay's salinity. The changes in foraminiferal assemblages in the Bob Allen Bank cores, Russell Key cores and Ninemile Bank are discussed below by interval.

Within Interval 1, between 1880 and 1904, the percentages of the marine fauna gradually decreased in the two Bob Allen Bank cores and the Ninemile Bank core, but increased in Russell Key Core \#0206125. However, the marine fauna always dominated 
all of these assemblages, suggesting normal marine conditions. During this interval, before the beginning of anthropogenic changes to the mainland and keys, the salinity variation should have reflected only natural environmental changes.

In Interval 2, 1905-1936, the percentages of the marine fauna (Figure 3.6) indicate that the largest change in salinity occurred across all five cores (excluding Trout Cove). In the Bob Allen Bank cores, the largest shift in benthic foraminiferal assemblages, from marine to brackish faunas, occurred at around 1905, suggesting brackish conditions. In the Russell Key cores, a shift from the marine fauna to the brackish fauna occurred later, at around 1925. A plausible reason for this early salinity change around 1905 at Bob Allen Bank is the filling of nearby marine passages required for the 1905-1912 construction of the Flagler Railroad to Key West. This blocked much of the water exchange with the Atlantic Ocean (Swart et al., 1996) and may have resulted in lower salinity conditions. Russell Key is farther from the Keys and closer to the extended mainland than Bob Allen Bank (Figure 3.1), and therefore would have been less affected by this event. Similar to the salinity at Bob Allen Bank, brackish conditions at Russell Key lasted until the late 1930s, when the assemblages started to shift back to the marine fauna (although at Ninemile Bank they remained low, $\sim 20 \%-40 \%$ ). The generally lower salinity occurring in the central bay before 1936 might be related to an AMO cool phase (Enfield et al., 2001) between 1905 and 1925, when higher precipitation occurred, and also to the frequent hurricanes causing high precipitation during the 1920s and 1930s (Table 3.4, Light and Dineen, 1994).

At the beginning of Interval 3, 1937-1959, salinity strongly increased in the central bay, as indicated by the dramatic increase in the percentages of the marine fauna at Bob Allen 
Bank and Russell Key. This agrees with some other studies (Brewster-Wingard et al., 1997; Brewster-Wingard and Ishman, 1999; Huvane and Cooper, 2001) that show an incease in salinity at Russell Key during this period. After this, the relatively high abundance (about $60-80 \%$ ) of the marine fauna suggests high salinity, maybe a hypersaline environment, which may have been due to the natural events of the multiyear droughts in the early 1940s and mid-1950s.

During Interval 4, 1960-1984, the percentages of the marine fauna, although slightly lower, indicate normal marine conditions at Bob Allen Bank and Russell Key. A slight decrease in salinity during this interval was also recorded in other cores from Russell Key by diatoms and mollusks (Brewster-Wingard et al., 1997; Huvane and Cooper, 2001). In addition to the construction of canals and water retention areas (Table 3.4), the consistently marine conditions might also be related to a decreased frequency of hurricanes associated with lower rainfall (Swart et al., 1996).

During Interval 5, 1985-1992 (which has a smaller age error of \pm 2 years), there was a sharp increase in salinity seen in all cores around 1990, indicated by peaks in the percentages of the marine fauna of around $85 \%$ in the central bay, and by the highest values recorded at Ninemile Bank and Trout Cove after $\sim 1940$ (Figure 3.6). The peaks correspond to the drought occurring at the end of the 1980s (Fourqurean and Robblee, 1999), and the high values at both normal and lower salinity sites suggest hypersaline conditions (Hill et al., 2003) in the central bay. This agrees with the salinity data collected in monitoring by the South Florida Water Management District which show salinities of around 40-50 psu in the central bay between 1989 and 1991, dropping to an average of 35 
psu between 1991 and 1995, and 32 psu afterwards

(http://serc.fiu.edu/wqmnetwork/SFWMD-CD/Pages/FB.htm).

Discriminant analysis (Figure 3.15) indicates that salinity variations at Ninemile Bank in the western bay and Trout Cove in the eastern bay were significantly different from those at Bob Allen Bank and Russell Key in the central bay. Ninemile Bank is far from the mainland and keys, and would probably have been less affected by anthropogenic activities and thus more affected by natural events. Trout Cove is next to the mainland and was greatly affected by the changes in freshwater flow caused by human activities. Hypothetically, freshwater flow to the central portion of Florida Bay may occur through the highly porous Miami Limestone Formation (Schomer and Drew, 1982), although the frequency and magnitude is unknown (McIvor et al., 1994). Cores from both central bay sites show great fluctuations in salinity. Bob Allen Bank is closer to the Florida Keys, whereas Russell Key is closer to the mainland; therefore, they would probably have been affected to different degrees by nearby anthropogenic activities. For example, the 19051912 construction of the Flagler Railroad which limited the water exchange between Florida Bay and the Atlantic Ocean had more effect on Bob Allen Bank, while the construction of Tamiami Trail, canals and levees in south Florida would probably have had more effect on Russell Key. This was probably why salinity fluctuations occurred in different periods in two areas.

\section{Long-term Salinity Fluctuations, Over the Past $\sim 4000$ Years}

Salinity was very low at Ninemile Bank before B.P. 3800-3530 (Figure 3.17), as

indicated by the extremely high percentage of the brackish fauna. This also agrees with 
the fact that marine water entered Florida Bay around 4,000 years ago (Enos, 1989). Before that, the area that is now Florida Bay was part of the extended Everglades and contained only freshwater. Mangrove peats marking the base of the Ninemile Bank core verify this. When marine water entered Florida Bay, the benthic foraminiferal fauna abruptly shifted from a brackish fauna to a marine fauna (Figs. 3.13 and 3.14). Ammonia beccarii and Elphidium spp. were replaced by miliolid-dominated assemblages that had higher percentages of species such as $H$. cribrostoma, Q. bosciana and T. rotunda during this period. Around B.P. 3360-3200, another significant change in benthic faunal assemblages occurred. The marine fauna became less abundant $(25 \%$ to $<50 \%)$ between B.P. $3360-3200$ and B.P. $2660-2340$, indicating that salinity was relatively low. Since Ninemile Bank is located in the western bay, it primarily exchanges water with the Gulf of Mexico and receives little freshwater from the keys or mainland. Possible reasons for this drop could be high precipitation, or sea-level regression (Fairbridge, 1974; Froede, 2002) which would bring the mainland closer and result in low salinity. After that time, salinity increased again and remained at its highest levels until A.D. 1927, after which it shifted to a marine (salinity slight above $30 \mathrm{psu}$ ), more organic-rich environment (see section IV. 1, above).

\section{Conclusions}

Changes in ecosystems take place on many scales, including daily, decadal, centennial and millennial. Benthic foraminifera generally are tolerant of short-term perturbations in their environment, but they will respond to seasonal and annual changes in salinity.

Therefore, observations of down-core benthic foraminiferal assemblages have been used 
in this and previous studies to illustrate the historical changes in salinity. Numerous studies have documented associations of benthic foraminiferal species with salinity. All six cores show changes in benthic foraminiferal assemblages through time that are alternations in patterns of dominance between marine and brackish faunas.

Of the six cores examined in this study, the results for the Ninemile Bank core from western Florida Bay and the Trout Cove core from the northeastern bay are much different than results for the Bob Allen Bank and Russell Key cores from the central bay. Ninemile Bank was less affected by anthropogenic activities, but salinity was greatly reduced $\sim 1927-1932$, and then returned to normal marine conditions with salinity higher than 30 psu at $\sim 1946$. The large salinity drop may be related to high precipitation rates caused by frequent hurricanes, associated with a 1905-1925 AMO cool phase. Trout Cove is next to the mainland and has received far more freshwater input from the Everglades than have the other sites. This may be why benthic foraminiferal assemblages have been dominated by the brackish fauna throughout the core. At the central bay sites, Bob Allen Bank and Russell Key, the benthic foraminiferal assemblages have shown more shifts between the marine fauna and brackish fauna. The changes that occurred between 1905 and 1940 at Bob Allen Bank and again between 1925 and 1935 at Russell Key indicate shifts toward less saline conditions. This timing of lowered salinity corresponds to the construction of the Flagler Railroad in the western Florida Keys, and canals and levees in the Everglades. Between 1905 and 1940, during the AMO cool phases, average rainfall increased with a higher frequency of hurricanes in South Florida. This climate change may be the main reason responsible for the low salinity in the central bay. Futhermore, substantial human alteration of the environment occurred between approximately 1940 
and 2001, when benthic foraminiferal assemblages at Bob Allen Bank and Russell Key were mainly dominated by the marine fauna, suggesting consistently marine conditions.

On a centennial to millennial scale, at Ninemile Bank, benthic foraminiferal assemblages clearly show that marine water entered the western Florida Bay before B.P. 3800-3530, probably $\sim 4000$ years ago (Enos, 1989). Since then, salinity has fluctuated in the long term. Two large drops in the percentage of the marine fauna can be observed over the past 4,000 years. The first drop between B.P. $3360-3200$ and B.P. $2660-2340$ might be related to high precipitation or lowered sea level (Froede, 2002). Although there was a second drop in the percentage of the marine fauna around 1927, after which it remained lower, values were higher than for the brackish fauna, indicating a marine environment with salinity above $30 \mathrm{psu}$. 


\section{REFERENCES}

Bock, W. D., 1969, Thalassia testudinum, a habitat and means of dispersal for shallow water benthonic foraminifera: Gulf Coast Association of Geological Societies Transactions, v. 19, p. 337-340.

Bock, W. D., Lynts, G. W., Smith, S., Wright, R., Hay, W. W., and Jones, J. I., 1971, A symposium of recent south Florida Foraminifera: Miami Gelogical Society, Memoir I, $245 \mathrm{pp}$.

Boyer, J. N., and Fourqurean, J. W., 1997, Spatial characterization of water quality in Florida Bay and Whitewater Bay by multivariate analyses: zones of similar influence: Estuaries, v. 20, p. 743-758.

Brewster-Wingard, G. L, Ishman, S. E., Willard, D. A., Edwards, L. E., and Holmes, C. W., 1997, Preliminary paleontologic report on cores 19A and 19B, from Russell Bank, Everglades National Park, Florida Bay: U.S. Geological Survey Opern-file Report 97-460, $29 \mathrm{pp}$.

Brewster-Wingard, G. L., and Ishman, S. E., 1999, Historical trends in salinity and substrate in central Florida Bay: a paleoecological reconstruction using modern analogue data: Estuaries, v. 22, p. 369-383.

Buzas, M. A., and Severin, K. P., 1982, Distribution and systematics of foraminifera in the Indian River, Florida: Smithsonian Contributions to the Marine Sciences, no. 16, 45 pp.

Carlson, P. R., Yarbro, L. A., and Barber, T. A., 1994, Relationship of sediment sulfide to mortality of Thalassia testudinum in Florida Bay: Bulletin of Marine Science, v. 54, p. 733-746.

Collins, Laurel S., 1993, Neogene paleoenvironments of the Bocas Del Toro Basin, Panama: Journal of Paleontology, v. 67, p. 699-710.

Cronin, T. M., Holmes, C. W., Wingard, G., Ishman, S., Dowsett. H., and Waibel, N., 2001, Historical trends in epiphytal ostracodes from Florida Bay: Implications for seagrass and macro-benthic algal variability: Bulletins of American Paleotology, v. 361, p. 159-197.

Ellis, B. F., and Messina, Angelina R., 1941-2009, Catalogue of Foraminifera, v. 106, 87,000 pp., online: Micropaleontology Press, N.Y.

Enfield, D. B., Mestas-Nunez, A. M., and Trimble, P. J., 2001, The Atlantic multidecadal oscillation and its relation to rainfall and river flows in the continental U. S.: Geophysical Research Letters, v. 28, p. 2077-2080. 
Engelman, Laszlo, 2004, Discriminant Analysis: SYSTAT 11, Statistics I, p. 301-358.

Enos, P., 1989, Islands in the bay-a key habitat of Florida Bay: Bulletin of Marine Science, v. 44, p. 365-386.

Enos, P., and Perkins, R. D., 1979, Evolution of Florida Bay from island stratigraphy: The Geological Society of American Bulletin, v. 90, p. 59-83.

Fairbridge, R. W., 1974, The Holocene sea-level record in south Florida, in Environments of south Florida: present and past, in Gleason P. J., ed., Miami Geological Society, Memoir 2. pp. 223-232.

Fourqurean, J. W., Jones, R. D., and Zieman, J. C., 1993, Processes influencing water column nutrient characteristics and phosphorus limitation of phytoplankton biomass in Florida Bay, FL, USA: Inference from spatial distributions: Estuarine Coastal and Shelf Science, v. 35, p. 295-314.

Fourqurean, J. W., and Robblee, M. B., 1999, Florida Bay: a history of recent ecological changes: Estuaries, v. 22, p. 345-357.

Fourqurean, J. W., Durako, M. J., Hall, M. O., and Hefty, L. N., 2002, Seagrass distribution in south Florida: a multi-agency coordinated monitoring program: The Everglades, Florida Bay, and Coral Reefs of the Florida Keys: An Ecosystem Sourcebook, (eds. Porter, J. W., and Porter, K. G.), CRC Press, Boca Raton, Florida, pp. 497-522.

Froede, C. R., 2002, Rhizolith evidence in support of a late Holocene sea-level highstand at least 0.5m higher than present at Key Biscayne, Florida: Geology, v. 30, p. 203-206.

Grimm, E. C., 1987, CONISS: a Fortran 77 program for stratigraphically constrained cluster analysis by the method of incremental sum of squares: Computers and Geoscience, v. 13, p. 13-25.

Halley, R. B., and Rouler, L. M., 1999, Reconstructing the history of eastern and central Florida Bay using mollusk-shell isotope records: Estuaries, v. 22, p. 358-368.

Hill, T., Brooks, G. R., Duncan, D. S., and Medioli, F. S., 2003, Benthic foraminifera of the Holocene transgressive west-central Florida inner shelf: paleoenvironmental implications: Marine Geology, v. 200, p. 263-272.

Holmes, C. W., Robbins, J., Halley, R., and Bothner, M., 2001, Sediment dynamics of Florida Bay mud banks on a decadal time scale: Bulletins of American Paleontology, v. 361 , p. 31-40. 
Huvane, J. K., and Cooper, S. R., 2001, Diatoms as indicators of environmental change in sediment cores from northeastern Florida Bay: Bulletins of American Paleontology, v. 361, p. 145-158.

Ishman, S. E., Graham, I., and Ambrosio, J., 1997, Modern benthic foraminifer distributions in Biscayne Bay: Analogs for historical reconstructions: U.S. Geological Survey Open-File Report 97-34. 20 pp.

Ishman, S. E., 2000, Benthic foraminiferal distributions in south Florida: Environmental Micropalenotology, v. 15, pp. 271-383.

Kelble, C. R., Johns, E. M., Nuttle, W. K., Lee, T. N., Smith, R. H., and Ortner, P. B., 2007, Salinity patterns of Florida Bay: Estuarine, Coastal and Shelf Science, v. 71, p. 318-334.

Lidz, B. H., and Rose, P. R., 1989, Diagnostic foraminiferal assemblages of Florida Bay and adjacent shallow waters: a comparison: Bulletin of Marine Sciences, v. 44, p. 399418.

Light, S. S., and Dineen, J. W., 1994, Water control in the Everglades: a historical perspective, in Everglades: The Ecosystem and Its Restoration, (eds. Davis, S. M., and Ogden, J. C.), St. Lucie Press, Delray Beach, Florida, pp. 47-84.

Lirman, D., and Cropper, W. P., 2003, The influence of salinity on seagrass growth, survivorship and distribution within Biscayne Bay, Florida: field, experimental, and modeling studies: Estuaries, v. 26, p. 131-141.

McIvor, C. C., Ley, J. A., and Bjork, R. D., 1994, Changes in freshwater inflow from the Everglades to Florida Bay, in Everglades: the ecosystem and its restoration, (eds. Davis, S. M., and Ogden, J. C.), St. Lucie Press, Delray Beach, Florida, pp. 117-146.

Montague, C. L., and Ley, J. A., 1993, A possible effect of salinity fluctuation on abundance of benthic vegetation and associated fauna in northeastern Florida Bay: Estuaries, v. 16, p. 703-717.

Murray, J. W., 1991, Ecology and Palaeoecology of Benthic Foraminifera, Published in collaboration with the Palaeontological Association, $397 \mathrm{pp}$.

Murray, J. W., 2000, When does environmental variability become environmental change? The proxy record of benthic foraminifera, in Environmental Micropaleontology: The Application of Microfossils to Environmental Geology, (eds. Martin, R. E.), Kluwer Academic Publishers, New York, USA, pp. 9-11. 
Nuttle, W. K., Fourqurean, J .W., Cosby, B. J., Zieman, J. C., and Robblee, M. B., 2000, Influence of net freshwater supply on salinity in Florida Bay: Water Resources Research, v. 36, P. 1805-1822.

Poag, W. C., 1978, Paired foraminiferal ecophenotypes in Gulf Coast estuaries: ecological and paleoecological implications: Transactions of the Gulf Coast Association of Geological Societies, v. 28, p. 395-421.

Poag, W. C., 1981, Ecologic Atlas of Benthic Foraminifera of the Gulf of Mexico: Woods Hole, Massachusetts, Marine Science International, 174 pp.

Phleger, F. B., 1954. Ecology of foraminifera and associated microorganisms from Mississippi Sound and environments: American Association of Petroleum Geologists, Bulletin, v. 39, p.584-647.

Phleger, F. B., 1955. Ecology of foraminifera in southeastern Mississippi Delta area: American Association of Petroleum Geologists, Bulletin, v. 39, p. 712-752.

Reinhardt, E. G., Fitton, R. J., and Schwarcz, H. P., 2003, Isotopic (Sr, O, C) indicators of salinity and taphonomy in marginal marine systems: Journal of Foraminiferal Research, v. 33, p. 262-272.

Rose, R. P., and Lidz, B. H., 1977, Diagnostic foraminiferal assemblages of shallow water modern environments: south Florida and the Bahamas: Sedimenta VI, 55 pp.

Schomer, N. S., and Drew, R. D., 1982, An ecological characteristization of the lower Everglades, Florida Bay and the Florida Keys: U.S. Fish Wildlife Survey Publication, FWS/OBS-82/58.

Sen Gupta, B. K., 1999, Foraminifera in marginal marine environments, in Modern Foraminifera, (eds. Sen Gupta, B. K.), Kluwer Academic Publishers, The Netherlands, $371 \mathrm{pp}$.

Sklar, F., McVoy, C., VanZee, R., Gawlik, D. E., Tarboton, K., Rudnick, D., and Miao, S., 2002, The effect of alterd hydrology on the ecology of the Everglades, in The Everglades, Florida Bay, and Coral Reefs of the Florida Keys: An Ecosystem Sourcebook, (eds. Porter, J. W., and Porter, K. G.), CRC Press, Boca Raton, Florida, pp. 39-82.

Stuiver, M., Reimer, P. J., Bard, E., Beck, J. W., Burr, G. S., Hughen, K. A., Kromer, B., McCormac, G., Van, D. P. J., Spurk, M., 1998, INTCAL98 radiocarbon age calibration, 24,000-0 cal B.P., Radiocarbon 40, v. 30, p. 1041-1083.

Swart, P. K., Dodge, R. E., and Hudson, H. J., 1996, A 240-year stable oxygen and carbon isotopic record in a coral from South Florida: Implications for the prediction of precipitation in southern Florida, Palaios, v. 11, p.362-375. 
Swart, P. K., Healy, G., Greer, L., Saied A., Anderegg, D., and Dodge, R. E., 1999, The use of proxy chemical records in coral skeletons to ascertain past environmental conditions in Florida Bay: Estuaries, v. 22, p. 384-397.

Talma, A. S., Vogel, J. C., 1993, A simplified approach to calibrating ${ }^{14} \mathrm{C}$ dates, Radiocarbon 35, v. 2, p. 317-322.

Wanless, H. R., and Tagett, M. G., 1989, Origin, growth and evolution of carbonate mudbanks in Florida Bay: Bulletin of Marine Science, v. 44, p. 454-489.

Wantland, K. F., 1967, Recent Foraminifera of the British Honduras Shelf: unpublished Ph.D. dissertation, Rice University, Houston, Texas, 125 pp. 
Table 3.1 Description of coring sites examined in this study. Cores were split into 2-cm samples.

\begin{tabular}{|l|l|l|l|l|}
\hline Site & $\begin{array}{l}\text { Latitude } \\
\text { (N) }\end{array}$ & $\begin{array}{l}\text { Longtitude } \\
(\mathbf{W})\end{array}$ & $\begin{array}{l}\text { Core } \\
\text { length }\end{array}$ & $\begin{array}{l}\text { Water } \\
\text { depth }\end{array}$ \\
\hline $\begin{array}{l}\text { Bob Allen } \\
\text { Bank Core } \\
\# 0206122\end{array}$ & $\begin{array}{l}25^{\circ} \\
01.670^{\prime}\end{array}$ & $80^{\circ} 40.871^{\prime}$ & $200 \mathrm{~cm}$ & $48 \mathrm{~cm}$ \\
\hline $\begin{array}{l}\text { Bob Allen } \\
\text { Bank Core } \\
\# 0206124\end{array}$ & $\begin{array}{l}25^{\circ} \\
01.731^{\prime}\end{array}$ & $80^{\circ} 40.795^{\prime}$ & $194 \mathrm{~cm}$ & $48 \mathrm{~cm}$ \\
\hline $\begin{array}{l}\text { Russell Key } \\
\text { Core \#0206125 }\end{array}$ & $\begin{array}{l}25^{\circ} \\
03.871^{\prime}\end{array}$ & $80^{\circ} 37.501^{\prime}$ & $170 \mathrm{~cm}$ & $46 \mathrm{~cm}$ \\
\hline $\begin{array}{l}\text { Russell Key } \\
\text { Core \#0206127 }\end{array}$ & $\begin{array}{l}25^{\circ} \\
03.851^{\prime}\end{array}$ & $80^{\circ} 37.371^{\prime}$ & $170 \mathrm{~cm}$ & $46 \mathrm{~cm}$ \\
\hline $\begin{array}{l}\text { Ninemile Bank } \\
\text { Core \#0208134 }\end{array}$ & $\begin{array}{l}24^{\circ} \\
57.128^{\prime}\end{array}$ & $80^{\circ} 53.607^{\prime}$ & $244 \mathrm{~cm}$ & $37 \mathrm{~cm}$ \\
\hline $\begin{array}{l}\text { Trout Cove } \\
\text { Core \#02061211 }\end{array}$ & $\begin{array}{l}25^{\circ} \\
12.582^{\prime}\end{array}$ & $80^{\circ} 31.932^{\prime}$ & $96 \mathrm{~cm}$ & $47 \mathrm{~cm}$ \\
\hline
\end{tabular}


Table 3.2 Radiocarbon dates for Ninemile Bank obtained by L. Collins from Beta Analytic Laboratory, Miami, Florida. Ages were corrected for ${ }^{13} \mathrm{C} /{ }^{12} \mathrm{C}$, and global and local geographic reservoir effects (Talma and Vogel, 1993) prior to the calibration $\left({ }^{13} \mathrm{C} /{ }^{12} \mathrm{C}=1.6\right.$; local reservoir effect $=-5 \pm 20$; global reservoir effect $=-200$ to 500$)$. The database of Marine 98 (Stuiver et al., 1998) was used for calibration.

\begin{tabular}{|c|c|c|c|c|c|}
\hline $\begin{array}{l}\text { Core } \\
\text { location }\end{array}$ & $\begin{array}{l}\text { Core } \\
\text { depth } \\
(\mathrm{cm})\end{array}$ & $\begin{array}{l}\text { Type of } \\
\text { material dated }\end{array}$ & $\begin{array}{l}\text { Measured } \\
\text { radiocarbon } \\
\text { age (B.P.) }\end{array}$ & $\begin{array}{l}\text { Conventional } \\
\text { radiocarbon } \\
\text { age (B.P.) }\end{array}$ & $\begin{array}{l}\text { Two sigma age } \\
\text { range (Cal. Years } \\
\text { B.P.) }\end{array}$ \\
\hline \multirow[t]{5}{*}{$\begin{array}{l}\text { Ninemile } \\
\text { Bank }\end{array}$} & $\begin{array}{l}120- \\
122\end{array}$ & Brachiodontes & $2340 \pm 40$ & $2750 \pm 40$ & $2660 \sim 2340$ \\
\hline & $\begin{array}{l}152- \\
154\end{array}$ & Brachiodontes & $2800 \pm 40$ & $3210 \pm 40$ & $3150 \sim 2920$ \\
\hline & $\begin{array}{l}178- \\
180\end{array}$ & $\begin{array}{l}30.5-\mathrm{cm} \\
\text { bivalves and } 1 \\
\text { Brachiodontes } \\
\text { fragment }\end{array}$ & $3030 \pm 40$ & $3400 \pm 40$ & $3360 \sim 3200$ \\
\hline & $\begin{array}{l}208- \\
210\end{array}$ & $\begin{array}{l}10.5-\mathrm{cm} \\
\text { broken } \\
\text { gastropod }\end{array}$ & $3210 \pm 40$ & $3590 \pm 40$ & $3580 \sim 3390$ \\
\hline & $\begin{array}{l}228- \\
230\end{array}$ & $\begin{array}{l}2 \text { gastropod } \\
\text { fragments, } 1 \\
\text { topshell and } 1 \\
\text { olive shell }\end{array}$ & $3320 \pm 40$ & $3720 \pm 40$ & $3800 \sim 3530$ \\
\hline
\end{tabular}


Table 3.3 Benthic faunal assemblages and their component species, with salinity ranges for the assemblages (Lidz and Rose, 1989; Murray, 1991).

\begin{tabular}{|l|l|}
\hline \multicolumn{1}{|c|}{ Brackish Fauna } & \multicolumn{1}{|c|}{ Marine Fauna } \\
\hline Ammonia beccarii & Archaias angulatus; Articulina mucronata; \\
Elphidium galvenstonense & Biloculina eburnea; Heterillina cribrostoma; \\
Elphidium poeyanum & Miliolinella labiosa; Pyrgo elongata; Q. akneriana; \\
Elphidium mexicanum & Q. angulatus; Q. agglutinans; Q. bosciana; Q. bicornis; \\
Ammobaculites exiguus & Q. bidentata; Q. impressa; Q. laevigata; Q. lamarckiana; \\
& Q. polygona; Q. poeyana; Q. seminulum; Q. subpoeyana; \\
& Triloculina linneiana; T. fitterei; T. rotunda; \\
& Paeteoris dilatata; Peneroplis proteus \\
& \\
\hline
\end{tabular}


Table 3.4 Time intervals defined by land-use activities and documented environmental changes (Light and Dineen, 1994; Fourqurean and Robblee, 1999; Sklar et al, 2002). These intervals are used in the ANOVAs.

\begin{tabular}{|l|l|l|}
\hline $\begin{array}{l}\text { Interval } \\
\text { Number }\end{array}$ & Event & Time \\
\hline Interval 1 & Pre-anthropogenic activity & $1880-1904$ \\
\hline Interval 2 & $\begin{array}{l}\text { Construction of: Flagler Railroad between 1905 and } \\
1912 ; \text { four major canals between 1907 and 1917; } \\
\text { Tamiami Trail between 1915 and 1928; major } \\
\text { hurricanes at 1926, 1928, 1935 }\end{array}$ & $1905-1936$ \\
\hline Interval 3 & $\begin{array}{l}\text { Multiyear droughts in early 1940s and mid-1950s; } \\
\text { construction of more canals and levees; construction } \\
\text { of several leeves between 1954 and 1959 completed } \\
\text { partitioning off 283,000 ha of deep muck lands } \\
\text { known as Everglades agricultural areas }\end{array}$ & $1937-1959$ \\
\hline Interval 4 & $\begin{array}{l}\text { Construction of Water Retention Areas between } \\
\text { 1960 and 1963; extension of more canals, and a } \\
\text { series of water management plans }\end{array}$ & $1960-1984$ \\
\hline Interval 5 & $\begin{array}{l}\text { South Florida Water Management District water } \\
\text { supply plan; multiyear drought during the end of the } \\
1980 \text { s }\end{array}$ & $1985-1992$ \\
\hline Interval 6 & Modern precipitation & $1993-2001$ \\
\hline
\end{tabular}




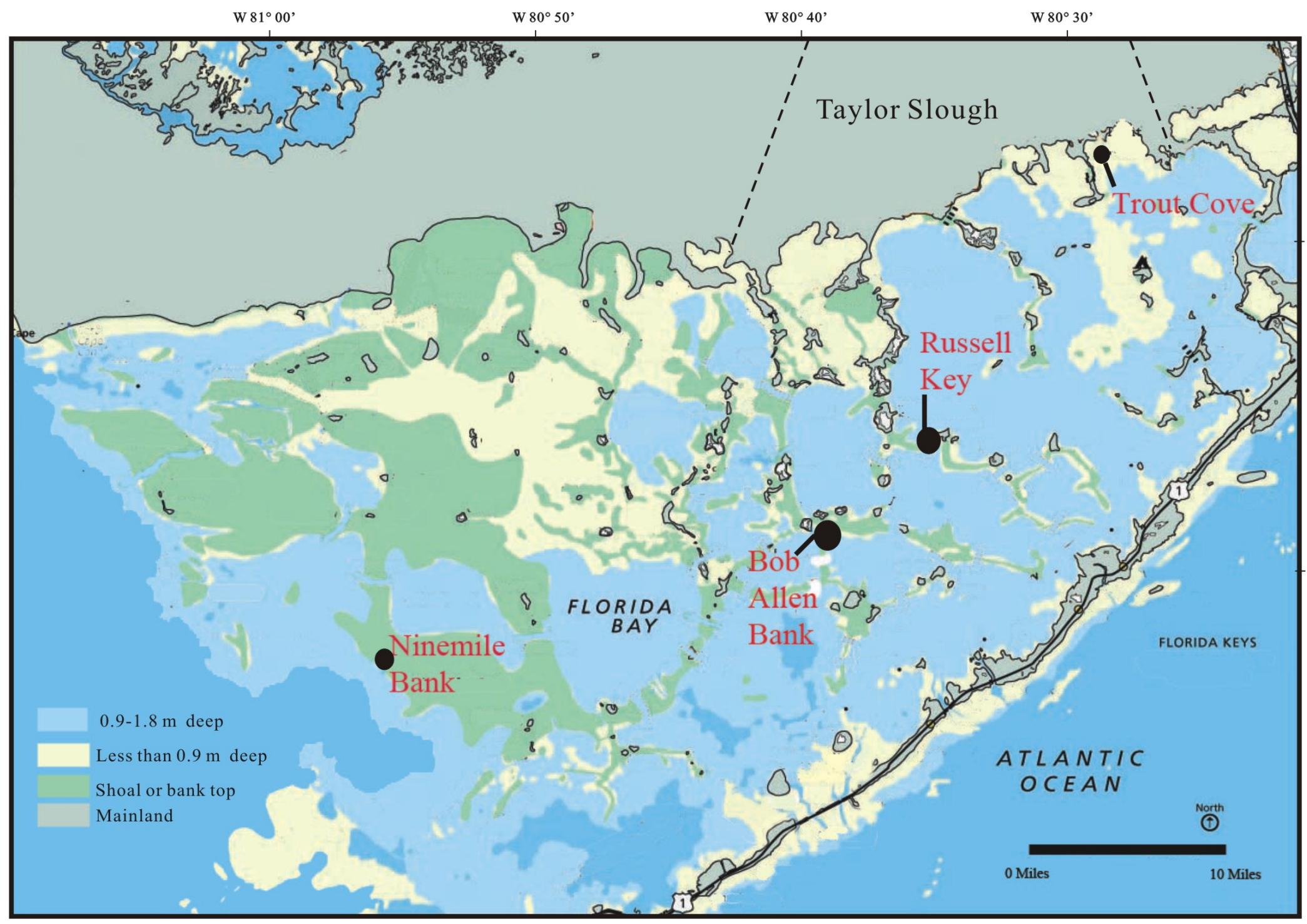

Figure 3.1 Map of Florida Bay showing the four coring sites: Ninemile Bank, Bob Allen Bank, Russell Key and Trout Cove. 


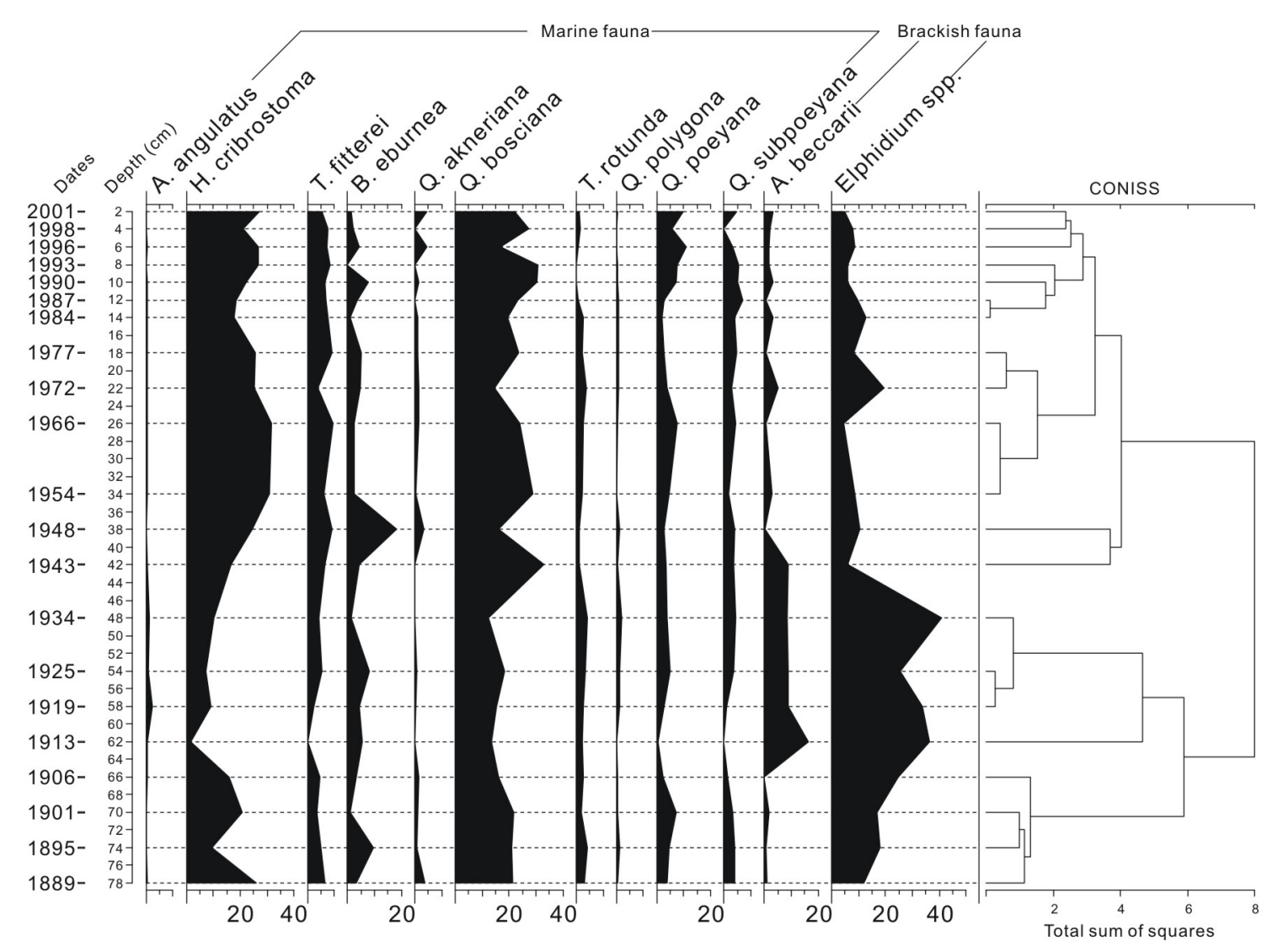

Figure 3.2 Percentages of most abundant benthic foraminifera in Bob Allen Bank Core $\# 0206122$. 


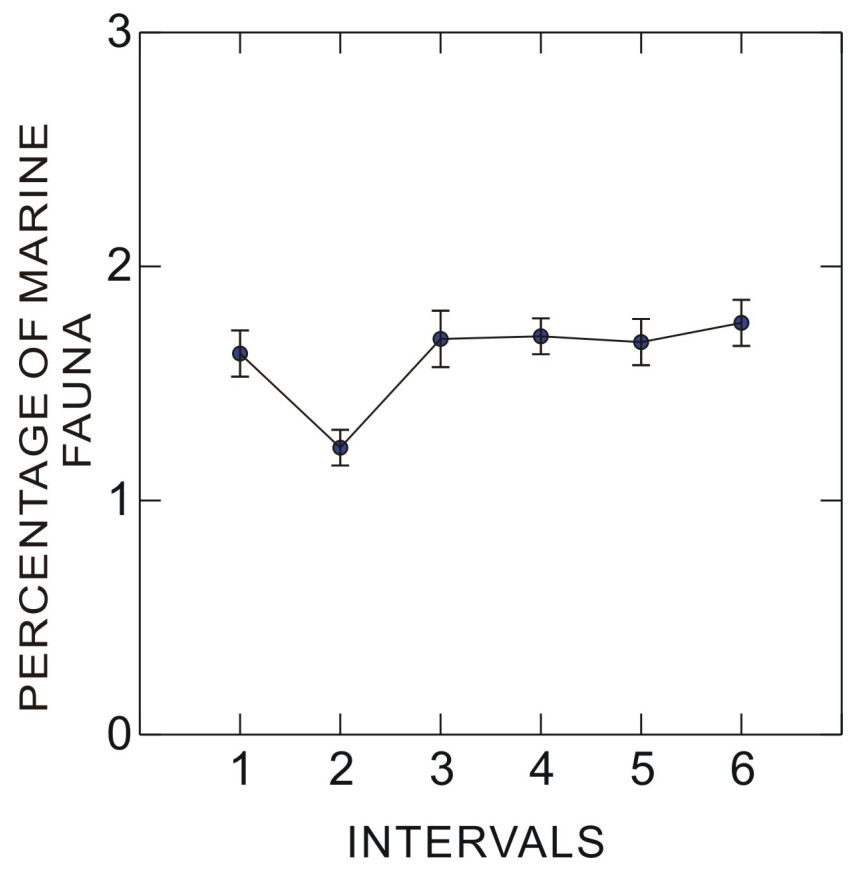

Figure 3.3 ANOVA for Bob Allen Bank Core \#0206122. Intervals are defined in Table 3.4. 


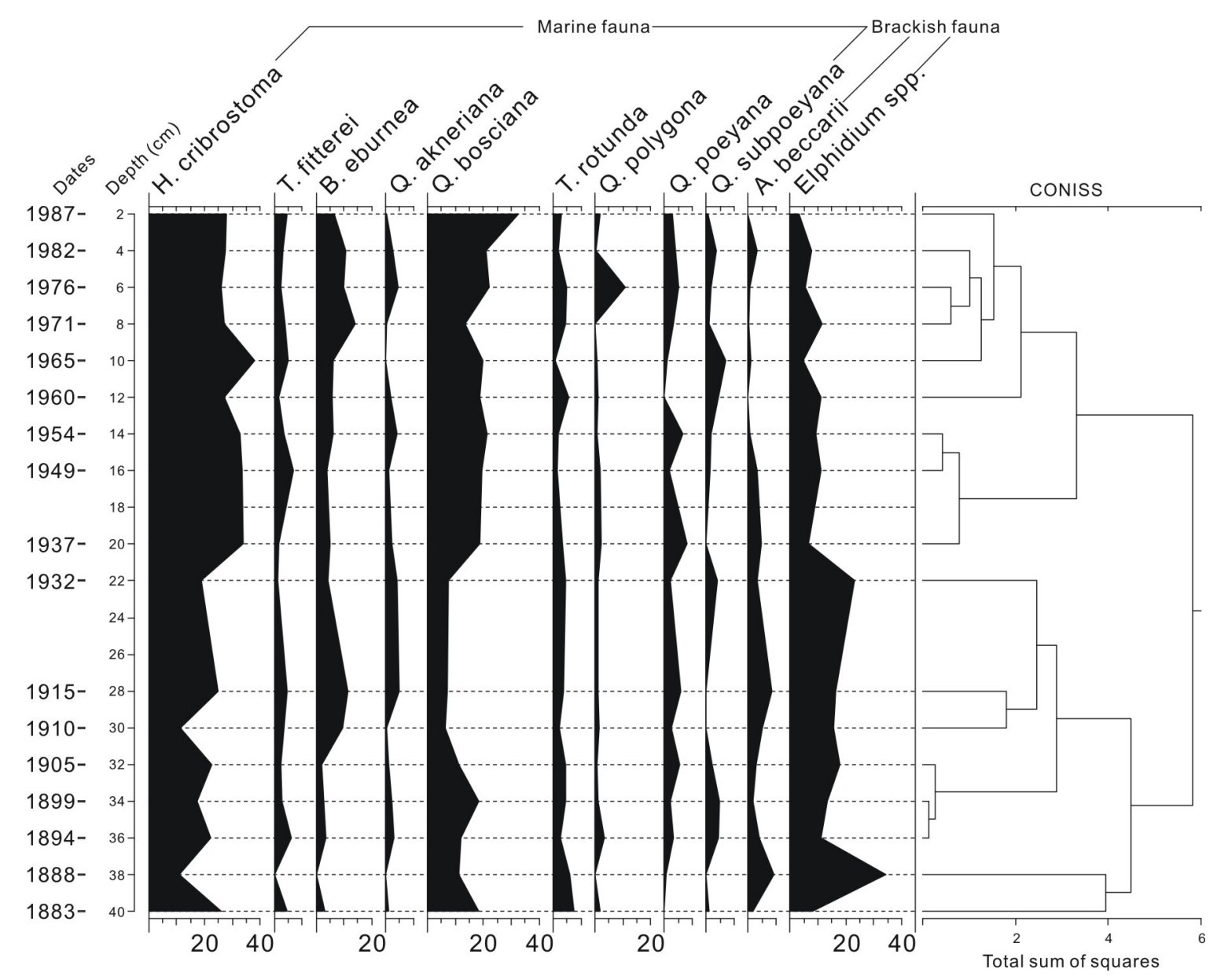

Figure 3.4 Percentages of the most abundant benthic foraminifera in Bob Allen Bank Core \#0206124. 


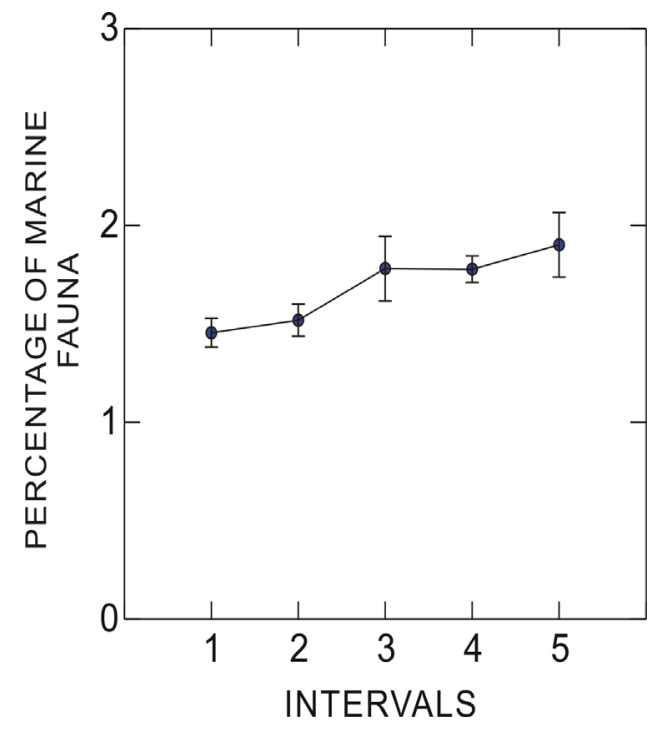

Figure 3.5 ANOVA for Bob Allen Bank Core \#0206124. Intervals are defined in Table 3.4. 

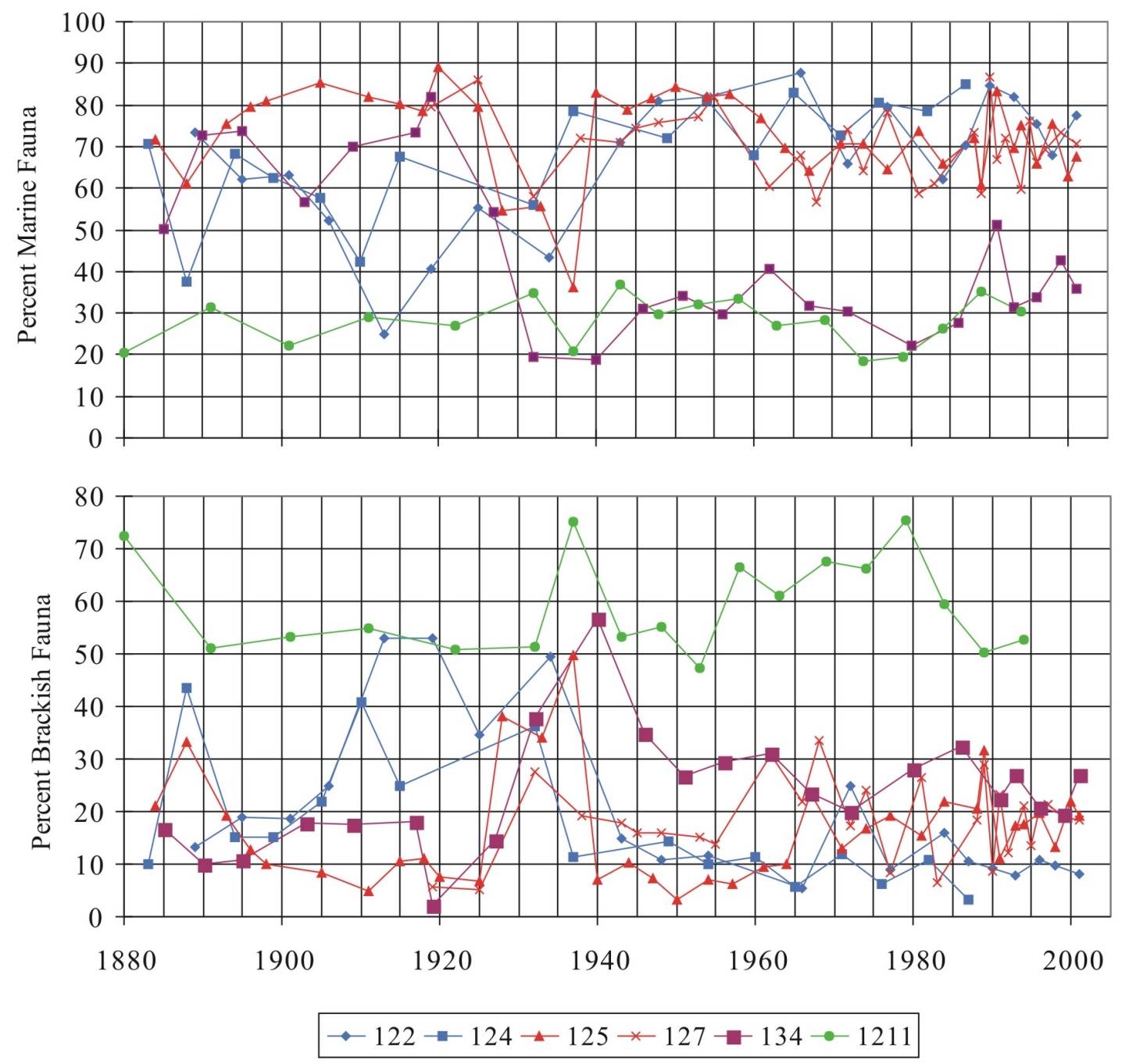

Figure 3.6 Percentages of the marine and brackish faunas (defined in Table 3.3) in the cores from Bob Allen Bank (122, 124), Russell Key $(125,127)$, Ninemile Bank (134) and Trout Cove (1211), last 120 years. 


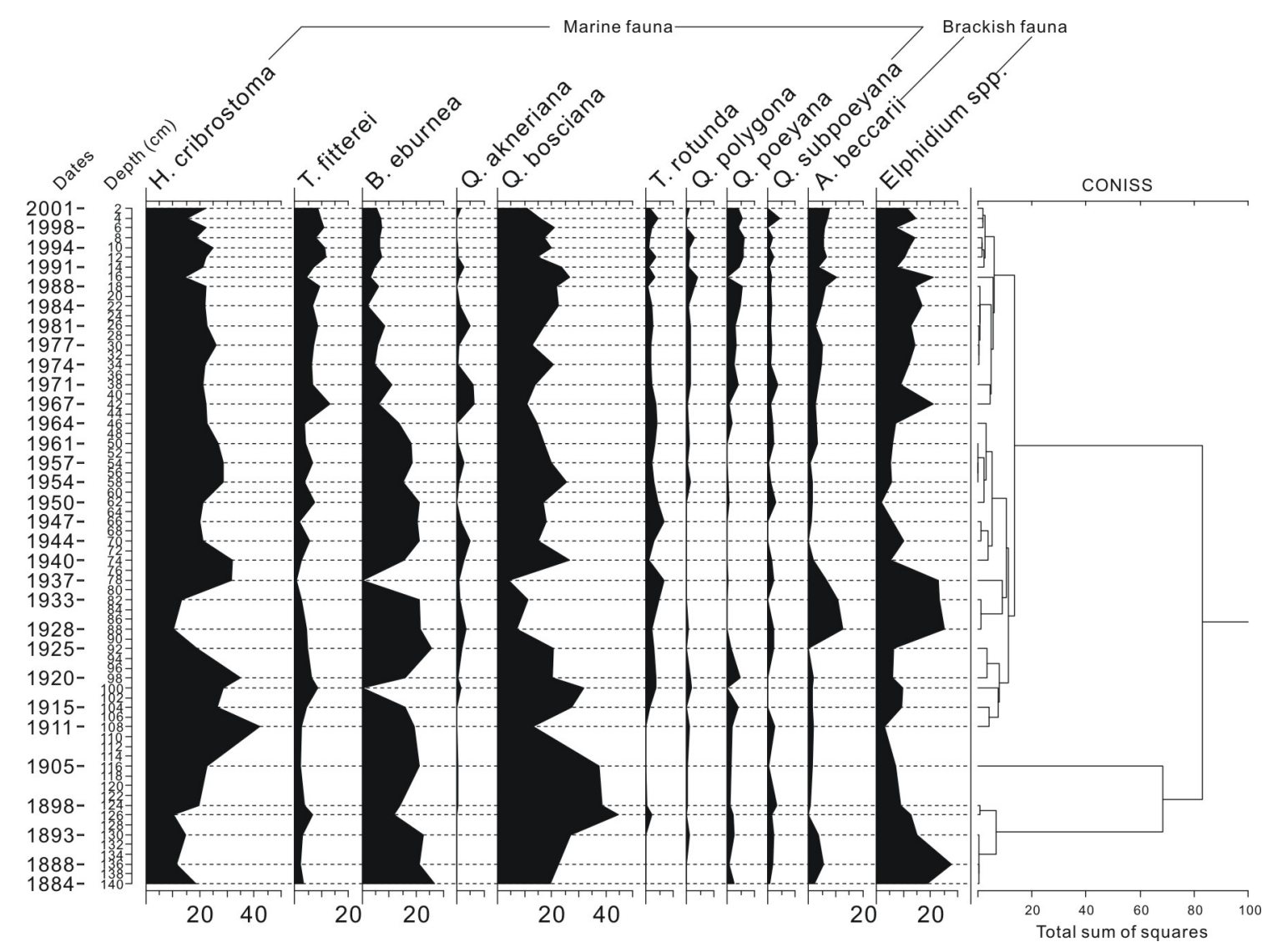

Figure 3.7 Percentages of the most abundant benthic foraminifera in Russell Key Core \#0206125. 


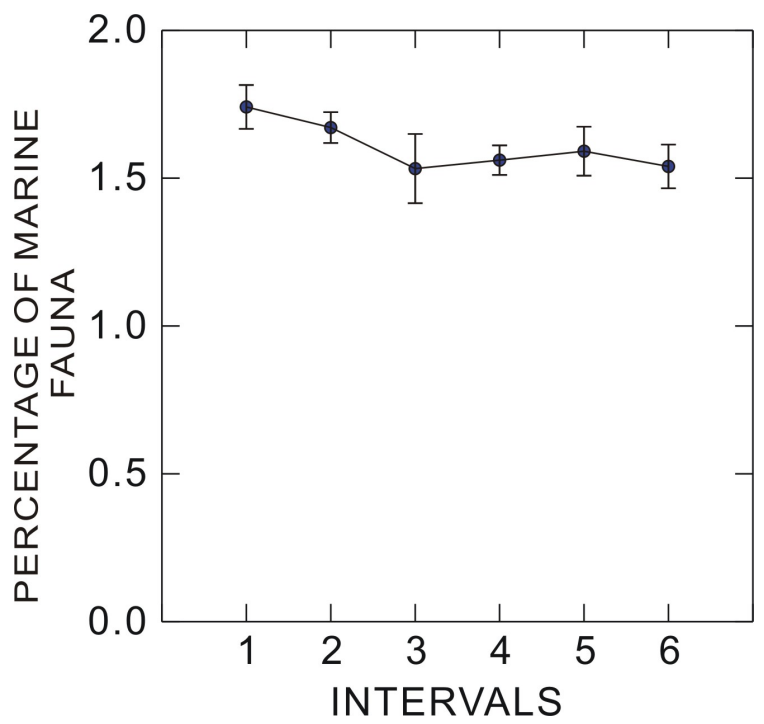

Figure 3.8 ANOVA for Russell Key Core \#0206125. Intervals are defined in Table 3.4. 


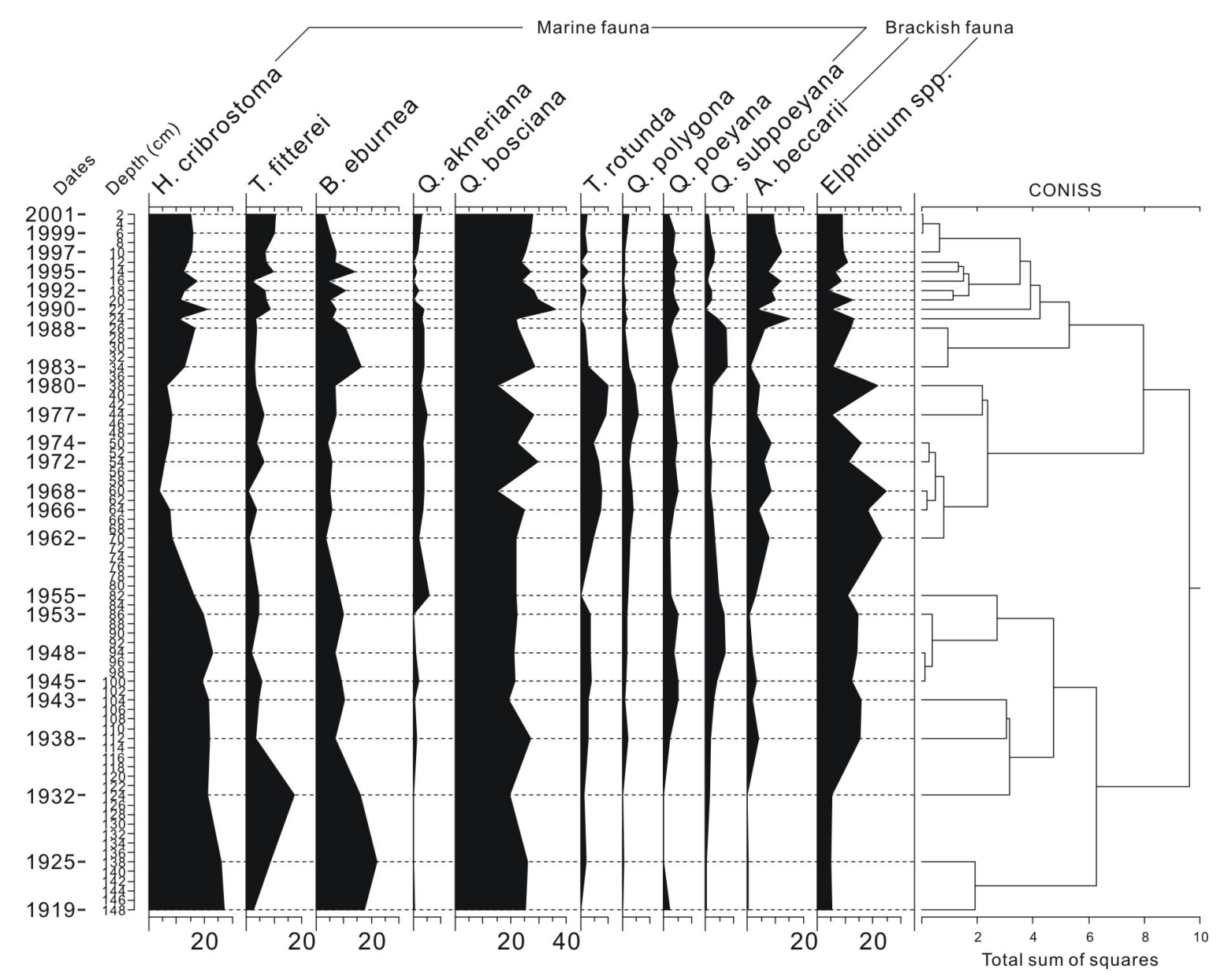

Figure 3.9 Percentages of the most abundant benthic foraminifera in Russell Key Core \#0206127. 


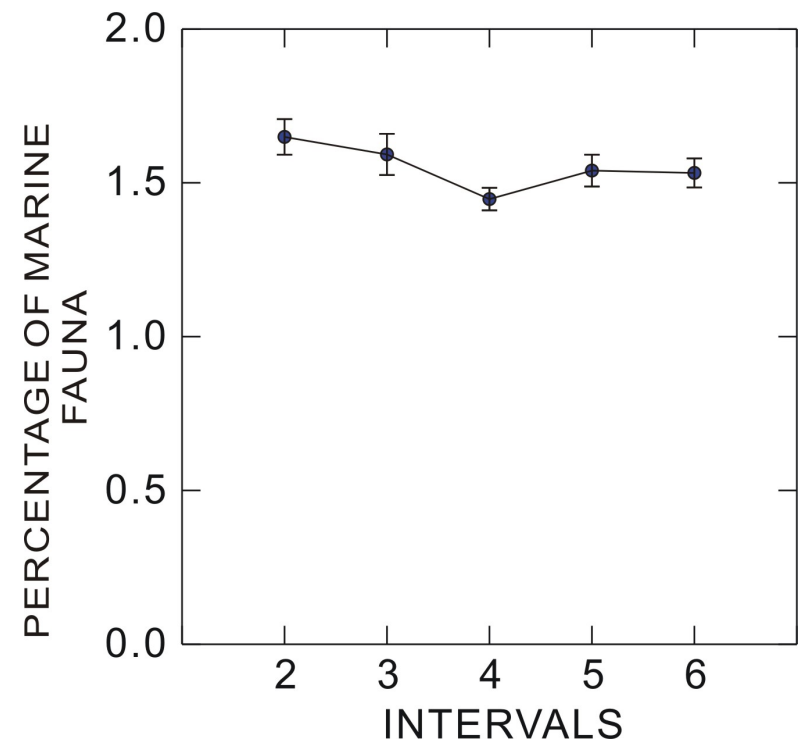

Figure 3.10 ANOVA for Russell Key Core \#0206127. Intervals are defined in Table 3.4. 


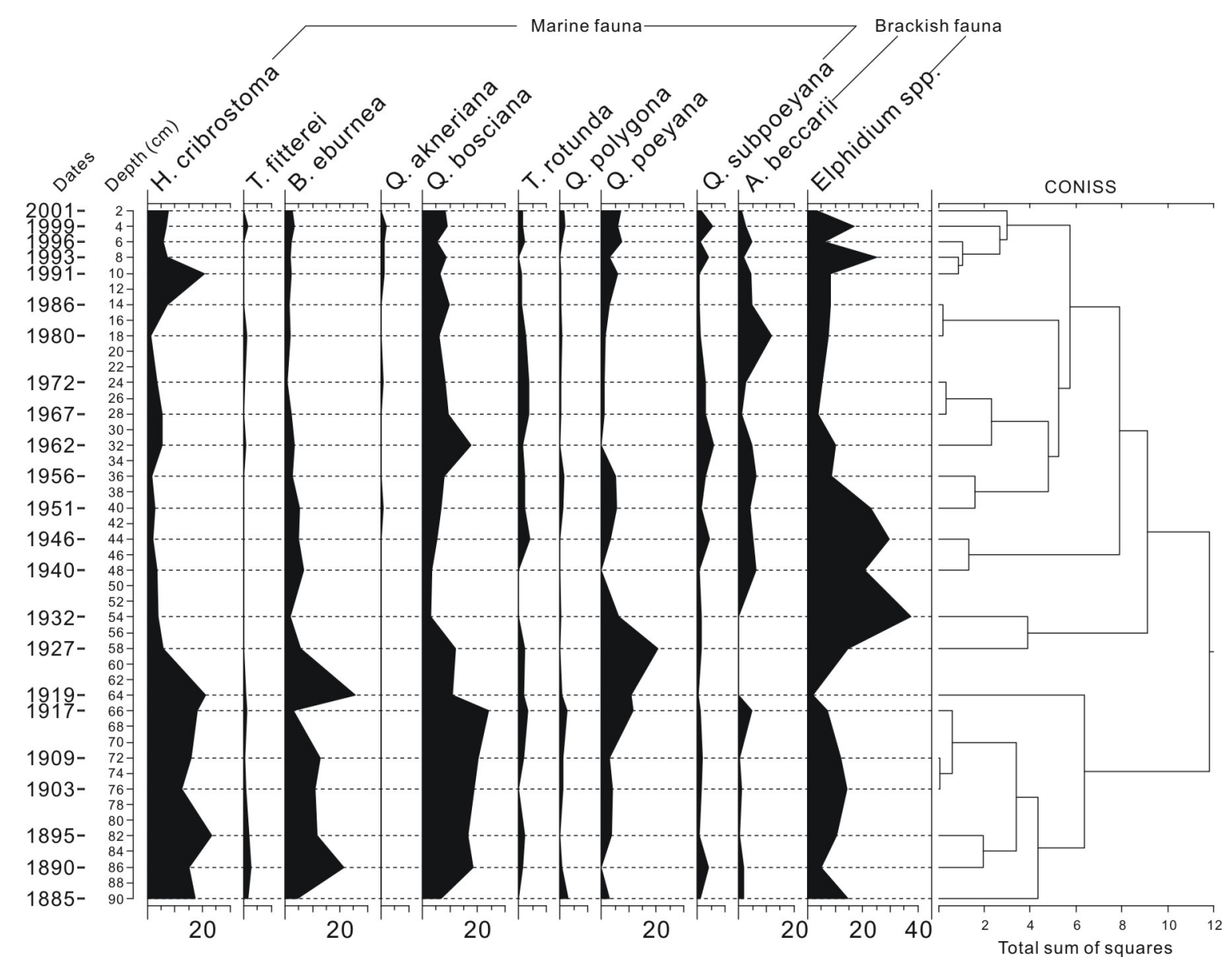

Figure 3.11 Percentages of the most abundant benthic foraminifera in Ninemile Bank Core \#0208134. 


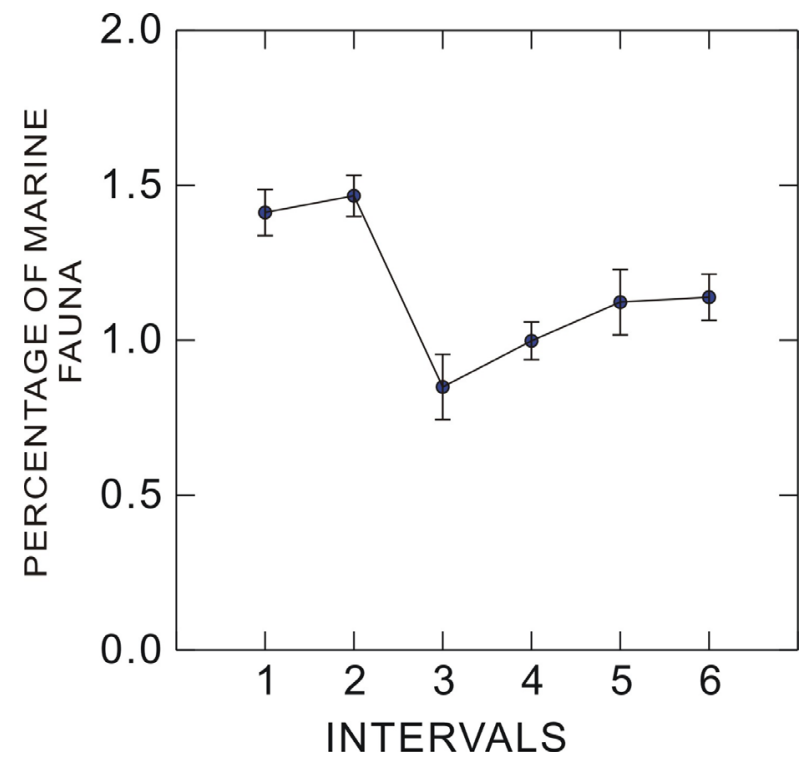

Figure 3.12 ANOVA for Ninemile Bank Core \#0208134. Intervals are defined in Table 3.4 . 


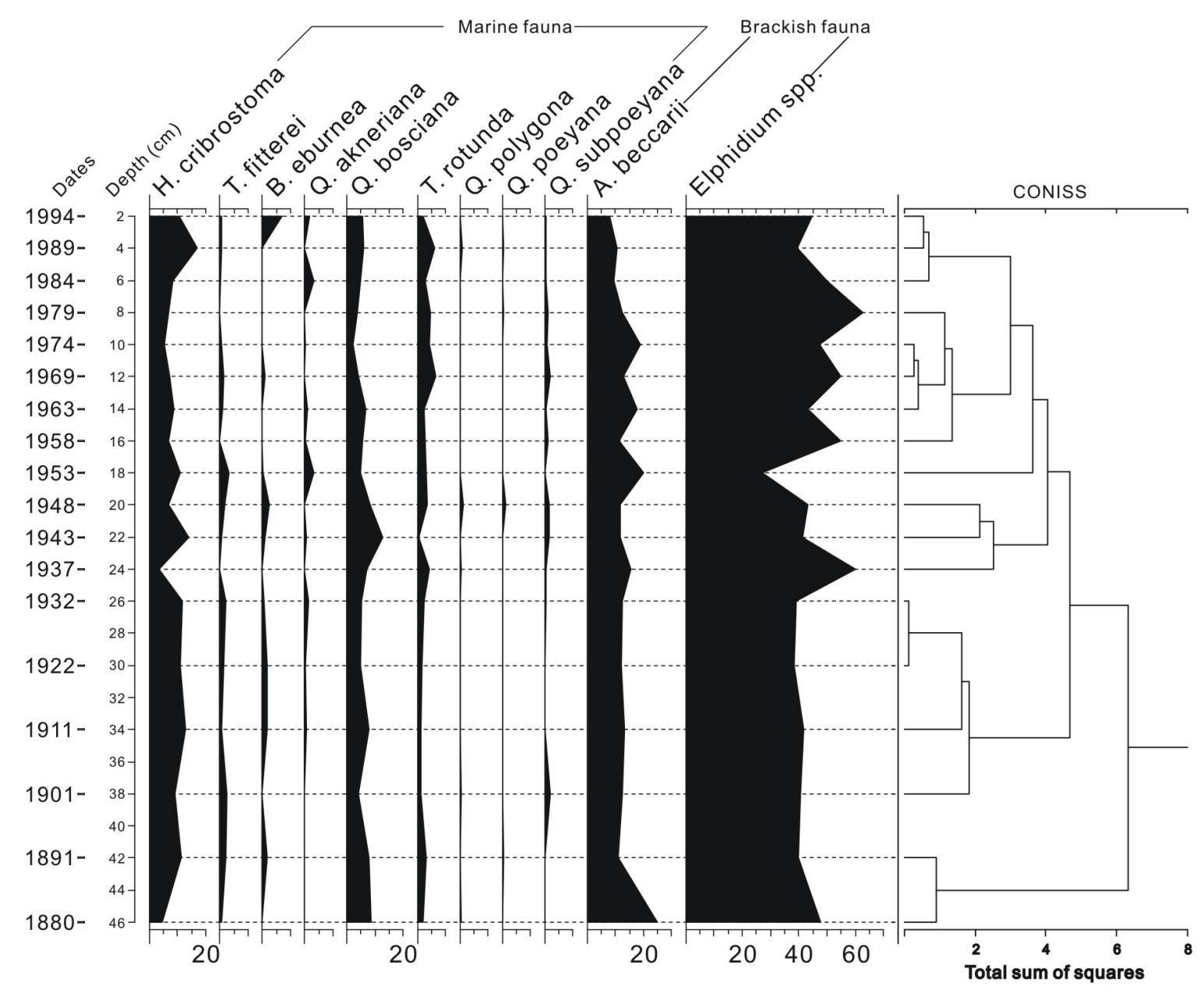

Figure 3.13 Percentages of the most abundant benthic foraminifera in Trout Cove Core \#02061211. 


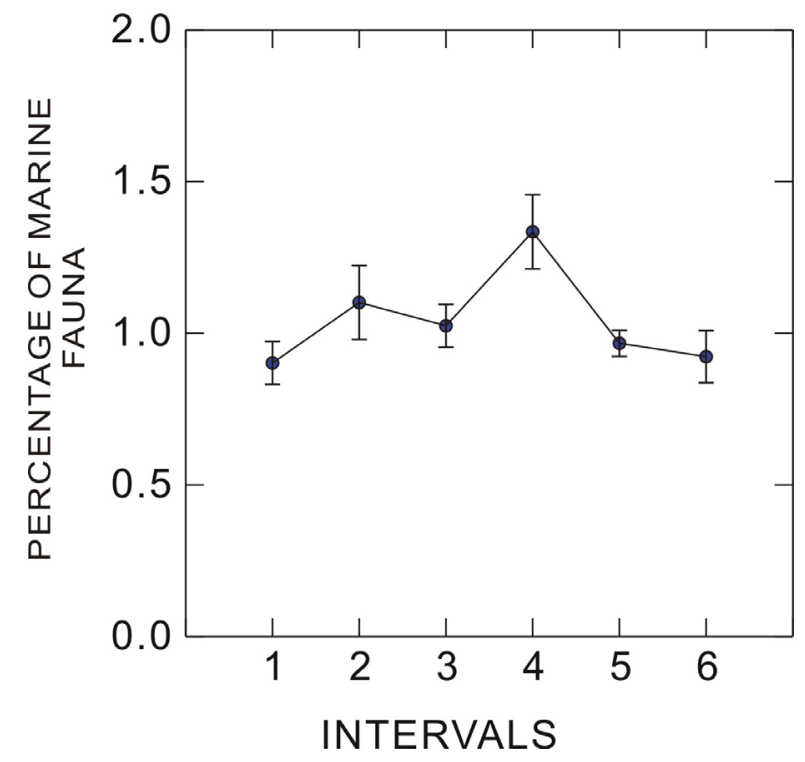

Figure 3.14 ANOVA for Trout Cove Core \#02061211. Intervals are defined in Table 3.4. 


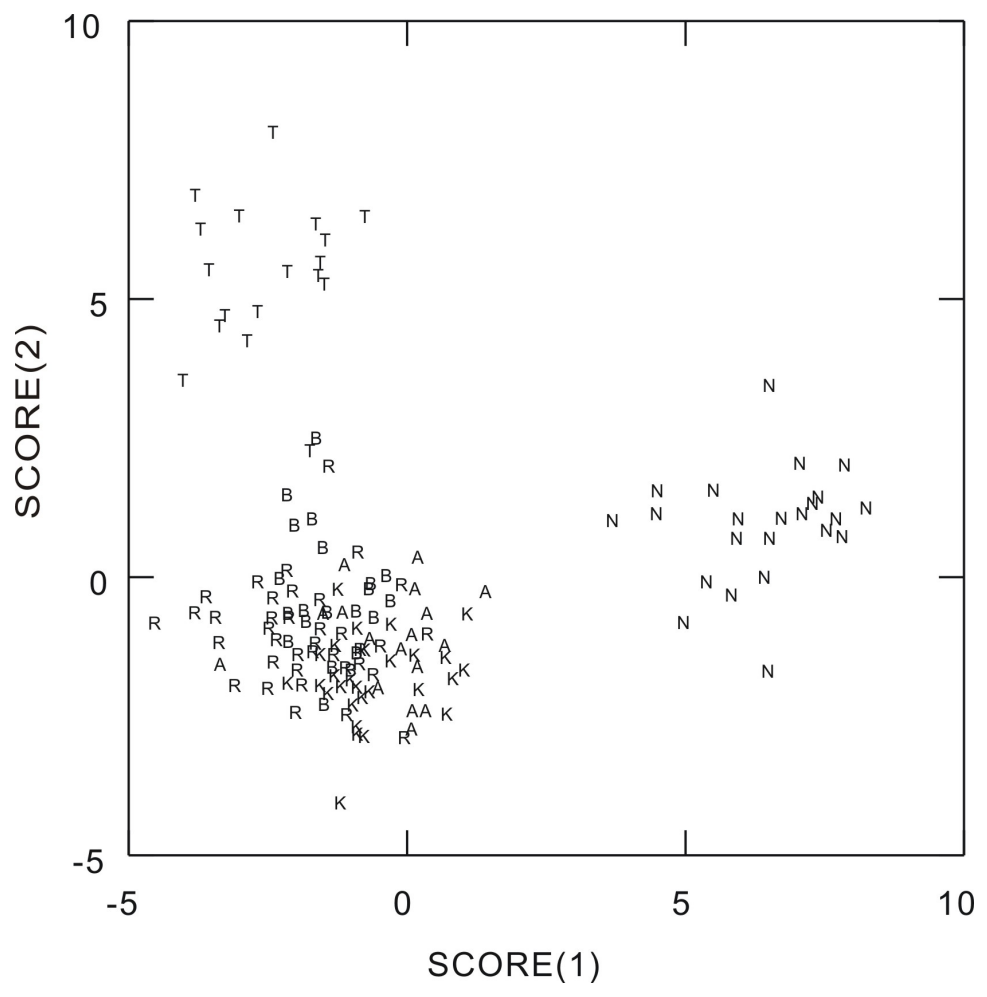

Figure 3.15 Discriminant analysis of samples from the four areas: B, A-Bob Allen Bank; R, K-Russell Key; T-Trout Cove; N-Ninemile Bank. 


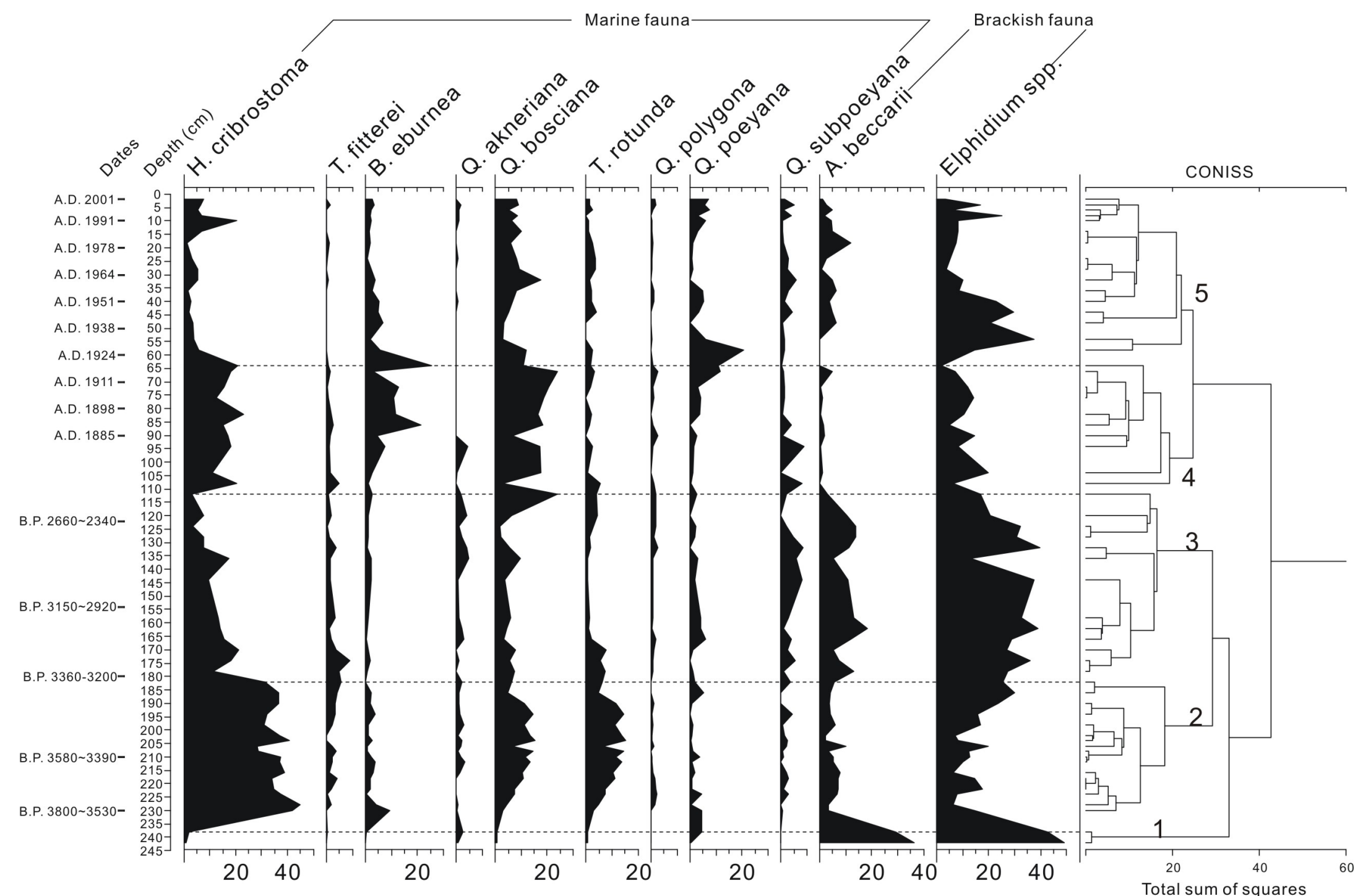

Figure 3.16 Percentages of the most abundant brackish and marine taxa in Ninemile Bank Core \#0208134. 


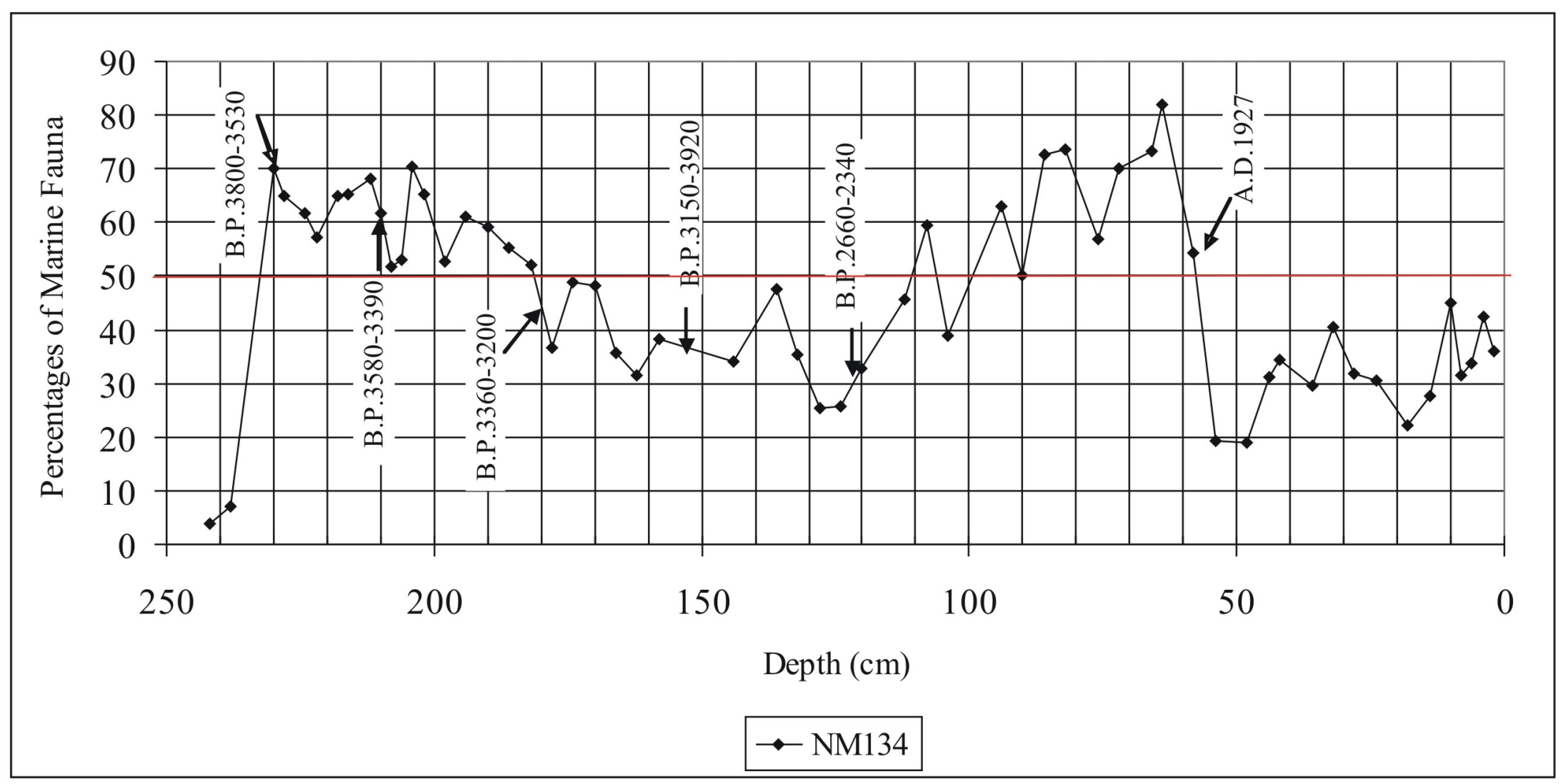

Figure 3.17 Percentages of marine fauna in Ninemile Bank core over the last $\sim 4,000$ years $(0-242 \mathrm{~cm})$. 


\section{CHAPTER 4}

\section{PALEOECOLOGY OF FLORIDA BAY}

\section{Introduction}

The habitats of Florida Bay have been changing since its initial flooding 4000 years ago. The sequence of change proceeded through a freshwater and Everglades-like environment, to a mangrove swamp, and finally a shallow bay (Davies and Cohen, 1989). Sedimentologic evidence indicates that with the rise of sea level, eastern Florida Bay was gradually inundated until about 1500 years ago when it became fully marine (Wanless and Tagett, 1989). As a result of continuing changes in sea level and other environmental factors, the habitats of Florida Bay have been altered through time. In this study, habitat changes are studied by analyzing the sedimentary record of benthic foraminiferal assemblages, which respond to changes in conditions such as salinity, substratum type, temperature and food. The results from six sediment cores taken in Florida Bay are applied to an analysis of paleoecology, including sea level change, over the past 4000 years.

The history of sea level rise has been investigated with changes in the lithology of sediments and in biological proxies. Freshwater mangrove peat has been found overlying the limestone at the base of the sediments in much of the bay, which supports the sea level rise. Wanless et al. (1994) described a rise in sea level of about $4 \mathrm{~cm} / 100$ years during the last 3200 years. Two different curves of sea-level rise through the late Holocene were proposed by Shepard (1963) and Fairbridge (1974). Shepard (1963) suggested that sea level was below the present sea level of 6000 years ago but rose with a 
gradually decreasing rate after that time. Studies focusing on mangrove peat deposits (Scholl et al., 1969; Gleason and Stone, 1994) and coral reefs in southwest Florida (Robbin, 1984) supported Shepard's hypothesis. Fairbridge (1976) proposed that there were four major transgressions and regressions over the past 6000 years and that sea level was even higher than at present during the time when major transgressions happened. This hypothesis was supported by the results of Missimer (1980, Gulf of Mexico), Stapor et al. (1987, 1991; southwest Florida), Walker et al. (1995, Gulf Coast of Florida) and Froede (2002, southeast Florida). The Florida carbonate platform is viewed as a good place to study sea level fluctuation because it has been tectonically stable for the past tens of thousands of years (Gleason and Stone, 1994). One purpose of this study is to test these hypotheses by examining the record of habitat changes over the last 4000 years. Biological proxies such as corals (Robbin, 1984; Toscano and Lundberg, 1998) and benthic foraminifera (Cann et al., 2002; Hill et al., 2003; Horton et al., 2003, 2005; Barbosa, 2005; Scott et al., 2000; Woodroff et al., 2005) have been used to study sea level variation. Many species of benthic foraminifera are restricted to certain water depths, so changes in assemblages through time can indicate sea level change. Several taxa of reef corals grow only to just below the level of mean low tide (Fairbridge, 1974).

Generally, two ecological types of benthic foraminiferal assemblages have been used to reconstruct past sea level fluctuations: salt marsh foraminifera and mangrove swamp foraminifera (Sen Gupta, 1999). Marsh foraminifera, in particular, are relatively accurate sea level indicators since they have narrow ecological tolerances and narrow vertical ranges in the intertidal zone (Woodroffe et al., 2005). Scott et al. (2001) identified the limits and ranges of several foraminiferal zones in salt marshes. A group of widespread 
agglutinated taxa including Ammotium, Miliammina, Trochammina, Arenoparrella and Tipotrocha (Sen Gupta, 1999) is generally regarded as typical of coastal salt marshes. Most of these well-known marsh foraminifera also occur in mangrove swamps, which are the tropical-subtropical ecological equivalent of temperate salt marshes. Ammotium and Arenoparrella, in particular, dominate mangrove assemblages in areas such as Trinidad (Saunders, 1958) and Florida (Brewster-Wingard and Ishman, 1999). Moreover, there is often a remarkable similarity between mangrove foraminiferal assemblages from very different longitudes (Sen Gupta, 1999). Therefore, foraminiferal studies focusing on mangrove swamps and salt marshes in other warm temperate to tropical locations (Halfar and Ingle, 2003; Barbosa et al., 2005; Vance et al., 2006) are compared to the assemblages in this study. Besides agglutinated species, calcareous perforate species such as Ammonia and Elphidium may constitute up to $80 \%$ of the total population in mangrove swamps (Rose and Lidz, 1977; Lidz and Rose, 1989). Furthermore, larger (calcareous imperforate) foraminifera like soritids are sparse or completely absent, and of the miliolids, only small amounts of Quinqueloculina, Miliolinella and Triloculina are occasionally present (usually less than $10 \%$; Lidz and Rose, 1989), probably due to the general brackish conditions of mangrove swamps. According to a recent study on modern mangrove swamps of Florida Bay, salinity varies from a median value of $7 \mathrm{psu}$ in the inner mangrove fringe to $15 \mathrm{psu}$ in the outer mangrove fringe (Boyer and Fourqurean, 1997). 


\section{Methods}

\section{Coring Sites and Sampling}

Eight sediment cores were collected by the U.S. Geological Survey with a piston-coring device at Bob Allen Bank, Ninemile Bank, Trout Cove and Russell Key in Florida Bay (Figure 4.1, Table 4.1). Two cores (around $100 \mathrm{~m}$ apart) were taken from each site. These sites were selected because they receive different sources of freshwater runoff and seawater. Trout Cove is close to the mainland and is more likely to be affected by the freshwater runoff; Ninemile Bank is furthest from the mainland and the Florida Keys, so it is projected to be minimally affected by human activity, and it is mostly influenced by the Gulf of Mexico; and Bob Allen Bank and Russell Key are located in the central bay and are hypothesized to be more affected by processes on both the mainland and the Keys. All cores were taken through calcareous muds to the limestone substratum and had an average length of $1.5 \mathrm{~m}$. Of these four sites, two (Bob Allen and Ninemile Bank) contained peat at the base. In order to determine the presence of laminations and to evaluate the extent of mixing, each core was x-rayed before sampling. All cores were well bioturbated with few laminations visible. Of these eight cores, only six (two cores each from Bob Allen Bank and Russell Key, and one each from Ninemile Bank and Trout Cove) were analyzed in the study because of time constraints. The details of the selection of the four sites are as follows:

1) Ninemile Bank has a sedimentary record of over 4000 years (Enos, $1989 ;{ }^{14} \mathrm{C}$ ages of this project). Of the four sites, Ninemile Bank has the longest core, and with the basal peat that typically marks the most terrestrially influenced facies (Enos, 1989). It potentially has the most complete record of habitat change. 
2) Bob Allen Bank is near the center of Florida Bay, which might be expected to have more intra- and inter-annual variation in environmental conditions than Ninemile Bank. Russell Key, also in central Florida Bay, is a few hundred meters across and about $1 \mathrm{~km}$ long (Cronin et al., 2001). Russell Key accreted in a southward direction (Wanless and Tagett, 1989), and lies much closer to the Everglades mainland than do Bob Allen Bank and Ninemile Bank. Since both Bob Allen Bank and Russell Key are strategically situated in the central part of Florida Bay, they may both have been affected by anthropogenic activities in the Everglades and Florida Keys.

3) The sampling site near Trout Cove is located near mainland mangroves in the northeastern bay, so it is more likely to have been affected by changes in freshwater runoff from the Everglades. Therefore, habitat changes may be more distinctive in this core.

The cores were sliced completely into 2-cm-thick samples, which were divided among researchers for anlysis. Each sample was divided into several parts for different research groups: $1 / 2$ was used to determine ages, $1 / 4$ was reserved for nutrient and stable isotope studies, $1 / 8$ was used for diatom research, and 1/8 was for foraminiferal research (this study).

\section{Age Determinations}

The method of ${ }^{210} \mathrm{~Pb}$ dating, based on the escape of radon gas from the earth, has been used primarily on lake sediments within the time range of $1-150$ years. This method is based on the radioactive disequilibrium between ${ }^{210} \mathrm{~Pb}$ and its parent, ${ }^{226} \mathrm{Ra}$ (Holmes et al., 
2001), and assumes that the radium distribution is constant and equal to the value where the total ${ }^{210} \mathrm{~Pb}$ activity is constant with depth.

The ${ }^{210} \mathrm{~Pb}$ method of age determination was described by Holmes et al. (2001), who ran the analyses at the U.S. Geological Survey, St. Petersburg, Florida, for this project and contributed ages based on a model for each core. Of the two models that have usually been used to calculate the age, the constant rate of supply model and the constant initial concentration model, the first model is used in this study. The constant rate of supply model assumes that the flux of ${ }^{210} \mathrm{~Pb}$ is constant over time regardless of how the sediment flux might vary, while the constant initial concentration model assumes that the concentration of ${ }^{210} \mathrm{~Pb}$ at time zero (when the sediment was deposited) has been constant over time.

The limitations of ${ }^{210} \mathrm{~Pb}$ dating preclude precise inter-site comparisons of interannual trends, especially during the periods in the late $19^{\text {th }}$ to early $20^{\text {th }}$ centuries when the precision of ${ }^{210} \mathrm{~Pb}$ dating is diminished. Therefore, for this project, only periods between 1880 and 2001 (a span of $\sim 120$ years - the outside limit of this method) are considered.

Materials measured by the radiometric technique were analyzed by synthesizing sample carbon to benzene $(92 \% \mathrm{C})$, measuring for ${ }^{14} \mathrm{C}$ content in one of 53 scintillation spectrometers, and then calculating for radiocarbon age. Marine carbonate samples were corrected for ${ }^{13} \mathrm{C} /{ }^{12} \mathrm{C}$, and both global and local geographic reservoir effects (Stuiver, et al., 1998). The calibations were calculated using the latest (1998) calibration database (Stuiver, et al., 1998; Talma and Vogel, 1993). Ages (Table 4.2) have the units "B.P." (Before Present), where "Present" is defined as A.D. 1950 for the purposes of radiocarbon dating. 


\section{Preparation and Identification of Benthic Foraminifera}

Two hundred and three sediment samples were soaked in freshwater to disaggregate sediments, then sieved to obtain grain sizes $>63 \mu \mathrm{m}$, which includes all adult and nearly all juvenile foraminifera. The sample residues were split until 300-400 specimens (a statistically significant sample) could be picked from a sample split (Murray, 1991). The foraminifera were picked, sorted onto cardboard slides and identified to species under the light microscope.

Foraminifera were identified to the species level. There are considerable taxonomic and ecologic data on benthic foraminiferal populations collected from bays and estuaries along the Atlantic and Gulf of Mexico coasts. Species were identified following, Bock et al. (1971), Rose and Lidz (1977), Wantland (1967), and Buzas and Severin (1982), among others. The identifications in many cases were checked against type specimens at the U.S. National Museum of Natural History. The online Catalogue of Foraminifera (Ellis and Messina, 1941-2009) was used for the original descriptions of species. The full names of taxa are listed in Appendix 1.

\section{Data Analysis}

Three statistical methods were used to analyze the results, as follows. Counts of species with more than $1 \%$ abundance in any sample were transformed from percentage data using the relationship $2 \arcsin \mathrm{p}^{1 / 2}$, where $\mathrm{p}=$ percentage datum (Collins, 1993). 5The stratigraphically constrained cluster analysis CONISS (Grimm, 1987) was performed to determine the associations between the foraminiferal distributions. It is a multivariate method for quantitative definition of stratigraphic zones. As opposed to the standard, 
unconstrained cluster analysis, only stratigraphically adjacent clusters are considered for merging, so the larger habitat changes can be more easily identified. The method of incremental sum of squares has been used widely for unconstrained cluster analyses.

Cluster analysis (unconstrained), a multivariate procedure for detecting natural groupings in data, was also performed. The samples were grouped using Ward's method, one of the best available hierarchical clustering algorithms (Milligan, 1980), to calculate the distance between two clusters as the sum of squares between the two clusters added up over all the species (Wilkinson et al., 2004). In this study, the Ninemile Bank core recorded habitat changes over the past 4000 years, from the initial flooding to its offshore location. Therefore, all samples from Trout Cove and Ninemile Bank cores were clustered to investigate whether any samples from Ninemile Bank were similar to Trout Cove. Trout Cove is near the mainland next to mangroves. Clustering samples from these two cores should identify any previously nearshore samples contained in the Ninemile Bank core, which aids in investigating sea level change over the last 4000 years.

The index Fisher's $\alpha$ was used to measure diversity of the assemblages. The diversity within a particular area is commonly used as supporting information for indicating specific environmental conditions. Fisher's $\alpha$ is a mathematical model defined by the formula: $S=\alpha x \ln (1+n / \alpha)$, where $S$ is the number if species, $n$ is the number of individuals, and $\alpha$ is the diversity index (Hayek and Buzas, 1997).

\section{Results}

A total of 76 benthic foraminiferal species from 203 samples collected from six cores of Florida Bay are identified. The number of species per sample ranges from 25 to 36 . The 
foraminiferal assemblages are dominated by calcareous forms, with agglutinated species constituting a minor component in most of the assemblages $(<1 \%)$. The most abundant taxa are Discobidae, Rotaliidae, Elphidiidae and Miliolidae. Soritidae such as Archaias angulatus, Articulina mucromata, Peneroplis proteus and Spiroculina exima appear at fairly low frequencies. The generally occurring hyaline species include Ammonia beccarii, Rosalina floridana, Elphidium galvenstonense, Elphidium poeyanum, Elphidium mexicanum and Haynesina depressula. The common miliolids include Heterillina cribrostoma, Triloculina fitterei, T. rotunda, Biloculina eburnea, Quinqueloculina akneriana, Q. bosciana, Q. polygona, Q. poeyana, Q. subpoeyana and Paeteoris dilatata. Other miliolids occurring at relatively low frequency include $Q$. angulatus, $Q$. agglutinans, Q. bicornis, Q. bidentata, Q. laevigata and Pyrgo elongata. Agglutinated taxa in this core include Ammobaculites exiguus and Clavulina tricarinata.

Two major foraminiferal associations are defined: an Ammonia beccarii association and a Quinqueloculina spp. association (Table 4.3), based on the literature (Phleger, 1966; Lidz and Rose, 1989; Murray, 1991). The Ammonia beccarii association is generally related to the mangrove environment with a salinity range between $0-20$, while the Quinqueloculina spp. association is generally found in the marine environment with relatively higher salinities between 30-40.

Bob Allen Core \#0206122: A total of 45 benthic foraminiferal species from 18 samples were identified and counted (Figure 4.2). The number of species per sample ranges from 17 to 27 . The most abundant species are $A$. beccarii, Rosalina spp., Elphidium spp., $H$. depressula, H. cribrostoma, T. fitterei, B. eburnea, Q. bosciana and Q. poeyana. Between 1889 and 1905, the Quinqueloculina spp. association dominated the assemblages. 
Ammonia beccarii and Elphidium spp. showed higher relative abundances between 1906 and 1933, while H. cribrostoma and T. fitterei showed lower relative abundances during this period. Haynesia depressula and Q. poeyana showed lower abundances between 1906 and 1983. Rosalina floridana and Q. bosciana remain fairly steady with minor fluctuations.

The CONISS cluster analysis (Figure 4.2) separates the samples into two major clusters: Cluster 1 between 78-48 cm (1889-1933), and Cluster 2 between 42-2 cm (1942-2001). Within Cluster 1, there are two subclusters: Cluster 1a between 78-66 cm (1889-1906), and Cluster $1 \mathrm{~b}$ between 62-48 $\mathrm{cm}$ (1912-1933). Within Cluster 2, there are two subclusters: Cluster 2a between 42-10 cm (1942-1989), and Cluster $2 \mathrm{~b}$ between 6-2 cm (1996-2001). Cluster 1a is distinguished from Cluster 1b by trends such as its lower relative abundance of $A$. beccarii, and higher relative abundance of $H$. cribrostoma and $H$. depressula. Cluster 2a is best characterized by the low abundance of $A$. beccarii and Elphidium spp. and greater abundance of $H$. cribrostoma. Cluster $2 \mathrm{~b}$ contains higher relative abundances of Q. akneriana and Q. poeyana. Fisher's $\alpha$ (Figure 4.3) generally fluctuated at lower values ( 6), but showed slightly higher values ( 8) around 1977-1987.

Bob Allen Core \#0206124: A total of 45 benthic foraminiferal species from 29 samples were identified and counted. The number of species per sample ranges from 17 to 27 . Species dominance varied considerably through the last $\sim 120$ years. The five most abundant taxa in the core are R. floridana, Elphidium spp., H. depressula, H. cribrostoma and Q. bosciana. Ammonia beccarii, T. fitterei and B. eburnea occur with relatively lower frequency than the above species (Figure 4.4). The most distinctive pattern is the higher relative abundance of $A$. beccarii and Elphidium spp. and the lower values for $H$. 
cribrostoma and Q. bosciana at approximately 1832 (but ${ }^{210} \mathrm{~Pb}$ dating ages this old are somewhat unreliable). Between 1832 and 1855, the Quinqueloculina spp. association (Table 4.3) dominated the assemblages.

The CONISS cluster analysis (Figure 4.4) separates all the samples into two major clusters: Cluster 1 between $68-64 \mathrm{~cm}\left({ }^{210} \mathrm{~Pb}\right.$ dating extrapolated to $\left.1805-1816\right)$, and Cluster 2 between 60-2 cm (1827-1987). Within Cluster 2, there are two subclusters: Cluster 2a between $60-30 \mathrm{~cm}$ and Cluster $2 \mathrm{~b}$ between $28-2 \mathrm{~cm}$. The higher relative abundance of $A$. beccarii and Elphidium spp. and lower relative abundance of miliolids distinguishes Cluster 1 from Cluster 2. Fisher's $\alpha$ (Figure 4.3) fluctuated in this core, but shows a gradual decline from $\sim 6-8$ in the mid-1800s to around 6 in the late 1800 s-early 1990s. After a drop between 1937-1947, it fluctuated around $\sim 5$ in the late 1900s.

Russell Key Core \#0206125: A total of 51 benthic foraminiferal species from 37 samples were identified and counted in this core. The number of species per sample varied from 17 to 33. The common taxa are Discobidae, Rotaliidae, Elphidiidae and Miliolidae. Soritidae compose less than $5 \%$ of the total assemblage in all samples. Agglutinated species were rarely found in the samples, which may be because many species with this wall type are not preserved as well as calcareous taxa are. The most abundant species are Ephidium spp., H. cribrostoma, T. fitterei, B. eburnea and $Q$. bosciana (Figure 4.5). Before 1905, the foraminiferal assemblages were dominated by the Quinqueloculina spp. Association (Table 4.3). The Ammonia beccarii association was in greater abundance after 1927. Triloculina fitterei shows a generally increasing trend throughout the core. Biloculina eburnea remained steady until 1963, when it started to 
decrease. Rosalina floridana, $H$. cribrostoma and $Q$. bosciana remained fairly steady during the whole period.

The CONISS cluster analysis (Figure 4.5) divides the samples into two main clusters: Cluster 1 between 140-92 cm (1884-1925) and Cluster 2 between 88-2 cm (1928-2001). Cluster 1 is distinguished from Cluster 2 by the high abundance of $Q$. poeyana and $T$. fitterei, and lower abundance of B. eburnea. Fisher's $\alpha$ (Figure 4.3) shows its lowest values of $\sim 4-5$ around 1884-1924, then an increasing trend to $\sim 6$ until a drop back to $\sim 4$ around 1965-1970. After 1975 Fisher's $\alpha$ has a higher relative value of $\sim 7-8.5$.

Russell Key Core \#0206127: A total of 51 benthic foraminiferal species from 24 samples were identified and counted in this core. The number of species per sample varied from 18 to 35 . Similar to core \#0206125 (above), the common taxa are Discorbidae, Rotaliidae, Elphidiidae and Miliolidae in this core. The most abundant species are A. beccarii, Elphidium spp., H. cribrostoma, B.eburnea and Q. bosciana (Figure 4.6). Ammonia beccarii had a gradually increasing trend from 1932 to 2001. Elphidium galvenstonense and E. mexicanum did not appear until 1932. Heterillina cribrostoma gradually decreased to its minimum abundance at 1966, and then increased again. Both T. fitterei and B. eburnea were in high abundance between 1918-1932 and between 1980-2001.

The CONISS cluster analysis (Figure 4.6) separates the samples into two major clusters: Cluster 1 between 150-124 cm (1918-1932) and Cluster 2 between 112-2 cm (1938-2001). Cluster 1 is characterized by the absence of $A$. beccarii, E. galvenstonense and $E$. mexicanum, as well as a high abundance of H. cribrostoma, T. fitterei and B. eburnea. Fisher's $\alpha$ (Figure 4.3) was relatively low ( $\sim$ ) between 1918 and 1925, then gradually 
increased to a peak of 10 at 1974 . After that, $\alpha$ dropped and then fluctuated around 6 with no obvious increasing or decreasing trends.

Trout Cove Core \#02061211: A total of 45 benthic foraminiferal species were recognized in this core. The number of species per sample ranges from 16 to 28 . The most abundant taxa in the core samples are $A$. beccarii, Elphidium spp., Rosalina spp., $Q$. bosciana, H. cribrostoma and $H$. depressula. The percent abundance of these species varied through time (Figure 4.7). Unlike the cores from the other three sites, all the samples from the Trout Cove core contain lower percentages of miliolids. The Ammonia beccarii association remained constant throughout the core.

The CONISS cluster analysis (Figure 4.7) separates all the samples into two main clusters: Cluster 1 between $96-76 \mathrm{~cm}\left({ }^{210} \mathrm{~Pb}\right.$ dating, very approximately $\left.1130-1265\right)$ and Cluster 2 between $72-2 \mathrm{~cm}$ (1891-1994). Cluster 1 is characterized by the higher relative abundance of $A$. beccarii. Fisher's $\alpha$ (Figure 4.3) had a value of 4-6 before the mid-1800s $\left({ }^{210} \mathrm{~Pb}\right.$ dating approximate), increased to higher values of $\sim 6$ between the mid-1800s to $\sim 1940$, dropped to lower values of about $\sim 5$ between 1948 and 1980, and sustained its highest values around $\sim 7$ between 1984 and 1994 .

Ninemile Bank Core \#0208134: A total of 48 benthic foraminiferal species were identified in this core. The number of species per sample ranges from 19 to 39. Among them, A. beccarii, B. eburnea, Elphidium spp., H. depressula, H. cribrostoma, $Q$. bosciana, Rosalina spp. and T. fitterei dominate the assemblages (Figure 4.8). Soritidae are more abundant in this core than in the Bob Allen Bank cores and Russell Key cores. Agglutinated species such as Ammobaculites exiguus are present at low frequency in the samples at 50-2 cm, around 1938-2001. The Ammonia beccarii association is more 
abundant in the samples between 242-112 cm, while the Quinqueloculina spp. association is relatively abundant between 182 and $2 \mathrm{~cm}$. Haynesina depressula generally increased in abundance through the core, while H. cribrostoma gradually decreased. Rosalina spp. and $Q$. bosciana remained fairly constant throughout the core.

The CONISS cluster analysis (Figure 4.8) separates the samples into two major clusters: Cluster 1 between $242-112 \mathrm{~cm}\left({ }^{14} \mathrm{C}\right.$ dating, estimation of B.P. $\left.4000-\sim 2000\right)$ and Cluster 2 between 110-2 cm (B.P. 2000 -A.D. 2001). Within the latter cluster, there are three subclusters: Cluster 1a between 242-238 cm (approximate age before B.P. 3800), Cluster $1 \mathrm{~b}$ beween 230-182 $\mathrm{cm}$ (approximate age B.P. 3800-B.P. 3200), and Cluster 1c between 180-112 cm (approximate age B.P. 3200-B.P. 2340). Within Cluster 2, there are two subclusters: Cluster 2a between 110-54 cm (approximate age B.P. 2340-A.D. 1932), and Cluster $2 \mathrm{~b}$ between $48-2 \mathrm{~cm}$ (A.D. 1940-A.D. 2001). Cluster 1a is characterized by an extremely high abundance of $A$. beccarii and Elphidium spp., which compose almost $80 \%$ of the assemblages. Cluster $1 \mathrm{~b}$ shows a major shift to foraminiferal assemblages dominated by $H$. cribrostoma. Increases in A. beccarii and Elphidium spp. and decreases in $H$. cribrostoma characterize Cluster 1c. Cluster 2a contains high percentages of $H$. cribrostoma, B. eburnea, and Q. bosciana. Cluster $2 \mathrm{~b}$ is best characterized by the high abundance of $H$. depressula, Ammobaculites exiguus, Bolivina lanceolata and Bolivina inflata.

Fisher's $\alpha$ at Ninemile Bank (Figure 4.9) was lowest near the base of the core, within the mangrove peat samples. It then rose to fluctuate at values of generally $\sim 5-8$ until 1909 , when it dropped to near 4. After this, it rose to its highest values of 8-12, between 1970 and 2001. An unconstrained cluster analysis (Ward's method, Figure 4.10) clearly 
separates the samples from Ninemile Bank and Trout Cove into two major clusters. Only three samples from Ninemile Bank, the bottom two samples and the sample of 160-162 $\mathrm{cm}$, were clustered together with Trout Cove samples.

\section{Discussion}

Three of the six cores contain samples of sediments deposited before 1880, the approximate lower limit of ${ }^{210} \mathrm{~Pb}$ dating (discussed in section II, above). Therefore, the foraminiferal assemblages collected from these older samples are discussed below by their estimated approximate ages.

Trout Cove, the nearshore site, shows different trends from the other sites in both diversity and composition of foraminiferal assemblages. The assemblages were always dominated by the $A$. beccarii association, indicating a habitat of intertidal mangrove swamps. Furthermore, besides the similarity to the composition of mangrove swamps assemblages (unpublished data of Collins), diversity was also relatively low as indicated by Fisher's $\alpha$ (Figure 4.3), supporting the interpretation of a mangrove swamp habitat.

The results for the four cores from the central bay will be discussed below in chronological order. In Bob Allen Core \#0206124, the high diversity between $\sim 1805$ and $\sim 1855$ and high abundance of the Quinqueloculina spp. association suggests a normal marine habitat. The extremely high abundance of miliolids between 1860 and 1877 (Figure 4.4) suggests a hypersaline environment (Hill et al., 2003), a more extreme habitat that is supported by a corresponding diversity decrease (Figure 4.3).

Between 1880 and 1905, the samples from Bob Allen Bank and Russell Key were mainly dominated by the Quinqueloculina spp. association. Epifaunal species such as $H$. 
cribrostoma, Quinqueloculina spp. and Triloculina spp. dominated the assemblages. Generally, these species live above the sediments and prefer marine-hypersaline (32-65 psu) conditions (Table 4.4). Therefore, the high abundance of these species was most likely the result of high salinity ( $>32 \mathrm{psu}$ ) in this period.

Between 1906 and 1940, foraminiferal assemblages from the central bay changed their composition in all four cores, and the change indicates a switch to brackish conditions. Between 1906 and 1933, the foraminiferal assemblages at Bob Allen Bank cores were dominated by the $A$. beccarii association, which prefers an infaunal, brackish environment (0-30 psu, Table 4.3). The shift from epifaunal, marine to infaunal, brackish assemblages around 1906 indicates a large habitat change, supported by increasing diversity. The higher relative abundance of the $A$. beccarii association in Russell Key Core \#0206125 between 1925 and 1940 suggests more brackish conditions. Moreover, diversity was relatively low, indicating environmental stress. Diversity was also low in Russell Key Core \#0206127 between 1918 and 1930, when the foraminiferal assemblages were mainly dominated by the brackish species. Furthermore, infaunal species dominated the assemblages at Russell Key in this period, indicating a habitat different from those of any other period.

Between 1905 and 1940, the shift in foraminiferal assemblage composition and Fisher' $\alpha$ at Bob Allen Bank and Russell Key suggests an obvious habitat change in the central bay. This change was also in accordance with the construction of the Flagler Railroad from Miami to the Florida Keys between 1905 and 1912, the building of canals in the Everglades and the Tamiami Trail from Miami to the west coast between 1907 and 1929, and the higher precipitation during an Atlantic Multidecadal Oscillation cool phase 
(Enfield et al., 2001). The man-made structures either blocked the water exchange between Florida Bay and the Atlantic Ocean, or reduced the freshwater input from the Everglades. The correspondence between these events and changes in assemblages indicates that the habitat changes may have been caused by these human activities. Furthermore, Bolivina species appeared in Bob Allen Bank cores \#0206124 and \#0206125 between 1905 and 1915, indicating more organic-rich, lower oxygen condition. The great abundance of the infaunal species A. beccarii, Elphidium spp. and $H$. depressula, which prefer living in sediments with little oxygen (Scott et al., 2001), support a lower oxygen environment during this period. The construction of the railway restricted access between the bay and the reef tract, allowing a buildup of products from the oxidation of organic carbon in the central bay (Swart et al., 1996, 1999).

After 1942, the assemblages in both cores from Bob Allen Bank returned to domination by epifaunal miliolids, which prefer living above the sediments and in marine conditions, suggesting a different habitat. Ammonia beccarii, E. poeyanum and H. depressula, generally infaunal species (Table 4.4), greatly increased their abundance in core \#0206122 from 1983 to 2001, supporting an interpretation of less hospitable conditions. A dramatic decrease in diversity after 1987 indicates an increase in environmental stress, which corresponds to the 1987-1994 seagrass dieoff (Chapter 2). In addition, the low abundances of the epiphytic species C. involvens, $Q$. polygona and T. rotunda between 1986 and 1994 also suggest a more stressful environment during the seagrass dieoff. In the Russell Key cores, the consistently high abundance of miliolids indicates a marine environment with salinity over 30 psu (Hill et al., 2003). 
In the Ninemile Bank core, the A. beccarii association (Table 4.3) dominated foraminiferal assemblages in the bottom peat samples (Figure 4.8). The association and an extremely low diversity indicate a mangrove environment before $\sim$ B.P. 3800-3530. This agrees with an age estimate of B.P. 4000 for initial marine flooding of the Florida Bay area (Enos, 1989). These two bottom samples were clustered with other Trout Cove samples (Figure 4.10), which further demonstrates that the environment in the western bay before B.P. 3800 was similar to the present one at Trout Cove. After this, the drop in abundance of the A. beccarii association with an increase in the Quinqueloculina spp. association (Table 4.3, Cluster $1 \mathrm{~b}$ of Figure 4.8), H. cribrostoma and Q. bosciana (approximately B.P. 3800-3530 to 3360-3200) and a higher diversity suggest that the habitat shifted to normal marine. After this period, Fisher's $\alpha$ was relatively low without apparent changes in the dominance of abundant species, suggesting a more stressed environment. Between B.P. 3360-3200 (Cluster 1b of Figure 4.8) and B.P. 2660-2340 (Cluster 1c), Fisher's $\alpha$ increased from $\sim 5$ to $\sim 6$, and the abundance of the epifaunal Quinqueloculina spp. association largely decreased, while the infaunal, brackish species A. beccarii, Elphidium spp. and $H$. depressula again dominated the foraminiferal assemblages.

In the (stratigraphically unconstrained) cluster analysis (Figure 4.10), one sample (160$162 \mathrm{~cm}$ ) from Cluster 1c is clustered with the 1937-1994 samples from Trout Cove, suggesting that the habitat at Ninemile Bank during the period of approximately B.P. $\sim 3000$ was similar to that of the present Trout Cove. Furthermore, the diversity of the sample is also within the average range of the top three samples from Trout Cove. These data support a sea level regression around B.P. $\sim 3000$, originally proposed by Fairbridge 
(1974). Another possible reason is a long-term, higher precipitation rate that would reduce salinities to that of present-day Trout Cove, although no other research has suggested this. The other samples within Cluster 1c were dominated by the $A$. beccarii association, but not clustered with Trout Cove samples, suggesting that the habitat at Ninemile Bank between B.P. 3600-3200 and B.P 2660-2340 (except for the period around B.P. 3000) was different from Trout Cove.

At approximately A.D. 1880-1932 (Cluster 2a of Figure 4.8) the assemblages have a lower abundance of the $A$. beccarii association (A. beccarii and E. galvestonense), a higher abundance of $H$. cribrostoma, B. eburnea and $Q$. bosciana, and a relatively high diversity, suggesting a different, normal marine habitat. Following that, at approximately 1937-2001 (Cluster 2b of Figure 4.8), Ammonia beccarii and H. depressula greatly increased. The agglutinated species Ammobaculites exiguus became relatively common. All of these species prefer a brackish, infaunal habitat. Bolivina spp. (which are also typically infaunal) showed a higher abundance in this period too, suggesting more organic-rich, lower oxygen conditions (Sen Gupta, 1999; Ishman, 2001), possibly the result of increased oxidation of organic matter caused by decreased circulation in western Florida Bay (Swart et al., 1999). Furthermore, the addition of the agglutinated and Bolivina species resulted in a diversity that was much higher than during any other period.

\section{Conclusions}

Analyses of 203 samples of benthic foraminifera from six cores indicate habitat changes in Florida Bay over the last $\sim 4000$ years. The changes indicated by shifts in the 
patterns of dominance suggest the influences of both environmental factors and human activities.

The central bay, represented by sites at Bob Allen Bank and Russell Key, showed a habitat change around approximately A.D. $1827\left({ }^{210} \mathrm{~Pb}\right.$ dating $)$ indicated by a large change in assemblage composition at Bob Allen Bank. After 1880, the changes in habitat were most likely connected to anthropogenic and natural events such as the construction of the Flagler Railroad and canals and levees, droughts, and the recent seagrass dieoff (Chapter 2). The core from Trout Cove next to the mainland in northeastern Florida Bay shows less change. Domination by the mangrove swamp species and the consistently low diversity throughout the whole Trout Cove core indicate a mangrove-like, brackish environment for at least the last 1200 years.

The core from Ninemile Bank in far western Florida Bay recorded a history of environmental change over the past $\sim 4,000$ years. The high abundance of the $A$. beccarii association and a very low diversity in the bottom two samples indicate a mangrove-like brackish environment, which agrees with their high content of mangrove peat. Sediments deposited around B.P. $\sim 3000$ contained foraminiferal assemblages similar to those of Trout Cove, suggesting a possible sea level regression or very high precipitation. From 1932 to 2001, a higher abundance of infaunal species and relatively higher percent abundance of (infaunal) Bolivina spp. suggest more organic-rich, lower oxygen conditions, possibly due to long term oxidation of organic matter with decreased circulation caused by construction of the Flagler Railroad in the Florida Keys. 


\section{REFERENCES}

Barbosa, C. F., Scott, D. B., Seoane, J. C. S., and Turcq, B. J., 2005, Foraminiferal zonations as base lines for quaternary sea-level fluctuations in south-southeast Brazilian mangroves and marshes: Journal of Foraminiferal Research, v. 35, p. 22-43.

Bock, W. D., Lynts, G. W., Smith, S., Wright, R., Hay, W. W., and Jones, J. I., 1971, A symposium of recent south Florida foraminifera: Miami Geological Society, Memoir I, $245 \mathrm{pp}$.

Boyer, J. N., and Fourqurean, J. W., 1997, Spatial characterization of water quality in Florida Bay and Whitewater Bay by multivariate analyses: zones of similar influence: Estuaries, v. 20, p. 743-758.

Brewster-Wingard, G. L., and Ishman, S. E., 1999, Historical trends in salinity and substrate in central Florida Bay: a paleoecological reconstruction using modern analogue data: Estuaries, v. 22, p. 369-383.

Buzas, M. A., and Severin, K. P., 1982, Distribution and systematics of foraminifera in the Indian River, Florida: Smithsonian Contributions to the Marine Sciences, no. 16, 45 pp.

Cann J. H., Harvey, N., Barnet, E. J., Belperio, A. P., and Bourman, R. P., 2002, Foraminiferal biofacies eco-succession and Holocene sealevels, Port Piries, South Australia: Marine Micropaleontology, v. 44, p. 31-55

Collins, L. S., 1993, Neogene paleoenvironments of the Bocas Del Toro Basin, Panama: Journal of Paleontology, v. 67, p. 699-710.

Cronin, T. M., Holmes, C. W., Wingard, G., Ishman, S., Dowsett H., and Waibel, N., 2001, Historical trends in epiphytal ostracodes from Florida Bay: Implications for seagrass and macro-benthic algal variability: Bulletins of American Paleontology, v. 361, p. 159-197.

Davies, T. D., and Cohen, A. D., 1989, Composition and significance of the peat deposits of Florida Bay: Bulletin of Marine Science, v. 44, p. 387-398.

Ellis, B. F., and Messina, A. R., 1941-2009, Catalogue of foraminifera, v. 106, 87,000 pp, online: Micropaleontology Press, N.Y.

Enos, P., 1989, Islands in the bay — a key habitat of Florida Bay: Bulletins of Marine Science, v. 44, p. 365-386.

Fairbridge, R. W., 1974, The Holocene sea-level record in south Florida, in Environments of south Florida: present and past, (ed. Gleason, P. J.), Miami Geological Society, Memoir 2. pp. 223-232. 
Fairbridge, R. W., 1976, Shellfish-eating preceramic Indians in coastal Brazil: Science, v. 191, p. 353-399.

Froede, C. R., 2002, Rhizolith evidence in support of a late Holocene sea-level highstand at least 0.5m higher than present at Key Biscayne, Florida: Geology, v. 30, p. 203-206.

Gleason, P. J., and Stone, P., 1994, Age, origin, and landscape evolution of the Everglades peatland, in Davis, S. M., and Ogden, J. C., eds., Everglades: its ecosystem and its restoration: Delary Beach, Florida, St. Lucie Press, p. 149-197.

Grimm, E.C., 1987, Coniss: a fortran 77 program for stratigraphically constrained cluster analysis by the method of incremental sum of squares: Computers and Geoscience, v. 13, p. 13-25.

Halfar, J., and Ingle, J. C., 2003, Modern warm-temperate and subtropical shallow-water benthic foraminifera of the southern gulf of California, Mexico: Journal of Foraminiferal Research, v. 33, p. 309-329.

Hayek, Lee-Ann C., and Buzas, M. A., 1997, Surveying Natural Populations, Columbia University Press, New York, 563 pp.

Hill, T., Brooks, G.R., Duncan, D. S., and Medioli, F. S., 2003, Benthic foraminifera of the Holocene transgressive west-central Florida inner shelf: paleoenvironmental implications: Marine Geology, v. 200, p. 263-272.

Holmes, C. W., Robbins, J., Halley, R., and Bothner, M., 2001, Sediment dynamics of Florida Bay mud banks on a decadal time scale: Bulletins of American Paleontology, v. 361 , p. 31-40.

Horton, B. P., Larcombe, P., Woodroffe, S. A., Whittaker, J. E., Wright, M. R., and Wynn, C., 2003, Contemporary foraminiferal distribution of a mangrove environment, Great Barrier Reef coastline, Australia: implications for se-level reconstructions: Marine Geology, v. 198, p. 225-243.

Horton, B. P., Whittaker, J. E., Thomson, K. H., Hardbattle, M. I. J., Kemp, A., Woodroffe, S. A., and Wright, M. R., 2005, The development of a modern foraminiferal data set for sea-level reconstructions, Wakatobi Marine National Park, Southeast Sulawest, Indonesia: Journal of Foraminiferal Research, v. 35, p. 1-14.

Ishman S. E., 2001, Ecological controls on benthic foraminifera distributions in Biscayne Bay, Florida: Bulletins of American Paleontology, v. 361, p. 233-248.

Lidz, B. H., and Rose, P. R., 1989, Diagnostic foraminiferal assemblages of Florida Bay and adjacent shallow waters: a comparison: Bulletin of Marine Sciences, v. 44, p. 399418. 
Milligan, G. W., 1980, An examination of the effect of six types of error perturbation on fifteen clustering algorithms: Psychometrika, v. 45, p. 325-342.

Missimer, T. M., 1980, Holocene sea level changes in the Gulf of Mexico: An unresolved controversy, in Upchurch, S. B., ed., Holocene geology and man in Pinellas and Hillsborough Counties, Florida: Tallahassee, Florida, Southeastern Geological Society, Southeastern Geological Society Guidebook, v. 22, p. 19-23.

Murray, J. W., 1991, Ecology and Palaeoecology of Benthic Foraminifera, Published in collaboration with the Palaeontological Association, 397 pp.

Phleger, F. B., 1966, Patterns of living marsh foraminifera in south Texas coastal lagoons: Boletin de la Sociedad Geologica Mexiana, v. 28, p. 1-44.

Robbin, D. M., 1984, A new Holocene sea level curve for the upper Florida Keys and Florida reef tract, (eds. Gleason, P. J.), Environments of south Florida, present and past II (second edition): Miami, Florida, Miami Geological Society, p. 437-458.

Rose, R. P., and Lidz, B. H., 1977, Diagnostic foraminiferal assemblages of shallowwater modern environments: south Florida and the Bahamas: Sedimenta VI, 55 pp

Saunders, J. B., 1958, Recent foraminifera of mangrove swampls and river esturaries and their fossil counterparts in Trinidad: Micropaleontology, v. 4, p. 79-92.

Scholl, D. W., Craighead, F. C., and Suiver, M., 1969, Florida submergence curve revisited: its relation to coastal sedimentation rates: Science, v. 163, p. 562-564.

Scott, P. H., Martin, R. E., Nikitina, D., and Pizzuto, J. E., 2000, The formation of Holocene marsh foraminiferal assemblages, middle Atlantic coast, U.S.A.: implication for Holocene sea-level change: Journal of foraminiferal Research, v. 30, p. 272-293.

Scott, D. B., Medioli, F. S., and Schafer, C. T., 2001, Monitoring in coastal environments using foraminifera and thecamoebian indicators: Cambridge University Press, p. 28-93.

Sen Gupta, B. K., 1999, Foraminifera in marginal marine environments, in Modern Foraminifera, (ed B. K. Sen Gupta), Kluwer Academic Publishers, The Netherlands, pp. 157-159.

Shepard, F. P., 1963, Thrity-five thousand years of sea level, (eds. Clements, T.), Essays in marine geology: Los Angeles, University of California Press, p. 1-10.

Stapor, F. W., Jr. Mathews, T. D., and Lindfors-Kearns, F. E., 1987, Episodic barrier island growth in southwest Florida: A response to fluctuating Holocene sea level?, in Maurrasse, (eds. F.J.-M.R.), Symposium on south Florida geology: Miami, Florida, Miami Geological Society Memoir 3, p. 149-202. 
Stapor, F. W., Jr. Mathews, T. D., and Lindfors-Kearns, F. E., 1991, Barrier-island progradation and Holocene sea-level history in southwest Florida: Journal of Coastal Research, v. 7, p. 815-838.

Stuiver, M., Reimer, P. J., Bard, E., Beck, J. W., Burr, G. S., Hughen, K. A., Kromer, B., McCormac, G., Van, D. P. J., Spurk, M., 1998, INTCAL98 radiocarbon age calibration, 24,000-0 cal B.P., Radiocarbon 40, v. 30, p. 1041-1083.

Swart, P. K., Dodge, R. E., and Hudson, H. J., 1996, A 240-year stable oxygen and carbon isotopic record in a coral from South Florida: Implications for the prediction of precipitation in southern Florida, Palaios, v. 11, p.362-375.

Swart, P. K., Healy, G., Greer, L., Saied A., Anderegg, D., and Dodge, R. E., 1999, The use of proxy chemical records in coral skeletons to ascertain past environmental conditions in Florida Bay: Estuaries, v. 22, p. 384-397.

Talma, A. S., Vogel, J. C., 1993, A simplified approach to calibrating 14C dates, Radiocarbon 35, v. 2, p. 317-322.

Toscano, M. A., and Lundberg, J., 1998, Early Holocene sea-level record from submerged fossil reefs on the southeast Florida margin: Geology, v. 26, p. 255-258.

Vance, D. J., Culver, S. J., Corbett, D. R., and Buzas, M. A., 2006, Foraminifera in the albemarile estuarine system, north Carolina: distribution and recent environmental change: Journal of Foraminiferal Research, v. 36, p. 15-33.

Walker, K. J., Stapor, F. W., and Marquardt, W. H., 1995, Archaeological evidence for a 1750-1450 BP higher-than-present sea level along Florida's Gulf Coast, in Finkl, C. W., ed., Holocene cycles: Climate, sea levels, and sedimentation: Journal of Coastal Research, Special Issue 17, p. 205-218.

Wanless, H. R., and Tagett, M. G., 1989, Origin, growth and evolution of carbonate mudbanks in Florida Bay: Bulletins of Marine Science, v. 44, p. 454-489.

Wanless, H. R., Parkinson, R. W., and Tedesco, L. P., 1994, Sea level control on stability of Everglades wetlands: Everglades, The Ecosystem and its Restoration, (ed. by Davis, S. M., Oghen, J. C.), St. Lucie Press, pp. 199-224.

Wantland, K. F., 1967, Recent foraminifera of the British Honduras shelf: unpublished Ph.D. dissertation, Rice University, Houston, Texas, 125 pp.

Wilkinson, L., Engelman, L., Corter, J., and Coward, M., 2004, Cluster analysis: SYSTAT 11, Statistics I, p.57-91. 
Woodroffe, S. A., Horton, B. P., Larcombe, P. L., and Whittaker, J. E., 2005, Intertidal mangrove foraminifera from the central great barrier reef shelf, Australia: implications for sea-level reconstruction: Journal of Foraminiferal Research, v. 35, p. 259-270. 
Table 4.1 Description of coring sites examined in this study. Cores were split into 2-cm samples.

\begin{tabular}{|l|l|l|l|l|}
\hline Site & Latitude (N) & Longtitude (W) & Core length & Water depth \\
\hline $\begin{array}{l}\text { Bob Allen Bank } \\
\text { Core \#0206122 }\end{array}$ & $25^{\circ} 01.670^{\prime}$ & $80^{\circ} 40.871^{\prime}$ & $200 \mathrm{~cm}$ & $48 \mathrm{~cm}$ \\
\hline $\begin{array}{l}\text { Bob Allen Bank } \\
\text { Core \#0206124 }\end{array}$ & $25^{\circ} 01.731^{\prime}$ & $80^{\circ} 40.795^{\prime}$ & $194 \mathrm{~cm}$ & $48 \mathrm{~cm}$ \\
\hline $\begin{array}{l}\text { Russell Key } \\
\text { Core \#0206125 }\end{array}$ & $25^{\circ} 03.871^{\prime}$ & $80^{\circ} 37.501^{\prime}$ & $170 \mathrm{~cm}$ & $46 \mathrm{~cm}$ \\
\hline $\begin{array}{l}\text { Russell Key } \\
\text { Core \#0206127 }\end{array}$ & $25^{\circ} 03.851^{\prime}$ & $80^{\circ} 37.371^{\prime}$ & $170 \mathrm{~cm}$ & $46 \mathrm{~cm}$ \\
\hline $\begin{array}{l}\text { Ninemile Bank } \\
\text { Core \#0208134 }\end{array}$ & $24^{\circ} 57.128^{\prime}$ & $80^{\circ} 53.607^{\prime}$ & $244 \mathrm{~cm}$ & $37 \mathrm{~cm}$ \\
\hline $\begin{array}{l}\text { Trout Cove } \\
\text { Core \#02061211 }\end{array}$ & $25^{\circ} 12.582^{\prime}$ & $80^{\circ} 31.932^{\prime}$ & $96 \mathrm{~cm}$ & $47 \mathrm{~cm}$ \\
\hline
\end{tabular}


Table 4.2 Radiocarbon dates for Ninemile Bank obtained by L. Collins from Beta Analytic Laboratory, Miami, Florida. Ages were corrected for ${ }^{13} \mathrm{C} /{ }^{12} \mathrm{C}$, and global and local geographic reservoir effects (Talma and Vogel, 1993) prior to the calibration $\left({ }^{13} \mathrm{C} /{ }^{12} \mathrm{C}=1.6\right.$; local reservoir effect $=-5 \pm 20$; global reservoir effect $=-200$ to 500$)$. The database of Marine 98 (Stuiver et al., 1998) was used for calibration.

\begin{tabular}{|c|c|c|c|c|c|}
\hline $\begin{array}{l}\text { Core } \\
\text { Location }\end{array}$ & $\begin{array}{l}\text { Core } \\
\text { depth } \\
(\mathrm{cm})\end{array}$ & $\begin{array}{l}\text { Type of } \\
\text { material }\end{array}$ & $\begin{array}{l}\text { Measured } \\
\text { radiocarbon } \\
\text { age (B.P.) }\end{array}$ & $\begin{array}{l}\text { Conventional } \\
\text { radiocarbon } \\
\text { age (B.P.) }\end{array}$ & $\begin{array}{l}\text { Two sigma age } \\
\text { range (Cal. Year } \\
\text { B.P.) }\end{array}$ \\
\hline \multirow[t]{2}{*}{$\begin{array}{l}\text { Trout } \\
\text { Cove }\end{array}$} & $56-58$ & $\begin{array}{l}\text { Three 0.5- } \\
\text { cm-thick } \\
\text { bivalves }\end{array}$ & $250 \pm 40$ & $630 \pm 40$ & $360-240$ \\
\hline & $88-90$ & $\begin{array}{l}\text { 1.3-cm high- } \\
\text { spired } \\
\text { gastropod }\end{array}$ & $1270 \pm 40$ & $1640 \pm 40$ & $1280-1130$ \\
\hline \multirow[t]{5}{*}{$\begin{array}{l}\text { Ninemile } \\
\text { Bank }\end{array}$} & $120-122$ & Brachiodontes & $2340 \pm 40$ & $2750 \pm 40$ & $2660 \sim 2340$ \\
\hline & $152-154$ & Brachiodontes & $2800 \pm 40$ & $3210 \pm 40$ & $3150 \sim 2920$ \\
\hline & $178-180$ & $\begin{array}{l}\text { Three } 0.5-\mathrm{cm} \\
\text { bivalves and } 1 \\
\text { Brachiodontes } \\
\text { fragment }\end{array}$ & $3030 \pm 40$ & $3400 \pm 40$ & $3360 \sim 3200$ \\
\hline & $208-210$ & $\begin{array}{l}\text { One } 0.5-\mathrm{cm} \\
\text { broken } \\
\text { gastropod }\end{array}$ & $3210 \pm 40$ & $3590 \pm 40$ & $3580 \sim 3390$ \\
\hline & $228-230$ & $\begin{array}{l}2 \text { gastropod } \\
\text { fragments, } 1 \\
\text { topshell and } 1 \\
\text { olive shell }\end{array}$ & $3320 \pm 40$ & $3720 \pm 40$ & $3800 \sim 3530$ \\
\hline
\end{tabular}


Table 4.3 Two ecologically defined foraminiferal associations and their habitats (Murray, 1991).

\begin{tabular}{|c|c|c|}
\hline & Ammonia beccarii Association & Quinqueloculina spp. Association \\
\hline Taxa & $\begin{array}{l}\text { Ammonia beccarii } \\
\text { Elphidium galvenstonense } \\
\text { Elphidium poeyanum } \\
\text { Haynesina depressula. }\end{array}$ & $\begin{array}{l}\text { Quinqueloculina spp. } \\
\text { Triloculina spp. } \\
\text { Peneroplis proteus } \\
\text { Archaias angulatus }\end{array}$ \\
\hline Substratum & Calcareous sands and silts & $\begin{array}{l}\text { Turtle grass, carbonate sand, } \\
\text { mud, fine quartz sand }\end{array}$ \\
\hline Habitat & Intertidal mangrove swamps & $<12$ m water depth \\
\hline
\end{tabular}


Table 4.4 General ecology of common species found in Florida Bay (Murray, 1991).

\begin{tabular}{|c|c|}
\hline Genera & Ecology \\
\hline Ammobaculites & $\begin{array}{l}\text { Infaunal; muddy sediment; brackish-marine; } \\
\text { inner shelf - upper bathyal }\end{array}$ \\
\hline Ammonia & $\begin{array}{l}\text { Infaunal, free living; muddy sand; brackish- } \\
\text { hypersaline; } 0-30{ }^{\circ} \mathrm{C} \text {; inner shelf }\end{array}$ \\
\hline Archaias & $\begin{array}{l}\text { Epifaunal; marine; }>22^{\circ} \mathrm{C} \text {; inner shelf- } \\
\text { bathyal }\end{array}$ \\
\hline Articulina & $\begin{array}{l}\text { Epifaunal; marine-hypersaline; }>20^{\circ} \mathrm{C} \text {; inner } \\
\text { shelf-bathyal }\end{array}$ \\
\hline Bolivina & $\begin{array}{l}\text { Infaunal-epifaunal; muddy sediment; marine; } \\
\text { inner shelf-bathyal }\end{array}$ \\
\hline Buliminella & $\begin{array}{l}\text { Infaunal, muddy sediment; marine; mainly } \\
\text { shelf but also lagoons }\end{array}$ \\
\hline Discorbis & $\begin{array}{l}\text { Epifaunal; firm substrate, coarse sand; } \\
\text { marine; } 0-50 \mathrm{~m} \text {; inner shelf }\end{array}$ \\
\hline Elphidium & $\begin{array}{l}\text { infaunal, mud,sand; } 0 \sim 70 \mathrm{psu} \text {; brackish- } \\
\text { hypersaline marshes and lagoons, inner shelf }\end{array}$ \\
\hline Haynesina & $\begin{array}{l}\text { Infaunal, muddy silt; marsh lagoon, inner } \\
\text { shelf }\end{array}$ \\
\hline Miliolinella & $\begin{array}{l}\text { Epifaunal, } 32 \sim 50 \mathrm{psu} ; 10 \sim 30^{\circ} \mathrm{C} ; 0 \sim 100 \mathrm{~m} \text {; } \\
\text { hypersaline lagoons, normal marine and } \\
\text { marshes; inner shelf }\end{array}$ \\
\hline Peneroplis & $\begin{array}{l}\text { Epifaunal, 35 53 psu; } 18 \sim 27^{\circ} \mathrm{C} ; 0 \sim 70 \mathrm{~m} \text {, } \\
\text { lagoons and innermost shelf }\end{array}$ \\
\hline Pyrgo & Epifaunal, marine, inner shelf \\
\hline Quinqueloculina & $\begin{array}{l}\text { Epifaunal, marine-hypersaline; } 32 \sim 65 \mathrm{psu} \text {; } \\
\text { marine }\end{array}$ \\
\hline Rosalina & Epifaunal, hard substratum; marine, $0 \sim 100 \mathrm{~m}$ \\
\hline Sorites & $\begin{array}{l}\text { Epiphytic; especially seagrass; } 37 \sim 45 \mathrm{psu} ; \\
0 \sim 70 \mathrm{~m} \text {; lagoons and nearshore }\end{array}$ \\
\hline Triloculina & $\begin{array}{l}\text { Epifaunal, mud, sand, plants; } \\
\text { marine hypersaline; } 32 \sim 55 \text { psu }\end{array}$ \\
\hline Trochammina & $\begin{array}{l}\text { Epifaunal or infaunal; sediment; } 0 \sim 60 \mathrm{psu} \text {; } \\
0 \sim 30^{\circ} \mathrm{C} ; 0 \sim 6000 \mathrm{~m}\end{array}$ \\
\hline
\end{tabular}




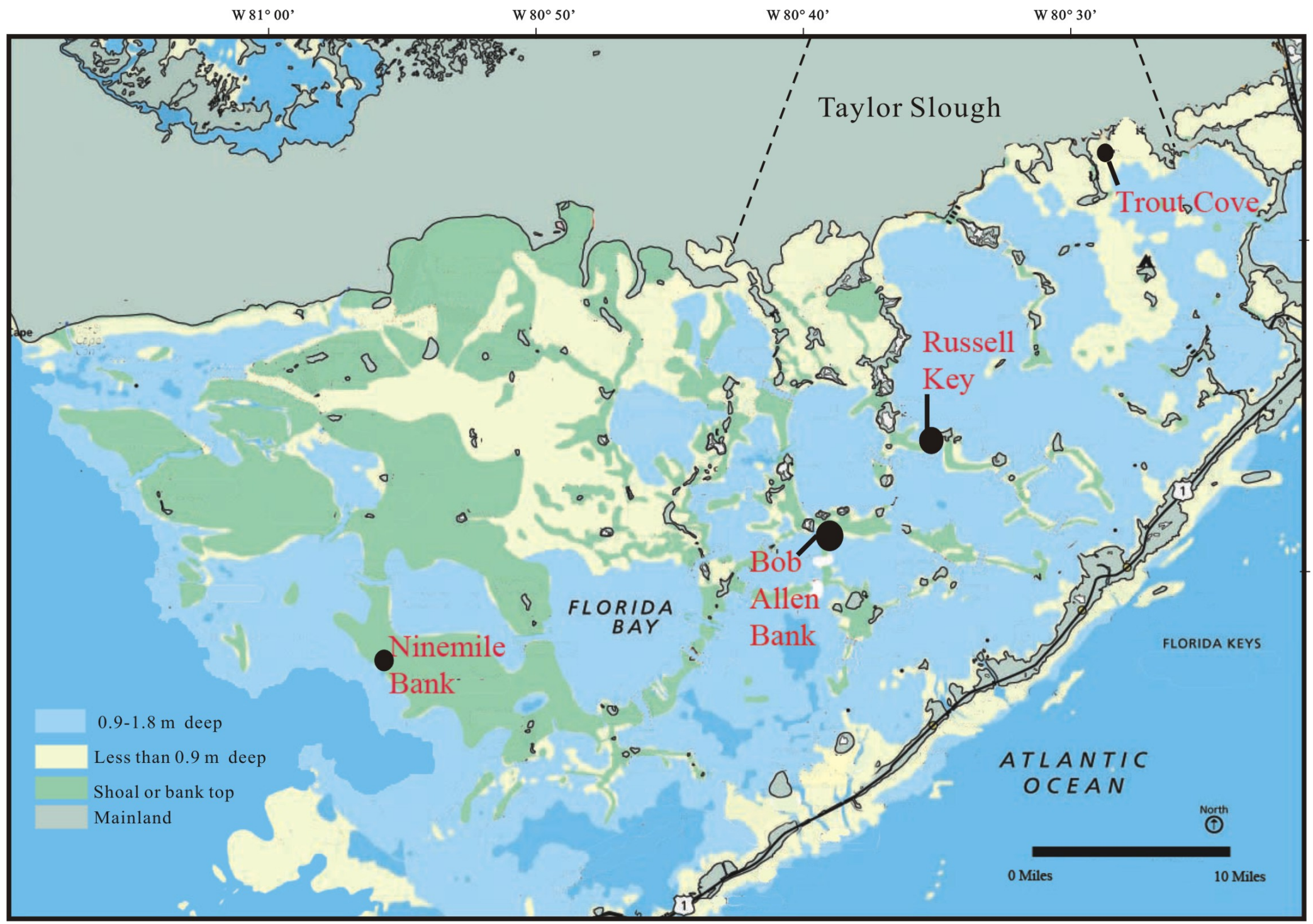

Figure 4.1 Map of Florida Bay showing the four coring sites: Ninemile Bank, Bob Allen Bank, Russell Key and Trout Cove. 


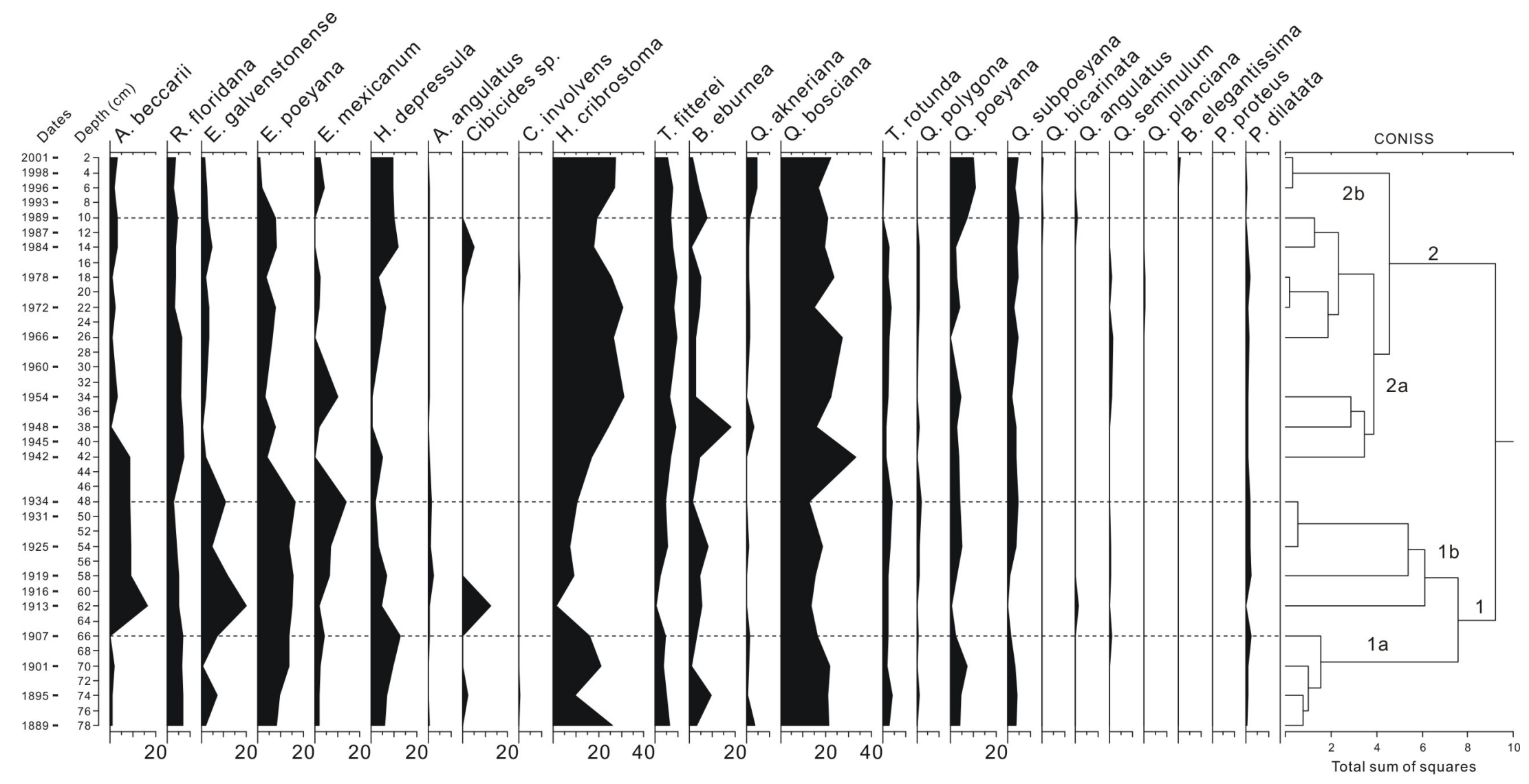

Figure 4.2 Percentages of common benthic foraminifera from Bob Allen Bank Core \#0206122, last 120 years. 


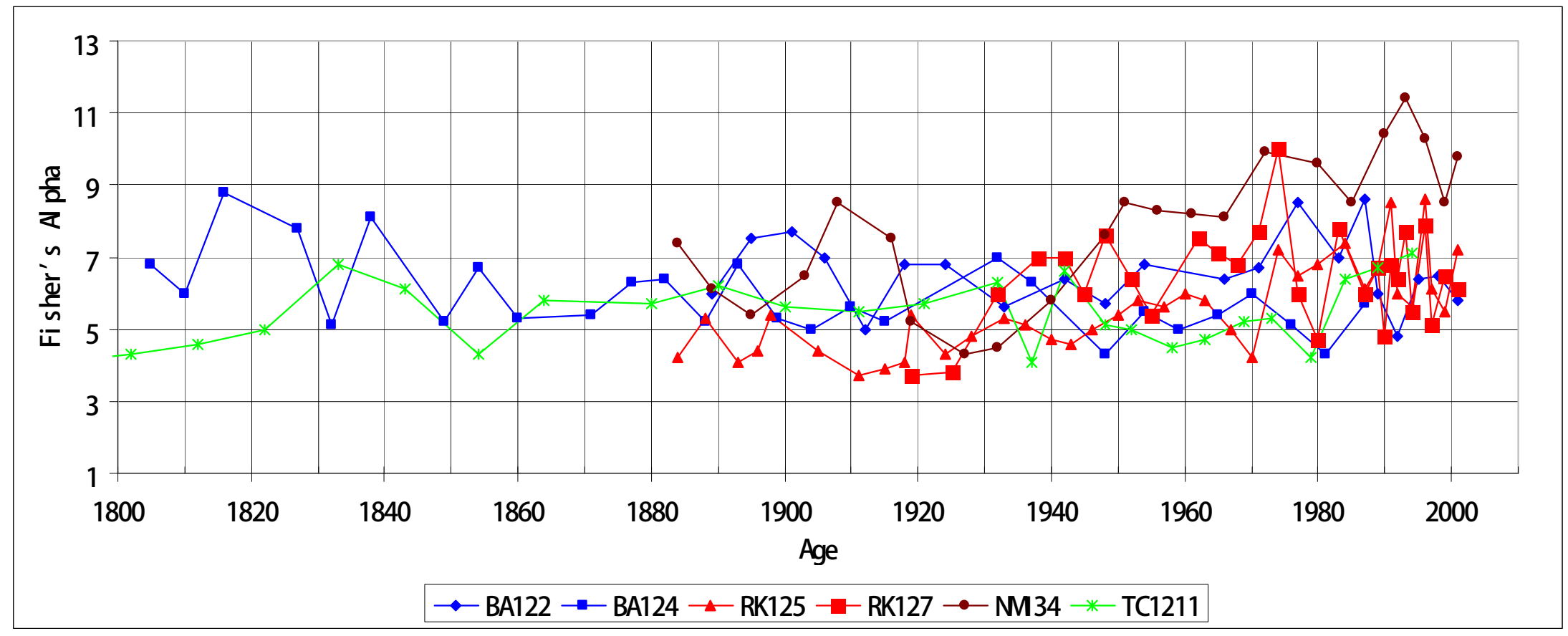

Figure 4.3 Fisher's $\alpha$ from the six cores from Bob Allen Bank (BA), Russell Key (RK), Ninemile Bank (NM) and Trout Cove (TC). 


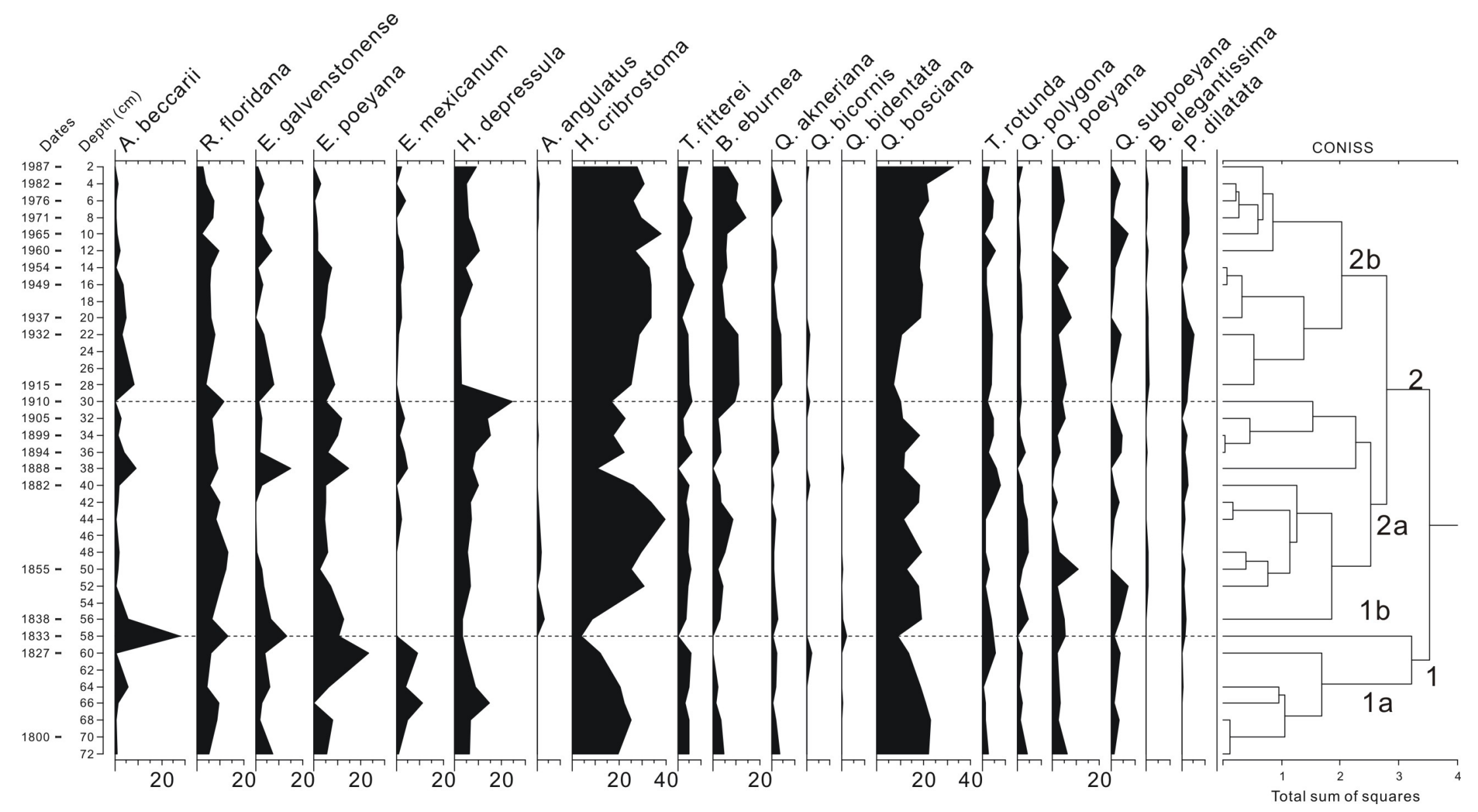

Figure 4.4 Percentages of common benthic foraminifera from Bob Allen Bank Core \#0206124, last 120 years. 


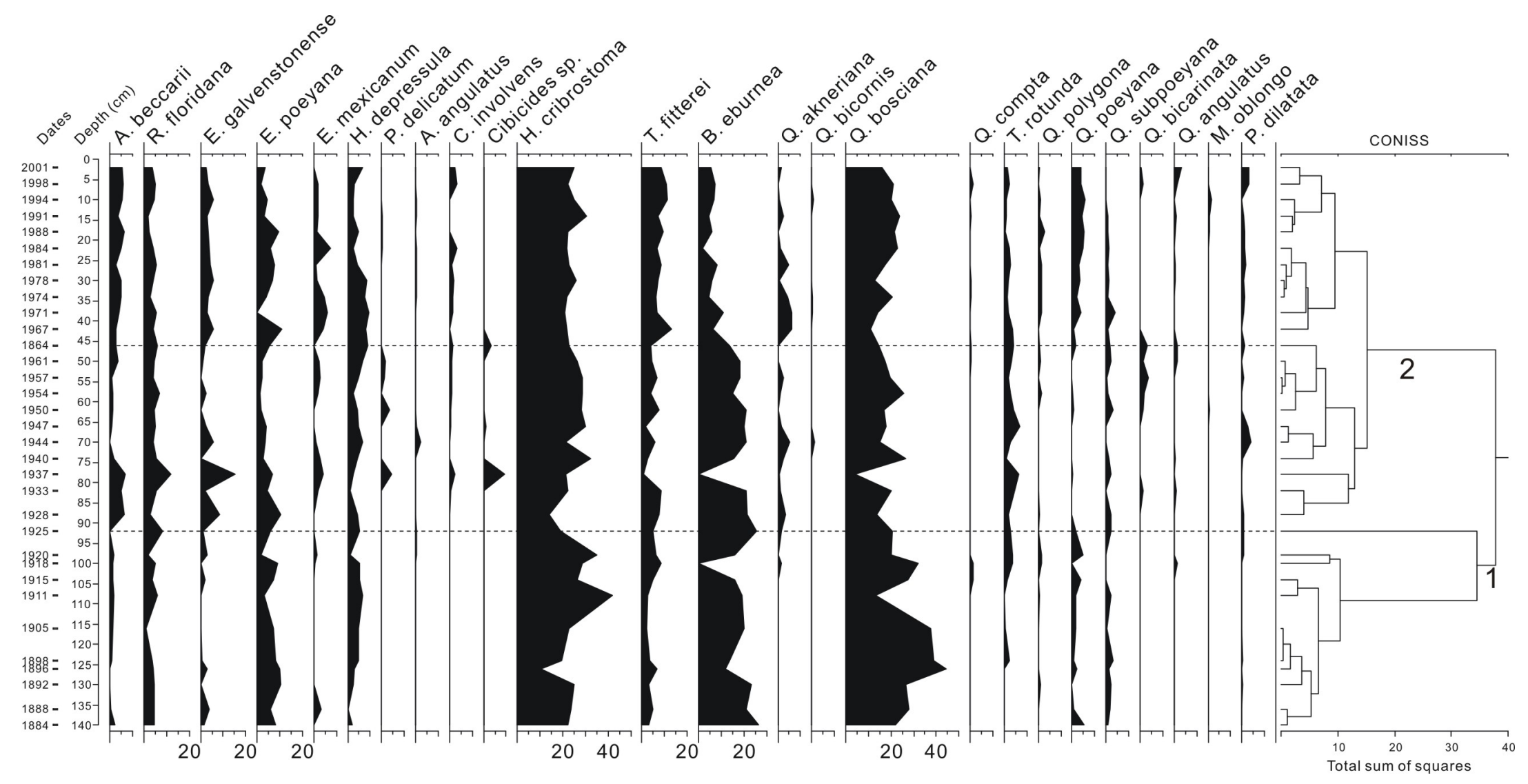

Figure 4.5 Percentages of common benthic foraminifera from Russell Key Core \#0206125, last $~ 120$ years. 


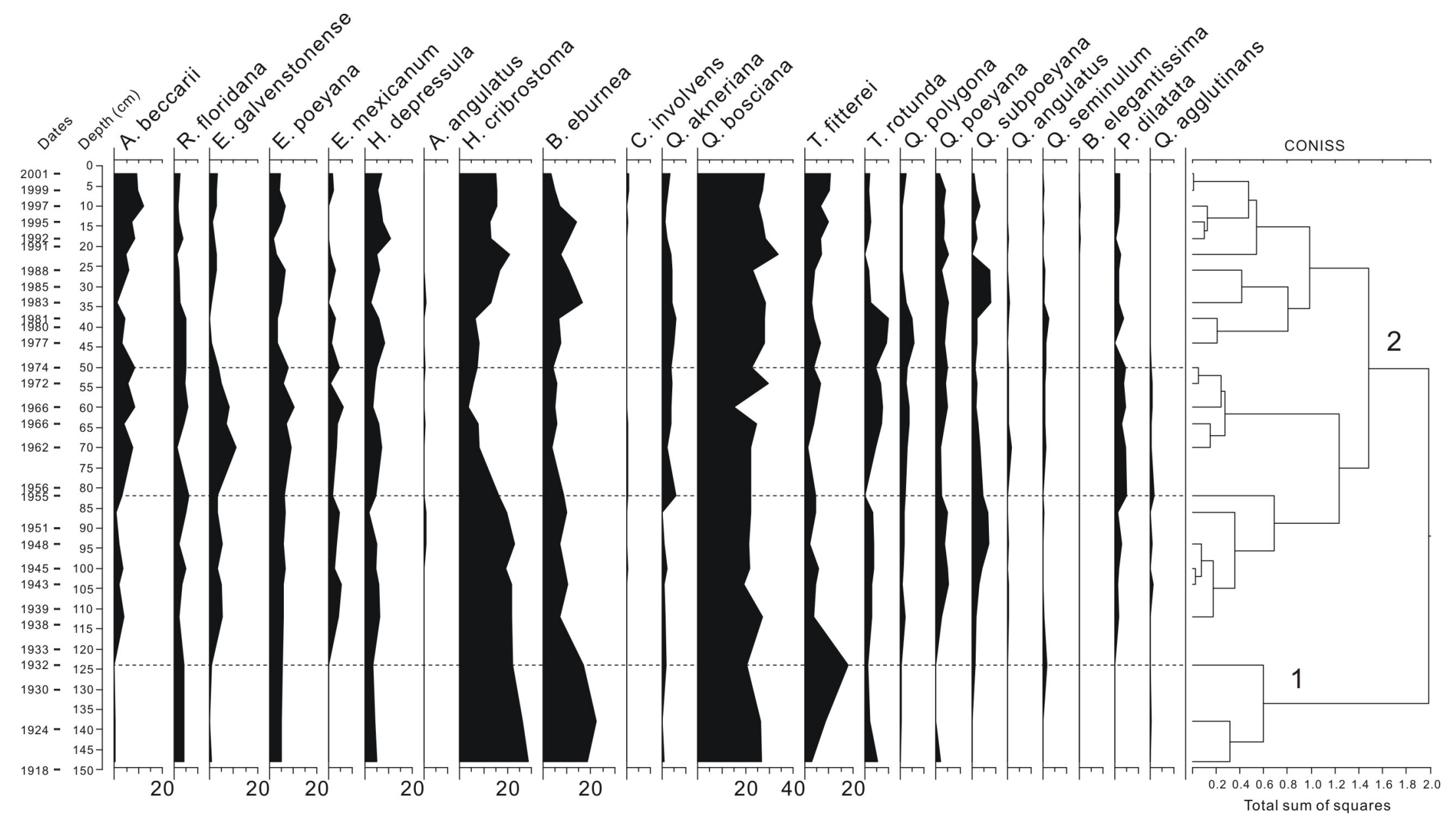

Figure 4.6 Percentages of common benthic foraminifera from Russell Key Core \#0206127, last $\sim 80$ years. 


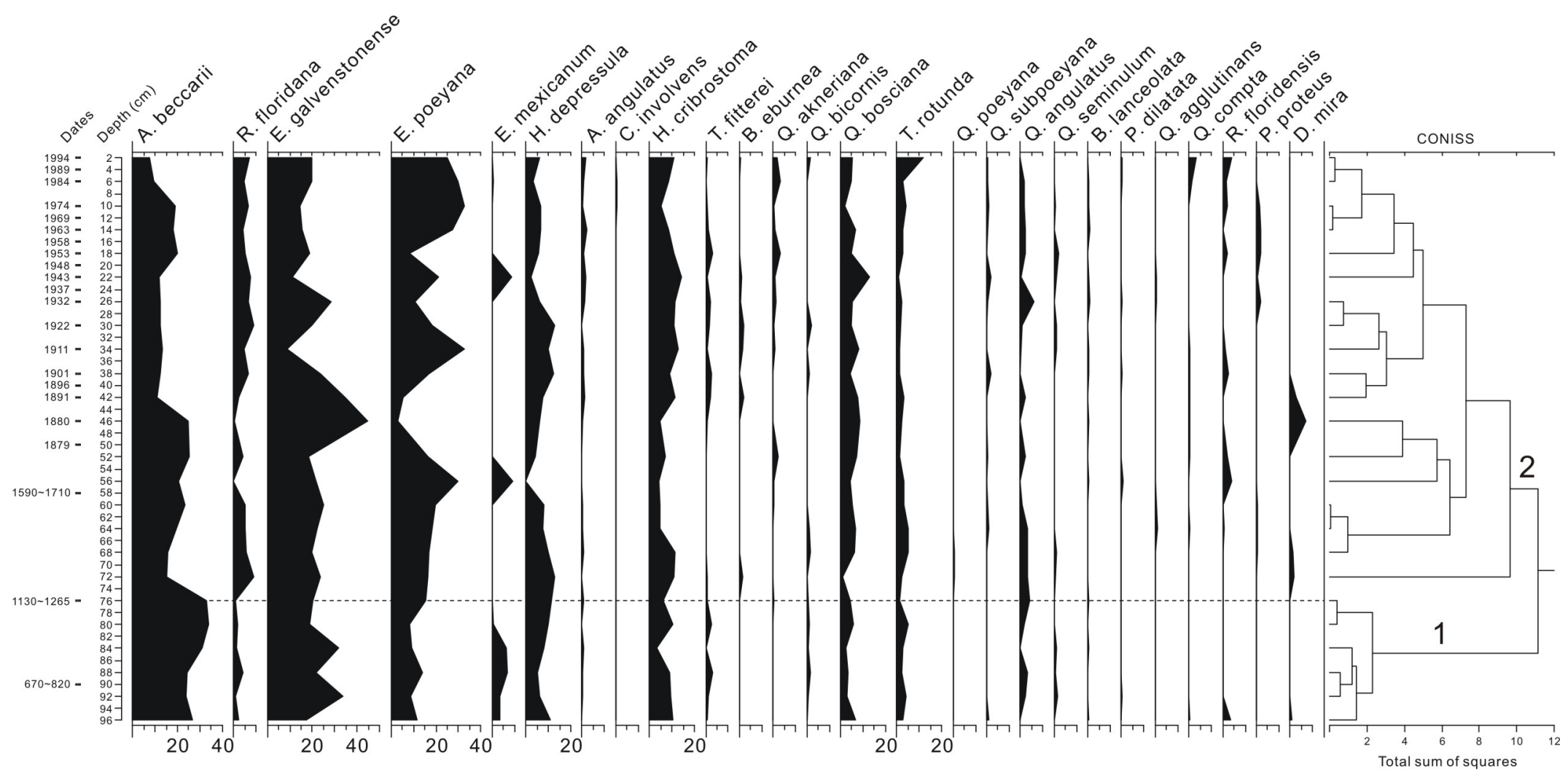

Figure 4.7 Percentages of common benthic foraminifera from Trout Cove Core \#02061211, last 1200 years. 


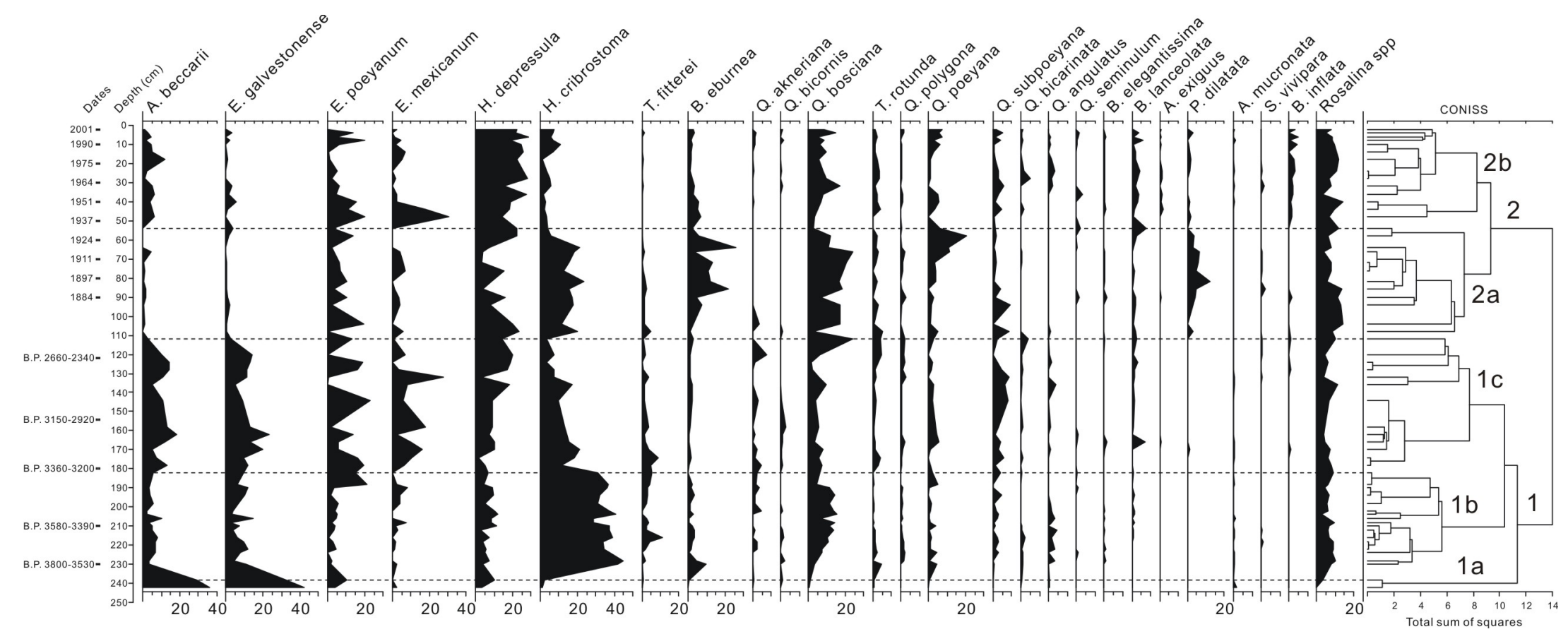

Figure 4.8 Percentages of common benthic foraminifera from Ninemile Bank Core $\# 0208134$, last $\sim 4000$ years. 


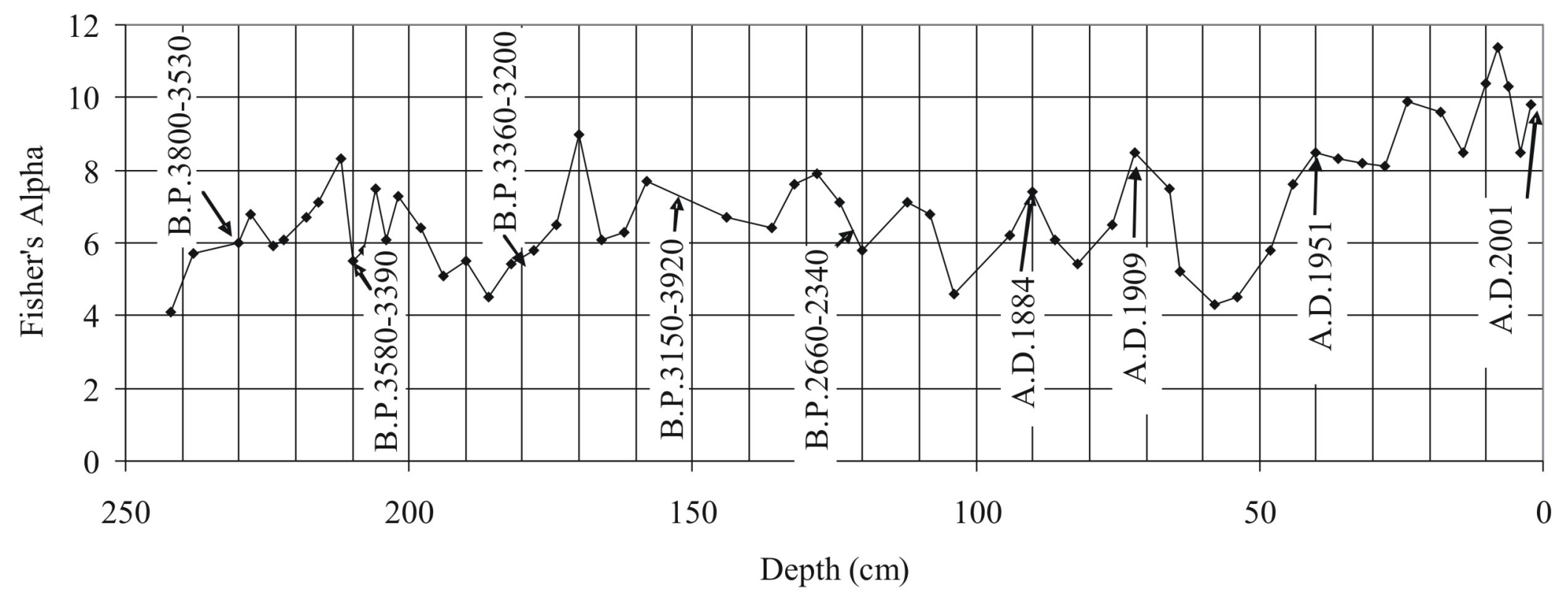

Figure 4.9 Fisher's $\alpha$ from Ninemile Bank, last 4000 years. 


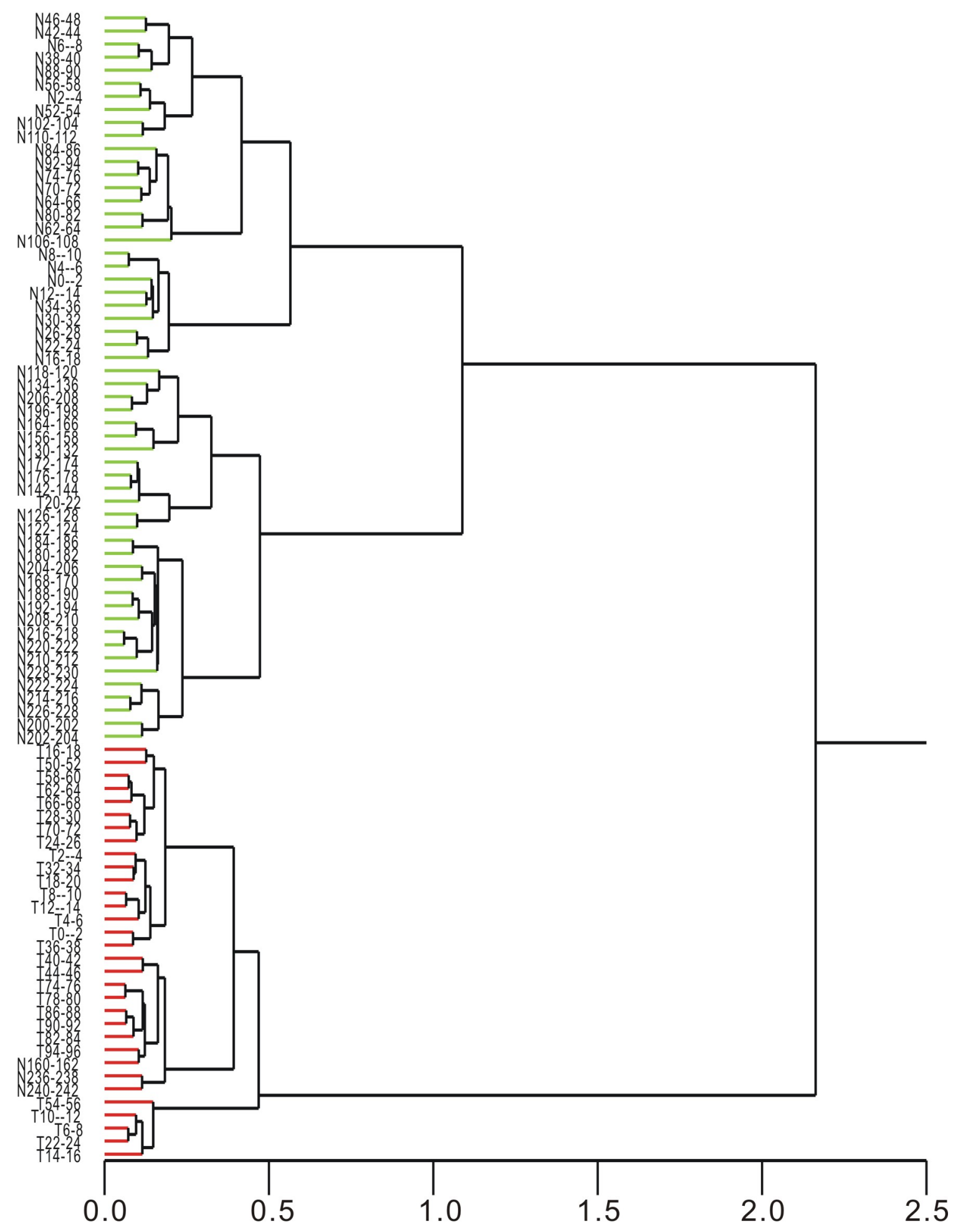

Figure 4.10 Cluster analysis of all studied samples from Ninemile Bank (N) and Trout Cove (T). 


\section{CHAPTER 5}

\section{CONCLUSIONS}

Long-term changes in ecosystems have been recorded since the Cambrian period by the distribution of species of benthic foraminifera, which are generally sensitive to seasonal and annual changes in environmental factors such as seagrass abundance, salinity and temperature. In this study, benthic foraminiferal assemblages in two hundred and three samples from six sediment cores were examined to study historical paleoenvironmental changes of Florida Bay, south Florida. Results of investigations of (1) seagrass abundance, (2) salinity and (3) general habitat change are summarized below and compared.

(1) Seagrass abundance. A list of species that are more associated with seagrass than sediments was compiled from the literature and then tested against the well-documented 1987-1994 seagrass dieoff in Florida Bay to gauge their utility as a proxy for water quality. The dramatic decrease in the percentage of seagrass-associated benthic foraminifera between 1987 and 1994 in all six cores corresponds well to the historical event of seagrass dieoff, indicating the ability of this metric to indicate seagrass abundance. Historical seagrass abundances in older samples from all cores were then studied with the percentage of seagrass-associated benthic foraminifera. Larger changes in seagrass abundance over the past 120 years mostly correspond to known natural and anthropogenic events. The data suggest that the seagrass abundance at Trout Cove, nearest the mainland, was relatively low with minor fluctuations, probably due to the low-salinity conditions that adversely affect the growth of seagrass, which prefers a normal marine environment. Seagrass abundance showed similar oscillations among sites 
within the central bay, which is least influenced by exchange with the Gulf of Mexico and natural and human events on the mainland (Bob Allen Bank and Russell Key). The data indicate three major drops in seagrass abundance during the periods of 1910-1920, 19351945 and 1950-1960. These three obvious decreases were most likely related to the construction of the Flagler Railroad during 1905-1912, and the hypersalinity due to multiyear droughts during the early 1940s and the middle 1950s, respectively. Between 1910 and 1920, seagrass abundance slightly decreased with a smaller magnitude at Ninemile Bank, which is near the Gulf of Mexico, than at Bob Allen and Russell Key, suggesting that the western bay was also affected by construction of the Flagler Railroad. If Ninemile Bank's extremely high value at $\sim 1920$ is considered an anomalous outlier, seagrass abundance would show a gradually decreasing trend since $\sim 1908$, suggesting a continuing effect of this construction. A discriminant analysis showed that the central bay samples of sediments deposited in the periods before vs. after human settlement have similar highs and lows, showing no large changeover between these intervals. However, these intervals are well differentiated within the Ninemile Bank and Trout Cove samples, indicating their sensitivity to less localized, more long-term changes. On a longer time scale, seagrass at Ninemile Bank was seen to appear around 3800-3530 years ago during the initial marine flooding, and gradually increase in abundance until the early 1900s. The reason that seagrass beds became denser overall as indicated by the data may be attributed to the rising sea level, since seagrass prefers normal marine conditions. (2) Salinity. Benthic foraminifera were assigned to two salinity-related groups, a brackish fauna and a marine fauna, based on the species' known preferences. The percentage of the marine fauna at Ninemile Bank in the western bay and Trout Cove in 
the northeastern bay behaved differently from each other and from Bob Allen Bank and Russell Key in the central bay. Trout Cove is next to the mainland and receives more freshwater input from the Everglades, and benthic foraminiferal assemblages have been dominated by the brackish fauna over the last $\sim 1200$ years. Ninemile Bank, located farthest from the mainland, has been less affected by anthropogenic activities such as construction of canals, levees and water retention areas on the mainland and keys. At Ninemile Bank, the salinity was higher before 1930 and was greatly reduced thereafter. Neither the brackish fauna nor the marine fauna dominated the foraminiferal assemblages for long time intervals except for a short period around the end of the 1980s. The changes in benthic foraminiferal assemblages at Bob Allen Bank and Russell Key suggest greater variations in salinity in the central bay over the past 120 years. These changes correspond in time and pattern to the construction of the Flagler Railroad, canals and levees during the last century. On the scale of $\sim 4000$ years, benthic foraminiferal assemblages at Ninemile Bank clearly show that marine water entered the area that is now western Florida Bay before B.P. 3800-3530. Since then, salinity has fluctuated, and the changes include two large drops. The first drop at approximately B.P. 3360-2340 supports a previous hypothesis of sea level fall. Although there was a second drop around 1940, after which salinity remained low, the marine fauna was more abundant than the brackish fauna, indicating a marine environment with salinity above $30 \mathrm{psu}$.

(3) General habitat. Changes in the foraminiferal assemblages as a whole over time reflect changes in habitat. At Bob Allen Bank, Russell Key and Trout Cove, changes over the last $\sim 120$ years are attributed to habitat changes primarily caused by the recent anthropogenic and natural events mentioned above. The most distinctive changes in 
habitat occurred around 1910,1930s-1940s and the end of the 1980s. These habitat changes were most likely caused by the construction of the Flagler Railroad and canals and levees, multiyear droughts, and the recent (1987-1994) seagrass dieoff. Longer term changes in benthic foraminiferal assemblages over the past 4000 years reflect changes in sea level and its related effects on the location of the shoreline. The data suggest that at about $\sim 4000$ years ago the western bay in the area of Ninemile Bank was a mangrove swamp similar to present-day conditions at Trout Cove. A foraminiferal assemblage from around $\sim 3000$ years ago supports a previous hypothesis of a period of sea level fall. The Ninemile Bank assemblages indicate a more organic-rich, lower oxygen habitat between 1932 and 2001, possibly related to the long term oxidation of organic matter in the western portions of Florida Bay following construction of the Flagler Railroad from Miami to Key West. 


\section{PLATES}

Plate 1

Abundant benthic foraminifera of Florida Bay. Scale bar $=0.5 \mathrm{~mm}$

1-2 Ammonia beccarii (Linnaeus), 1772 (Core \#0208134, 236-238 cm)

3 Elphidium galvestonense Kornfeld, 1931 (Core \#0208134, 236-238 cm)

4 Elphidium poeyanum (d'Orbigny), 1839 (Core \#0208134, 236-238 cm)

5-6 Elphidium mexicanum Kornfeld, 1931 (Core \#0208134, 236-238 cm)

7-8 Haynesina depressula (Walker and Jacob), 1789 (Core \#0208134, 236-238 cm)

9-10 Rosalina floridana (Cushman), 1922 (Core \#0206122, 2-4 cm)

11-12 Nonionella atlantica Cushman, 1947 (Core \#0206125, 4-6 cm)

13-14 Peneroplis bradyi Cushman, 1930 (Core \#0205124, 36-38 cm)

15-16 Archaias angulatus (Fichtel and Moll), 1803 (Core \#02061211, 12-14 cm) 


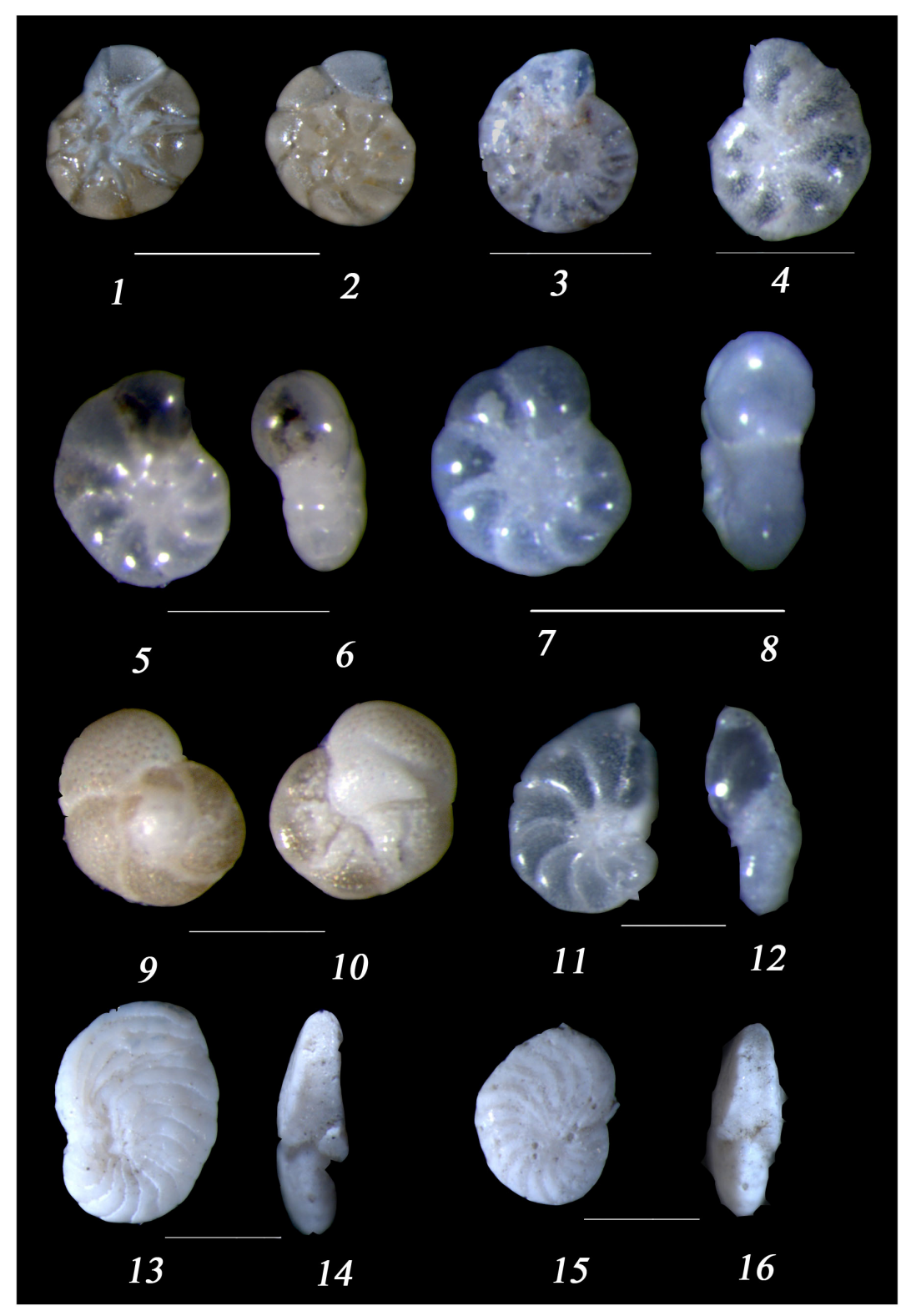

Plate 1 
Plate 2

Abundant benthic foraminifera of Florida Bay. Scale bar $=0.5 \mathrm{~mm}$

1-2 Biloculina eburnea (d'Orbigny), 1839 (Core \#0206124, 0-2 cm)

3-4 Quinqueloculina bosciana d'Orbigny, 1839 (Core \#0206122, 0-2 cm)

5-6 Quinqueloculina impressa Reuss, 1851 (Core \#0206122, 0-2 cm)

7-8 Quinqueloculina poeyana d'Orbigny, 1839 (Core \#0206122, 0-2 cm)

9-10 Quinqueloculina polygona d'Orbigny, 1839 (Core \#0206122, 0-2 cm)

11-12 Quinqueloculina subpoeyana Cushman, 1922 (Core \#0206122, 0-2 cm)

13 Heterillina cribrostoma (Heron-Allen and Earland), 1915 (Core \#0206122, 0-2 cm)

14-15 Pateoris dilatata (d'Orbigny), 1839 (Core \#0208134, 16-18 cm) 


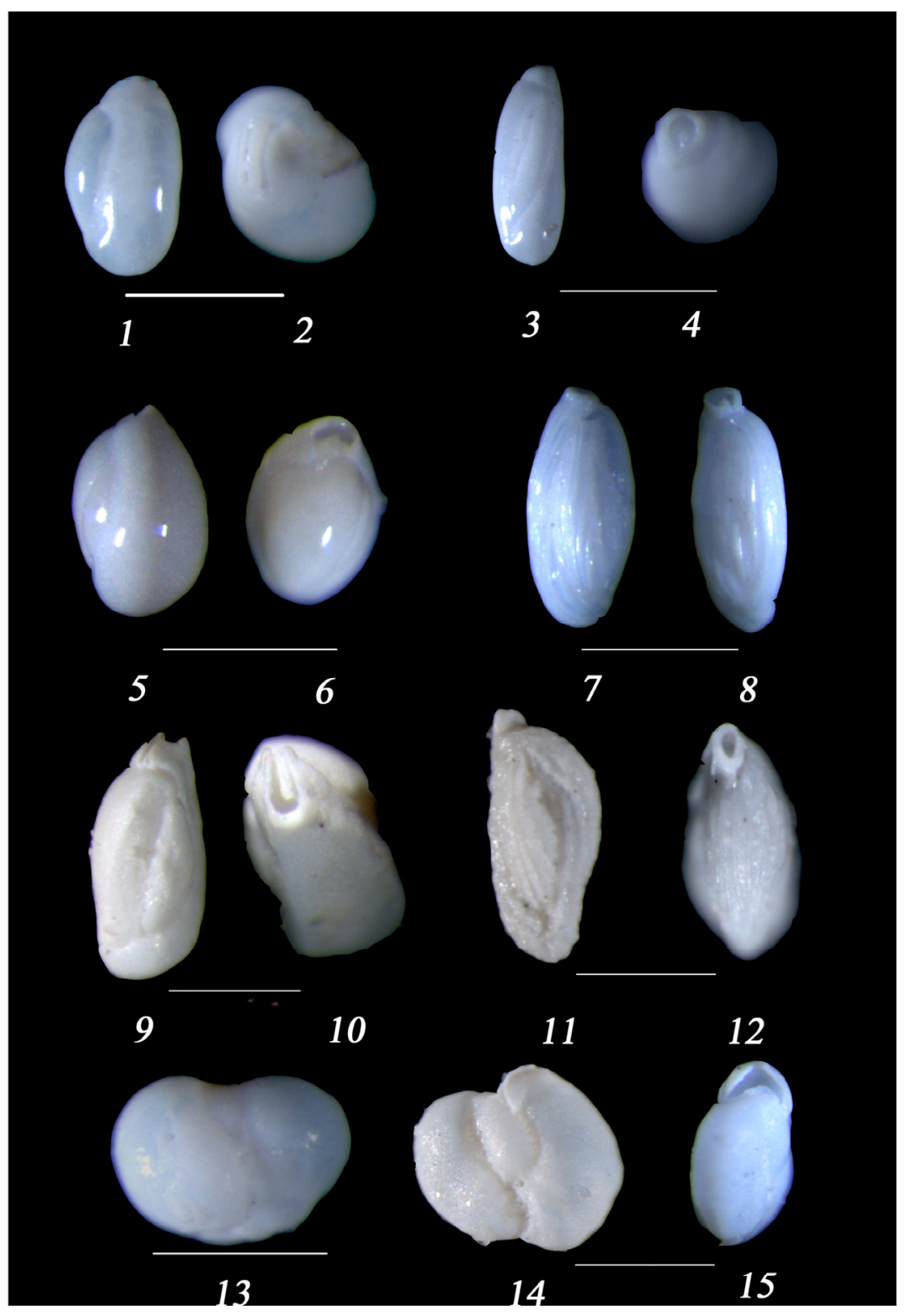

Plate 2 
Plate 3

Abundant benthic foraminifera of Florida Bay. Scale bar $=0.5 \mathrm{~mm}$

1-2 Triloculina bicarinata d'Orbigny, 1839a (Core \#0206122, 10-12 cm)

3-4 Triloculina fiterrei Acosta, 1940 (Core \#0206122, 10-12 cm)

5-6 Triloculina rotunda d'Orbigny, 1826 (Core \#0206127, 12-14 cm)

7 Ammobaculites exiguus Cushman and Bronnimann, 1948 (Core \#0206134, 22-24 cm)

8 Articulina mucronata (d'Orbigny), 1839a (Core \#02061211, 10-12 cm; red color of test from rose Bengal stain for protoplasm).

9 Bolivina lanceolata Parker, 1954 (Core \#0206122, 4-6 cm)

10 Bolivina lowmani Phleger and Parker, 1951 (Core \#0208134, 22-24 cm)

11 Buliminella elegantissima d'Orbigny, 1839b (Core \#0208134, 42-44 cm)

12 Sorites marginalis (Lamarck), 1816 (Core \#0206125, 6-8 cm; red color of test from rose Bengal stain for protoplasm) 


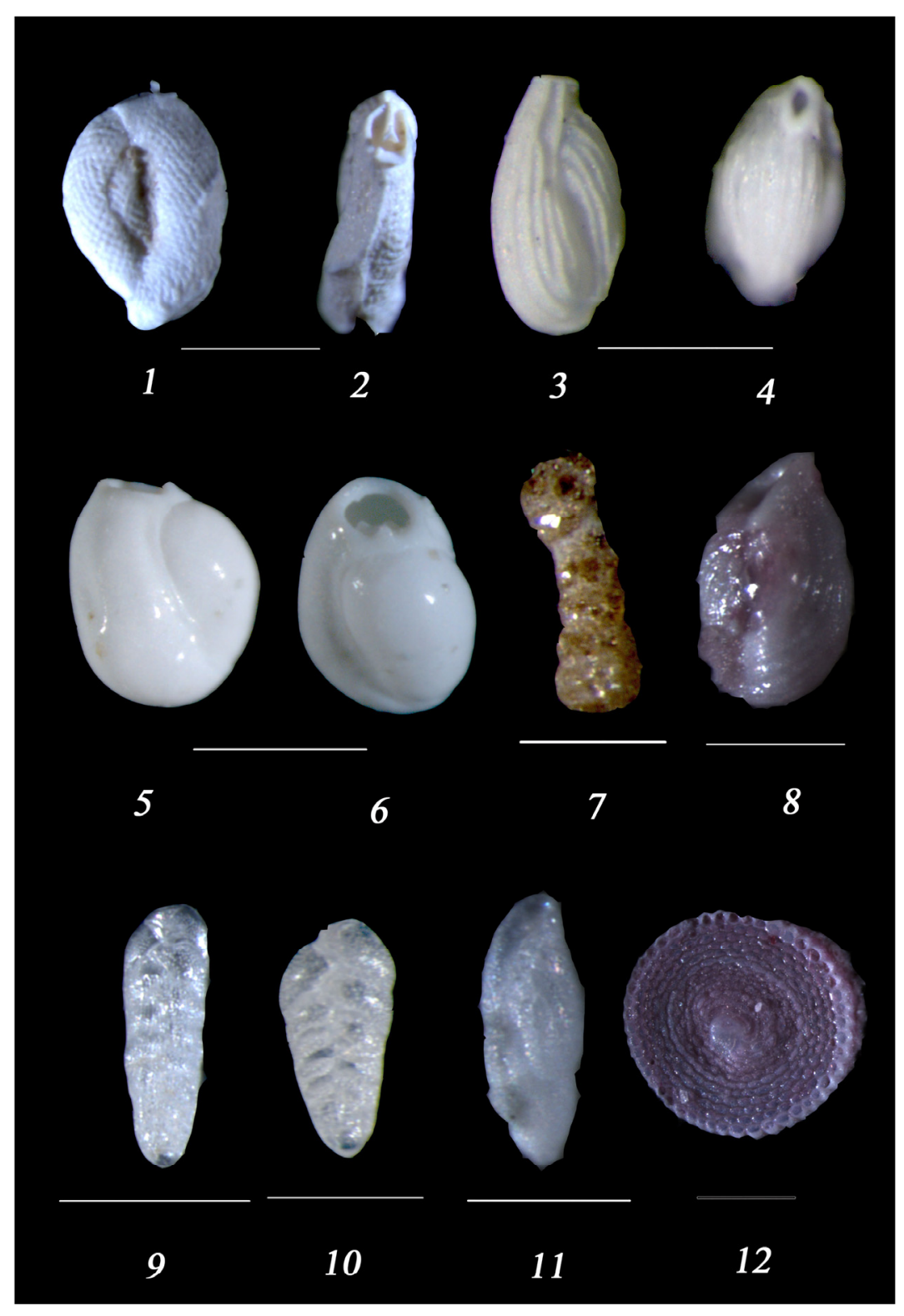

Plate 3 


\section{APPENDIX 1.}

Species identified in the six cores from Florida Bay. Name in brackets is original genus.

Ammobaculites exiguus Cushman and Bronnimann, 1948

Ammonia beccarii (Linnaeus), 1772 [Nautilus]

Archaias angulatus (Fichtel and Moll), 1803 [Nautilus]

Articulina mucronata (d'Orbigny), 1839a [Vertebralina]

Biloculina eburnea (d'Orbigny), 1839a [Triloculina]

Biloculina globosa (Bornemann), 1855 [Fissurina]

Bolivina inflata Heron-Allen and Earland, 1913

Bolivina lanceolata Parker, 1954

Bulimina elegantissima d'Orbigny, 1839b

Cancris sagra (d'Orbigny), 1839a [Rotalina (Rotalina)]

Clavulina tricarinata d'Orbigny, 1839a

Cyclogyra involvens (Reuss), 1850 [Operculina]

Discorbis mira Cushman, 1922

Elphidium galvestonense Kornfeld, 1931

Elphidium mexicanum Kornfeld, 1931 [E. incertum (Williamson) var. mexicanum]

Elphidium poeyanum (d'Orbigny), 1839a [Polystomella]

Elphidium sagrum (d'Orbigny), 1839a [Polystomella]

Fursenkoina pontoni (Cushman), 1932 [Virgulina]

Gaudryina exilis Cushman and Bronnimann, 1948

Haynesina depressula (Walker and Jacob), 1789 [Nautilus]

Heterillina cribrostoma (Heron-Allen and Earland), 1915 [Miliolina] 
Massilina protea Parker, 1953

Miliolinella fichteliana (d'Orbigny), 1839a [Triloculina]

Miliolinella oblonga (Montagu), 1803 [Vermiculum]

Nonionella atlantica Cushman, 1947

Nonionina grateloupi d'Orbigny, 1839a

Pateoris dilatata (d'Orbigny), 1839a [Quinqueloculina]

Peneroplis bradyi Cushman, 1930

Peneroplis proteus d'Orbigny, 1839a

Protelphidium delicatulum (Bermudez), 1949 [Elphidium]

Pyrgo elongata (d'Orbigny), 1826 [Biloculina]

Pyrulina cylindroides (Roemer), 1838 [Polymorphina]

Quinqueloculina agglutinans d'Orbigny, 1839a

Quinqueloculina angulatus (Williamson), 1858 [Miliolina]

Quinqueloculina bicarinata d'Orbigny, 1826

Quinqueloculina bicornis (Walker and Jacob), 1798 [Serpula]

Quinqueloculina bidentata d'Orbigny, 1839a

Quinqueloculina bosciana d'Orbigny, 1839a

Quinqueloculina candeiana d'Orbigny, 1839a

Quinqueloculina compta Cushman, 1947

Quinqueloculina goesi d'Orbigny, 1839a

Quinqueloculina impressa Reuss, 1851

Quinqueloculina laevigata d'Orbigny, 1826

Quinqueloculina lamarckiana d'Orbigny, 1839a 
Quinqueloculina planciana d'Orbigny, 1839a

Quinqueloculina poeyana d'Orbigny, 1839a

Quinqueloculina polygona d'Orbigny, 1839a

Quinqueloculina seminulum (Linnaeus), 1758 [Serpula]

Quinqueloculina striata Deshayes, 1833

Quinqueloculina subpoeyana Cushman, 1922

Quinqueloculina tenagos Parker 1962

Quinqueloculina akneriana d'Orbigny, 1846

Rosalina floridana (Cushman), 1922 [Discorbis]

Rosalina floridensis (Cushman), 1930 [Discorbis bertheloti (d'Orbigny) var. floridensis]

Spirillina obconica Brady, 1879

Spirillina vivipara Ehrenberg, 1843

Spiroloculina communis Cushman and Todd, 1944

Spiroloculina eximia Cushman, 1922

Trifarina bella (Phleger and Parker), 1951 [Angulogerina]

Triloculina linneiana d'Orbigny, 1839a

Triloculina bassensis Parr, 1945

Triloculina bicarinata d'Orbigny, 1839a

Triloculina gracilis d'Orbigny, 1839a

Triloculina rotunda d'Orbigny, 1826

Triloculina trigonula (Lamarck), 1804 [Miliolites]

Triloculina fiterrei Acosta, 1940 
VITA

JIE CHENG

November 3, 1979

Born, Jingzhou, Hubei, China

B.A., Biology,

Nankai University

Tianjin, P.R. China

2003-2010

Doctoral Candidate in Geosciences

Florida International University

Miami, FL

2003-2004

Research Assitant of the Year Award

Florida International University

Miami, FL

2004-2008

Teaching Assistant of the Year Award

Florida International University

Miami, FL

2008-2009

Dissertation Year Fellowship Award

Florida International University

Miami, FL

\section{PUBLICATIONS AND PRESENTATIONS}

Cheng, J., and Collins, L., 2008, Using benthic foraminifera to understand seagrass

abundance, salinity and sea-level variation in Florida Bay, Geological Society of America, Houston, TX, USA.

Cheng, J., and Collins, L., 2008, Foraminifera, a powerful proxy to indicate sea level

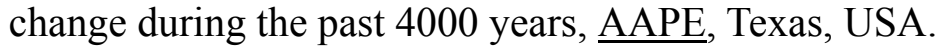

Cheng, J., and Collins, L., 2009, Environmental changes in Florida Bay over the past 100 years by using benthic foraminifer, Young Earth-Scientists Congress, China.

Cheng, J., and Collins, L., and Holmes, C., 2010, Paleoecology of Florida Bay over the past 4,000 years, Journal of Foraminifera, in preparation.

Cheng, J., and Collins, L., 2010, Relationships between frequent hurricanes and salinity variation in Florida Bay, Paleoecology, Paleoenvironment \& Paleochemistry, in preparation. 
Collins, L., and Cheng, J., 2010, Changes in water quality of Florida Bay: using seagrass abundance as an indicator, Environmental Marine Research, in preparation. 